\title{
Gert Oostindie \&
}

\section{Inge Klinkers}

\section{DECOLONISING THE}

\section{CARIBBEAN}

Dutch Policies in a

\section{Comparative Perspective}

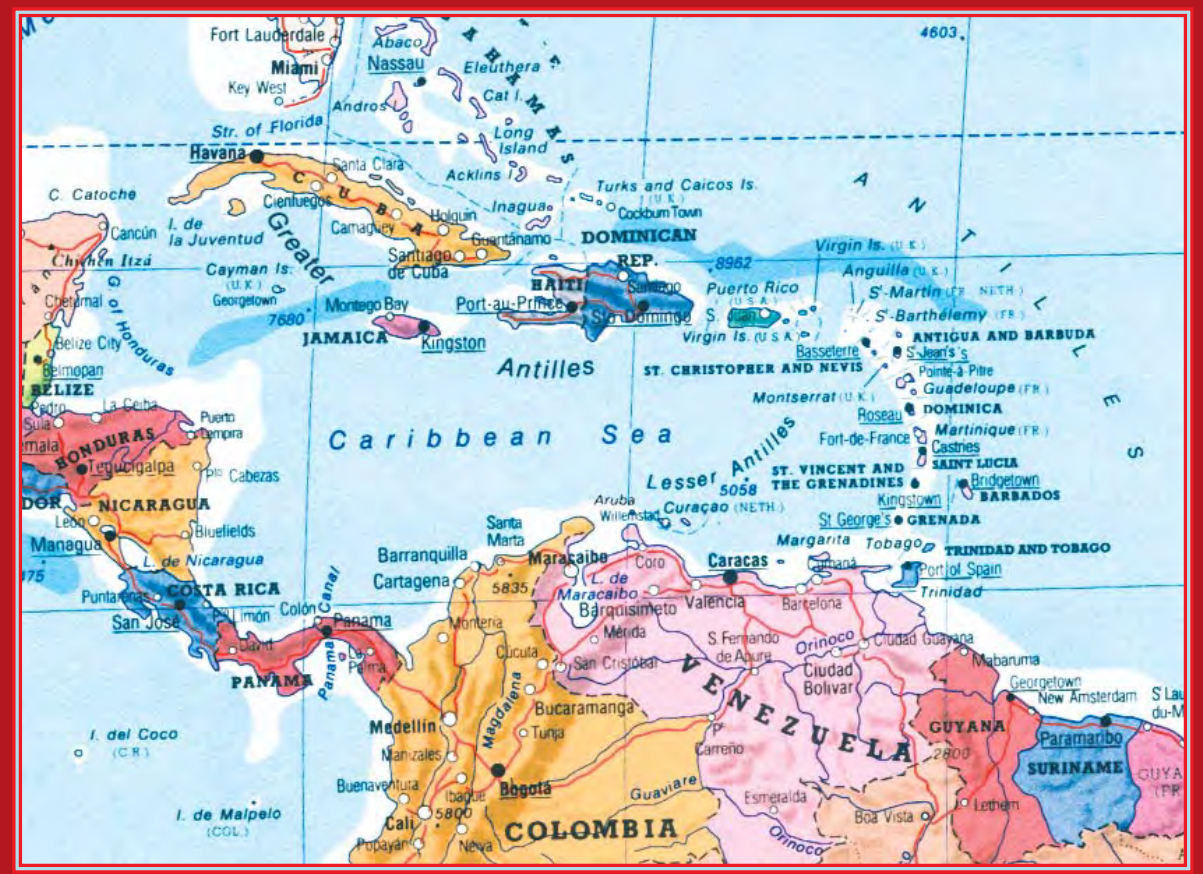


Decolonising the Caribbean 



\title{
Decolonising \\ the Caribbean
}

\author{
Dutch Policies \\ in a Comparative \\ Perspective
}

Gert Oostindie \& Inge Klinkers

Amsterdam University Press 
Cover map: the borders between the various countries in the Guyanas are disputed. The present map does not express the judgement of all countries involved, nor of the authors.

Cover design and lay-out: Hannie Pijnappels, Amsterdam

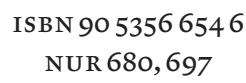

(c) Amsterdam University Press, Amsterdam, 2003

\begin{abstract}
All rights reserved. Without limiting the rights under copyright reserved above, no part of this book may be reproduced, stored in or introduced into a retrieval system, or transmitted, in any form or by any means (electronic, mechanical, photocopying, recording or otherwise) without the written permission of both the copyright owner and the author of the book.
\end{abstract}




\title{
Table of Contents
}

\author{
Acknowledgements -7 \\ Introduction -9
}

1. The Comparative Context: Fragmentation of the British

West Indies and the Remnants of Empire -17

The Colonial Period - 17

The Failure of the West Indian Federation - 20

Re-engagement: The Overseas Territories -24

2. The Comparative Context: The French départements

d'outre-mer, Grandeur and Civilisation at a Price -29

The Colonial Period - 30

Decolonisation through Integration -32

Assimilation à la française- 36

3. The Comparative Context: Puerto Rico and

the U.s. Virgin Islands, Deadlocks in American Geopolitics - 42

The Commonwealth of Puerto Rico-43

Puerto Rico's Status Debate -48

The u.s. Virgin Islands: Unincorporated Territory -53

4. Dutch Rule in the Caribbean up until 1940:

Careless Colonialism -57

Failed Exploitation -57

Colonial Administration -60

Cultural Divides -62

5. The Dismantling of the Dutch Empire, 1940-1954-64

World War II, Powerless Dutch Colonialism and

the Atlantic Charter -65

In the Shadow of Indonesia- 69

The Round-Table Conferences -76

The Charter of the Kingdom of the Netherlands, 1954-84

6. The Failed Attempt at Model Decolonisation, 1954-1975-89

Exploring the Charter's Margins -92

Turning Point: The 1969 Curaçao Revolt -96 
Negotiating the Independence of Suriname-102

The Antillean Refusal-116

7. The Perpetuation of the Transatlantic Kingdom since 1975-118

The Aruban Status Aparte-121

A New Dutch Agenda for the 1990s-131

Deadlocks and the Margins of Autonomy-140

Into the Twenty-First Century-145

8. Illusions and Benefits of 'Reciprocal Assistance':

Development Aid -153

Towards Structural Aid, 1954-1975-157

Aid to the Antilles and Aruba since 1975: Structural or Finite? -163

A Comparative Perspective -172

\section{A Caribbean Exodus-177}

Prelude, 1954-1973-180

The Independence of Suriname and the Exodus, 1973-1980-183

The Antillean Exodus of the 1990s - 189

A Comparative Perspective-194

10. Cultural Exchange, Proximity and Distance-201

Dutch Passport, Dutch Language? - 202

Reciprocal Cultural Exchange? - 207

A Comparative Perspective -212

11. Epilogue-215

Dutch Caribbean Decolonisation in a Nutshell-217

Caribbean Decolonisation: a Tentative Balance Sheet -220

What Kind of Kingdom? -224

The Future -229

Notes -234

Bibliography -270

Indexes-284 


\section{Acknowledgements}

This book concludes the research which began in 1995, and which culminated in the PhD thesis by Inge Klinkers De weg naar het Statuut (1999), our three-volume Knellende Koninkrijksbanden (2001), and its abridged version, Het Koninkrijk in de Caraïben (2001). We would like to acknowledge the support of the institutions which enabled the research and writing of Knellende Koninkrijksbanden: the Dutch Ministry of the Interior and Kingdom Affairs, the KITLV/Royal Institute of Southeast Asian and Caribbean Studies in Leiden, and our then advisory board consisting of, in alphabetical order, the late Jnan Adhin, Mito Croes, Carel de Haseth, Ernst Hirsch Ballin (chair), and Harry Hoetink. ${ }^{1}$ We mention with deep gratitude the over sixty protagonists we interviewed from all four countries involved.

The writing of Decolonising the Caribbean entailed more research, more interviews and a great deal of discussion. We thank Marcel Cramwinckel, Pitou van Dijck, Carel de Haseth, Richard Price and Gijs de Vries for their helpful comments on earlier drafts of various chapters. ${ }^{2}$ The comments of the protagonists of the most recent history were at times diametrically opposed. We have attempted to give a proper perspective of their views. It goes without saying that ultimate responsibility for the facts and analyses presented in this book remains with the authors. With heartfelt thanks we acknowledge the editorial support of Maggi West, who helped iron out the English that went Dutch. Knellende Koninkrijksbanden and Het Koninkrijk in de Caraïben were published with great care and enthusiasm by Amsterdam University Press. We are delighted to publish this final piece once again with Aup. We owe many thanks to the Press' tenacious director, Saskia de Vries. 



\section{Introduction}

For over two centuries much of the Caribbean has been embroiled in heated, and initially violent, decolonisation. One may well date the beginnings of the process to the first recorded retreats of European colonisers, the conclusion of the eighteenth century peace treaties between the British and the Maroons of Jamaica, and then between the Dutch and the Maroons of Suriname - struggles for freedom which were, however, inconsequential in post-colonial history. So, Caribbean decolonisation formally began with the 1791 Haitian Revolution. With this seminal event came the dawning of a new era. Constitutional sovereignty was subsequently secured by the Dominican Republic (1844) and at the start of the twentieth century by Cuba (1901). Both were late in securing sovereignty by Latin American standards.

Whereas the three most populated Caribbean countries had now gained independence, the rest of the region remained firmly locked within colonialism, either dependent on the traditional metropolitan powers, the United Kingdom, France and the Netherlands, or usurped by the ascending power of the United States. At the outbreak of World War II most Caribbean territories were still bound in colonial tutelage.

A new wave of decolonisation swept the region in the 1960 and 1970 . Today most of the Caribbean is sovereign and some 85 per cent of the 37 million Caribbean people live in independent countries. However, it appears that independence was achieved at a high price. In general terms, standards of living in the non-sovereign Caribbean are significantly higher than they are in the independent countries. Furthermore, in a region that has witnessed many dictatorial regimes and territorial disputes, and which now faces the contemporary challenges of international crime, the remaining non-sovereign territories still continue to enjoy a higher degree of security and stability. Small wonder then that the urge for independence in these territories is weak, and indeed it seems that Caribbean decolonisation may well have reached its final dénouement with the present status quo.

As a result of this 'unfinished' decolonisation, a little over five million Caribbean citizens are living in one of the four non-sovereign parts of the region. The overwhelming majority of these are Puerto Ricans (3.8 million). The population figures for the other territories are much lower. The three French départements d'outre-mer harbour almost one million inhabitants, the Netherlands Antilles and Aruba nearly 270,000, the British Caribbean Overseas Territories 155,000 and the U.s. Virgin Islands 110,000. These five million residents live under divergent post-colonial arrangements. In view 
of the diversity in approach by the other colonisers, it is necessary in the opening chapters to outline these in order to give context to Dutch postwar decolonisation policy. Metropolitan policies mainly conditioned decolonisation, as will become clear from the following; yet in the British and Dutch cases Caribbean obstruction successfully blocked the effort to accomplish a full retreat.

Much has been written on the post-war decolonisation in the Caribbean, but rarely from a truly comparative perspective, and - apart from Dutchlanguage studies - seldom with serious attention to the former Dutch colonies of Suriname, the Netherlands Antilles and Aruba. The aim of the present study is to help bridge these gaps. ${ }^{1}$

Based on our recently published comprehensive 17oo-page study, Knellende Koninkrijksbanden - 'Restrictive Kingdom Ties' - we aim to present a succinct history of Dutch decolonisation policy since $1940 .^{2}$ World War II marks the starting point. As a result of the war, somewhat reluctantly, Dutch decolonisation finally began to gain momentum, in line with the other metropolitan powers and their colonies around the world. Pressed by developments in Indonesia - where, unlike in Suriname and the Netherlands Antilles, the pro-independence movement was strong - the Dutch offered the prospect of a large measure of autonomy to the erstwhile colonial subjects. For Indonesia this was too little, too late. In August 1945 the nationalists proclaimed independence; only in December 1949 did the Dutch unwillingly transfer sovereignty to the Republic. Five years later the pledge of autonomy - actually, as we will argue, the result of an unsuccessful policy aimed at keeping Indonesia within the Kingdom - was implemented for the West Indies with the 1954 Statuut or 'Charter for the Kingdom of the Netherlands'. This Charter remains intact, virtually unaltered, as the Constitution of the Kingdom. The one significant change has been in its membership: Suriname opted out in 1975 and one of the Antillean islands, Aruba, became a separate nation within the Kingdom in 1986.

To put Dutch policy into context, we will discuss in some depth Dutch decolonisation policies with regard to the far more important colony of Indonesia, as well as significant changes within Dutch society and politics which helped shape the governmental role towards the Caribbean territories. We will emphasise that while Indonesia was perceived to be of utmost importance to the Netherlands, and therefore attracted much heated attention in Dutch society and politics, this was rarely the case with respect to the Caribbean territories. These former colonies had little economic significance to the metropolis, and this would remain the case. As for geopolitics, after the loss of Indonesia the Dutch had lost any desire to be a world player in territorial terms. While The Hague did not feel the Caribbean to be of much importance, the conspicuous asymmetry between the metropolis and the remaining overseas territories of the Kingdom did not fail to leave 
an enduring mark on these relations, bringing along a perpetual legacy of ambivalent Caribbean dependency.

This book also compares and contrasts the Dutch 'model' with the goals and strategies that shaped the decolonisation policies of the three other twenty-first century post-colonial powers in the Caribbean: the United Kingdom, France and the United States. The comparative aspects of this book draw heavily on the $\mathrm{PhD}$ thesis De weg naar het Statuut - 'The Road to the Charter of the Kingdom of the Netherlands' by Inge Klinkers (1999). This has been brought up-to-date with further research.

At the outbreak of World War II, statesmen from these countries came to realise the profound impact of the war on their overseas territories. Meanwhile, emerging nationalism in the Caribbean colonies nurtured high expectations of autonomy, or full sovereignty, implying a conviction that the colonial era had to become a thing of the past. With respect to their Caribbean dependencies, each of the metropolitan countries followed its own path, sometimes with correlating outcomes, but more often with widely divergent results.

British policy was clear and consistent. No longer interested in maintaining a presence in its economically marginal West Indies, the United Kingdom strived for a complete and early transfer of sovereignty. As the initial project of a West Indian Federation collapsed in 1962, Westminster began to confer independence to its colonies on an individual basis, starting with the larger ones. Much to the annoyance of the British, this process came to a halt in the 1980s, hence today's remaining British Overseas Territories. No major economic assistance was offered to the new Commonwealth nations and only limited aid to the remaining dependencies. In addition, the right of British Caribbean citizens to settle in the United Kingdom was withdrawn in the early 1960s. In a sense then, the practical advantages to the West Indian territories of remaining under British sovereignty were modest. This situation has since been redressed to some degree with the restoration of British citizenship in May 2002.

Both the United States and France opted for a policy of continued presence in the Caribbean. This contrast to the British posture is remarkable, bearing in mind that for all of these metropolitan powers the Caribbean counted for little in an economic perspective. The answer to why they remained is to be found in geopolitics. The strategic reasoning behind Washington's policy is clear, taking into consideration the Puerto Rican and U.s. Virgin Islands' location in America's Caribbean 'back yard', this being particularly important in a pre-1990s Cold War context. The French policy must be interpreted with regard to its post-war attempt to retain its traditional role in international politics, hence preserving some of its grandeur and international influence of the colonial past. Unlike the United Kingdom, both Washington and France have been prepared to uphold their policies by spending relatively large amounts of money on their Caribbean 
territories. In addition, their borders have never been closed to citizens from these dependencies.

The outlines of the three metropolitan policies are discussed in the opening chapters, thus providing a context to the subsequent analysis of Dutch policies. The Hague, as it will become clear in following chapters, initially opted for a model of continued presence in the Caribbean, regardless of an underlying feeling that this was of little importance to the Netherlands itself. By 1970, The Hague switched policy, aiming at a quick transfer of sovereignty, a target accomplished for Suriname in 1975, but not for the Netherlands Antilles.

In later thematic chapters dedicated to Dutch policies for economic development, migration and culture, we include brief comparative excursions into the policies deployed by the other three remaining metropolitan powers. In the Epilogue we propose a theoretical framework for evaluating distinguishing features, as well as accomplishments and failures within the four approaches to decolonisation. Effects of the four models are compared on the basis of the following sets of criteria: constitutional goals and results (the distribution of legal and administrative powers); migration policies (nationality and right of abode); economic policies (costs and benefits); and cultural policies and national identity. The effects are considered from the perspective of both the 'mother countries' and the dependent territories. The intention is to classify, compare and evaluate the characteristics of the different constitutional models in a more systematic way than has previously been undertaken. This comparison does not include the development of bilateral relations between a metropolis and a former colony in those cases where political independence has been attained. For example, neither the development of Suriname since 1975 and its relations with the Netherlands since that year, nor the record of independent Barbados and Barbadian-British relations since 1966 are dealt with in this book.

The Epilogue concludes with a discussion on the future of the Dutch Kingdom against the background of the present, increasingly intensive and mutually restrictive transatlantic ties. On this basis we explain why the Charter of the Kingdom, initially introduced as a 'non-permanent' pact, has continued to exist virtually unaltered for half a century; we also suggest that it is unlikely to remain this way.

Unlike Knellende Koninkrijksbanden, the present study does not discuss Dutch Caribbean policies against the backdrop of the overall development of Dutch politics and administration in any detail. A few general observations suffice to introduce the reader to the relevant background events.

The Netherlands has been a Kingdom since 1813. While the constitutional role of the King was decisively curtailed with the establishment of a parliamentary democracy in 1848 , the Royal Family continued to have an appreciable influence on state policies, and in particular colonial policies, 
well into the twentieth century. Evidence of this is visible in the remarkably influential - and distinctly conservative - role played by Queen Wilhelmina in the immediate post-war decolonisation process. Under her successor Juliana, royal influence within Dutch politics waned, and even if it is often stated that the present Queen Beatrix recovered some of this lost ground, there is no doubting the supremacy of parliament. In post-colonial Dutch relations, the importance of the House of Orange - although ceremonial in nature - is essential in the maintenance of good relations within the Kingdom. In fact, recent research indicates that for Antilleans and Arubans, the Royal Family has far more emotional appeal than the Dutch political leadership. Incidentally, perhaps this may even still be said of Suriname, once reputedly the most 'Orange' of all colonies. ${ }^{3}$

At the outbreak of World War II, a broad-based Dutch war cabinet was established in London, composed of ministers of various political backgrounds and headed by a Christian democratic prime minister. After the war, Dutch politics continued to be dominated by the Christian democratic parties until the 199os. From a comfortable position in the centre of the political spectrum, they governed either with the social democratic left (dominated by the Labour Party, PvdA), or with the conservative liberals (vvD). This resulted in a continuous alternation between centre-left and centreright administrations. ${ }^{4}$ In the 199 os the pivotal position of the major Christian democratic parties, organised in the CDA, was broken by two successive 'purple' cabinets of PvdA, vvD, and an intermediate left-liberal party D66. However, since 2002, the Christian democrats have regained their rewarding centre position once more. ${ }^{5}$

Dutch politics has often been analysed in terms of 'consociational democracy'. With a parliament composed of many parties, finding a majority usually necessitates carefully constructed coalitions. This distinctive feature, some may say, fits well into a general Dutch inclination of gravitating towards the centre rather than searching for extremes. In fact, the 'purple' coalitions of the 1990 s originated more from a mutual dislike among social democrats and conservative liberals with the apparently perennial centre stage occupied by the Christian democrats, than with a longing for a fundamental change of policy. Looking back at sixty years of politics in the Netherlands, consensus rather than polarisation becomes apparent. Arguably the most radical cabinet was that of the centre-left under Prime Minister Joop den Uyl (PvdA) in the mid-197os. One may well dispute whether this cabinet left any significant legacy in Dutch politics. In the context of this study, the cabinet of den Uyl most certainly made a crucial and ideologically-inspired difference when it successfully accomplished the transfer of sovereignty to Suriname.

While this break fitted within a new political paradigm, as will be discussed at length, in general terms Dutch party politics have been largely irrelevant with regard to metropolitan policies involving the Caribbean ter- 
ritories. Since the 1950s, defining and executing policy was the prerogative of one cabinet member. This member of government - always a man and, remarkably, rarely a social democrat - was only incidentally seconded by his prime minister, again the exception being the 1974-1977 cabinet of den Uyl. $^{6}$ Dutch parliament, along with the few specialists engaged with Caribbean affairs, has tended to follow rather than steer whatever debate there was going on, again with the exclusion of the first half of the 1970s. In summary, therefore, there will be little need in the present study to discuss the development of Dutch politics in much detail. As far as its Caribbean policies are concerned, 'The Hague' has been a rather monolithic entity. This, in turn, can be explained not only by Dutch consensus on policies to be pursued but also, and even more so, by the marginal importance of this portfolio in Dutch politics.

Knellende Koninkrijksbanden was the result of a research project commissioned by the Dutch government. After completion of the text in 2000, a controversy between the government and the authors over the use of confidential governmental papers resulted in a prolonged case of stalemate which was only resolved the following year. In the end, we had to admit to some concessions in terms of the presentation of our findings derived from cabinet meetings during the 1980 and 1990 . In particular, the quoting of remarks made by identifiable cabinet members was prohibited. However, our analysis and criticism of Dutch policy were not at issue and remained unaffected.

Even so this conflict, which attracted much media attention, served as a reminder that any study commissioned by a government - or political party, or corporate company for that matter - is bound to elicit questions as to the independent status of its authors and its outcome. A few words on our perspective as developed in Knellende Koninkrijksbanden and now in Decolonising the Caribbean are therefore requisite. This being a study of Dutch policy in a comparative perspective, does not implicate an identification with the Netherlands, but it does imply a conscious narrowing of our focus. Antillean, Aruban and Surinamese policy making, as well as developments within these Caribbean societies, is only discussed indirectly, as factors which were, or should have been, dealt with in Dutch policy making. In that sense our focus is fairly narrow. This limitation becomes most apparent in the use of governmental records, which derive mainly from Dutch metropolitan sources. Only through the conducting of interviews and our reference to relevant scholarly literature have we sought to highlight Caribbean perspectives - even though here too, we were mainly interested in establishing opinions on Dutch policy in the past decades.

Since Knellende Koninkrijksbanden and its popularised version Het Koninkrijk in de Caraïben were published in late 2001, we have presented and discussed our findings on many occasions, both in the Netherlands and in its 
former Caribbean colonies. As was to be expected, emotions sometimes ran high among the predominantly Caribbean audiences - whether in Suriname, the Antilles and Aruba or in Caribbean centres within the Netherlands. In a sense, this only confirms our conclusion that this portfolio inevitably has far more significance on the Caribbean side of the asymmetrical relationship than it has on the Dutch side. Yet one may be more specific. Our conclusion that the Caribbean colonies were decolonised in an environment where The Hague soon became anxious to sever bonds, provoked diverging responses. On the one hand, acceptance of this conclusion met with a certain bitterness, and on the other hand with almost self-congratulatory reactions. The latter reaction, not surprisingly, was voiced mainly among Antilleans and Arubans, who after all are still within the Kingdom, despite two decades of Dutch insistence on their departure. On justifiable grounds, they interpret the final Dutch acceptance of the Antillean and Aruban permanency within the Kingdom as their victory.

Bitter reactions were more often voiced by the Surinamese, particularly among those Surinamese residing in the Netherlands. We would suggest that in the young Republic, even if many doubts remain as to the benefits of independence, along with an acute awareness of the material advantages that relatives and friends in the Netherlands enjoy, there appears to be a general feeling that history cannot be changed so there is little point harbouring resentment and looking back in anger. Perhaps this indignation among Surinamese in the Netherlands continues to be fuelled by an uneasy feeling of being between two worlds, no longer part of Suriname, yet never unconditionally part of the Netherlands - faced with being Surinamese Dutch rather than simply being Dutch. Among the ideologically inclined, this feeling in turn may well be strengthened by a sense of guilt for abandoning the Republic.

On all sides there have been strong refutations regarding our conclusion which states that, because the Dutch Caribbean was of so little economic and political significance, the Netherlands was happy to part with Suriname, and would have been delighted to break up the transatlantic Kingdom altogether. We maintain that this lack of tangible interest, combined with the perceived high cost inherent in the relationship, resulted in a Dutch policy of withdrawal which has partly succeeded. Others squarely counter that there has always been a hidden agenda of tangible Dutch selfinterest. The argument then runs mainly in economic terms, affirming that actually both the Dutch private sector and government have been benefiting enormously from the Caribbean connection and continue to do so today, even expecting major advantages tomorrow. This, as the clearly nationalist argument runs, explains why the Dutch have continued to hold sway in the Antilles and Aruba. In the same vein, this thesis demonstrates that the independence of Suriname was not - as we suggest - largely the result of a self-interested Dutch policy, but rather a nationalist accomplish- 
ment imposed on the Dutch through courageous nationalist struggle. Yet precious few hard facts support this claim. And it was actually somewhat tragicomic, if not surreal, to hear this claim strongly defended by older Surinamese nationalists who shortly after securing independence settled in the Netherlands with Dutch passports.

This latter observation runs the risk of being interpreted as mere provocation. Yet what we indeed take to be basically a rhetorical strategy rather than a convincing statement of fact, does point back to the criteria we have advanced and will elaborate upon later in this study, with regard to the costs and benefits of independence, and the models of decolonisation employed within the non-sovereign Caribbean. Most of our criteria are fairly tangible, material: passport, economic support, guarantees of territory and human rights and liberties. Yet there is also the criterion of culture and national identity. It is this that the non-sovereign Caribbean territories share with the Caribbean migrants in the various metropolitan centres, an ambivalence which has become irreversibly engrained with their self-sought contemporary status, much in the sense of Cuban nationalist José Marti's famous dictum, of being 'in the belly of the beast'. In the emergence of Caribbean transnational communities and corresponding mixed identities, the story of decolonisation and the accompanying exodus takes centre stage. We realise that it is a moot point whether the kind of analysis proposed in our study is a welcome addition as seen from that perspective. But then again, identities cannot be founded on ideology alone. 


\section{The Comparative Context: Fragmentation of the British West Indies and the Remnants of Empire}

Today the decolonisation process has taken the British back some three hundred years, to the region where they originally began their worldwide colonisation: the Union Jack still flies on many of the islands conquered by the United Kingdom during the first global wave of colonisation in the seventeenth century. These included Barbados, Bermuda, the Bahamas, the Leeward Islands and Jamaica; in the second half of the eighteenth century to be followed by Dominica, St. Kitts-Nevis, Grenada, St. Vincent, Tobago and St. Lucia. Trinidad and British Guiana, seized from France and the Netherlands respectively after the Napoleonic wars, were among some of the latest Caribbean territories to be colonised by the British. ${ }^{1}$ This extensive colonisation history has seen the majority of Caribbean territories adopt English as the main language. ${ }^{2}$ However, the former British West Indies consists of many relatively small territories with equally small populations. Therefore only around one quarter of the total 37 million inhabitants of the Caribbean is English speaking.

\section{The Colonial Period}

According to the British tradition of devolving responsibility from the imperial centre to the colonies, more or less the whole region was granted a fairly high degree of local autonomy up until the last quarter of the nineteenth century. This old 'Representative system of government' was essentially a decentralised form of the Westminster model, with executive and legislative councils following the lines of British institutions, albeit more narrowly and less democratically defined. Governors, appointed by the Crown, retained overall executive power on behalf of the British monarch, and were assisted by advisory councils solely appointed by themselves. The masses were denied the right to vote by property qualifications. It took a violent uprising by disfranchised Jamaican farmers - the Morant Bay Revolution of 1865 - before London assumed more direct responsibility for local politics and abolished the badly functioning and, in reality, unrepresentative local legislatures. During the latter part of the nineteenth century the autocratic system of Crown Colony government became established in much of the British West Indies - with executive and legislative bodies appointed by a Governor who was subject to no over-riding West Indian political authority. In doing so the British took a step backwards, only to re- 
install partly elected local legislatures during the interbellum period, and only to a limited geographical extent.

With economics being the force behind British colonisation, the gradual demise of their main export, sugar, and the growing importance of the Asian and African colonies explains the Colonial Office's waning interest in what were once the 'darlings of Empire'. Wanting the advantages of colonialism without the costs, the British acted pragmatically. For these small islands continuously facing economic crisis, they had federalism in mind as the ultimate, cost-efficient administrative arrangement. ${ }^{3}$ At the end of the nineteenth century several territories were for the first time joined together into two separate constructions: the Windward Islands Federation (1879-1885) and the more enduring Leeward Islands Federation (18711958). ${ }^{4}$ Although their subsequent history was not particularly encouraging - the federal legislatures always lacked money, the local legislatures held all vital powers, means of transportation were limited and thus communication and trade between the different islands severely hindered - in 1958 the Leeward Federation would merge into the all-embracing and short-lived British West Indian Federation.

Meanwhile these federal constructions did not bring any appreciable changes in the constitutional systems of the territories, some of which remained fully subject to an autocratic Governor, while others had local institutions with a certain degree of self-government. ${ }^{5}$ Each territory had its own structure and developed at its own pace. But the colonies were in no way centre stage in British politics, which would reflect on the status of the Colonial Office - established in 1854 - considered the 'Cinderella of the great Public Departments', with the office of colonial minister being treated as a secondary one. ${ }^{6}$ For more than a century, up until 1966 , the Colonial Office would continue to operate from London under this archaic name.

Weakened by World War I, the United Kingdom would focus mainly on its self-governing dominions for rebuilding its home economy, while engaging in a new approach to Empire, that of a voluntary co-operation structure by independent countries: the Commonwealth of Nations. ${ }^{7}$ Concurrently, the dependent parts of Empire were largely left to their own devices. Instruments such as the first Colonial Development Act in the early-1930s, allowing for one million pounds to be spent yearly on the agricultural and industrial development of all colonies, was supposed to provide some alleviation. Yet the stated objective of improving trade possibilities with the colonies was always conducted with the usual degree of self-interest.

The economic crisis of the 1930 s strongly affected the West Indian sugar industry and severly hit the region. With the exception of the occasional slave revolt and post-Emancipation social unrest the Caribbean had previously been remarkably tranquil and therefore of little concern in Westminster; the riots, strikes and demonstrations throughout the British West Indies provided a rude awakening. Social unrest suggested once again that 
local self-government - which the British and colonial elites had prided themselves on - had primarily benefited a small privileged minority. From these regional labour protests emerged political parties in many territories nurturing, over time, the wish for independence.

Even though in the 1930 full sovereignty was clearly unacceptable for the British, gradually within administrative circles an atmosphere emerged in which political change was conceivable. Following the disturbances, the West India Royal Commission toured the region, headed by Lord Moyne, who later became Minister of Colonial Affairs. Its influential report published in 1940 advised on the establishment of a development and welfare scheme for the Caribbean colonies and the introduction of institutional reforms, mainly through extending the franchise and localising the executive and legislative councils. A leading recommendation was the creation of an all-embracing political British West Indian Federation, as a first step towards greater local autonomy and future wellbeing of the colonies. Policies, in accordance, would begin by focusing on economic aid but stopped short of major governmental reforms: the British government, concerned about disruption and the possible collapse of existing institutions, would postpone the general disbanding of Crown Colony government until after the war. ${ }^{8}$

The only semblance of any pre-war British decolonisation policy was found in the drive to encourage the colonies along the road to self-government, but even this lacked any clear perceptions on the actual outcome. Federation seemed one solution, but during the war constitutional matters would essentially remain dormant. 'New' colonial politics merely suggested a change of status, that of self-government within the British Empire. ${ }^{9}$ The first example of this new approach in the Caribbean was the 1944 progressive Constitution of Jamaica. (At the time, within the non-sovereign Caribbean the level of autonomy in Jamaica was only equalled in Puerto Rico, although very different in make-up.) But on the world map of colonies British priorities clearly lay in the economically and demographically more important areas in Africa and Asia, where their power was being challenged by military uprisings.

During the course of the war, under the pressure of public opinion and American insistence on the principle of self-determination, the United Kingdom would shift towards a more positive attitude towards decolonisation, promising that in the post-war period a discussion on the future of the colonial relations would take centre stage. This would apply to the West Indies as well. American concern about the region forced the British to reexamine their approach. The burning question now became whether the smaller dependencies could be eligible for self-government within the Commonwealth. ${ }^{10}$ Having seen other former colonies grow into strong self-governing nations on equal terms with the United Kingdom, British officials now offered this prospect to the West Indian territories, although 
only in the form of a collective. Dominion status was not held out to the individual islands but - in the hope that the experience of working together would make development problems easier to solve - was proffered as an incentive to become part of a West Indian Federation. The coming years would reveal that the Colonial Office's blinkered preoccupation with administrative efficiency had overlooked the fact that few of the islands felt any desire to become part of a federation. The British government had not anticipated just how fast changes would start to happen in the following two decades.

\section{The Failure of the West Indian Federation}

After the 1945 enunciation by the British Minister of Colonial Affairs, Oliver Stanley, for a West Indian Federation to include all British territories, the Montego Bay Conference held in Jamaica in 1947 saw the coming together of all eligible territories to discuss proposals for regional co-operation under one federal government. It soon became clear that federation was indeed the only practical compromise available between the aspirations towards independence of many of the smaller territories on the one hand and the British, convinced of the unfeasibility of sustaining full individual sovereignty by these communities, on the other. The British deemed bureaucratic centralisation necessary for these territories, which in their view were unable to fulfil obligations assumed by membership of international organisations; unable to uphold a reasonable degree of self-government on their own; and unable to promote lasting political and economic progress if they were to remain separated and fail to deal with their problems in a larger context. So the argument went, but it was apparent right from the start that federation did not come about as a result of wide popular demand or political resolve in the West Indies themselves. Many forces would prove to work against the coming together of the islands.

The federal Constitution, which was drafted in the following years, did not solve issues relating to the powers of the federal government and its structure. Leaving the balance of power with the individual units, the federation was essentially confederal rather than federal - it was decided that only after five years the Constitution would be re-examined with a view to a possible strengthening of the central government. Neither were the problems of political status solved - it was only concluded that the Federation would not receive dominion status immediately. In due course it would move on to full independence within the Commonwealth. In addition, the two mainland territories of British Honduras (today Belize) and British Guiana rejected participation, fearful of assuming far-reaching financial responsibility for the small islands, which made the Federation fragile from its conception. 
General lack of consensus resulted in difficult and protracted negotiations preceding the inauguration of the West Indian Federation, which eventually took place on 3 January 1958, after twelve years of preparation and four international conferences. Participating islands were Barbados, Grenada, Jamaica, St. Vincent, Trinidad and Tobago, plus the group of islands until then forming part of the Leeward Islands Federation (Anguilla, Antigua, Barbuda, Dominica, Montserrat, St. Kitts-Nevis, St. Lucia, St. Vincent/Grenadines, Turks and Caicos Islands) - with a total population of 3.1 million.

With very little internal support the federal structure would lack cohesion and in 1962, after only four years, the 'uneasy Federation' fell apart. ${ }^{11}$ In two respects the situation had essentially changed since the Montego Bay Conference of 1947. In the first place the United Kingdom had meanwhile granted far-reaching competences in the field of self-governance to many of these territories - this was at odds with their federal position. Secondly, the most important islands - particularly Jamaica and Trinidad and Tobago - had seen years of economic growth which had given rise to aspirations towards individual independence. Thus cracks had developed in the federal structure.

When in 1960 the British Colonial Secretary Iain MacLeod declared Jamaica ready for independence, the whole construction collapsed. After a referendum in September 1961, in which 54 per cent of the electorate chose to secede, Jamaica withdrew from the Federation. While the island was preparing for full sovereignty with British consent - the 1961 referendum had actually not addressed the possibility of independence but had solely concerned itself with secession from the Federation - Trinidad and Tobago would soon follow, and the British government made a final attempt at saving the federal concept. But this Eastern Caribbean Federation - a scheme in which the 'little seven', Antigua, Dominica, Grenada, St. Kitts-Nevis-Anguilla, St. Lucia and St. Vincent, attempted to federate with Barbados failed soon after inception, for the same reasons. Meanwhile Barbados and Guiana had also started preparing for individual independence.

In hindsight the collapse of the federal experiment was not surprising. Federation may have seemed logical at the time, but its failure was sealed in the same regional fragmentation and lack of homogeneity which originally inspired these constructions. Clearly the idea had not stemmed from a deep-rooted will of the islands to unite. Real common interests had remained absent. These island economies, with their limited local markets, a narrow range of economic activities and without natural resources, were competitive rather than complementary, and thus remained largely insular. Inter-island trade and communications failed to develop. Reality had shown that these competitive tendencies, fuelled by differences in scale and cultural and economic development, had even led to a certain degree of mutual antagonism. The larger, more prosperous islands felt aversion to 
take on the financial burden of the weaker islands, the latter resented domination by the larger ones. The particularly strong competition between the primary members of the Federation, Jamaica and Trinidad, only contributed to its fragility. With the autonomous local legislatures successfully resisting subjection to a central authority, the federal government was politically weaker than the governments of the individual member states. Colonial inheritance had left little room for the succesful development of a shared (British) Caribbean identity.

After the collapse it became apparent that the federal intermezzo had only furthered the drive for independence by individual territories. During the remainder of the 196os, British withdrawal from the Caribbean was accelerated with a series of islands receiving individual independence. This was precisely the outcome the United Kingdom had tried to avoid by establishing the Federation. The transition at least proceeded without any turmoil, let alone bloodshed. Whereas the Colonial Office had originally intended a period of between five and ten years to elapse before full independence could be granted to a federal unit, it was now willing to grant independence to individual territories where it was requested. The independence of Cyprus in 1960 - Cyprus being the first island after Iceland (1946) to gain sovereignty with less than one million inhabitants - had set a precedent, with many small islands now eager to follow suit. ${ }^{12}$ Jamaica and Trinidad and Tobago were the first to be granted individual independence, in 1962, to be followed in 1966 by the other two of the 'Big Four', Barbados and Guyana - 'similarly fearing they would be impeded by the smaller threadbare territories. ${ }^{13}$ With the exception of Guyana these processes were entirely peaceful. ${ }^{14}$

The 1962 West Indies Act disbanded the Federation and also promulgated new constitutional systems for each remaining Dependent Territory (contrary to the United Kingdom most of these territories have a written Constitution) which could only be revised by British parliament. In these territories the Crown held broad legislative powers, in all areas deemed necessary for good governance. Thus all remaining islands received considerably less autonomy than they had previously enjoyed as members of the Federation. In doing so London, anxious to rid itself also of these residual territories, effectively gave a bonus incentive to attain independence.

During the later part of the 1960 s the United Kingdom adopted an association formula in the Eastern Caribbean: there, six small territories (all participants of the failed Eastern Caribbean Federation) were anxious to attain some further advance in constitutional status. While the islands preferred internal autonomy over full sovereignty, and the Commonwealth Office ${ }^{15}$ also assumed that these poor islands would be unable to sustain effective individual independence, the new status of 'Associated State' was devised. Under the form of association these territories were to be independent in all their domestic affairs, while the United Kingdom would assume 
responsibility for their defence and external relations. The territories would continue to receive aid, for which they remained answerable to London. The 1967 West Indies Act described the new ties as 'free and voluntary', and as proof thereof, every territory could unilaterally terminate all links with London and achieve independence upon a two-thirds vote of its House of Assembly, followed by a similar majority in a referendum. ${ }^{16}$ This new status, with an optimum degree of autonomy, was modelled on the arrangement granted by New Zealand to its Cook Islands. Generally it was seen as a long-term solution and labelled as 'independence in association., ${ }^{17}$

By the end of the 1960 os British responsibility in the Caribbean thus extended to seven Associated States and six Dependent Territories. ${ }^{18}$ The latter preferred to remain dependent since they considered themselves too small and too poor to move towards Associated Statehood. With respect to both categories there would be two major and clearly contrasting policy changes over the subsequent decades: in the early 1970s a ground swell of opinion would emerge within British politics, very much against retaining these 'relics of the past'. ${ }^{19}$ The United Kingdom would demonstrate its desire to sever completely the traditional bonds between the former colonies and itself. Second, after a U-turn in 1984, the original position was retaken with the government declaring that it would not force independence upon its remaining territories.

There was an obvious cause for the early-197os reversal of policy: British lingering dissatisfaction over the relations with its Caribbean territories was brutely brought to the fore with the unrest in March 1969 in the Associated State of Anguilla. Since 1967 Anguilla formed part of a tripartite Associated State with St. Kitts and Nevis, much to Anguilla's discomfort. Following a referendum that same year, Anguilla was attempting to secede from St. Kitts-Nevis. At the request of the Kittitian government, the United Kingdom dispatched troops to Anguilla. Just as the Curaçao revolt of May 1969 would illustrate only two months later, this event showed that although the metropolis retained full responsibility for these territories, it lacked the power to steer and control events..$^{20}$ Disillusioned by the entire episode, Britain decided not to confer Associated Statehood to any more states, and to make sure that the existing Associated and Dependent Territories would gain independence as soon as possible. ${ }^{21}$

Indeed, between 1973 (Bahamas) and 1983 (St. Kitts-Nevis) the United Kingdom would prove to be an old hand in decolonising the West Indies. All but one Associated State became independent within the Commonwealth. Anguilla, at its own request, took a step backward and in 1980 received its present status of British Dependent Territory. The island settled for this status to ensure its immediate goal: separation from St. Kitts. ${ }^{22}$ Local legislatures generally supported the choice for independence - even though referenda on the subject were never conducted ${ }^{23}$ - and the Foreign and Commonwealth Office (FCO, in 1968 the Commonwealth Office had 
merged with Foreign Affairs) was more than happy to grant these requests, particularly as they did not imply financial support. Anxious to emphasise the need for financial self-sufficiency, it would grant none of the territories an 'endowment' upon reaching independence. British political culture would persist on the islands through structural West Indian imitations of 'Westminster'; the inherited model adapted to the local situation, but essentially unchanged in structure. ${ }^{24}$

In 1983 Associated Statehood was fully laid to rest. ${ }^{25}$ With little desire in the remaining Dependent Territories to reach independence, during the course of the 198 os pressure on these territories to go down that same route would also end. Essentially in view of the economic and political crisis in the region, the Conservative government under Margaret Thatcher, in office from 1979, now became more involved again in Caribbean affairs. The region began to reveal itself as 'a cockpit of international conflict and competition, involving the two superpowers - the United States systematically as "protector" of its "back yard" and the Soviet Union via the alleged proxy activities of Cuba. ${ }^{26}$ The United Kingdom actively sided with the United States.

\section{Re-engagement: The Overseas Territories}

The American invasion in 1983 of Grenada, in which Washington rudely by-passed London, along with the Falkland/Malvinas war, highlighted the fact that neglect of colonial responsibilities could seriously undermine the geopolitical weight of the metropolis. In reaction, the need grew for a better positioning, and at the same time a renewed acceptance of the remaining Dependencies. In October 1984 the Minister of State responsible for the Caribbean, Baroness Young, enunciated in an important reappraisal a series of initiatives that amounted to 're-engagement rather than disengagement'. British input was now defined as 'the maximum possible British trade and investment in the area notwithstanding the inevitably small size of the market'. Small-scale was accepted as an argument against independence. ${ }^{27}$ This new British responsibility would later be linked to fields such as security, trade, development aid and the fight against drug trafficking. Independence was now seen as undesirable, and the question was posed within British government as to whether it had been wise to grant independence to a series of smaller islands in the first place.

In the next period the Thatcher government, followed by the Conservative cabinet under her successor John Major, would continue along this line of renewed commitment, whereby geopolitical considerations and the fight against drug trafficking and international criminality would receive highest priority. Following the discovery in July 1986 that the government of the Turks and Caicos Islands was involved in drug smuggling activities, the FCO under parliamentary pressure undertook a review of policy to- 
wards its Dependent Territories. The ensuing report of December 1987 concluded that the existing policy was sound, but that there was need for improvement in the quality of local administrations. The problems on the islands, so it was stated, should not be regarded as a reason to further them in the direction of independence. In 1990 the same view was reiterated, with the British government formulating its views on independence as follows: 'We would not urge them to consider moving to independence, but we remain ready to respond positively when this is the clearly and constitutionally expressed wish of the people. ${ }^{28}$

On 27 August 1997 Foreign Secretary Robin Cook announced a thorough review of the relationship between Britain and what were then still called the Dependent Territories. This fresh impetus came about with the coming into office of a new Labour government under Tony Blair, in May 1997. The volcano disaster on Montserrat (July 1995), the growing awareness of the economic problems on many islands and the then imminent hand-over of the Crown Colony of Hong Kong to China were contributing factors. ${ }^{29}$ One and a half years later the government concluded its redefinition of this relationship: in March 1999 the White Paper Partnership for Progress and Prosperity-Britain and the Overseas Territories emerged, containing many recommendations on future and constitutional advancement of the territories, which in the future would be known as the United Kingdom Overseas Territories, abbreviated to oTs. ${ }^{30}$

With this White Paper the territories, usually sidelined by the government, have seen their position brought under the political spotlight. With regard to constitutional issues it concludes that 'neither integration into the UK, nor Crown Dependency status, offer more appropriate alternatives to the present arrangements. ${ }^{31}$ So no changes there. For the territories, one of the most significant consequences has been the repackaging of relations into a 'modern partnership' which implies, in return for Britain's willingness to respect the wish of the islands to continue under British sovereignty, that certain obligations must be adhered to. Included in this is the observance of human rights, law and order and good governance. The White Paper summarises many areas in need of attention: considerable improvements are to be made in the administration of the territories (including the promotion of representative and participative government) and with regard to their financial accountability (effective regulation of their financial offshore sectors which boomed somewhat uncontrollably throughout the 1980 and 199os). In addition, Britain requires implementation of comprehensive measures to combat money laundering, drug related criminality, financial fraud, terrorist funding and tax evasion: all areas attracting increasing international attention. Thus the British have certainly asserted their authority in a manner not seen for decades - the pledge to respect the отs' wish to remain linked to Britain was certainly not granted unconditionally. 
New initiatives in order to improve communication between the territories and the government have been introduced in the institution of a special minister for the Overseas Territories within the FCO (within which also a new Overseas Territories Department was set up), and an annual Overseas Territories Consultative Council, bringing together British ministers and local ministers to discuss matters of common concern. Another remarkably positive development was the offer of restoring British citizenship to all former 'Dependent Territory passport holders' should they desire it, along with free access to the United Kingdom. This has since come into effect, albeit a full three years after publication of the White Paper. ${ }^{32}$

It has been observed that the White Paper makes no attempt to put figures to the many action points outlined within the sphere of good governance, which in reality affect mainly the agendas of the Caribbean Overseas Territories themselves. The question thus remains what incentive there is for them to implement these action points. To redress the vagueries of this partnership further input will be required by the British. It can be reasonably stated that a more proactive British stance will certainly be needed to create a truly working partnership.

The United Kingdom's decolonisation of the West Indies thus resulted in twelve politically independent countries - dominions within the British Commonwealth - and six so-called British Overseas Territories: Anguilla, Bermuda, British Virgin Islands, Cayman Islands, Montserrat and Turks and Caicos Islands. The latter group is administered by 'Her Majesty's' Governors', with different degrees of local autonomy. Bermuda is the most autonomous island of the 'OTs', but even there political influence on British policy making is practically non-existent. ${ }^{33}$ Internal self-government is generally provided by an Executive Council and elected Legislature. Governors or Commissioners are appointed by the Crown on the advice of the Foreign Secretary - typically their powers include areas such as defence, foreign affairs, public order and internal security. In some cases the Governor also controls the conduct of the offshore banks.

The islands' education and legal systems have much in common with those in the United Kingdom. Although there is great diversity in terms of size and economic development, their economies are based primarily on tourism and offshore finance. Under the wings of the United Kingdom, the OTs are assured military protection, access to the European market, development aid from Brussels and, if necessary, from London. ${ }^{34}$ Despite longstanding British attempts to remove the oTs from the United Nations list of Non-Self-Governing Territories (rooted in the expressed viewpoint that the territories are the sole responsibility of the United Kingdom) all of these still figure on this list, which obliges the government to report annually on their political and socio-economic development. ${ }^{35}$

In short, post-war the British West Indies became the residual territories, administrative and economic appendages in the shadow of the large 
African and Asian colonies of a fragmenting Empire. After the failure of the West Indian Federation (1958-1962), envisaged as a construction for collective independence within the Commonwealth, the British Caribbean developed into a politically heterogeneous collection of territories, which the British dealt with in their own pragmatic way. Until the end of the 1960 s the Commonwealth Office held the view that independence was an option, but not necessarily the desired outcome for all Dependent Territories. Between 1969 and 1984 this approach started to change, with the United Kingdom attempting to rid itself of the territories as quickly as possible. Anxious to leave the region, sovereignty was hastely granted to a number of smaller territories. This change of policy can be levelled at the United Kingdom's perceived lack of interest, dissatisfaction with local political developments and general concern regarding its self-image in the international arena.

Until the mid-1980s the United Kingdom failed to anticipate that requests for continued political links would come from many of the remaining Territories. But with the realisation that it was senseless to grant dominion status to the remaining small and economically weak OTs, direction would again change. Since the mid-1980s the choice for status lies fully with the OTs themselves; the United Kingdom does not apply any pressure in the direction of independence. It is remarkable that - unlike the other three metropoles - the United Kingdom never supported its decolonisation policies through economic aid. Determined to procure financial self-sufficiency for the islands, aid was never an instrument for keeping the territories within the Empire, nor was it ever a reward for accepting independence. The United Kingdom assumes that the territories are largely self-sufficient, providing modest aid to only three in the Caribbean. ${ }^{36}$

In the new millennium it is clear that the remaining Overseas Territories see their 'colonial' status as permanent ${ }^{37}$ - to a certain degree of satisfaction on both sides of the Atlantic. The 1987 review reiterated the line that the United Kingdom would no longer influence the territories in the direction of independence. Twelve years later, in March 1999, this stance was once again emphasised, as stated in the Foreign Secretary's White Paper Partnership for Progress and Prosperity. With this it was formally acknowledged that these islands will remain connected to the United Kingdom for the foreseeable future. Westminster no longer focuses on policies devised for a transfer of sovereignty. The new policy for the оTs is based, in theory at least, on a partnership with mutual obligations and responsibilities. Considerations on both sides explain the permanent character of this seemingly 'stagnating' decolonisation.

Culturally, the отs bear the legacy of centuries of British colonisation, first and foremost in their language, but also in the perpetuation of British institutions. Orientation on the outside world, however, is not limited to the metropolis but perhaps extends even more to the United States, the ma- 
jor English-language power in the region. Of course it helps that there is no pervasive economic dependency on the United Kingdom. Moreover, the prohibitive metropolitan immigration laws have prevented the emergence of a significant transnational extension of the oт population in Britain itself. The contrast with the other non-sovereign Caribbean territories is obvious. 


\section{The Comparative Context: The French départements d'outre-mer, Grandeur and Civilisation at a Price}

French attitude toward empire fundamentally differed from that of the British, who generally liked to keep their colonies at arm's length while gradually reducing their overseas spheres of influence by decentralising power and handing out the trump card of self-government - and eventually sovereignty - within the Commonwealth. France, in contrast, would not attempt to rid itself of its important strategic legacy. Within the French system of decolonisation the possibility of dominion status was inconceivable. The doctrine of self-determination as proffered by the British Prime Minister Harold Wilson was dismissed by a French representative as 'C'ést simplement absurde'. Instead of 'some showy federation of the Caribbean', France chose to assimilate its vieilles colonies into the very bosom of its Constitution, aiming to create close and enduring bonds. ${ }^{1}$

Despite these varying political philosophies, there are certain parallels to be drawn on the outcome of the French and British decolonisation policies: France and the United Kingdom have both seen their early colonial possessions in the Caribbean become almost the last vestiges of their once global colonial empires. Thus France is also back where it first began. In addition, just as the British Commonwealth is founded primarily on a 'bond of sentiment' - in which the member states feel united by a sense of solidarity personified in the British monarch - French decolonisation in the Caribbean, maintained since 1946 through départementalisation, was initially inspired by the affinity between France and its colonies. Such archetypal European traits are to be found nowhere in the region except in the départements d'outre-mer (DOM) of Martinique, Guadeloupe, including the French half of St. Martin, and Guyane. It is generally felt within the métropole that these places are segments of France which happen to lie in the tropics. The same is true of the fourth DoM, the island of Réunion situated in the Indian Ocean. $^{2}$

In 1946 the French Caribbean became fully integrated into the French Republic as departments on a constitutional par with those in mainland France. A daring experiment, the probability of its success was not supported by history. ${ }^{3}$ For la France métropolitaine, the common French expression for European France, and the Dom there is one law, one nationality, and one parliament. ${ }^{4}$ The inhabitants of the DOM are French citizens with the right to vote in the presidential elections. This constitutional position has been slightly modified since - to facilitate larger degrees of self-government and can still for the most part count on the approval of the great majority of the Dom population. 
Even though beyond the borders of France there has been much criticism regarding this legal and political assimilation, which according to critics is nothing other than a veiled annexation, France is not ashamed of this constitutional connection. On the contrary, it has always been prepared to pay large sums of money to perpetuate its standing. And although this financial burden shows no sign of diminishing, the nation does not consider this a heavy moral or historical obligation. France does not want to lose its Caribbean departments: they are Francophone outposts in a largely English-, Spanish- or Portuguese-speaking continent, providing la mère patrie with an unequalled - strategic - presence in this corner of the world. It is of course hugely beneficial that increasingly Brussels shares the financial burden; and beyond that, much of the financial support is spent on French goods and services anyway.

\section{The Colonial Period}

The first French settlement in the Caribbean dates from the beginning of the seventeenth century. ${ }^{5}$ Guyane was conquered in 1604. In 1635 Guadeloupe ${ }^{6}$ and Martinique came under French rule. St. Martin was divided between the French and Dutch in 1648. In 1697 Saint-Domingue was captured from the Spanish, but in 1804, following the famous slave revolution which began in 1791, it became the first independent Republic in the Caribbean under the name of Haiti. Following this loss, Guadeloupe and Martinique, both sugar producers, became France's primary colonies in the region. Guyane had few sugar plantations and served mainly as a penal colony for French prisoners.

The current ties between the metropolis and the French Caribbean originate from the period of the French Revolution (1789-1799). The ideology of 'liberty, equality and fraternity' should apply to all residents of empire, so the doctrine went - though conveniently the slave majorities in the Caribbean colonies swiftly became exempt from this equation. As a result, as early as 1789 a number of white free men from the vieilles colonies held a seat in the French parliament (this privilege was only briefly abolished following the restoration of absolute monarchy, in 1815$) \cdot{ }^{7}$ And with the First Republic fully adopting the traditional unitarianism of the monarchy, by 1795 the old Caribbean colonies had been declared integral parts of the metropolis. In 1833 new political rights evolved, with their free inhabitants being given the right to vote. Following the Revolution of 1848 , under the Second Republic (1854-1870) an administrative division was made between France's old, seventeenth-century colonies on the one hand, and all newer, nineteenth-century - African and Asian - colonies on the other. Whereas the latter remained subjected to an authoritarian regime, the former received increased freedoms. In the French Caribbean slavery was now abol- 
ished entirely (1848), full French citizenship was transferred to all inhabitants, and the entire male population was given the right to vote.

With the coming into being of the Third Republic, in September 1870, Martinique, Guadeloupe and Guyane were permitted to elect local councils with competences such as the budget right and the regulation of customs tariffs. Yet these 'representative' institutions were only of an advisory nature, while the elective system was primarily aimed at protecting the interests of white minority groups, and all legislative competences remained firmly within French parliament. With national legislation extending overseas by decree, gradually the administrative structure of the tropical colonies became moulded on the highly centralised French state. Concurrently the French protectionist system would serve to heighten economic dependency: as of 1892 a one-tariff union was formed with the French Caribbean, permitting free access to the French market while subjecting foreign imports to high tariffs. Yet only post-World War II would a true French investment policy for the Caribbean be introduced: despite earlier proposals in that direction, grafted onto the British Colonial Development Fund of 1929, legislation was not implemented. ${ }^{8}$

World War I would make France heavily reliant on military assistance, materials and food from its colonies that - as had occurred in the British case - increased their level of importance. ${ }^{9}$ But contrary to Westminster, where the concept of Caribbean federation was tentatively probed, the French government departed from the unitary thought, that of la plus grande France, where it had a 'mission' to fulfil. Even though French colonial thinking bore the stamp of Republican ideals, that of equal citizenship and solidarity, the French were no strangers to supremacist tendencies, which made them considerably less reticent to influence foreign cultures than other colonising powers. In the French ideology language and culture connects men, not race. France's mission civilisatrice aimed at disseminating the culture of la belle France, thus turning all inhabitants of the empire into Frenchmen, regardless of colour, religion or cultural tradition. Throughout the interwar period colonial politics would remain dominated by slogans such as 'une nation de cent million d'inhabitants' ('a nation of one hundred million inhabitants'), defining France and the colonies as a whole. During the 1930 s the French empire would reach its high point, with important colonies across large parts of Africa, the Middle East and Indochina.

French colonial thinking followed the premise that as the Republic was a single unit, the territories forming integral parts should be assimilated thus establishing legal equality with the Republic. Although attempts to introduce the same assimilation policies in the newer colonies would soon falter (the legal and political assimilation of Algeria being an exception), even during World War II preparations were made for the post-war assimilation of France's vieilles colonies, Martinique, Guadeloupe, Guyane, and 
Réunion. The rapid capitulation to Germany, in June 1940, and the subsequent occupation by the German army seriously undermined French authority overseas. Following France's defeat, General Charles de Gaulle governed the 'Free French' from London (and later on from Algiers, the new capital of the temporary government), while the wartime government under Pétain collaborated with the Nazis and established itself in the unoccupied sector of France, Vichy. Subsequently both governments would strive to gain control over the French empire. The colonies in the Caribbean - as well as large parts of Africa - refused to recognise de Gaulle and became Vichy adepts instead, and would remain so throughout most of the war.

The Atlantic Charter of Roosevelt and Churchill would have its repercussions in the French colonies. Yet despite the principle of self-determination that it contained, French policies remained focused on the unity and integrity of empire. Anti-colonial protest was allayed with the announcement of post-war reforms. During the Brazzaville Conference held in the Congo in February 1944 the initial impulse was given to these reforms. However, this conference, intended as a gesture to the nationalist aspirations of the African colonies, was mainly seen by de Gaulle as an instrument to continue the State's imperial tradition interrupted by the war. Instead of making self-government the goal, decolonisation was defined as political integration through federalisation, thus ensuring colonial representation in the French parliament. It remained unclear whether this structure would be a fully-fledged federation, or whether the State would essentially maintain its imperial position. In the end the federal concept appears to have been adopted primarily to ward off American anti-colonial propagan$\mathrm{da}$, without having to relinquish the ambition of la plus grande France.

The Brazzaville Conference was the platform for the foundation of the post-war Union Française, with which France was hoping to suppress the overseas movements towards secession. Yet important issues such as the division of competences between the national parliament, the federal assembly and the territories were not discussed. De Gaulle had shown some willingness for reform by reconsidering the position of the colonies, but he stopped short of any detailed programme for the empire's future. This would have its effect on the Constitution formulated in 1946 under de Gaulle's rule, who in August 1944 entered liberated Paris in command of the French troops and became leader of the interim government until October 1946.

\section{Decolonisation through Integration}

The structure of empire would not stay the same for long. In 1946, with the coming into being of the Fourth Republic (1946-1958), the bond with the colonies was transformed into a federal structure with a strong central 
authority, l'Union Française. Relations were redressed and now characterised as a communal agreement with the metropolis. For the first time in history the Union gave a constitutional basis to la plus grande France: on the one hand the 'indivisible' French Republic, including the départements and territoires d'outre-mer as well as two collectivités territoriales; and on the other hand the états and territoires associés, both intended as a middle road between autonomy and integration..$^{10}$ In the wake of the Brazzaville Conference the Union's Constitution steered clear of any hint at self-determination or autonomy - in the metropolis it was feared that this would inevitably carry with it the risk of secession, which was irreconcilable with the French claim to hegemony. ${ }^{11}$

Prior to the approval of the new Constitution by the French people, the first Constitutional Assembly had already unanimously decided, by décrèt of 19 March 1946, that the French Republic was une et indivisible and it had classed the vieilles colonies among the French departments, as integral parts of the Republic. ${ }^{12}$ Next, under the Constitution of 27 October 1946, these parties intégrantes became départements d'outre-mer - in keeping with the mainland departments, each with their own, directly elected conseil général, although all legislative powers remained, as of old, in the hands of the metropolis. ${ }^{13}$ The Dom would no longer be governed by colonial Governors who until then had operated under the Ministère des Colonies - but instead by a Prefect appointed by the French government and answerable to the French Ministry of Interior Affairs. As of now all inhabitants of the DOM were citoyens de la République, French state citizens with identical socio-economic and political rights, freedoms and obligations.

Laid down in the Constitution (Article 73) is a clause allowing exceptions to be made for the Dom regarding the general implementation of national legislation as and when differences between the overseas and mainland departments justify this. ${ }^{14}$ Yet the Constitution made no attempt to specify which type of legislation was open to change; it only declared all laws adopted after 1946 automatically applicable in the Dom unless stated otherwise. Some earlier legislation - which needed to be especially promulgated before it was applied overseas - was never revised, so from the very start legal discrepancies between the French and the overseas departments were ignored. An early and still extant example was the continuation of the overseas tariff system, the so-called octroi de mer: a consumption tax levied on certain DoM products since 1890.

Départementalisation was a rather simple institutional operation, and apparently French decolonisation of the Caribbean had thus 'been implemented with one stroke of the pen'. However, the government had clearly taken no chances with admitting the West Indies into the French 'family'. ${ }^{15}$ Long-standing representation within the National Assembly had assured direct contact with West Indian representatives over a considerable period of time. Historical ties, and the degree to which linguistic and cultural as- 
similation had already taken place, furthered by overseas education largely following the French example, smoothed integration. The decision to include the vieilles colonies as integral departments of the State, carrying with it a maximum of French control, thus appeared no more than a logical and natural step on the path to decolonisation. With no serious objection within the Constitutional Assembly regarding the inherent costs, the assimilation law had been accepted with unanimity - despite some concern voiced regarding possible long-term effects on self-reliance. ${ }^{16}$

Yet départementalisation had not been a one-sided affair and should not be seen only as the French response to demands for post-war reform, but also as a reply to repeated demands by the Antillean political elites, who had been virtually unanimous in their desire to emancipate and ensure their economic and social development through complete integration into la mère patrie. Prior to 1946 several initiatives for greater legal assimilation had already come from the French Caribbean - seeing départementalisation as the sole path to social progress (1890, 1915 and 1919) ${ }^{17}$ Although the colonies had been largely cut off from the metropolis during World War II, and for the first time had had to support themselves, no organised call for autonomy, or even sovereignty was heard. On the contrary, after the war, the French West Indies found themselves in serious economic trouble and expectations of integration into the French state ran high, especially with regard to social and economic reform and assistance. With this assimilation complète emphasis was also placed on unconditional French citizenship: if one was to receive the same rights as Frenchmen-in-France, the old structures and colonial legacies would evaporate, so it was hoped. In any case, Caribbean opposition to full departmental status remained minimal. ${ }^{18}$ That integration into the Republic might well be at odds with the further development of Antillean identity was apparently a compromise most were prepared to make.

Since a French department is not a colony, under the Constitution of October 1946 the French West Indies lost their colonial status. France could thus proclaim an end to its colonial administration in the Caribbean, which would also affect its own status within the United Nations, where the DoM in 1947 - in accordance with the terms of Article 73 of the Charter - were indeed removed from the list of Non-Self-Governing Territories.

The attempt in 1946 to create a stable Union would not be long-standing. Just as the short-lived Dutch-Indonesian Union (1949-1952), French federalisation had primarily originated from a desire to keep the Asian possessions (Indochina) within the empire. ${ }^{19}$ The independence gained by Syria and Lebanon in 1946 would set a precedent throughout Africa and Asia, with many territories there reaching sovereignty during the 1950s, either directly or through an associated status - including Indochina in 1954. As a result, the international standing of France would considerably diminish and most of its global aspirations put to rest. ${ }^{20}$ In 1958 , the 
Union, and with it the Fourth Republic, collapsed in the midst of the independence war of the assimilated territory of Algeria.

The new Constitution was effective as of 4 October 1958. De Gaulle, who was given wider competences, became the first President of the Fifth Republic. The overseas empire was reorganised and now became a Communauté (1958-1960), which - significantly - lost the adjective Française: all trust territories and remaining former colonies were given a large degree of autonomy and were to be loosely associated with France. As a rule the DoM, being integral parts of the Republic, were excepted. For the State a primary role was reserved in the fields of foreign affairs, defence and economics. Again, however, this would be a short-lived structure. In 1962 Algeria was granted sovereignty after a long and bloody war and by the early 1960 all larger possessions had gained independence, resulting in bilateral forms of cooperation bearing little semblage of a 'Commonwealth à la française'. Geographically, grandeur now boiled down to a strengthened position of France within Europe and a handful of smaller French territories scattered around the globe. ${ }^{21}$

The Constitution of October 1958 (which is still in place today) confirmed the principle of legal assimilation of the départements d'outre-mer into the Republic. In addition it was stated that in the future the departmental assemblies - conseils généraux - should be consulted during the legislative process. The Constitution was also partly rephrased in a bid to clarify the 1946 regulation: instead of allowing for overseas 'exceptions' in national legislation, Article 73 now stated that for the Dom 'adaptations' were feasible, should local circumstances require so. Thus any discrepancies between the law at home and overseas were to be regarded as adaptations, not as exceptions to the rule. ${ }^{22}$ Although the Dom were to resemble the mainland departments to the largest extent possible, in actual practice considerable differences, particularly in the field of social security, would persist. Also the competences of the Dom Prefects remained more extensive than those of their metropolitan counterparts.

Although the Constitution permits territoires d'outre-mer to secede or become départements, it remained unspecified whether the departments themselves could change their status. The apparent conclusion is that for the Dom the right to political self-determination is not an option since this would imply that each department could make this claim. This is confirmed by Article 5 of the Constitution, which states that the president 'est le garant [...] de l'intégrité du territoire' ('the guarantor of the integrity of the territory') and by Article 1, which continues to describe France as a 'République indivisible'. ${ }^{23}$ 
Departmentalisation held the promise of economic development and a standard of living equal to that of the metropolis. However, it would soon prove extremely difficult to implement far-reaching changes in the overseas socio-economic systems. Although the French Antilles and Guyane are now departments, with wages and social benefits largely on a par with French levels, the reality is that their productive capacity has not increased. On the contrary, to a large extent the Dom lost the capacity for production: today eighty per cent of required foods are imported; exports - mainly in the form of rum and bananas - amount to only one seventh of imports. In short, they are heavily dependent and rely on what Paris and Brussels care to provide in terms of financial assistance, and the success of local leaders is judged on the financial assistance they manage to procure and its subsequent implementation. ${ }^{24}$

One of the more thorny areas of assimilation à la française has proven to be the direct overseas application of all social legislation. The high cost of implementation contributed to its continual postponement in the initial years. Despite their constitutional parity with metropolitan départements it would take until 1996 before social alignment became established and the social security system of the DOM was connected to that of the metropolis. In the late 1990s, the minimum wage still stood at ten per cent below that of the metropolis, but recently is was set at parity. ${ }^{25}$ Artificially high wages almost equivalent to those in la France métropolitaine and many times higher than levels found in surrounding islands - have resulted in a downward spiral of a reduction in working hours and a rapid rise in unemployment generally oscillating between 25 and 30 per cent. Due to France's high profile civil service, local career aspirations tend to focus on the public sector. Some 35 per cent of all labour is employed by the state. Salaries in this sector have a 40 per cent bonus over and above the metropolitan standard to make up for the higher cost of living. ${ }^{26}$ At the same time, the unprecedented influx of metropolitan civil servants to the Dом has led to frustration among the local middle classes, who saw jobs effectively transferred to these executives (who receive an additional supplément colonial). Today approximately 3,60o civil servants from the Secrétariat d'État à l'Outre-Mer (SETOM) are stationed in the four DoM. ${ }^{27}$

Until the mid-195os legal assimilation with the State, with full civil and political rights, would remain the undisputed goal of all French Caribbean political parties. Around the start of the Fifth Republic, however, 'centreperiphery' tensions would increase to such an extent that a revision in the allocation of power was clearly required. Integration into the highly centralised State was no longer satisfactory for the local political elites, who began to nurture aspirations towards autonomy. ${ }^{28}$ Connected to this was a shift between left- and right-wing factions regarding the 'status issue'. In a 
turnaround in their policies it was now the communists and other leftwing factions who demanded larger administrative (not economic) autonomy and who turned against integration, whereas the right-wing parties were striving for further centralisation.

Remarkably, it would be precisely the (co)instigator of départementalisation, the Martiniquan writer, politician and mayor of Fort-de-France Aimé Césaire, who played a pivotal role in this change of tack. ${ }^{29}$ Césaire now expressed negative opinions regarding départementalisation. Assimilation, so he concluded, had proved to be a stagnating factor rather than a stimulus for economic progress. With the Dom being heavily subsidised by the State, domestic employment was extremely limited and entrepreneurs were unable to survive the heavy burden of the French tax system. Césaire even argued that the French Antilles were among the last few remaining colonies. As a solution he proposed a larger degree of local autonomy - while maintaining the constitutional bond with France - enabling the islands to handle their own internal affairs. Other left-wing parties now also saw départementalisation as impeding progress. Yet the French government was of the opinion that if all demands of the left-wing factions were met, the French Caribbean would lose its Dом status, and with this all rights to financial support. ${ }^{30}$

The 1960 s would prove an important turning point in the history of the Caribbean. In the context of many small territories gaining independence, the French approach met with increasing resistance in the Dom. Their status, long considered the ideal path to decolonisation, was now seen by the autonomistes as inconsistent with the global and regional movement toward full sovereignty. Left-wing politicians judged the politics of assimilation a failure since underneath the new, artificial economic growth without genuine development, ostensibly the old colonial structures had persisted. The fundamental problems had not been solved..$^{31}$ Increased resistance to the hégémonie assimilationniste was coming to the fore in strikes and riots. Alongside the autonomistes now also indépendantistes were ascending on the political scene.

In order to counterbalance political unrest, constitutional reform - départmentalisation adaptée - was introduced in April 1960, as part of an overall restructuring process under the Fifth Republic. The advisory powers of the departmental assemblies were enlarged (now with the power of amendment), and the departments were given new competences in the fields of health care, social security, infrastructure and education. The Prefects assumed more powers than previously; communication between the central ministries and local administrations was enhanced. ${ }^{22}$ Yet all of this went only part way to meeting local grievances and failed to redress the ingrained malaise within the community. Equality between the Dом and the metropolis remained unforthcoming. Certainly local wages and social benefits were - and still are - exceptionally high with respect to Caribbean 
standards, yet precisely because of the incorporation into metropolitan France, the Dom continue to compare their condition with the standards of the distant metropolis. Thus the 1960 reforms, mainly reinforcing the role of the decentralised authorities in the legislative process, could not prevent discontent resurfacing with increased intensity, especially in Guadeloupe where serious riots erupted in the late 1960s..$^{33}$

The French Caribbean having been for many years - to the outside world at least - a place of peace and prosperity, would evoke an altogether different image throughout the 1970 as separatist movements would repeatedly turn to violence. ${ }^{34}$ This was most acute in Guadeloupe, with a series of bomb attacks, mainly targeting hotels and government institutions. Looking back, however, this seems to have only been an interlude. Following further decentralising measures introduced in the early 1980 - and, of course, continued massive metropolitan subsidies - violent campaigns for independence would peter out.

The 1982 constitutional reform became part of an overall reassessment of the French administrative infrastructure under the socialist government of President François Mitterand, who felt the Dom deserved the 'right to difference. ${ }^{35}$ With the establishment of the new administrative unit of the région, each Doм now also became a région d'outre-mer (RоM), or région monodépartementale, with a new locally elected regional assembly (conseil régional) mainly responsible for long-term regional development and education. The decentralisation law reinforced the powers of the two local assemblies in the legislative process and extended the scope for local decision making. ${ }^{36}$ The role of the Dom Prefect now extended to the Rom. The Prefect's executive power was largely transferred to locally elected authorities - in fact the first large concession in the direction of local autonomy for the ром in history. These reforms would again - for the time being - quiet most calls for increased autonomy.

Since the 1982 decentralisation measures the French government has gone some way to implement new reforms, providing local administrators with increased powers. There is a recognition in Paris that the inherent problems faced by these small and relatively isolated territories are often only compounded by their incorporation into the Republic. If departmentalisation has succeeded in a number of fields, it has undoubtedly shown its limitations with respect to economic development. The heavy tax burden on businesses along with the high wage and benefit levels may have helped its inhabitants gain a reasonable standard of living, yet have only compounded this malaise and thus amplified recent calls for significant restructuring. ${ }^{37}$

Recent developments testify to continued discomfort and a striving to address the short-comings of the present system. In the summer of 1999 the report Les départements d'outre-mer aujourd'hui: La voie de la responsabilité was published, written on government order by Claude Lise and Michel 
Tamaya, respectively senator of Martinique and Réunionnese deputy. The Lise-Tamaya report highlighted many shortcomings of the current political system and concluded that the DOM should be given a bigger say in the implementation of French economic assistance. It also concluded that they should have more decentralised competences, especially with regard to economic planning, even if this would necessitate constitutional change, along with a more accurate division of duties between the two local assemblies. Lise and Tamaya also argued that local authorities should gain more competences to forge bilateral agreements with neighbouring islands. ${ }^{38}$

A visit by Prime Minister Lionel Jospin to the French Antilles in October 1999 convinced him of the need for the introduction of this framework law for the overseas territories, believing it would go a long way to promote 'sustainable growth in these regions, valorising their assets, helping them compensate for their backwardness in public facilities, ensuring social equality and equal access opportunities to education, training, and culture and equality between men and women'. ${ }^{39}$ In December 200o, the Jospin administration indeed submitted a potentially far-reaching framework for local socio-economic and political development and further decentralisation, the so-called Loi d'orientation pour les départements d'outre-mer.

This last round of decentralising legislation, should it be passed by French parliament, may mark an end to the Dom as we have known them. For the time being however stagnation is immanent. While the Caribbean DOM are in favour of the new legislation, Réunion has explicitly expressed its opposition. Furthermore, now that a new, right-wing government rules France, this project initiated under its leftist predecessor may well encounter more delays. ${ }^{40}$ In the end one doubts whether any fundamental change is at all conceivable, given the many advantages the inhabitants of the DOM enjoy despite all the drawbacks. By lavish subsidies and by placating nationalist forces, the French government has been able to secure the continuation of the DOM system. In fact, the proclaimed separatists too became part of the legitimate political process. Some headway made by these nationalist movements is visible in the seats they now hold in locally elected councils, particularly in Martinique. Their antagonism towards the French stimulates a lively political discourse, yet there is little reason to assume that either its leadership or its electorate are really aiming for sovereignty. ${ }^{41}$

Beyond the borders of France the equal status of the Dom with the rest of the Republic is generally regarded as a 'legal fiction, or even as a hangover from the colonial area'. ${ }^{42}$ A total assimilation of France's overseas departments was clearly unrealistic. The fact that the Dом are essentially different is even laid down in the French Constitution (Article 73). Yet in the French Caribbean anomalies between the Dом and the metropolis are often interpreted as proof of second class citizenship and of 'colonial' treatment. Anti-establishment movements feed on such discontent, but for the 
majority of the population the advantages of dependency continue to outweigh the related drawbacks.

The relationship with the European Union has undeniably had its additional advantages. As integral parts of France and the EU the Dom enjoy free access to the European market, which at least in terms of imports is significant. More importantly, they are entitled to considerable funding, mainly through the Eu Structural Funds for the development of lesser developed regions. In addition, all ром inhabitants enjoy free movement within the European Union, carrying with it the right of abode. ${ }^{43}$ There are also negative aspects to this incorporation. Losing French protection to an increasing extent, the uncompetitive Antillean agrarian sector has suffered tremendously in the free market. Within the present construction defined by high subsidies, wages and benefits, it is unlikely that the Dom will ever function competitively. The Dom's European orientation too appears to leave virtually no room for them to play a regional role, with at present only five per cent of trade being regional. Tourism is in fact the only regional connection of any consequence. ${ }^{44}$ Again, a reason for frustration. Yet as Fred Constant writes, 'The paradox is here that this rethoric of challenging the French State and the European Community has been accompanied by increased lobbying in Paris and Brussels'- to enhance the contribution of 'Europe' to the DOM to be sure. ${ }^{45}$

So despite some local discontent, the pragmatism of almost one million French Caribbean citizens - and of their political leaders wary of jeopardising their comfortable distributive function - will ensure the longevity of dependency cemented by considerable financial transfers ranging from $€ 2,900$ to $€_{3}, 800$ per capita a year. ${ }^{46}$ Recent surveys in Martinique disclosed that 52 per cent thought of the Dom status as 'rather positive', and 26 per cent 'very positive'. Assimilation, according to William Miles often interpreted as 'a code word for alienation', elicited positive response with 45 per cent of the respondents, as against a negative one with 24 per cent. What about independence? 12 per cent thought this should be the status in fifty years' time - and only 4 per cent opted for sovereignty at an earlier stage. ${ }^{47}$ The citizens of the French Caribbean show no real interest in a fundamental change of their comfortable, if at least for some, frustrating status. Thus these Dom will retain their unique position in the region. Observers often describe this position in ironic terms. Le Monde Diplomatique recently characterised unrest in Guadeloupe as an expression of 'the cultural misery of a people without a purpose'. Others speak of a 'welfare mentality'. Anthropologist Richard Price, commenting on forty years of rapid change in Martinique in which the island moved from 'a producer economy to a heavily assisted welfare-based consumer economy', speaks of a 'bourgeoisification (thanks to the floods of money distributed by the French state)' which produced such remarkable phenomena as 'local people who go on Caribbean cruises' and 'local women who not only drive вMws and initiate divorce, but who own poodles, on leashes'. ${ }^{48}$ 
Outside pressure for sovereignty is unlikely. The status quo is perfectly acceptable to the French, with the continued value placed on their presence in the Caribbean as, in Réunion, in the Indian Ocean. On behalf of a growing number of European countries without any colonial antecedents, Brussels might complain about the cost, but will not find this issue important enough to go any further with. Meanwhile, virtually all political activity in the ром is played out under the financial and political umbrella of the French state and the EU, which only compounds the dependent nature of the relationship. Even if the present call is one for increased autonomy, where most of the metropolitan laws will cease to apply and specific laws for the Dом will be made by the local assemblies themselves, no future French Caribbean legislator is likely to abandon the many advantages of post-colonial dependence. The political instability and economic problems of many independent states in the region, in particular the other former French colony, the Republic of Haiti, only conveys a cautionary message. That is the appropriate context to interpret the sigh of Claude Lise, President of the Martiniquan General Council when he asked: 'Can one balance off a level life GNP with a feeling of dependency?'49 


\section{The Comparative Context: Puerto Rico and the U.s. Virgin Islands, Deadlocks in American Geopolitics}

During World War II the United States started to force the European colonial powers to live up to an ideology of national self-determination and thus acted as champions of decolonisation. The Americans themselves were also faced with the problem of how to reconcile their relatively young empire with these political ideals. After all, since the beginning of the twentieth century the United States controlled a strategically situated empire itself, albeit of a more modest nature than those of its European counterparts. It soon turned out that Washington often pushed aside its ideologies on independence in favour of a more self-serving approach. The irony is that in several of the newly acquired American territories, reform and full decolonisation were late in coming or failed to materialise at all. 'Decolonisation' may have been an American concept right from the start, but its own colonial heritage was addressed with remarkably ambivalent solutions.

American policy for Puerto Rico and the U.s. Virgin Islands - the two current possessions in the Caribbean - corresponds neither to the pragmatic, economic approach of the British, nor to the French methods of full integration. Neither full independence nor incorporation as new federal states have been accomplished. Apart from economic considerations, arguably racial and cultural motivations guided Washington's reticence in the latter respect, particularly for Puerto Rico which, despite a century of attempts at Americanising 'Porto Rico', remains a predominantly Latin, Spanishspeaking culture. ${ }^{1}$ In 1947 the Americans stated that independence was beyond discussion and subsequently limited their concessions to granting Puerto Rico the right to draft its own Constitution in 1952. This reform would in no way be allowed to jeopardise the American military presence on the island. This 'transitory regime' proved to be infinite. The Cold War prevented any dialogue on the island's political status for three decades. Puerto Rico - and to a lesser extent the U.s. Virgin Islands - were rather destined to become a showcase of American development. ${ }^{2}$ Since then, there has been much discussion all through the 1990s about a possible change of status, yet this has not resulted in any decisions.

Both Puerto Rico and the U.s. Virgin Islands have been autonomous to some extent for half a century (since 1952 and 1954 respectively), but display considerable differences in constitutional status - the Virgin Islands functioning under a more restricted form of self-government. Their foreign policy and defence have remained in American hands, and economic de- 
pendence on the metropolis is considerable. Their residents are American citizens, and thus have the much valued right of abode on the continent; the number of Puerto Ricans and U.s. Virgin Islanders living in the United States is indeed very high. The special and materially privileged status of these islands has resulted in a rather isolated position within the region an isolation the American territories have in common with the rest of the non-sovereign Caribbean.

\section{The Commonwealth of Puerto Rico}

The Americans like to consider themselves standard-bearers of democracy; after all, following a bloody struggle during the latter quarter of the eighteenth century, the North Americans rid themselves of the British. As a result, the United States prided itself on being an anti-colonial nation - even though the Americans would persist in upholding the colonial legacy of African slavery for almost a century after their 1776 Declaration of Independence, and still confined to usurp territories, thus becoming a colonial power themselves. Alaska was purchased from Russia in 1867. Large parts of Mexico were occupied during the second half of the nineteenth century. Around 1900, Puerto Rico, Cuba and the Philippines were taken from Spain after America's self-serving intervention in the Cuban war of independence. ${ }^{3}$ In the same period the Sandwich Islands - in particular Hawaii, a former possession of the British - were annexed, along with Guam, the Eastern Samoa Islands and Wake. Central America was brought under an informal tutelage. Having established itself both in Latin America and in Asia, Washington considered the region of Panama to be of prime strategic importance. In 1903 heavy-handed diplomacy secured sovereignty over the intended canal zone. The jurisdiction of the United States over this zone would only be returned to Panama in 2000 .

Although there was little modesty in the geopolitical goals of the Americans, repeatedly Washington adopted a critical stance regarding European colonialism, referring, in doing so, to its own war of independence. ${ }^{4}$ In order to support the independence wars in Latin America, but equally to underline its own hegemonic claim to the 'New World', in 1823 Washington launched the Monroe Doctrine under the slogan 'America for the Americans'. Any new European imperialist adventure in the Americas could count on resistance from the federal government. In return Washington would condone the few remaining European colonies. But the Monroe Doctrine was not restricted to the Latin American continent. Special attention was paid to the Caribbean, which the Americans were beginning to consider their mare nostrum. The dogma of Manifest Destiny entrusted them with its guardianship 'by divine order'; the Caribbean was 'predestined' to come under the control of the United States. ${ }^{5}$ This conviction not 
only stemmed from a feeling of superiority. From the start American involvement in the region was based on the assumption that the Caribbean needed to be supervised carefully since any outside influence posed a potential threat to national security. As the Spanish-American war of 1898 would make abundantly clear, the Monroe doctrine served both as a nonintervention doctrine and as the ideological underpinnings of the American hegemonic role in the Western hemisphere. The Roosevelt Corollary (1904) re-emphasised this doctrine; regional intervention was justified by the sheer interest of American geographical position and political power. Thus the philosophy of guardianship easily turned into a mandate for American imperialism. This assertive geopolitical policy went hand in hand with an increasing economic hegemony in the region.

World War I led to a stepping up of the American military presence in the Caribbean. ${ }^{6}$ The new geopolitical context resulted in heightened interest in the region, mainly for security reasons. Geopolitical goals were formulated explicitly in terms such as 'dollar diplomacy'(for Haiti and the Dominican Republic, but also for Puerto Rico). The 'Good Neighbor Policy' (1933), as part of President Franklin Roosevelt's New Deal, decreased America's military presence in the region, but without diverging from the existing political line. All in all this bore little correspondence to the spirit of the famous 'Fourteen Points' drawn up by President Woodrow Wilson at the end of World War I. Perhaps partly due to this apparent ambiguity, American theories on worldwide national self-determination failed to have any immediate effect on European colonialism. Only following World War II would the European colonial powers - under pressure - become more receptive to American advocacy of self-determination.

At the outbreak of World War II, in the autumn of 1939, the United States initially stuck to its isolationist tradition with regard to world politics. With Japan's unexpected attack on the American naval bases at Pearl Harbor, on 7 December 1941, this rapidly changed: the following day America declared war on Germany, Italy and Japan. The U.s. participation would prove decisive in the outcome of the war. It would also have profound consequences for the Caribbean. The war ushered in a new phase of American military presence in the region, which previously had been limited to Haiti and the former Spanish colonies. With the consent of the British and Dutch colonial governments, American troops were stationed at several of their strategically important Caribbean colonies. ${ }^{7}$ There was also a longer-term engagement. With Winston Churchill, the Americans concluded a "basesfor-destroyers-deal'. In exchange for fifty torpedo-boat destroyers, the British government leased for 99 years a series of Caribbean naval bases to the Americans. U.s.-British military cooperation subsequently developed into an alliance concerned with the region's socio-economic development, institutionalised in the 'Anglo-American Commission for Caribbean countries' (1942), a first and actually short-lived attempt at multilateral coopera- 
tion in which France and the Netherlands would also briefly participate. ${ }^{8}$

During the war, it became clear that decolonisation would be among the future top priorities in world politics. In November 1942 the United States had laid down an anti-colonial position in a 'Declaration of National Independence for Colonies'. Washington would insist that all colonial powers set a deadline for granting independence to their possessions. Ironically, prior to the war, U.s. Congress had vetoed the Tydings Bill, which had proposed future independence for Puerto Rico. It was argued that continued full control over the island's military installations would be impossible should Puerto Rico become independent. ${ }^{9}$ The American dilemma of opting between a pro-independence stance and national interest had been clear in this case, and would become ever more conspicuous during the Cold War, when the United States deployed massive military power and actually fought fully-fledged wars in Asian countries after the European colonisers withdrew. The American dilemma was also becoming apparent within its own empire: while sovereignty was transferred to the Philippines in 1946, there was no inclination to give up the strategically more important territory of Puerto Rico. American politics at the time - whether dominated by Republicans or Democrats - urged for European decolonisation, but continued to picture the future role of the United States within the Caribbean not only in economic and geopolitical terms as such, but also in a perpetuation of its constitutional presence in the region.

At present the Americans still govern two Caribbean nations. ${ }^{10}$ While the U.s. Virgin Islands and Puerto Rico lie a mere 45 miles apart, they have widely divergent histories. After four centuries of Spanish control, Puerto Rico came under American sovereignty in 1898, a war trophy of the Spanish-American war mainly fought over Cuba. The Virgin Islands only came under American jurisdiction in 1917, when they were purchased from Denmark. Both new acquisitions were deemed of strategic value - it is telling that during the first decades of American rule the territories remained under Navy control.

When in 1898 the federal government took Puerto Rico over from Spain, little local protest was voiced. A strong independence movement remained absent - in stark contrast to its culturally similar 'sister island' Cuba. Upon the acquisition of Puerto Rico, Congress faced a political choice: shortly before the Spanish-American war it had passed a law stating that should any new territories be acquired, they would eventually become federal states of the Union. However, the possible annexation of 'non-neighbouring' territories with 'foreign' cultures had not been taken into account. From the beginning Puerto Rico was considered an 'unincorporated territory'; thus in 1900 the island was termed as 'belonging to but not part of the United States' ${ }^{11}$ During the 1920 a formal distinction followed between 'incorporated and unincorporated territories', with only the first category being destined to eventually become a state of the Union. Territories falling with- 
in the second category would remain American dependencies indefinitely. As it was ruled by the Supreme Court, Puerto Rico would thus continue as an unincorporated territory, 'on the grounds that incorporation was an important step towards statehood, and that Congress had no such intentions for the island'. ${ }^{12}$

The Jones Act of 1917 heralded a step forward in the field of self-governance, and the granting of American citizenship along with universal suffrage which it contained was received with some enthusiasm on the island. In contrast, the fact that American citizenship would not eventually lead to 'statehood' and could unilaterally be revoked by Congress, as well as the stipulation that Congress maintained sovereign power over the people and territory of Puerto Rico, were considered a grievous blow by many Puerto Ricans. Yet it was widely believed that it would only be a matter of time until this 'transitory phase' would end in statehood. ${ }^{13}$ The Act of 1917 did offer economic advantages. Apart from free trade to the American continent, the Puerto Ricans were granted exemption from federal taxes; customs duties on imports would solely benefit the island treasury, as was the case with all excise charged on Puerto Rican goods sold in the continental U.s. As a result, the island's revenues would expand greatly. Roosevelt's New Deal of the 1930s, which in reaction to former laissez-faire policies propagated a strong economic role of the state, also stretched to Puerto Rico, but yielded little effect in the long run. ${ }^{14}$ It would take another decade before a second and stronger phase of state intervention would be applied.

As early as 1922, the idea of an associated free state had been presented to Congress; it would, however, take another thirty years before the decolonisation process of Puerto Rico would formally end in the present associated status. ${ }^{15}$ The first tentative steps on this path were only taken following World War II. In 1946 the island would see the first Puerto Rican native hold the office of Governor, which was followed by the decision, in the following year, that the Governor would be locally elected. ${ }^{16}$ In the same year Puerto Rico was granted a larger degree of autonomy, and in future all cabinet members were to be appointed by the Governor rather than by the American President. ${ }^{17}$ A further modernisation took place in 1950, when Congress approved of a bill proposed by the 'Resident Commissioner' Puerto Rico's representative in Congress - for a reorganisation of the island's administration, and in particular to allow Puerto Rico to lay down its own Constitution. The bill was passed by Congress as 'Public Law 6oo', with the goal 'to allow the people of Puerto Rico to organise a government pursuant to a Constitution of their own adoption'. Even so, this Constitution would remain 'subject to Congressional review. ${ }^{18}$

Public Law 6oo, with the nature of a compact between Congress and the Puerto Rican people, was a cornerstone in the political status of the island. In February 1952 a Constitution for a self-governing Commonwealth was formulated, much along the same lines as the American Constitution. Soon 
after it was approved by local plebiscite - with an estimated turnout of 67 per cent, no less than 70 per cent voted in favour. ${ }^{19}$ Clearly by a large majority the Puerto Ricans had voted for association. This was reconfirmed in a resolution of Puerto Rico's Constitutional Assembly, which defined the Commonwealth status as a 'rejection of separation; an assertion that the Commonwealth status "is a status in itself which fulfills the highest ideals of freedom and human dignity and which is dynamic in its potentialities for growth; $[. .$.$] and the declaration that common citizenship and common$ defense were the essential bases of association". ${ }^{20}$ In July 1952 Congressional confirmation followed, albeit under three conditions - all of which were accepted by the Puerto Rican Constitutional Assembly - including the stipulation that local laws should conform to the requirements of the U.s. Constitution. Control over the island had - and has - ultimately remained with the United States.

On 25 July 1952, precisely fifty-four years after the first American troops had landed on the island, the new Constitution was promulgated and the 'Commonwealth of Puerto Rico', or the Estado Libre Asociado (ELA), came into being. Only the small minority party of independentistas had refused to participate in the preparations. ${ }^{21}$ Under the new status Puerto Rico became autonomous in its internal affairs; a 'locally self-governing unincorporated territory under Congressional jurisdiction'. The Puerto Ricans maintained their American citizenship, free trade with the continent, and exemption from all federal taxes. The island was now an associated state in the sense that it was legally bound to the federal government in a relationship founded on a communal agreement which, nevertheless, could be amended unilaterally by Washington: 'Constitutionally, Congress may repeal Public Law 6oo, annul the Constitution of Puerto Rico and veto any insular legislation which it deems unwise or improper. ${ }^{, 22}$

In 1953 the meaning of the new relationship was discussed in a lengthy debate within the United Nations. Critics questioned whether Puerto Rico was indeed autonomous as it remained subordinate to military legislation and its defence lay in American hands. Eventually the Commonwealth status was given the benefit of the doubt by the majority of U.N. members, with emphasis being placed on the nature of the compact, namely a 'mutually agreed association'. ${ }^{23}$ Accordingly, in November 1953, the General Assembly adopted a resolution in which it was recognised that under the compact 'the people of the Commonwealth of Puerto Rico have been vested with attributes of political sovereignty which clearly identify the status of self-government attained by the Puerto Rican people as an autonomous political entity'. ${ }^{24}$ That the American delegate to the United Nations explicitly confirmed the option of future independence may have helped: should the Puerto Rican Constitutional Assembly ever vote in favour of independence, then the President would not hesitate to grant this status, so he said. ${ }^{25}$ Apparently the Americans were confident it was safe to be forthcom- 
ing in this respect and that U.s. strategic interest would not be affected. After Fidel Castro came to power, Cuba would become one of the fiercest critics of the Puerto Rican status. In 1972 the U.N. would state that Puerto Rico 'had not yet attained independence' and recognised its 'inalienable right to self-determination and independence. ${ }^{26}$ Yet neither Washington nor San Juan seemed to take any of this very seriously.

\section{Puerto Rico’s Status Debate}

Although Puerto Rico's Constitution was at the time among the more progressive in the Caribbean, the degree of autonomy was rather limited even the late-nineteenth-century Spanish Carta Autonómica had been less restrictive. Not only were foreign relations and defence excluded from the island's competences, but also jurisdiction over military bases and army activities $^{27}$, military regulations, the establishment of enterprises and customs duties, monetary policies, citizenship, the regulation of immigration and aliens, postal services, control over internal and external communications and the compulsory use of American freighters. Most federal laws remained applicable in Puerto Rico and, as stated above, unilaterally Congress could amend the Commonwealth construction.

During the following decades both the independentistas and advocates of statehood clearly stated that they considered the new Constitution nothing but a continuation of colonial status. 'Statehooders' argued that American citizenship without being part of the federal Union only imbued secondclass citizenship. For the independentistas, who also called for demilitarisation of the island, independence was the only acceptable outcome. Yet the Puerto Rican electorate, well aware of the many inherent advantages, thus far has never supported a breach with the United States. Its conservatism in this respect has been inspired by the major advantages of the status: a U.s. passport and the right of abode in the United States for all Puerto Ricans, and massive economic assistance. The most significant change in attitude among the Puerto Rican electorate would be a gradual decrease of enthusiasm for Commonwealth and a concomitant but so far inconclusive increase of support for full statehood; this trend first became apparent in the 1967 plebiscite, when 39 per cent opted for statehood and a mere 0.6 per cent for independence. ${ }^{28}$

At the outbreak of World War II Puerto Rico had been poor - largely due to overpopulation and the island's primary dependence on sugar production - and was even refered to as 'the overcrowded poorhouse' of the Caribbean. In the beginning of the 195os, under the leadership of Luís Muñoz Marín, the architect of the Commonwealth system, a course of rapid industrialisation was set in motion. 'Operation Bootstrap' was based on attracting American enterprises via a programme of 'industrialisation 
by invitation'. American companies establishing themselves on the island were exempt from paying federal and local taxes for a ten-year period and given access to cheap labour. In return, they needed to transfer three per cent of their capital investments to the island treasury. Meanwhile the United States lowered most barriers to regional trade. ${ }^{29}$

Operation Bootstrap would succeed on the one hand, bringing many labour-intensive industries to the island and securing many years of strong economic growth; the Puerto Rican model was advanced as a shining example for the region, particularly as against revolutionary Cuba..$^{30}$ On the other hand, the situation was anything but rosy. Urbanisation led to an exodus from the countryside, structural unemployment at times reaching three times the national average, a dramatically increasing emigration to the United States, and growing economic dependence on American multi-nationals and federal support. Operation Bootstrap also strengthened the island's one-sided orientation towards the United States and thus increased this isolation within its Caribbean surroundings.

By the mid-197os the wonders of Operation Bootstrap had definitely waned and Puerto Rico found itself in trouble economically. Increased labour costs incited many companies to leave for newer, cheaper locations. Puerto Rico became more directly dependent on federal transfers. Washington intervened with a new tax law, once again intended to attract American companies to Puerto Rico. Lured by the advantages of 'Section 396 ' of the International Revenue Code, mainly high-tech and pharmaceutical enterprises were now drawn to the island. These industries would have very limited effect on local employment. Despite a new phase of economic growth, the development of the island's infrastructure remained woefully inadequate, with a distorted distribution of wealth - around sixty per cent of the population is dependent on food stamps today - and the related problem of mass emigration. To make matters worse, Congress decided to withdraw Section 396, since the cost to the treasury was deemed too high. The Puerto Rican Resident Commissioner in Washington only provisionally convinced Congress of the need to continue the tax advantages: in May 1996 a ten year phase out of Section 396 began. ${ }^{31}$ At the turn of the century, the island was heavily dependent on U.s. federal support, amounting to no less than $\$ 2,500$ per capita - over 75 per cent of these transfers directly destined for 'Transfer Payments to Individuals'. The soaring of these costs from us $\$ 4.5$ million in 1985 to $\$ 9.5$ million at the end of the century, is a major bone of contention in Washington, not only because of the cost involved, but also because these transfers reflect a protectionist relationship awkwardly at odds with the neo-liberal ideology of the 1990s. ${ }^{32}$

Within the Caribbean, Puerto Rico has an isolated position. The island may be poorer than the poorest federal state, but economic conditions are more favourable than those in the region. Yet its isolation also has a politi$\mathrm{cal}$ and cultural dimension. Neighbouring states tend to view the island 
merely as a subordinate of the hegemonic power in the region. This virtually rules out Puerto Rico from successfully playing a regional role. ${ }^{33}$ Adding to this is the ongoing status debate on the island, revolving around a possible further incorporation into the continental United States rather than future independence. ${ }^{34}$ The economic crisis of the 1970 and 1980 s had also given a new impulse to the advocates of statehood. Incorporation into the Union was seen as a chance for increased federal support, especially when under President Ronald Reagan's Caribbean Basin Initiative (1984) a wide range of Caribbean states began to receive advantages which until then had been reserved for Puerto Rico. ${ }^{35}$

In recent decades Washington has adopted an ambivalent stance in the status debate. In the Puerto Rican Statehood Act of 1977 it was laid down, on the initiative of the then President Gerald Ford, 'that the appropriate status for the Commonwealth of Puerto Rico is statehood and that the people of Puerto Rico should be able to achieve this status under the Constitution of the United States if they should so desire'. ${ }^{36}$ With this, for the first time ever, an American president was prepared to back the issue and even favoured an option that had thus far never received any meaningful support in Congress. In 1989, President George Bush - a Republican like Ford declared in his inaugural speech support for statehood, and called for a status referendum. ${ }^{37}$ This did not materialise: after two years of Senate hearings (the referendum was planned for the Summer of 1991) the responsible Senate Committee rejected the bill since it required Congress 'to vote on legislation carrying out the will of Puerto Rico, as expressed in the referendum'. At the time there was strong support on the island for statehood. ${ }^{38}$

While the American Congress and Senate continued to consider possible changes for Puerto Rico without reaching any firm conclusions throughout the 199os, the issue was all the more fiercely debated on the island itself, both under pro-Commonwealth governor Rafael Hernández Colon (19841992) and under his pro-statehood successor Pedro Rosselló (1993-2000). In 1993 another referendum was organised and conducted by the Puerto Rican government, with no American involvement. Neither statehood (46.3\%) nor the Commonwealth option (48.7\%) enjoyed a clear majority; compared to the results of 1952 and 1967, however, the system of Commonwealth had lost support. Independence scored a mere $4.5 \%$. Over the next five years Congress would again leave unresolved the issue of organising a federally sponsored referendum. Eventually the Senate would acknowledge, in September 1998, the island's right of self-determination, while reconfirming that the federal government would maintain ultimate sovereignty over the island and determine its status. ${ }^{39}$

In the end the Puerto Ricans held another locally prepared referendum in 1998 - coinciding with the 100th anniversary of Puerto Rico's invasion by the United States. Statehood received $46.5 \%$ of the votes, disappointing the reigning pro-Statehood PNP which had hoped finally for a majority. With 
2.5\%, independence as always found little support. Unlike previous plebiscites, this one did not produce significant support for the still reigning model of Commonwealth. Rather, a slight majority refused to take any of these three options and voted 'none of the above' instead (50.1\%). The pro-Commonwealth PPD, in protest against the nature of the 'Commonwealth' as defined on the ballot - i.e. as an unincorporated territory and not, as the PPD had wanted, as an enhanced model of permanent association with the United States in which the island would share many rights of an independent state - had encouraged the electorate to vote for 'none of the above'. The results of the vote thus remained open to debate, with both the statehood and the pro-Commonwealth parties claiming victory once again..$^{40}$

The question of Puerto Rico's political status thus remains unresolved. Support for the present status has been waning, but statehood has not found a majority either. Opponents of statehood argue that with Commonwealth - and particularly the enhanced version they strive for - the island can enjoy the best of both worlds, and emphasise the presumed economic disadvantages of statehood (more federal taxes, less personal income) as well as the cultural differences between Puerto Rico and the United States. They argue that as Puerto Rico is a country with a Latin heritage, it is by nature not destined to become a federal state; most American parliamentarians speaking out about this issue have indeed confirmed they cannot accept an uncompromising Latin culture as a new federal state..$^{41}$ The PPD therefore argues that Puerto Rico should instead develop its unique bridging function between the United States and the Caribbean and Latin America, both economically and culturally. These arguments, coupled with justified doubts regarding the question of whether Congress would in fact ever be prepared to admit Puerto Rico into the Union, apparently have led many Puerto Ricans to conclude that statehood is not a realistic option. ${ }^{42}$

Advocates of statehood in turn also base their position on ideological and economic arguments. The biggest stumbling block for the statehooders is that currently, Puerto Ricans are treated as second-class citizens. They take issue with the fact that federal laws of a general nature are applicable in Puerto Rico, but the Puerto Rican people have no say at all in the formulation of this legislation - not even the Resident Commissioner has a vote in Congress. They further object to the fact that Congress may intervene in the internal affairs of Puerto Rico, while the Puerto Ricans have no right to unilaterally amend their Commonwealth system. ${ }^{43}$ Basically, advocates of statehood believe that the Commonwealth status has failed to deliver solutions, and instead has introduced a lengthy and paralysing state of insecurity on the island. With regard to economics they argue that federal states continue to grow stronger and are more prosperous than external territories. Statehooders believe therefore that incorporation into the United States will give an impulse to the island's economy, along with increased 
federal support, including social benefits on the same level as those in the continental United States. Beyond that, statehood will definitely secure the perpetuation of American citizenship. ${ }^{44}$ Finally, the advocates of statehood use the political argument that after half a century of a transitory phase, the Puerto Ricans are now ready for full integration since the political, legal and financial systems of the island are firmly cemented in American political traditions.

For the small minority advocating full independence, the core of their argument lies in the inherent cultural and political divergence. Puerto Rico, as they emphasise, is the only part of the former Spanish empire in the New World which is yet to reach sovereignty. For the independentistas any solution falling short of full independence represents a continuation of the colonial relationship and an insurmountable obstacle to genuine development. They fiercely denounce the American military and strategical exploitation of Puerto Rico. As for the economic relation, they maintain that both American protectionism - high tariff walls, privileged access to the island for American companies - and the massive transfer of federal subsidies deepen the island's economic subjugation to the United States. They also argue that anything less than full independence is at odds with American democratic ideals. However, in Puerto Rico there is little support for this opinion. As Gordon K. Lewis, a vehement critic of American policy, wrote: 'What, in fact, has happened is that America throughout has confronted the island population with a Hobson's choice between a political status that gives them food with shame or one that offers them poverty with dignity. 45

Meanwhile, the in the end decisive American point of view is no less ambivalent. For much of the twentieth century Puerto Rico was not considered suitable for incorporation as a federal state, a refusal partly reflecting the distrust and contempt embodied in the ideologies of the Monroe Doctrine and Manifest Destiny. For the United States, Puerto Rico represents strategical advantages, yet American policy makers have seen mainly liabilities in the fields of economic relations, cultural traditions and migration. One wonders what is more significant in this perspective: the fact that over the past quarter of a century several Republican presidents have spoken out in favour of statehood, or the fact that this has never led to any concrete legislation. In the end, the fact that full statehood remains (at least in theory) a genuine option seems due to pragmatism rather than to an increased sense of solidarity of Americans with Puerto Ricans or vice versa. The United States, so it seems, is in no hurry, content with the strategical advantages of having an outpost in the region, worried over the soaring costs of federal transfers yet only mildly frustrated by the awareness that for all of Washington's rethoric, administrative effort and money deployed, Puerto Rico remains an island of its own, where American hegemonic power has failed to turn the former colony into a truly American state and to break the dead- 
locks which have characterised U.s.-Puerto Rican relations over the past century.

\section{The U.s. Virgin Islands: Unincorporated Territory}

With 3.8 million inhabitants, Puerto Rico has a significant population, certainly in a Caribbean perspective and particularly when focusing on the group of non-sovereign territories in the region. All others in this group have a population of less than 400,000 , most individual islands even have less than 100,00o inhabitants. This also applies to the the second American territory in the Caribbean, the Virgin Islands. The total population figure of this archipelago amounts to some 110,ooo inhabitants, spread over three main islands, St. Thomas, St. John and St. Croix.

Once flourishing centres of slave trade and sugar-producing slave colonies, the islands had become an economical burden to Denmark by the nineteenth century. The small European metropolis neglected the islands. Washington decided to purchase the archipelago during World War I mainly for strategical reasons, but also in a bid to prevent German possession of the islands. The transfer to the United States saw wide spread support from the vociferous sections of the local, Anglophone population. The islands were initially designated unincorporated territory, like Puerto Rico, and were placed under the jurisdiction of the federal Navy Department. The Fleet Admiral appointed by the American President also acted as Governor. Remarkably, Danish colonial legislation would largely remain effective until 1936. The residents of the U.s. Virgin Islands became American citizens in 1927. As of 1931 Navy control of the Virgin Islands was substituted by the jurisdiction of the federal Department of the Interior. In the same year, the first civilian Governor was appointed. ${ }^{46}$

The U.s. Virgin Islands, prior to their annexation in 1917 by the Americans, had had virtually no experience of self-government. It would be a further nineteen years before Congress, in reaction to local dissension with the authoritarian administration and economic malaise, would make way for the 1936 Organic Act, granting the islands universal suffrage and a measure of self-government. Progress towards a more representative form of government was only partial: the President could still veto local legislation and continued to appoint the Governor. The population calmly accepted the new administration. Apparently there was an expectation on the islands that this arrangement would yield economic advantages and so should not be put at stake by any desires for far-reaching constitutional or political change. In fact, when the population was given the choice, in 1948, to elect its own Governor, this offer was rejected since it was generally felt that an appointee of the American President would have more voice in Congress than any local candidate. ${ }^{47}$

A first post-war change in the islands' administrative structure was the 
Revised Organic Act of 22 July 1954 which introduced a broadening of autonomy and the first popularly elected legislature. The Act left the U.s. Virgin Islands' status as an 'organized, unincorporated territory of the United States' unamended since they stayed under the full sovereignty of Congress. The nature of the 'special relationship' with the United States remained unchanged, with federal legislation still locally applicable and the Presidential veto over local legislation in tact. Under the Act the competences of the Governor (at the time still an appointee of the President) were extended in the field of finances; he also retained the right to annul local legislation. Clearly Congress strove to avoid the interpretation of this Act as a step forward on the path to full integration as a federal state. ${ }^{48}$ The 1954 Act, which is still in effect today, was primarily aimed at enlarging the efficiency of government and the prevention of fraud and abuse within the local administration. The former structure of two municipal administrations beneath a territorial government had played a part in the emergence of corrupt financial practices - in any case, Washington deemed this construction unnecessarily expensive and elaborate for a population of less than 100,000 people at the time.

The local Constitutional Convention of 1964 allowed the island's population to speak out on the political future of their country. Several reforms were proposed in order to amend the 1954 Organic Act. In one resolution annexation by the Americans was denounced, while in another independence was rejected. The Convention adhered to a continuation of the existing - unincorporated - status and the special relationship with the United States, albeit with a request for a greater degree of autonomy. ${ }^{49}$ During subsequent years Congress gradually introduced reforms in the islands' administrative structure, partly due to pressure from the United Nations. In 1971 the first popularly elected Governor was inaugurated. Two years later, in 1973, Washington granted the longstanding wish for an elected Resident Commissioner in Congress, just like Puerto Rico has. ${ }^{50}$ In the same year the presidential veto of local legislation was abolished, although this veto continues as a prerogative of Congress. In 1976 the Virgin Islanders received the right to draft their own Constitution, if only under the Congressional stipulation that this needed to conform to 'the existing territorial-federal relationship, ${ }^{51}$ In actual fact the island is still waiting for a revised Constitution - so far there have been five attempts, aimed at broadening local autonomy, but none of the Constitutional proposals have entered implementation stage..$^{52}$ Their failure can be closely linked to local dissensus - every time the proposals for revision of the status quo reached referendum stage, they were rejected. The reason for this may well lie in the uncertainty surrounding the long-term effects of any change for the islands' economy. The American government has pronounced that reforms are acceptable only as long as they have been approved by the people, are economically viable and do not jeopardise American national security. 
Ever since 1954 the United Nations has insisted that Washington take the appropriate steps in giving the islands' population the opportunity to express its wishes regarding the political status without any external interference. At the end of the 1970 s the first U.N. mission in twelve years was allowed to visit the islands. By August 1983 the U.N. Decolonisation Commission would still continue to insist that 'the United States speed up the process of granting independence to the U.s. Virgin Islands' ${ }^{53}$ Objections were also specifically aimed at America's military installations on the islands. According to the United Nations this military presence makes any form of successful self-government impossible right from the start. In response to these allegations, the Americans have been insistent that the U.N. Charter does not prohibit the establishment of military installations in 'non-self-governing territories' and that 'the maintenance of such bases is a sovereign right of nations deriving from their obligation to defend their territory and their nationals' ${ }^{54}$ Nevertheless, in U.N. quarters the development of the U.s. Virgin Islands was still considered 'unsatisfactory' in the early $1990{ }^{55}$ The result is that today, the islands still figure on the U.N. List of Non-Self-Governing-Territories.

The U.s. Virgin Islands are relatively prosperous and self-supporting. They are aided by various technical assistance programmes. The total aid approximates $\$ 1,000$ per capita. ${ }^{56}$ Tourism is the primary economic activity, accounting for more than seventy per cent of GDP and seventy per cent of employment. The agricultural sector is small, with most food being imported. International business and financial services are a small but growing exponent of the economy. Unemployment is very low, at around four per cent. ${ }^{57}$ Beyond that, the multi-party system functions in a stable political climate. In spite of U.N. criticism, constitutional matters seem of little importance either to the local population or to the United States. In contrast to Puerto Rico, political status is not an issue on the islands. This goes some way in explaining the outcome of the 1993 status referendum, in which a mere 27.5 per cent of the electorate voted. Of these, 80.4 per cent voted for continued or enhanced territorial status with the United States; 13.2 per cent opted for complete integration with the United States, while 4.9 per cent chose the 'removal of United States sovereignty'. Because of the low turnout, the referendum had little impact on the status issue, suggesting that most inhabitants of the islands had other priorities higher on their list. ${ }^{58}$

Puerto Rico's Commonwealth status and the position of the U.s. Virgin Islands as an unincorporated territory have become a firm part of the fabric of their societies, and at least the refusal to become independent is regularly confirmed in referendums. The explanation for the populations' relative contentment with subordination to the United States lies in the inherent and substantial economic support and political stability they enjoy, as well as in the possession of American citizenship and the right of abode in the 
metropolis. Therefore, from the pragmatic islanders themselves no breach with the United States is to be expected. Beyond that, unlike London and The Hague, Washington has never insisted that its Caribbean territories accept independence - in fact the opposite is true. Just like France, the United States has consistently defined its Caribbean policies by geopolitical considerations; and just like Paris, Washington has been prepared to invest significantly to this end. The serious increase in immigration from the islands to the continent has not really changed this attitude. Today the main question is whether Washington would also be prepared to fully incorporate Puerto Rico as a new state into the federation, despite the prognosed extra financial burden and the undiminishing cultural gap separating the island from the United States. ${ }^{59}$ For the U.s. Virgin Islands statehood is highly unlikely and Congress has never seriously considered the option of a Commonwealth status. Cautious statements on the broadening of the islands' autonomy seem as far as Congress is prepared to go.

Thus these American territories in the Caribbean share the fate of their French and British partners in the region, enjoying appreciable benefits at the expense of political subordination, while experiencing the ambivalence inherent in this post-colonial relation. In the following chapters, we will analyse the divergent trajectories of the former Dutch Caribbean colonies, with Suriname in the end opting for a costly independence, the Netherlands Antilles refusing to accept that challenge and hence today enjoying the same benefits but struggling with the same ambivalence as the rest of the non-sovereign Caribbean. 


\section{Dutch Rule in the Caribbean up until 1940: Careless Colonialism}

The manner in which the Dutch decolonisation process was handled is commonly regarded as leaving a lot to be desired. The Netherlands suffered the loss of Indonesia, despite long negotiations and military actions; the intended 'model decolonisation' of Suriname was never achieved and the attempts to grant independence to the six islands of the Netherlands Antilles as a whole were in vain. Now, at the beginning of the twenty-first century, the Kingdom of the Netherlands still includes two Caribbean countries, the Netherlands Antilles and Aruba: islands that still feature regularly, and unfortunately, to a large extent, in a negative context in the Dutch media.

\section{Failed Exploitation}

The Dutch presence in the Caribbean is the fruit of a long colonial past. A short outline of previous colonial history is necessary for clarification of the present situation. In the eighteenth century the Dutch colonial domain extended from Asia in the East, with its trade centres and the vast archipelago of the Dutch East Indies, through Africa with the Southern Cape Colony and its inland trading centres, to the Americas with Suriname and its neighbouring colonies of Berbice, Demerara and Essequibo and the six Antillean islands (Curaçao, Bonaire, Aruba, St. Martin, St. Eustatius and Saba). In the seventeenth century, previously conquered colonies in the Americas, New-Netherlands and northeast Brazil, had already been lost to England and Portugal respectively.

During the Napoleonic wars, the Dutch colonial realm 'temporarily' came under British administration. Only the East Indies, Suriname and the Antillean islands were returned to Dutch authority around 1815. During that time the Dutch East Indies - not without reason colloquially called the 'Dutch Indies' - formed the major colonial possession. The territories in the Caribbean were smaller, less populated and held less economic potential. Mainly because of this, colonial policies here were rather uninspired and fairly inactive. In turn, the absence of an energetic and visionary approach by the Netherlands contributed greatly to the failure of the West Indian territories to ever rise above the status of 'poor cousin' to the Dutch East Indies.

Suriname was developed as a plantation colony. A steady stream of Euro- 
pean colonialists and enslaved Africans populated the country; in the eighteenth century slaves constituted more than ninety per cent of the population. As everywhere else in the Caribbean, it did not take long before the native people had almost completely died out, or had been banished to the margins of the colony. The natural environment of the Antilles did not lend itself to development as a plantation colony. Instead, the Dutch islands, Curaçao and St. Eustatius in particular, fulfilled a vital function as points of connection for trade - both legal and illegal - within the Caribbean region. The islands were populated by a minority of free Europeans and a majority of African slaves. During this period Aruba - a 'dependency' of Curaçao adopted a more separate status; the island was populated by a mestizo, Indian-European people with relatively little African presence and remained rather isolated from the rest of the Antilles.

Characteristic of the absence of a firm metropolitan vision of colonial rule in the West Indies, until the end of the eighteenth century each territory had its own administrative relationship with the Netherlands, or rather with - as it was then - the 'Republic of the Unified Netherlands'. Whereas the plantation colony of Suriname was administered by the 'Chartered Society of Suriname' of which the city of Amsterdam, the West India Company and the heirs of the first Governor of the colony, C. van Aerssen van Sommelsdijck, were members - the six Antillean islands were directly and exclusively managed by the West India Company.

In 1815, after the Napoleonic wars and the French occupation of the Low Countries, the Republic was succeded by a Kingdom. Thereafter colonial rule was placed under the direct control of the first King, Willem I. The King made attempts at a more effectual colonial policy. In view of the differences and big geographical distance between the territories, he immediately split the Caribbean possessions into three: Suriname, Curaçao 'and dependencies' (Bonaire and Aruba), and St. Eustatius 'and dependencies' (St. Martin and Saba). As this attempt failed to bear fruit, in 1828 the colonies were reunited as a single administrative unit run by a Surinamebased Governor-General. Again this was to no avail, due to the wide gap separating Suriname from the islands. The Caribbean possessions were split up once more, this time into two colonies: Suriname and the Netherlands Antilles. Until 1948 the latter would be referred to as 'Curaçao and dependencies'.

Meanwhile, in The Hague, colonial policy became increasingly institutionalised. In 1834 a Ministry of Colonial Affairs was founded, including a department for the East Indies as well as, from 1857, a desk for the territories in the West Indies. In 1848, with the introduction of the system of ministerial responsibility, the final say in colonial matters was transferred to parliament to which the minister of Colonial Affairs was answerable for his policies. In the course of the following century - up until the outbreak of World War II - the Ministry continued to develop. However, the West Indi- 
an department or, from 1918, the 'Department for Surinamese and $\mathrm{Cu}$ raçaoan Affairs' remained of minor importance.

During the course of the nineteenth century the Dutch East Indies became an essential contributor to the Dutch treasury, while the West Indian colonies almost constantly were a liability. The Surinamese budget showed a continuous deficit; this was also the case in the Antilles, at least until the 1930s. Therefore, all along, the Dutch government's primary concern was with reducing financial loss. Only rarely would confidence in the economic potential of the Caribbean colonies prevail. This blinkered view became poignantly clear with the conclusion of an issue that forms an absolute low in colonial history: the slave trade and slavery. Since 1600 Dutch merchants had brought an estimated half a million Africans as slaves to the shores of the New World. It was not until the beginning of the 185 os that the Crown, the Ministry of Colonial Affairs and the Dutch parliament came to recognise that the institution of slavery could not be upheld much longer - if only because it made the Netherlands look increasingly backward. Even though this was the first occasion that the Dutch government had become seriously concerned with its West Indian colonies, it would take another ten years before slavery was finally abolished in 1863 - long after England (1834) and France (1848) had taken this step. This was mainly due to the thorny problem of the compensation to be paid - to the slave owners, that is, not to the slaves.

From the Dutch point of view, the Emancipation of 1863 did not bring a change in the unsatisfactory economic development of the Caribbean colonies. To the great indignation of the white Antillean elite, at the end of the nineteenth century Dutchmen were quite regularly suggesting that the islands should be sold, since these colonial possessions only yielded costs instead of benefits. In 1869, a member of parliament observed that 'it is an easy life, living at someone else's expense', a sarcastic comment, the sentiment of which was to be repeated many times until the present. In 1930 members of parliament openly contemplated the option of transferring Suriname to another state. The trick had been pulled before: in 1911, Denmark had sold its Caribbean islands to the United States, hence giving birth to the U.s. Virgin Islands. ${ }^{1}$

In Suriname colonial policy was mainly aimed at supporting plantation agriculture. Not surprisingly, the freed slaves and their descendants showed little gusto for continuing their work on the plantations. Therefore the Dutch government organised a second migration wave to Suriname indentured labourers, initially from British India, followed by Javanese. After serving their contracts, most of these Asian immigrants settled permanently in the colony. In this way, and quite unintentionally, the Dutch government itself laid the foundations for an ethnic pluriformity which would have far-reaching consequences for the subsequent decolonisation process in Suriname. 
After World War I the economic profile of both colonies changed. In Suriname the plantation economy made way for small scale agriculture, and American business took the initiative to develop a bauxite industry which, from World War II onwards, would rapidly gain importance. Initially these changes still gave little comfort and the colony remained povertystricken. It was not by chance that in 1935 Minister of Colonial Affairs (and later Prime Minister) Hendrik Colijn complained in the Dutch Senate: 'Everything that has been tried in Suriname has all simply failed. Indeed things are not easy. And that is why I would like that for once in the Netherlands someone would stand up who does know what could be done. ${ }^{2}$ From the forties until the eighties there was more room for optimism, but after that period Colijn's pessimism has frequently been reiterated.

The economic development of the Netherlands Antilles, on the other hand, gained momentum in the period between both World Wars, through the establishment of oil refineries on Curaçao and Aruba. Again the initiative was not a Dutch one, although the choice of these locations by Shell and Esso was in fact related to their colonial status. Being part of the Dutch Kingdom, the islands counted as stable and secure investment areas, unlike the notoriously unstable republic of Venezuela, which provided the crude oil processed on the 'Dutch' islands situated just a stone's throw from the Latin tierra firme. From the thirties - and as it turned out until the midfifties - the Antilles would develop a level of prosperity exceeding not only regional standards, but also the Dutch one; the islands even contributed to the Dutch treasury. This was in stark contrast to Suriname.

\section{Colonial Administration}

Up until the outbreak of World War II the administrative relations between the Netherlands and its Caribbean territories remained colonial, mainly based on agreements made almost a century earlier. In 1865 - eleven years after a 'Regulation for the Dutch Indies' had been realised - Suriname and 'Curaçao' had been given administrative regulations. According to the explanatory document, these new regulations were aimed at 'guaranteeing a more generous level of autonomy and self-rule'. However, in actual practice, this autonomy appeared rather theoretical since, whenever the overseas budgets were not balanced, the Dutch parliament retained the right to either reject or adapt them. The Surinamese budget was not balanced until 1940, the Antillean one only since the 1930s, so that The Hague continued to determine almost yearly both overseas budgets in great detail. Moreover, under the 1865 regulations the local powers of the Governor, appointed by The Hague, remained large. Not only did he control executive powers, he also possessed a legislative monopoly, including the ability to veto any proposal by the Colonial Council and to carry through any decision of his own. 
Whilst in some ways meaning a step forward, these governmental regulations certainly did not introduce a representative parliamentary system in the Dutch West Indies. This situation was upheld until after World War II. In the meantime, only minor reforms were implemented. For example, according to the Constitution of 1922, the expression 'Colonies and Possessions in other Continents' was changed into 'the Dutch Indies, Suriname and Curaçao', whilst the regulation of 'internal affairs' in the territories was to be handed over 'to locally established institutions, the manner of which to be laid down by law, unless according to the law the right to regulate certain subject matters or in certain cases has been reserved by the King. Hence, the Governor remained the pinnacle of colonial administration.

Not until 1936 were Suriname and the Netherlands Antilles given new statutory regulations in which the measure of internal autonomy was generally broadened (again eleven years after this had happened in the East Indies in 1925). For the first time in history, a largely elected local Council was founded in the Antilles, the 'Staten of Curaçao'; in reality, no more than approximately five per cent of the local population became enfranchised. In Suriname, however, a reverse development took place and the previously abolished institute of appointed membership of the 'Colonial Council' was reintroduced. ${ }^{3}$ Thereafter in Suriname only half of the Council members would be elected, by way of a very limited census and capacity suffrage. The underlying - certainly justifiable - thought behind these measures was to guarantee the presence of (appointed) Asian representatives in the Colonial Council. Apart from that, in Suriname as well as in the Antilles, the new regulations still embued the Governor and not the local Councils with decisive competences. The Governor no longer needed to 'strictly' carry out the King's orders; it would be sufficient to administer the colony in accordance with the King's 'instructions' instead. Moreover, under the 1936 regulations, the Governor was in no way answerable to the local Councils; his powers to override this body in special cases had in fact been widened.

Thus in 1940, on the eve of World War II, Suriname and the Antilles were still administered according to traditional colonial practice. The half-hearted reforms that had taken place had initially been introduced in the East Indies and had predominantly been intended for that more important part of the Dutch empire. In the Caribbean territories, autonomy and a representative parliamentary democracy remained out of the question. Not only did the Governor receive his instructions from The Hague, but the local Councils - the Staten - lacked any legislative powers and were not in the slightest way representative themselves. These bodies lacked the capacity to force the Governor's hand in any way and had no influence over his position.

In every respect the East Indies were more important to the Netherlands than the West Indies would ever be, not only in the economic sense but also in the geopolitical sense. Around 1940 Indonesia numbered seventy million inhabitants and the Netherlands almost nine million, whereas Suri- 
name had only 140,00o inhabitants and the Antilles 108,ooo. In the period following World War II, the importance of the East Indies drove the Dutch government to extreme measures to retain its colonial realm. In this process Suriname and the Antilles would be spectators on the sideline, growing increasingly impatient but - as can be concluded afterwards - also profiting from the far-reaching concessions made in vain to the East Indies; concessions which prior to 1940 would have been inconceivable and through which the Caribbean territories would be able to benefit.

\section{Cultural Divides}

The cultural relationship between the different territories and the 'mother country' presents a paradoxical image. In Indonesia, with its predominant indigenous population, the influence of the Dutch language and culture remained limited to a thin upper layer of society, even though a relatively large group of Dutch people settled there. This colonial 'elite' experienced 'Our East Indies' as an essential part of the Dutch realm - as did increasingly broader layers of Dutch society. ${ }^{4}$

The relationship to the West Indies was very different, even if Surinamese spokesmen enthusiastically declared, without much exaggeration, that their country was the most Dutch of all the territories. Indeed, Suriname was the only colony with a proportionally large number of the population speaking Dutch at the time, partly due to the beginning of an educational policy in the late-nineteenth century. From the Dutch perspective, however, Suriname was, metaphorically speaking, at a much greater distance than Indonesia: the colony being unimportant both economically and geopolitically, the number of Dutch people living there small, as well as the number of Surinamese people visiting the Netherlands.

In general, the cultural connection with the Antillean islands was even weaker. Although, as with Suriname, the islands had few indigenous communities, the Dutch language was never adopted by any island, except in the sphere of administration and education. The Papiamentu-speaking Leeward Islands were traditionally focused on their Spanish-American surroundings, the Windward Antilles on their own English-speaking region. In both cases the 'mother country' was very far away. The arrival of Shell on Curaçao went only a limited way in bridging the gap between the two communities.

The consequences of this divide will become clear. At the onset of the decolonisation process, the Netherlands was mainly guided by the desire to keep Indonesia within the Kingdom. Suriname and the Antilles, small and problematic possessions very far away both geographically and culturally, were completely overshadowed by the Dutch-East Indies relationship. Furthermore, the inherent diversity within the Dutch Caribbean was seldom acknowledged by The Hague. 
Against this background the results of the Dutch decolonisation process are remarkable. Indonesia, much to Dutch chagrin, fought itself out of the Kingdom. Suriname, reputedly the colony most akin to the metropolis, opted out. Today only the Caribbean islands remain firmly linked with the Netherlands, despite a long history of mutual disregard and antagonism. Consequently, the Kingdom of the Netherlands now consists of three countries: the Netherlands with over sixteen million inhabitants, the Netherlands Antilles with around 175,000 and Aruba with over 90,000. Asymmetrical bonds these are, indeed. In the meantime, we find some 325,00o Dutch of Surinamese origin and 125,00o Antilleans and Arubans in the metropolis, a growing diaspora which has produced truly transnational Dutch Caribbean communities. 


\section{The Dismantling of the Dutch Empire, 1940-1954}

World War II signified a definitive breach in Dutch colonial history. A virtually powerless government in exile stood before the almost impossible task of not only monitoring the developments in the occupied Netherlands from London, but also using what little influence that remained to give them some form of guidance. These circumstances also impeded the overseas affairs. The Japanese occupation of Indonesia in 1942 was a second heavy blow. Only in Suriname and the Netherlands Antilles did Dutch rule continue. The Ministry of Colonial Affairs was now sending its directives from London to Paramaribo and Willemstad. In actual practice, however, the West Indian territories were dependent on the protection of the Allied forces, especially of the United States. On all counts, therefore, the Dutch colonial position was precarious.

During the war, and in the first few years following, colonial affairs would become of major concern for successive Dutch cabinets, with most attention focused on Indonesia. The war left the Netherlands impoverished and insecure regarding its prospects. In the first post-war years, hundreds of thousands of Dutch citizens emigrated to seemingly more promising countries such as the United States, Canada, Australia and New Zealand. The emerging Cold War only increased insecurity, but the effects of the Marshall assistance would induce the miraculous economic growth of the 1950 and 1960 s. Politically, moderation was the key. From 1945 up to 1958 , broad and moderate centre-left alliances governed the country, with a strongly pro-Atlantic and anti-communist stance. Decolonisation policies were usually backed by large majorities in parliament. Anti-colonial protests mainly emanated from the rather small Communist Party, while the occasional public demonstrations relating to colonial issues were actually aimed at a toughening of the Dutch stance towards the Indonesian republicans.

Only following the independence of Indonesia in 1949, leaving New Guinea as the sole remaining territory in the East Indies, the Dutch began to focus their attention on the Caribbean, through necessity, but not without a willingness to make a fresh start. Public interest in this issue was nil. Never again would the colonies hold the same significance for the Netherlands as they had in the times of the East Indies; at the same time, the Dutch government would become more directly involved with Suriname and the Antilles than ever before.

In the closing days of the war, Dutch government broke with the notion 
of 'colonies'. This was a largely symbolic gesture which had already become law in the constitutional amendment of 1922, but in practice had not yet come into effect. In 1945 the colonies were renamed 'overseas territories'. By then of course, on 17 August 1945, the Indonesian nationalist movement under Sukarno had already declared its independence. The Caribbean colonies did continue under the new flag of 'overseas territories', only to become equal and autonomous partners within the Kingdom of the Netherlands nine years later. During those nine years, in a process of intensive and relatively open transatlantic deliberations - a novelty in this colonial history - the transition was made from colonial to post-colonial relations. In 1954 the new relationship was laid down in the Statuut or 'Charter of the Kingdom of the Netherlands', which in an almost unamended form continues to exist into the twenty-first century.

By then, in Suriname and the Netherlands Antilles, the system of parliamentary democracy with universal suffrage had also become effective. In this way, not only did the former colonies become equal partners - if only in a formal sense - but they also adopted a Dutch style of administration. Paradoxically, the democratisation process and the Charter would offer Suriname and the islands the possibility to follow their own path and reject, in principle at least, a further assimilation with the Netherlands. However, this chapter would be written only after 1954 .

\section{World War II, Powerless Dutch Colonialism and the Atlantic Charter}

On 10 May 1940 the German army invaded the Netherlands. Five days later the country surrendered and the Queen fled to Great Britain, together with her ministers. During the war Queen Wilhelmina would address her people on countless occasions from London. At the time, not only did her people include the inhabitants of the occupied home country, but also the citizens who were still 'at liberty' - a rather disputable concept of course, under colonialism - in the overseas territories: the Dutch East Indies, Suriname and the Antilles.

In London, the Dutch war cabinet under Prime Minister P.S. Gerbrandy carried on its regime where possible. However, only the Ministries of Colonial Affairs and Foreign Affairs could actually implement whatever was developed as policy from the London exile. Indonesia remained the government's primary 'colonial' concern, even after its capitulation to Japan, on 9 March 1942. West Indian affairs occupied very little of the Ministry of Colonial Affairs' time. Apart from war related events, the cabinet's most important issue was how to shape the post-war Kingdom, which they hoped would include Indonesia. This was far from easy, not only because of the Japanese occupation, but also because of the - for the Dutch - unexpected 
and widespread rise of Indonesian nationalism and the growing American pressure to take the nationalist wishes seriously. The Dutch cabinet began to accept long before the Queen that after the ending of the war it would be impossible to continue the colonial relations in the same manner as before. According to the catholic Minister of Colonial Affairs Ch.J.I.M. Welter, the Dutch government had to make concessions; he was even hoping for a status of future 'federative autonomy' in the East Indies. Most of his colleagues were sceptical about his plans and warned against too much publicity which would possibly 'create illusions' overseas. Others wondered whether a change in the structure of the Kingdom was even necessary at all. There were never talks of any radical plans, which is clearly visible in a secret memorandum dated August 1940, in which Welter restated that for the East Indies there was no reasonable political alternative to the present one, which was characterised as 'A gradual process of becoming autonomous under the gentle tutelage of a highly developed, trading and unarmed people such as the Dutch'. The Caribbean colonies were not specifically mentioned, either in the memorandum or in the Council of Ministers. ${ }^{1}$

It would take almost another year, until April 1941, before the cabinet approved the proposal of Welter to announce a public conference on the future relations within the Kingdom. Despite initial objections by Queen Wilhelmina, who considered 'the promise to convene an imperial commission irresponsible, this line of policy was carried through. ${ }^{2}$ In a radio speech in May 1941 the Queen announced that political changes after the war would also be applicable to the colonies. She did not yet mention a public conference. One month later, the Governor-General in the East Indies did, as did the cabinet in London and the Governors of Suriname and the Antilles. The postponement of the conference until after the war was received with disappointment in the East. Clearly, from the Dutch perspective, reticence and prudence remained the motto.

Meanwhile, in August 1941, Roosevelt along with Churchill - who was somewhat dragging his feet - in their Atlantic Charter had equated the Allied battle against Nazi-Germany with a war against any form of oppression, and had propagated the right of any people, wherever in the world, to choose in freedom their own form of government. A new approach to colonialism had been confirmed and was, in fact, also imposed. The Dutch government was not enthusiastic. Prime Minister Gerbrandy initially considered the Charter to be a 'feeble piece' of little relevance to the Netherlands. ${ }^{3}$ Yet a frank refusal to subscribe to these principles would not only have damaged the Dutch credibility, but could also have endangered the Allied readiness to accord assistance to the protection of the Dutch colonies.

In this light, during the course of 1942 , the Council of Ministers regularly discussed the prospect of a public conference, the attention still mainly focused on Indonesia. As by this time the colony had been lost to Dutch authority, such talks were even more speculative: before any new relations 
could be realised, not only did the Netherlands, but also the East Indies need to be liberated. Besides, all along Queen Wilhelmina remained more conservative than the cabinet. Whereas the new, relatively progressive Minister of Colonial Affairs H.J. van Mook believed that any post-war developments should be openly discussed, especially the agenda of the colonial conference - 'The liberation should not be seen as a screen beyond which there is little interest or inspiration' - the Queen continued to express herself in rather vague terms, even in her speech to the American Congress in August 1942, despite direct pressure from Roosevelt to do otherwise. ${ }^{4}$ Even if the Dutch head of state was still thinking in terms of 'enlightened extrapolation' of the post-war colonial relations, in the meantime increasing international pressure, guided by the United States, urged for more drastic measures of decolonisation.

In October 1942, van Mook presented the Council of Ministers with a proposal on the future relations within the Kingdom. The proposal bore the title 'Constitutional reform in the Netherlands and the Dutch East Indies' - a telling illustration of the peripheral position of the Caribbean colonies. ${ }^{5}$ Van Mook, born and raised in Indonesia and already a moderate reformer before the war, by now was firmly convinced of the need for political reforms, not only in view of the wishes in the colonies, but also those of the Allies. In this way he also hoped to offset the 'rooting of the enemy'. Even though in his view the unity of the Kingdom could and should be preserved, van Mook imagined that the newly constituted countries should form equal parts, taking care of their 'internal affairs' themselves. This principle was acceptable to the cabinet by then. However, his proposals for a 'Ministry of Kingdom Affairs' and a 'Parliament for the Kingdom' were not accepted. Furthermore, the Council of Ministers was generally of the opinion that Suriname and the Antilles were too insignificant to occupy an equal position next to the Netherlands and Indonesia. The plans also met with objections from the Queen, who thought it would be bad policy to 'map' the Kingdom while the war was still raging; she argued that this would undermine the elementary rights of the occupied countries and therefore silenced citizens of the Netherlands and the East Indies - one assumes she was merely thinking of the European and local elites in these countries. Again, the Caribbean colonies did not play a noticeable part in the considerations. ${ }^{6}$

On 6 December 1942 Wilhelmina, who had up until then sought to have her objections prevail against any far-reaching concessions, relented to Allied and cabinet pressure and gave a long awaited radio speech on the future relationships within the Kingdom. This speech gave evidence of the understanding that after the war the Dutch government would have to follow a new avenue. The Queen spoke of 'full partnership' and 'internal autonomy' for the overseas territories, and of a new future in which shared solidarity rather than an imposed Dutch authority would shape the rela- 
tions. However, there was no straight talk about the right to independence. The Queen only expressed the conviction 'that no political unity nor national cohesion can continue to exist if they are not supported by the voluntary acceptance and the faith of the great majority of the citizenry."

The reactions in the American and British press were for the most part positive. Headlines in the American newspapers left little room for conservative interpretations: 'Dutch commonwealth policy embracing internal independence and external collaboration.' In Curaçao and Suriname people were said to be, at least according to Dutch sources, 'delighted and approving. The announcement of a post-war colonial conference, to which West Indian representatives were also going to be invited, was welcomed as a demonstration of the growing awareness of their importance. In fact, the war had boosted the Caribbean economies: the oil refineries on Curaçao and Aruba produced an important part of the fuel needed by the Allies, and the Surinamese bauxite was a primary factor in the American war industry. In this way, the Caribbean territories were instrumental in Allied warfare and hence contributed directly to the liberation of the Netherlands. Without doubt, these developments were conducive to the growth of an optimistic self-confidence among the Caribbean elites.

It was now the task of the war cabinet in London to prepare for the implementation of promises made. During the war this only led to one institutional change which, if not practical, in a symbolic sense showed a willingness to reform the colonial relationships. In February 1945 the Ministry of Colonial Affairs was renamed 'Ministry of the Overseas Territories'. In official declarations the Dutch government continued to speak in glowing terms about the 'awakened realisation that the Kingdom is made up of its four component parts, big and small, and that those parts need to know, understand and appreciate each other, and yes, love one another, in order to be stronger after the reunion than ever before. ${ }^{8}$ Seen from Paramaribo or Willemstad, these few declarations from London may have been encouraging, but were also rather vague, and therefore disappointing. It seemed as though nothing progressed beyond the planning stage. The political discussions that followed the Queen's radio speech of December 1942 show clearly that - in as far as concrete reforms were discussed in the cabinet the concerns were mainly related to Indonesia. It was not until after the liberation in May 1945, that the position of Suriname and the Antilles within the Kingdom would re-emerge as a topic for consideration. During the war Dutch policymakers gave no serious consideration to any objections raised against their colonial administrations, and in particular against the authoritarian rule by the respective Governors in the Caribbean territories. The first-ever visits of the ministers of Colonial Affairs to Curaçao and Suriname had made no difference in this respect.

The royal speech of 6 December 1942 has gone down in history as a milestone in the Dutch decolonisation policy. However, the 'December speech' 
came too late to be able to play a key role for Indonesia; in this respect the speech ended an era as opposed to being the start of a new one. On the other hand, for Suriname and the Antilles the same speech did mark a new beginning of their history shared with the Netherlands. Its spirit and objectives, articulated with the hopes of keeping Indonesia within the Kingdom, would be confirmed in the 1954 Charter of the Kingdom, granting the Caribbean colonies 'autonomy in internal affairs' and thereby the status of autonomous partners within the Kingdom.

\section{In the Shadow of Indonesia}

The end of World War II cleared the way for the realisation of the promises made during the war. The local elites in Suriname and the Netherlands Antilles had high expectations. In the Netherlands, however, the reconstruction of the devastated homeland took priority. Next, the consideration of colonial relations mainly concerned Indonesia, which in 1945 had unilaterally declared itself independent.

A brief discussion of Dutch decolonisation policies in the Dutch East Indies is appropriate at this point, not simply to paint a broader picture, but also to provide a deeper insight into the fundamentals of Dutch thinking on the colonies and their own task there. ${ }^{9}$ Some permanent features of post-war Dutch policies towards decolonisation and international development aid have settled in the national self-image as typically Dutch. These include an almost missionary fervour towards the overseas territories, later sublimated in relatively generous spending on development aid. Coupled with this is a degree of paternalistic interference in local politics, often perceived as straightforward post-colonialism in the relevant sovereign countries. Yet at the same time, The Hague's policy towards Indonesian nationalism testifies to a conservative approach and even a willingness to resort to brutal oppression, the reality of which has been pretty well suppressed in the Dutch psyche.

Both in the pre-war years and during World War II, all leading Dutch politicians, whether in the metropolis or in the colony, considered the East Indies to be a crucial extension of the Kingdom. The Indonesian contribution to the Dutch economy was significant, and indeed many leading figures thought of this colonial contribution as 'the cork which keeps the Dutch economy from sinking'. Moreover, there was the geopolitical argument that with its immense Asian extension the Kingdom counted as a world power. As it was envisaged, even in the Dutch parliament, without Indonesia the Netherlands would degrade 'to the rank of a country such as Denmark'. Coupled with such observations was the paternalistic conviction, again shared by virtually all involved Dutch parties, that without their colonial presence the East Indies were destined for disintegration and 
collapse. Prolonged Dutch presence should therefore be regarded by the Indonesians as a favour, as opposed to an imposition. Tangible self-interest was thus happily married to an ethical mission.

Preparations for a gradual and ultimately only partial transfer of power were discussed in the inter-war years. Within Dutch colonial circles, prominent civil servants and intellectuals of social democratic leanings centred around the journal De Stuw and pleaded for reform. Leading post-war politicians such as the successive Ministers van Mook, Logemann and Jonkman figured prominently in this debate. Yet little was achieved; Dutch - like French - colonial rule proved to be far more reactionary than the policies enacted by the British and the Americans. By the time the Japanese conquered the Netherlands East Indies, the colony had achieved no local autonomy, neither did it have the prospect of a transition to independence. To make matters worse, due to the overbearing nature of Dutch colonial rule, the involvement of Indonesians in the middle and higher echelons of education and administration was extremely low, particularly in comparison to British India and the Philippines. Among the Indonesian elites, growing resentment manifested itself in a more vociferous nationalist movement, headed, among others, by Sukarno. The Dutch paid little attention to these explicit warnings and continued to act in a repressive manner, imprisoning Sukarno and other nationalist leaders for long periods of time. Meanwhile, the Dutch continued to assure one another that the nationalist movement was anything but representative of the mood of the people, who were supposedly content to continue under benign colonial rule.

As the Dutch war cabinet considered its future colonial policies, it had to face the challenge of a fundamental reappraisal. Yet the very convictions which had stopped The Hague from introducing major reforms in the prewar period had not changed. The loss of Indonesia was perceived as a nightmare because of its crucial economic and geopolitical interest; it was also widely believed by the Dutch that their presence was crucial to Indonesia's stability. The alarming fact that there had been hardly any Indonesian support for the Dutch against the Japanese was disregarded, and the initial nationalist siding with the new occupying force was simply depicted as criminal collaboration. After the war, a new start had to be made, with more local autonomy and representation - but not without Dutch supervision. Even if the time for a transfer of power might one day come, this would be a distant goal. In the meantime, so the Dutch thought, they were as indispensable to the Indonesians as the colony was to the metropolis.

After the military defeat of the Japanese, and despite the immediate proclamation of independence by Sukarno on 17 August 1945, the Dutch hoped for a preliminary restoration of their military and administrative power as a prerequisite for subsequent reform. In October 1945, Minister of Overseas Territories J.H.A. Logemann ruled out direct negotiations with 
Sukarno. In fact, as he stated to an enthusiastic parliament, his country 'feels the intrinsic power to continue its historical mission, to restore order, safety and prosperity, to let the East Indies experience the blessing of being part of the Kingdom of the Netherlands'. Although Logemann would later shift to a more pragmatic stance, his ideological point of departure stayed faithful to the general Dutch attitude in the immediate post-war period. ${ }^{10}$ Naturally, such blatant paternalism was often supported by openly racist underpinnings. Any form of political wavering was routinely dismissed by the colonial lobby and military leadership as, in the words of commander of staff Spoor, being inspired by 'a lack of any moral virtue and dignity whatsoever'. ${ }^{11}$

In the end, four years elapsed between the 17 August 1945 nationalist proclamation of independence and the official transfer of sovereignty by the Dutch to the Indonesian government, on 27 November 1949. As the process unfolded, Dutch authorities in Indonesia itself, headed by the former Minister of Colonial Affairs, now Governor van Mook, were confronted by the extremely rigid policies of their home government, which bluntly prided itself in 'living with principles rather than under the impact of facts. ${ }^{12}$ Eventually, however, despite or perhaps even in line with his prewar reformist and paternalistic inclinations, van Mook would also lose faith in a negotiated peace with the republicans. In protracted negotiations, via the attempt to at least restrict future republican rule to Java and Sumatra - thus excluding major outer parts of the Indonesian archipelago from the Republic - the Dutch position moved from an absolute refusal to deal with its republican opponents to agreeing to the transfer of sovereignty to a federal state in which the republicans would not be hegemonic. By then, The Hague had also opted for a future 'Union' between the Kingdom of the Netherlands - including Suriname and the Antilles - and the federal Indonesian state.

This policy failed badly and on two occasions the Dutch opted for military intervention, in the summer of 1947 and late in 1948. Again, responsibility rather than interest provided justification. As the social democratic Prime Minister, Willem Drees, stated, war was inevitable 'unless one would opt for leaving the Indonesian people to fend for themselves, initially anarchy would be the consequence and subsequently dictatorship'. And so the Dutch opted for military force, euphemistically called 'police actions' but in fact, the U.s. State Department, among others, had already concluded even before the act that this was nothing short of 'a new colonial war'. ${ }^{13}$

The two military interventions achieved mixed results; the political impact was disastrous. With the exception of the Communist Party, all Dutch political parties supported their government in its abhorrence of the 'collaborating' republicans and in its decision to resort to warfare. Yet international opinion would disagree. As The Hague continued to make fatal miscalculations both regarding the strength of Indonesian republicanism and 
its own growing international isolation, the emerging Cold War set new parameters. Eventually, the United States chose to support Sukarno precisely because he was considered a crucial asset in the struggle to hold communism at bay in the archipelago. What little sympathy there had been for Dutch policy consequently evaporated.

By early 1948 The Hague was isolated within its former Allied habitat to the point that the Americans actually threatened to withhold the badly needed Marshall Aid programme. Grudgingly the Dutch cabinet consented, and transferred sovereignty to the Republic, governed by the still abhorred Sukarno. Only New Guinea was excluded from the treaty; it was not until 1961 that the Dutch relinquished this last part of the former East Indies, again under strong pressure from the United States and the United Nations. In 1962 New Guinea was fully incorporated into the Republic of Indonesia. Not surprisingly, the Dutch ideal of a bilateral Union never fully materialised. Initially conceived of as a strong political union under the Dutch Crown, its objectives were soon scaled down to merely a vehicle for economic and cultural cooperation. But the Union would fail to function even in this limited way - Sukarno would have the last word by unilaterally cancelling the Union in 1956.

The Dutch failure to accomplish a peaceful decolonisation had resulted in some 5,000 Dutch and 150,000 Indonesian casualties. Unsurprisingly, Dutch-Indonesian relations were to remain strained for decades to come. Furthermore, post-colonial relations were burdened by Indonesian apprehensions of continued Dutch paternalism in the fields of development aid and, at a later stage, debates on human rights in the Suharto period. Meanwhile, it took the Dutch government and parliament several decades to develop a critical reappraisal of this period. This reassessment is anything but concluded. In fact, heated debates at the time of the 1995 visit of the Dutch Queen Beatrix to Indonesia centred on the question as to whether she should apologise for the last colonial war; in the end, she did not. In spite of this, one can confidently state that in the last decades, the general understanding in Dutch politics and intellectual circles has been that the 19451949 colonial policy represents a nadir in the country's post-war history.

For Dutch decolonisation policies in the Caribbean this sad history would have several consequences. From the Caribbean, the Dutch approach to Indonesia was naturally viewed with growing suspicion. This apprehension, however, proved fairly inconsequential as neither the Antilleans nor the Surinamese dared or cared to openly speak out against Dutch policy. In the period up to 1949, the slow negotiations - eventually resulting in the 1954 Charter - suffered from an absence of any sense of urgency on the Dutch side. In the following years, however, it was the poor image which The Hague had gained through its handling of the Indonesian decolonisation which would provide its Caribbean partners with a trump card in the negotiations. After all, the Dutch badly needed a redemptive success, a sec- 
ond chance in decolonisation which would improve their international image. Hence, one may conclude, the Dutch willingness to grant significant concessions in the Charter and thus, two decades later, the Dutch attempt to redeem the moral cataclysm in Indonesia with a 'model decolonisation' in the Caribbean.

Yet let us first return to 1945. With the restoration of Dutch sovereignty, decision making once more took place largely in The Hague. The post-war environment required a new attitude from politicians, administrators and civil servants, which was to be reflected in their policy making. This was no easy feat, as had become evident as a result of the turbulent decolonisation of Indonesia. In the margins of their prime colonial concern, Dutch politicians now also needed to take their Surinamese and Antillean counterparts seriously. This demanded a mentality change on the part of the Dutch policy makers with their long tradition of derogatory remarks and condescending behaviour. They faced the challenge of dealing on an equal footing with the leaders of countries that, within the foreseeable future, would occupy an autonomous place within the Kingdom. This was not accomplished in the short term and it is questionable if it will ever be accomplished. For example, no consideration was given to questions such as the appointment of a native Surinamese or Antillean Governor. The Hague stuck to a policy of pulling the strings.

From a Caribbean perspective, the recent history of their Dutch counterparts could only elicit doubts as to their true interests and intentions. Of the six ministers of Colonial Affairs or, since 1945, Overseas Territories, acting between Queen Wilhelmina's December 1942 speech and the transfer of sovereignty to Indonesia in 1949, none were acquainted with the Caribbean colonies. Three - van Mook, Logemann and Jonkman - were profoundly at home in Indonesia, where before the war they had been counted among the progressive reformists. In practice, this would not keep them from helping to shape the reactionary Dutch decolonisation policy for Indonesia. The social democrat J.A. Jonkman, for example, as late as 1946 argued that the Dutch had 'a right to an overseas calling. That is why we need an empire.'14 Of the four ministers handling Caribbean affairs between 1949 and 1954, only one had been involved in the decolonisation of Indonesia; again, none had any prior knowledge of the Dutch Caribbean.

The primary aim of the first post-war cabinets became the practical realisation of the December speech. Initially the West Indies were largely neglected. In declarations on future reforms within the Kingdom they were mentioned only dutifully and sometimes even literally figured in brackets. This happened in the government policy statement of February 1946 pronounced by the Minister of the Overseas Territories, Logemann, like van Mook a social democrat with an impressive administrative career in the East Indies and considered a progressive figure there in the pre-war period: 'The Dutch government is very much prepared to set itself as a clear and 
rapidly attainable goal for Indonesia's (and of course also Suriname's and Curaçao's) political development, the legitimate goal of any people as has been recognised in the Atlantic Charter and the Charter of the United Nations, namely the right to self-determination. ${ }^{15}$ Ironically, eight years later the Dutch government would frustrate the inclusion of the notion of this 'right to self-determination' in the Charter of the Kingdom. This political principle, at the time mentioned exclusively in view of Indonesia, and still with little meaning for Suriname and the Antilles, had by then become a crucial element in the decision making process with respect to the West Indies. $^{16}$

Returning to the 1945 Dutch Caribbean, none of the three parties involved even considered independence. For the Surinamese and Antillean elites, autonomy was the ultimate goal. Even if there was no great interest in these minor colonies, the Dutch certainly did not consider leaving the region altogether. Economic interest is no credible explanation here. There was a feeling that a mission needed to be accomplished. Perhaps The Hague longed to hold on to a certain prestige in world politics as well, although this is difficult to ascertain. In fact, only during the war did the Dutch reveal their own longing to retain West Indian territory. As the Allied forces decided on a pre-emptive occupation of both Suriname and the Antilles to secure the vital bauxite industry and oil refineries, the government exiled in London could only consent. Yet what little initial opposition it did voice was primarily inspired by its apprehension that Brazil and Venezuela would join the operation and then decide never to vacate the colonies. U.s. President Roosevelt wryly characterised the Dutch concerns on this issue as 'perfectly childish. ${ }^{17}$

In the end, following the war both colonies were fully restored to the Netherlands. Looking back on the genesis of the Charter, one cannot but conclude that there was no sense of urgency within either of the parties regarding possible Latin American incursions in the process. Still, the apprehension was never fully forgotten that these two Latin countries - particularly Venezuela, which indeed occasionally formulated claims in international arenas such as the 1948 pan-American conference in Bogotá would one day claim these relics from colonial times in armed struggle. Characteristically, such apprehensions ultimately became a trump card played by the Antilles to keep the Dutch from moving out entirely. ${ }^{18}$

Local and bilateral issues dominated the 1945 agenda. In preparation for the announced conference regarding the structure of the Kingdom, Logemann had installed commissions in the Netherlands, Suriname and $\mathrm{Cu}-$ raçao with the task of gauging the opinions and wishes of the local populations with respect to possible reforms. In general the questionnaires got very little response. It became mainly clear that amongst the people there was only a fairly vague desire to become more autonomous and of equal status within the Kingdom. Even though the existing bonds were charac- 
terised as out of date and purely colonial, the wish to end the relations was never voiced. In fact, it became quite clear that the transatlantic relations had not yet been given much thought at all. Far more attention was paid to grievances surrounding the local administrations - the powerless local councils, the limited right to vote, the dominating Governor - than to the relationship with the 'home country'. There was a general feeling that economic dependence could easily block the path to autonomy.

Together, the reports of these three commissions were intended to be preliminary work for the announced conference, but the dramatic developments in Indonesia thwarted this. The slow course of events - it would take another year and a half before the conference would actually take place fuelled the resentment in Suriname and the Antilles that The Hague was not standing by the promises made during the war. This growing impatience drove the Curaçaoan Staten [proto-parliament] members to visit their Surinamese counterparts in April 1946 which, two months later, resulted in the presentation of petitions to the Queen. According to the petitions, in the future, each country within the Kingdom was to take care of its own internal affairs. To this end the administrative leeway under the existing state regulations - dating from 1936 - needed to be expanded upon. The Surinamese delegation was the boldest, her aim being the obtainment 'in the shortest term, of the right to self-determination. ${ }^{19}$ After six months this key notion from the speech of Minister Logemann was being used as a political weapon.

The discussions in The Hague were completed to the satisfaction of all parties. Back in Willemstad the Antillean delegation declared 'we have returned with autonomy', and assured that all political wishes would be translated into law. In Paramaribo the delegation announced that the talks 'will contribute to the strengthening of bonds between Suriname and the Netherlands'. ${ }^{20}$ The Dutch reactions were equally positive. In fact this outcome had not been difficult to achieve; not only had the overseas representatives continuously emphasised their adherence to the Kingdom and the House of Orange, the talks had also been limited to possible reforms under the existing Constitution, all of which had been agreed to even before the talks began.

In all official declarations of 1946 this conciliatory tone was maintained; political innovations which would involve no constitutional amendments would be settled as soon as possible. It was decided that political reforms concerning the future structure of the Kingdom at large would be distinguished from those aimed at the broadening of local autonomy. The Dutch showed a willingness to immediately discuss more autonomy, implying, however, the postponement of the conference on the structure of the Kingdom.

One tangible result of the petitions in The Hague was the inclusion of a Surinamese and an Antillean representative into the Dutch Council of Min- 
isters. This intention only became effective in March 1947, when an Antillean representative was appointed, whereas his Surinamese counterpart followed only in October 1947. Both overseas officials took part in deliberations of the Council of Ministers which were of communal interest, thus anticipating the 1954 establishment of a Kingdom cabinet.

Despite all promises and good intentions, between the summers of 1946 and 1947 no substantial progress in the decolonisation process was made. The Dutch government concerned itself with domestic matters and problems relating to Indonesia. 'Impatience is growing rapidly and with it the distrust of the Dutch government', was the characterisation of the atmosphere in Curaçao and Suriname. ${ }^{21}$

A Dutch parliamentary visit to the West Indies in January 1947 restored hopes for quick reforms. From all sides the delegation was notified that it was now necessary to come forward with rapid proposals for new state regulations. These wishes did not fall on deaf ears; in June 1947 the relevant bills were introduced for consultation in the Staten of Suriname and Curaçao. The reactions were mixed; although the Antillean Staten members welcomed the bill, they believed that The Hague had taken insufficient notice of their wishes as expressed in the petition one year earlier. In Suriname, remarkably, there was criticism of the proposed broadening of voting rights - the Creole elite in the Staten had major reservations, fearing an 'Asiatic' domination. A general complaint was the slowness of the reforms and the feeling that the Dutch government was applying double standards: Indonesia had been offered a high degree of independence, with the help of extraordinary laws and the bypassing of the Constitution, none of which applied to Suriname and the Antilles. J.C. Brons, Governor of Suriname, made mention of 'bitterness', while from the Antilles came the message that 'there is no more interest in talking, we want to see some action from the Dutch government'. ${ }^{22}$

The proposals for legislation enhancing Caribbean autonomy were presented to Dutch parliament at the end of 1947 and became law in May 1948 - almost two years after the petitions relating to this goal had been presented to the Queen. In the meantime, in August 1947, the government had announced its intention to discuss the structure of a new Kingdom in a 'preliminary conference' in the second half of September - the talks would not include Indonesia, as the decolonisation in Asia by then had acquired a momentum of its own.

\section{The Round-Table Conferences}

The 'round-table conference' finally started - with the now almost traditional delay - in January 1948. In open discussions the conference was supposed to lay the foundations for a new constitutional order within the 
Kingdom. With this initiative the Netherlands was hoping not only to meet the wishes of the Surinamese and Antillean delegates, but also to improve its image internationally, which due to the hardline stance it had taken in Indonesia was now considered old-fashioned and colonial.

However, the failure of this first conference was brewing right from the start. The Antillean delegation came to The Hague with requests that were considered too far-reaching, namely the immediate recognition of full equality of the Antilles to the Netherlands, and the separation of Aruba from the other islands in order to become a country in its own right within the Kingdom. The flat Dutch refusal to accept these propositions caused several Antillean delegates to leave the conference prematurely. And there were further problems. The Dutch Council of Ministers expressed serious objections to the suggestions of Jonkman, the new Minister of the Overseas Territories, for the establishment of a 'Cabinet of the Kingdom' and other Kingdom institutions. The social democratic Prime Minister Drees was of the opinion that the structure needed to become 'not top-heavy, but simple'. The only element generally agreed upon was the addition of overseas representatives to the House of Commons whenever the so-called 'affairs of the Kingdom' were being discussed. ${ }^{23}$

Frictions led the round-table conference to be adjourned in the middle of March 1948 - however not without conclusions and a further agenda. A tripartite commission was given the task of producing a Constitution for a federally constructed 'United Kingdom', which was to be founded upon the principles of 'freedom, equality and solidarity'. The intention was to discuss this draft Constitution one year later in a second plenary conference. However, this federal Constitution would not become a reality. The preliminary sketch had resulted in the (new) Dutch cabinet deciding to hush up the entire project. As Drees dryly commented: 'Instead of granting self-rule to Suriname and the Antilles, a new construction has been designed for the Kingdom which will be towering high above the Dutch one.' ${ }^{24}$ From the Dutch perspective it was inconceivable that the overseas territories would be able to get involved in matters that were considered exclusively Dutch this being one of the elements in the preliminary sketch.

The cabinet decided not to postpone the one central element within the plans which it was able to agree upon: the realisation of full autonomy for Suriname and the Antilles. To this end it was prepared to design an interim regulation' that, as it was hoped, would make the decision over a 'Kingdom Constitution' less urgent. Not only was this hope nourished by the coming into effect of a new Dutch Constitution, which allowed far-reaching changes that had been impossible at the time of the state regulations of May 1948, but the decision to focus on interim regulations instead of on a Constitution for the entire Kingdom was also rooted in Dutch insecurity surrounding the possible elaboration of a 'Union' with the intended 'United States of Indonesia'. Definitive solutions were clearly not yet within reach. 
In November 1948 the Council of Ministers agreed to the rough draft of an interim regulation as, in the words of the responsible minister, 'the preliminary sketch of the Kingdom Constitution will disappear into a drawer'. ${ }^{25}$ It would take another full year before the interim regulation would finally come into effect in Suriname (December 1949), and even longer before being fully applicable on the Antillean islands - not before February 1951. The Surinamese Staten members had characterised the first draft as 'bearing the marks of insecurity, reservation and clumsiness' and had requested - largely in vain - a say in the affairs of the Kingdom, and the appointment of three representatives advising the Dutch parliament. Their Antillean counterparts had been disappointed as well: they had found that the draft was 'not the product of mutual consultations', as it left the real decision making in the hands of the Dutch parliament. This was at odds with the 'notion of equality'. ${ }^{26}$

The Dutch on the other hand had become weary of concessions. The ensuing frictions, in combination with the imminent transfer of sovereignty to Indonesia, led to an interlude in which all parties were thinking of forgetting about an 'interim period' for the West Indies and focusing on the definitive legal order of the Kingdom instead. Dutch advisors, however, warned The Hague against the skipping of the intermediate phase, stating that: 'In Indonesian politics we were forced to work in a very improvised manner and to make opportunistic decisions on a day to day basis, leaving a more in depth reflection on structure and form mostly absent. If in this mentality the tripartite Kingdom is to be constructed, I fear that this will bring about events which in hindsight we will deeply regret.' ${ }^{\text {'7 }}$ The government took this to heart and did not let the realisation of the new political order for Suriname and the Antilles depend on the solution of its problems with Indonesia - the preparation of the interim regulations was therefore quickly resumed and finalised.

In Paramaribo the interim regulation was greeted as a decisive step towards full self-government. In the Antilles there was further delay. Interisland tension between Curaçao and Aruba deepened over the distribution of seats in the Staten - Aruba had requested the same number of representatives as the more populated island of Curaçao. In the end this dispute was half-heartedly settled, with Curaçao pushing its point and remaining the centre of gravity in the six-island state. On Curaçao the outcome was greeted as an important step towards full autonomy. Aruba, on the other hand, was dissatisfied with its 'subordination' to Curaçao, and considered the outcome a defeat, giving only a 'shadow of autonomy'. Generally, Dutch parliament was of the opinion that with this 'first, major step on the path towards close commitment, on the basis of equality within the new Kingdom' the colonial relations had come to an end. ${ }^{28}$

On 27 November 1949, the transfer of sovereignty to Indonesia took place, leaving only the Dutch hopes for a 'Union' and the fate of New 
Guinea unsettled. Shortly afterwards the interim regulation came into effect in Suriname, and was being prepared for the Antilles. Still, in the Caribbean there was a strong wish to resume the suspended round-table conference of 1948 as soon as possible, so that at least this phase of the decolonisation process could be completed. The Hague too believed that any further delay would 'fall short of the legitimate expectations', although a little more practical experience with the interim regulations 'could undoubtedly be conducive to a good definitive arrangement'. ${ }^{29}$

Progress seemed assured. In February 1950 the cabinet had already discussed - together with the two Surinamese and Antillean representatives the first version of a 'Sketch for a Charter regulating the status of the Netherlands, Suriname and the Netherlands Antilles within the Kingdom'. Initially its simplicity was favourably received; in the Antilles the preliminary draft of the Kingdom Constitution had been considered as 'very topheavy', as both overseas countries only desired a say in those affairs of the Kingdom which were affecting them directly. However, in a later stage the Surinamese government had pointed at the contradiction between the principle of equality and the proposed high measure of overlap between the Kingdom and the Netherlands - implying that the Dutch Constitution would de facto also become the Constitution of the tripartite Kingdom. Soon, the Antilles also began to voice similar objections against the prospective Charter. The Dutch cabinet felt compelled to withdraw its plans.

All preparations for a new Kingdom order now lay dormant. Only in July 1951 was it decided that a small governmental commission would make a new proposal as the basis for a final round-table conference, intended to take place in March 1952. This time the Governors of Suriname and the Antilles were having doubts. Governor A.A.M. Struycken of the Antilles was of the opinion that with the interim regulation the Dutch government had already transferred too much autonomy, especially with respect to the authority of the Governor. Governor of Suriname, Klaasesz, had already made attempts at temporarily pushing the Staten aside in order to put all decision making power back into his own hands. The Dutch government listened to these rather reactionary voices, but paid little heed to them.

At the end of 1951 the preparatory commission for the round-table conference held meetings in Willemstad and Paramaribo, resulting in the draft proposal for the Charter, within which the range of the affairs of the Kingdom had been more narrowly defined than in the earlier version of the Sketch. Existing Dutch governmental institutions were now redefined as 'Kingdom institutions'; Suriname and the Antilles abandoned the idea of electing their own representatives to the Dutch parliament. The Dutch Council of Ministers was positive about this draft proposal. Van Schaik, the new Minister concerned, had stated that 'apart from psychological considerations, Suriname and the Antilles only have an interest in a strengthened 
position within the Kingdom, to which they already belong from time immemorial, a position which will assure them influence in certain affairs of the Kingdom. ${ }^{30}$

Again the preparations were thwarted, this time by a strongly diverging Surinamese memorandum, in which a federal structure of three almost independent countries was put forward. Its language was clear: 'Suriname is not prepared to accept any regulation which leaves the decision making in the hands of the Netherlands.' Governor Struycken interpreted this more as an attempt to create an advantageous negotiating position in order to procure further concessions from The Hague: 'All of this may seem unreal in the Netherlands, but it is a tangible and clear tactic in these countries.' According to Struycken, by consciously 'over asking', Suriname was betting on the 'lenience and a misplaced sense of inevitability on the Dutch side. ${ }^{1}$ Further consultations within the preparatory commission resulted in a soothing of tensions, even though, as it would appear later, this was in no way a real solution to the potential crisis.

In January 1952 Prime Minister Drees spoke to the Council of Ministers about the importance to 'foster the psychological good mood' during the period leading up to the conference. 'Community and trust' were the key notions. Somewhat in contradiction with this statement, Peters, the Minister for Union Affairs and the Overseas Territories, warned against focusing on the international aspect, or justifying Dutch policies in the United $\mathrm{Na}-$ tions, since in this way Suriname and the Antilles would only be dealt a trump card. Other ministers believed that the economic dependence of the overseas territories needed to be emphasised, otherwise the Surinamese and Antillean politicians would 'too easily end up overestimating their own position'. The dilemma was clear: in the best possible atmosphere the Netherlands did not want to part with too much, an attitude which would only cause more tension. ${ }^{32}$

Nevertheless, in February 1952 the preparatory commission reached an agreement over a definitive text of the 'Draft proposal for a Charter of the Kingdom'. The round-table conference could commence. On 3 April 1952 Prime Minister and now chairman Drees opened the conference. He talked of recent history, the period of four years during which 'one political reform after the other has taken place'. The new round-table conference was to conclude this chapter. 'A growth process has taken place. The realisation has dawned that in our Kingdom with its completely unique composition a theoretically pure structure could be too ambiguous and then give no appropriate solution.' A sober structure was also required in order to avoid a brain drain of capable Caribbean citizens taking up governmental positions in The Hague.

An incorporation of the former colonies into the metropolitan area in the form of overseas provinces - after the example of the French Caribbean territories of Guadeloupe, Martinique and French Guiana - was out of the 
question. 'The solution is surely not to be found in the assimilation of Suriname and the Antilles as overseas provinces; that would be completely unrealistic and lead to incalculable difficulties.' The status of full autonomy had already been reached; a strong foundation for mutual help and assistance now had to be attained. According to Drees, there was a clear inclination towards this in the three countries, and a great willingness 'to make a sacrifice so that together we stand stronger in the world'. Buiskool, the chairman of the Surinamese delegation, emphasised that everything depended on 'mutual trust and the will to know and understand each other's needs and circumstances'. The chairman of the Antillean delegation, Da Costa Gomez, praised the 'practical, simple and effective' draft proposal. He too emphasised the importance of mutual trust and the willingness for cooperation, support and assistance. 'For a long time the connection has been looked for in the shared history and in legal formulations, whilst in reality that connection exists in a cultural tradition which created valuable civilian virtues, the spirit of enterprise and an unimpeachable administrative machinery which promotes legal security. ${ }^{33}$

In contrast with the round-table conference of 1948 , the consultations were now taking place between the three governments directly. This did not always make things more easy. Despite all high expectations the 'draft for a Charter' did not evoke consensus. This made further, unwelcome rounds of negotiations necessary. For the Dutch government - which had to reckon with its tainted image on the international scene - this was very unpleasant indeed.

At the end of April 1952, a still optimistic Minister Peters informed his colleagues that good progress had been made; he was hoping that the conference would be finished no later than 10 May 1952. However, two weeks later he was more prudent. An agreement had still not been reached on the formulation of the preamble of the Charter. In particular the Surinamese strove for the formal recognition of the principle of self-determination. The Dutch government saw in this the - unacceptable - risk of unilateral secession from the Kingdom and therefore objected to any reference to the right of self-determination in the Charter. Since an agreement was not within sight, at the end of May the conference was adjourned at the instigation of the Surinamese. In their view, the Dutch had shown too little understanding of the changed circumstances: 'Time and again it turned out that one still wanted to keep a very strong say in all kinds of decisions concerning the overseas countries, with which one began to lose sight of the fact that the future relations need to be based on trust in the first place. ${ }^{34}$ The Antillean delegation, having agreed with the draft proposal and the preamble, had in vain urged for a speedy conclusion to the talks.

Minister Peters believed that the Dutch delegation 'has gone as far as possible' and was therefore not prepared to make any further concessions. Despite the efforts of mediators, the Dutch and Surinamese delegations 
remained diametrically opposed. Suriname insisted on the 'equality' of the three countries being expressed in the Charter. Therefore the proposed power of the Kingdom - effectively of its European part - over a guarantee of good governance in the Caribbean countries was unacceptable; this was considered as 'interference' and a 'token of distrust'. The Dutch government on the other hand, had objected to several Surinamese proposals, such as to a new flag and name for the Kingdom (the 'Kingdom of the Netherlands, Suriname and the Netherlands Antilles'), to a new regulation for the admission and expulsion of citizens from within the Kingdom, but especially to the wish to explicitly give expression to the right of self-determination in the preamble of the Charter.

The interruption of the talks caused irritation in the Netherlands and, to a lesser degree, on the islands. The Antillean press called the Surinamese attitude foolish. But The Hague was also to blame for not having been firm enough: 'In the political poker play the Netherlands has never been strong. However, sometimes it is the only remaining tactic to come to a reasonable solution when being faced with a party with excessive demands. What in the end has the Netherlands got to lose if Suriname does not want to remain within the Kingdom?'35

In a subsequent discussion within the Council of Ministers, Prime Minister Drees cast doubt on the viewpoint that 'in the preamble the right to self-determination cannot be mentioned, not even if it is on the grounds of this right that the ties within the Kingdom are being maintained'. Within the Ministry of Union Affairs and the Overseas Territories the realisation had also dawned that it was unnecessary, even unwanted, to stubbornly continue resisting the recognition of the right to self-determination. However, this did not lead to a revision of the Dutch standpoint. In the meantime a few people began to wonder about the actual 'use' of maintaining Kingdom ties with Suriname and the Antilles. Their value to the Netherlands was 'economically not very large', 'militarilly zero, culturally dito', as a cold analysis read. ${ }^{36}$ At that point, this cynical view was still marginal, however.

In September 1952 a new Dutch cabinet came into office and the Christian democrate W.J.A. Kernkamp, the new Minister of Union Affairs and the Overseas Territories, was given the task of settling matters promptly. Talks within a small tripartite ministerial comission resulted in the 'Memorandum of New York' in the beginning of November. According to this memorandum the right to self-determination would be explicitly mentioned in the preamble, whereas the Charter itself would 'not necessarily have to be the end of the development of the relations between the three territories'. A change in this relationship could 'come about without difficulty', even though it was not indicated in exactly which manner. ${ }^{37}$

On visiting Suriname and the Antilles, Kernkamp even explained that the Charter 'can be considered as an interim phase'. The right of secession, 
on which the Surinamese had so strongly insisted, could be included in the Charter, if only implicitly. Back in The Hague, Kernkamp reported that the memorandum had been received well. However, his liberal views soon met with a lot of resistance within the House of Commons. Generally it was felt that it could not be the case that 'the constructors of a Kingdom start their statutes with the precondition that one can fly out of the Kingdom just as joyfully as one has flown in'. ${ }^{38}$ The Council of Ministers generally agreed that Kernkamp had to be held personally responsible for his expressed, liberal views. Also the Antillean government - tired of the endless discussions - was of the opinion that the right to self-determination could not be included in the Charter. Kernkamp now had to overcome this deadlock and find a compromise which would be acceptable to all three parties.

In June 1953 this assignment resulted in a new Dutch proposal, as the basis for a restart of the round-table conference. This time it was suggested that the right to self-determination would explicitly be mentioned in the preamble, but only in the sense that the countries were exercising this right by staying within the Kingdom - 'wishing to strengthen the mutual bonds within the Kingdom by virtue of the right to self-determination'. In the explanatory memorandum it was not only emphasised that the three countries accepted the new order voluntarily, but there was also reference of their ability to change the current status, since 'a revision of the Charter can come about in mutual consultations in not too difficult a manner' ${ }^{39}$ However, an indication of how far reaching alterations could be, and whether this included the right of secession, was purposely avoided.

The first round of negotiations took place in January 1954 in Willemstad, which started positively but ended in conflict due to a next round of rivalries between Aruba and Curaçao. From the Dutch side, the Aruban striving for separashon was commented upon as troublesome and absurd: 'By now Aruba is causing problems again by putting forward its demand to separate itself from Curaçao. Since the "overseas territory of Aruba" is such an insane idea, this affair seems more simple from the outside than it actually is. ${ }^{30}$ During the second round of negotiations in Paramaribo, surprisingly, the Surinamese changed their attitude: if it was not allowed to explicitly mention the right of secession in the Charter, then the reference to the right to self-determination should not be included either. So indeed the notion was deleted. Minister Kernkamp put this sudden change down to the Dutch refusal to talk about any form of structural development aid as long as Suriname was insisting on the inclusion of self-determination in the Charter. This time the Netherlands had played a well thought out game of poker, and with apparent success. 
On 20 May 1954, the suspended round-table conference recommenced; five days later the negotiations were finalised and on 3 June the results were made public. In this last phase of the negotiations all remaining hurdles were settled promptly. In his closing speech, Prime Minister Drees spoke of the positive results of the 'at times laborious deliberations' which, despite the initial disappointment with the long period that had passed since the Queen's speech in December 1942, had been a process of maturation. Drees explained that the duration of the negotiations - a full two years - was due to the depths and specifics of the problems that had been dealt with and the working solutions that had been needed to satisfy all parties. The way in which these negotiations had been carried out was, in his opinion, in itself proof that the colonial relations were over. There had been no room for working 'with old templates'. An implicit reference to Indonesia and international pressure from - amongst others - the United Nations could be heard in the Prime Minister's following words: 'A problem does not exist for those people who very simplistically have a tailor-made solution for any colonial territory, namely independence. They see no need to enquire as to the will of the people; even against that will they determine that any other solution would mean the continuation of colonialism.' He also emphasised that within the new construction not only Suriname and the Antilles, but also the Netherlands would give up 'a part of its own mastery'. Whether the Charter would fulfil expectations on all sides was a test he faced with confidence. ${ }^{41}$

The actual promulgation of the Charter occurred a full six months after the conclusion of the round-table conference. In the summer of 1954, the Dutch House of Commons accepted the draft Charter with seventy-five votes against nineteen. The unanimous acceptance by the Antillean Staten followed soon afterwards, as did the Staten of Suriname, with only one abstention and no opponents, and the Dutch Senate, with a large majority. On 15 December 1954 Queen Juliana solemnly confirmed the 'Charter for the Kingdom of the Netherlands' in the Dutch parliament. At this event the Queen characterised the statute as 'a monument of the power, that strength of mind, self-control and wisdom can produce in the midst of these turbulent times'. Even though the explanatory memorandum stated that the Charter was not to be seen as 'an eternal pact', Juliana foresaw that the relations between the three countries 'in their uneven geographical triangle' would become increasingly 'dynamic'. Prime Minister Drees used notions such as 'highly satisfactory', 'happy realisation' and 'wise policy'. The chairman of the Surinamese Council of Ministers Currie declared that with the Charter the 'colonial relationship has fully come to an end'. The Antillean Prime Minister, Jonckheer, emphasised that 'the door is now open for the political evolution of the three countries on an equal basis. ${ }^{42}$ 
On 29 December 1954 the sixty-one articles making up the Charter were officially promulgated. In the three countries within the Kingdom the statute was praised as a good compromise for all parties concerned. Abroad the reception was also favourable. The American press was generally positive; and on the grounds of the Charter, the United Nations relieved the Netherlands in 1955 from its obligation to report on the progress of the decolonisation process in its former Caribbean colonies.

The Kingdom of the Netherlands was now composed of three equal partners who, in the words of the preamble, would 'take care of their own interests autonomously, manage communal affairs on an equal footing, and accord each other assistance'. All of this on a voluntary basis. The possibility of equality however - a notion which originally had been rooted in the hope of keeping Indonesia within the Kingdom - in view of the large differences in scale, power and development had to be fictitious from the start. This has not only been regularly restated since, but had already been remarked upon during the years leading up to the Charter. In the end, this document, in the words of one of its creators, was 'no flawless legal document, but a political one'. All the same, the Charter formed not only clear proof of the Surinamese and Antillean aspirations, but also of the Dutch willingness to give these due recognition. In this process all attention had been focused on finding a middle path between full independence and a provincial status two extreme options which did not appeal to either party.

When we draw a comparison between the resolutions that were made in 1948 during the unsuccessful first round-table conference and the final Charter, we can conclude that the Charter met with the core of the wishes expressed in the Dutch Caribbean in and before 1948, that is to say the right to self-determination (if in the end only implied), the promulgation of an order that explicitly did not need to be 'eternal', the great measure of autonomy, the 'mutual' assistance, and feeling of mutual solidarity. At the same time, the Netherlands had successfully strived for a 'plain' regulation, limiting the number of affairs dealt with communally by the Kingdom, and restricting the Surinamese and Antillean influence in the so-called Kingdom institutions. Care had been taken to ensure that almost complete power over the affairs of the Kingdom remained on the European side of the Kingdom - the Charter contains a restrictive enumeration of what these affairs are, particularly nationality, defence, foreign affairs and the guarantee of good governance. Seated in The Hague, a 'Minister for Surinamese and Antillean Affairs' had the task of coordinating and promoting all common interests, with the understanding that any amendments of the Charter could only come about with the mutual agreement of all parties concerned.

A mixture of moral and largely pragmatic considerations had in this way led to the conscious creation of, as it is indicated today, the 'democratic deficit' of the Kingdom, which includes a Ministerial Council of the Kingdom - a redefinition of the Dutch Council of Ministers including a 
Plenipotentiary Minister from each Caribbean country - but lacks a controlling body on that level. That this predominantly Dutch Council retained the final say over such Kingdom matters as foreign affairs and defence-despite the institution of 'internal appeal' through which objecting Plenipotentiary Ministers can ask for special consultations within a small ministerial group - would ultimately form an important motive for the Surinamese striving towards independence. In the late twentieth century, the interference of The Hague with 'good governance' in the remaining overseas countries would turn out to be the most disputed aspect of the relationships within the Kingdom.

The constitutional status eventually found embodied a framework combining traits of a unitary state with some federal characteristics, and was thus praised as a unique structure. Still, this outcome placed the Netherlands in a somewhat awkward predicament. The Charter did indeed confirm a unique course of decolonisation, but it was with some hesitation that The Hague eventually agreed to it. A former governmental secretary regretted that 'the government at the time did not pluck up the courage to make apparent, in clear words, that the famous radio speech of the Queen [6 December 1942], regarding a more advanced constitutional status for the overseas territories, was initially and mainly meant for the Dutch East Indies'. ${ }^{43}$ That the Dutch eventually went more than half way to meet with West Indian wishes cannot solely be put down to the competence and perseverance of the Antillean and Surinamese negotiators, but was also due to raised expectations. Furthermore, the Dutch were striving to improve their tainted image internationally, as a result of the mishandled decolonisation of Indonesia. In this way the Charter became the highest legal regulation of the Kingdom, even above the Dutch Constitution.

By the time the breach with Indonesia had become inevitable, the political course of the decolonisation process in the West Indies was already so far advanced that there was no possibility of searching for radically different models. The option of the incorporation of both former colonies into the Kingdom in the form of overseas provinces - an option chosen by France in 1946 for its three Caribbean dependencies - was apparently unthinkable, and in any case beyond discussion. There is no convincing evidence to suggest that the possible consequences of such a structure were ever seriously considered in the Netherlands. Any proposals to at least reconsider the scope of overseas autonomy understandably encountered a lot of Caribbean resistance, so much so that these were not pursued by the Dutch.

The Netherlands refused to accommodate the Antillean, and especially Surinamese wishes for self-determination, since the recognition of this right could be interpreted as the right of secession, which was still considered a step too far. For the time being, Dutch policy would ensure it kept hold of its two remaining Caribbean colonies. And full independence was 
not high on the political agenda overseas; all the same, this crucial limitation met with resistance from Suriname. Frictions also ensued from the Dutch refusal to meet the Antillean and especially Surinamese wishes to conduct their own, autonomous foreign policies. The Dutch considered there to be only one Kingdom, which could only follow one line of policy in international politics - and this would be decided in The Hague.

In almost all other respects the outcome of the drawn-out negotiations lay close to the wishes of the local elites in Suriname and Curaçao - but not those of Aruba, where higher priority was given to separation from the Antillean state. In the process, the Netherlands had parted with more than was originally intended. Thus the Charter came into being, with its 'sober' structure and unique constitutional characteristics, with its inherent challenges resulting from the high level of autonomy operating under the umbrella of a Kingdom government, with its unresolved problem of a dividing line between the individual and communal responsibilities which is only alluded to, with its somehow fictive principles of reciprocity and equality. And also with its 'democratic deficit' which arose partly due to the Antillean and Surinamese partners abandoning the idea of representation in a 'Kingdom Parliament'.

Nevertheless, in a material sense, the overseas territories' right to selfdetermination had been accepted. The Charter was, as explicitly stated, 'not a pact meant for all eternity'. It could determine a status for an unlimited period of time, as well as usher in a transitional phase towards full independence, even if the latter option was not yet considered a realistic possibility. In the spirit of 1954 there would be an initial period based on trust, during which the three countries would ascertain whether the Charter was meeting all expectations. As far as future hurdles were taken into account, they were envisaged to be in the sphere of a further striving for independence by the Caribbean countries, rather than from Dutch objections concerning the chosen form of decolonisation.

Long years of consultations and negotiations had brought the administrators concerned closer together. Never before had the Antillean and Surinamese administrators so intensively consulted with their Dutch colleagues - indeed, more than that, it was during this process of decolonisation that an entity of overseas administrators and politicians developed. However, the right tone still had to be found among the increasingly intensive mutual contacts. 'Trust' was a notion that was brought to the fore with a certain regularity on the Surinamese and Antillean side; without mutual trust the intended constitutional order could never fully emerge.

For trust and respect to flourish there is a need for mutual understanding so that both parties can weigh and value their differences with empathy. In the following decades, both in Paramaribo and Willemstad it would be stated all too often that these conditions were lacking on the Dutch side. The Dutch argued that due to the size of the Caribbean territories, relations 
inevitably carried a certain inequality, and that 'overseas' there should not be an oversensitive reaction to this. After all, Suriname and the Antilles were small and village-like and of no great importance to the Netherlands; seen from that perspective, communal interests were limited.

The Charter ushered in a new era, an experiment within which positive mutual relations were essential. This was and would remain a difficult task. At the end of 1954 the Charter was confirmed by the Queen. The recordings of this solemn session reveal a remarkable insight. Whilst the Antillean representative Cola Debrot is making a speech, two Dutch ministers are involved in an animated conversation, paying absolutely no attention to the speaker. It is tempting to see in this the inherent tension symbolised: the consultations and ceremonies regarding the new constitutional order of the tripartite Kingdom, seen from the Antillean and Surinamese perspective as being of eminent importance, were, for these prominent Dutch politicians, apparently of lesser importance, a fact they did not try to conceal. This inequality of interest within and surrounding the Kingdom, combined with cultural differences and sometimes diverging attitudes towards the question of what the communal norms within the Kingdom should be, had constantly revealed itself between 1945 and 1954. This tension would become ever present in the new phase, sometimes in the background, but more often in the foreground. 


\section{The Failed Attempt at Model Decolonisation,}

1954-1975

At the time of the promulgation of the Charter, the Netherlands was a society striving to recover from the ravages of war and the loss of Indonesia, and from the consequent decline in its international status. ${ }^{1}$ Politics were dominated by the traditional Christian democratic, social democratic and conservative liberal parties. From 1958 the country was ruled by centreright coalitions, while most of the major cities were ruled by centre-left coalitions. This in reality would make little difference: politics was generally handled by elites who cooperated in accord with one another, while their rank and file were still expected to stick to their own sociopolitical group. Not only politics, but also the education system, labour unions and leisure were driven by the logics of ideological or religious networks, with the pinnacles of each network linked at the top by the logics of consociation. All was dictated by the drive for economic growth and the longing to become a reliable Atlantic partner. This left little room for polarisation in either the ideological arena or in class relations.

The model most certainly worked with respect to the rapid post-war economic recovery. This growth sparked a dramatic surge in mass consumption, rising levels of educational participation and achievement, further urbanisation and secularisation, and countless other knock-on effects. Amidst this rising prosperity in the Western world, a certain disenchantment with the established political systems and cultural values arose, particularly among the generation coming of age in the 196os. In the Dutch case, this would also have significant consequences for Caribbean policies.

Initially, this fresh perception of world politics resulted in fairly widespread criticism of the remnants of old European colonialism and the U.s. role in Vietnam and Latin America, in a drive to recognise development aid and a reordering of the world economy as legitimate issues on the international agenda. Increasingly, Dutch politicians began to think of their country in terms of a progressive nation with a mission to lead the way. Meanwhile, Dutch politics itself would change fundamentally, moving to the left within the extant political spectrum, and removing many of the sedate and authoritarian elites across the political framework. In the wake of this modest 'cultural revolution' - after all, Dutch culture has hardly ever allowed for revolutionary changes - after fifteen years of conservative rule, a leftist coalition came to power in 1973. A revision of Caribbean policies was now inevitable.

As the Charter was adopted in 1954 generally there seemed very little 
awareness or consideration as to what the future would hold. This complacency was only compounded by the United Nations consenting to the new status of the Dutch Caribbean. Yet, although the new order had been laid down in a Charter with a higher legal status than the Dutch constitution, the new relations within the Kingdom were only an experiment which needed to prove itself in practice. On all sides there was great political will to make this experiment work. At the same time the Dutch government was firmly of the belief that the Charter constituted the limit to which it was prepared to go. This came particularly to the fore in the repeated refusal to give up any responsibility for foreign affairs to the Caribbean countries; a desire especially nurtured in Suriname.

Even though this issue would lead to another round-table conference in 1961 , the Dutch government would not make any real concessions. The conference only served to reaffirm The Hague's position that it would have the final say over all foreign affairs relating to the Kingdom. Suriname and the Antilles, so The Hague reasoned, could not have it both ways: either they accepted the system as agreed to in the Charter, or they had to opt for independence. Although the latter option was always open, this possibility was not pursued by either the Netherlands or the Antilles, and in Suriname it could count on only little and rather ambivalent support. Other political options, such as the incorporation of both Caribbean countries into the metropolitan area as overseas provinces, were never seriously considered. The newly defined countries were totally unwilling to relinquish their recently acquired autonomy. The Hague, meanwhile, felt no interest as yet in rocking the boat.

If during the previous period most attention had been focused on shaping the political relations, after 1954 the core of transatlantic focus moved into the sphere of development aid. Dutch aid to Suriname had already become an important element in their relationship during the preceding period. This now came into effect for the more wealthy Antillean islands as well. From the mid-1950s the islands faced great economic difficulties, making Dutch support indispensable. Under the Charter the stronger country - the Netherlands - was obliged to assist the more vulnerable ones. The islands started to benefit, but soon discovered, as had Suriname, that the growing dependence on development aid could bring with it a significant limitation of their autonomy.

In a political sense, the period $1954-1975$ is quite easily subdivided. In the years between 1954 and 1961 the first experiences with the new legal order were gained. The round-table conference of 1961 sealed the Dutch unwillingness to broaden the autonomy granted by the Charter any further. The period from the round-table conference until 1969 was a relatively peaceful time for transatlantic relations. However, violent riots in Curaçao, on 30 May 1969, ushered in a new era. After trinta di mei the Dutch government quite suddenly moved to the active pursuit of independence for its 
Caribbean territories. This urge found crucial support in Suriname, which resulted in the transfer of sovereignty in 1975. With this the Kingdom was reduced to the Netherlands and - for the time being - one single remaining Caribbean country, the Netherlands Antilles.

Outside the political arena relations developed more gradually. As far as economic and administrative assistance was concerned, the territories continued to grow more dependent on Dutch aid, bringing with it increased Dutch involvement. However, since the Charter left the Netherlands little opportunity to get directly involved in the overseas administrations, over time this would only stimulate Dutch desires to put an end to the Charter and get rid of the last remnants of empire. Paradoxically, in the educational and cultural spheres this period marked a growing orientation towards the Netherlands. Increasing metropolitan involvement in so many spheres of life fueled resentment, and even decisive resistance in Suriname.

A completely new development in this period was that of migration, mainly from Suriname, to the Netherlands. Initially this movement of former colonial subjects was gradual, but the number of immigrants would steadily increase. In this way, little by little Caribbean immigration became an important element in the debate about the character and future of the Kingdom. In this chapter, the focus will be on political developments. Development aid, cultural policies and migration will be discussed at length in the closing chapters of this book, spanning the entire period from the promulgation of the Charter to the present.

A few observations will suffice to outline the institutional framework developed during this time. ${ }^{2}$ Until 1959, Caribbean policies were still developed and elaborated upon by a designated member of cabinet in the remnants of what had once been the Ministry of Colonial Affairs. To avoid the inherent connotation, its name was changed to 'Overseas Parts of the Kingdom' (1954) and later to 'Overseas Affairs' (1957). In 1959 Dutch Caribbean affairs were added to the portfolio of the Deputy Prime Minister, since it was generally felt that under the Charter there was no rationale for the Ministry's continued existence. Due to the reduction in workload there seemed little point in maintaining a specific Minister for Overseas Affairs. For New Guinea a solution was found within the Ministry of the Interior, until The Hague grudgingly returned this last Asian possession to Indonesia via the United Nations in 1962. The decision to allocate the Surinamese and Antillean affairs to an ordinary member of cabinet followed in 1971. With this, a new 'Cabinet of Surinamese and Antillean Affairs' was established. Like its Minister, the Cabinet would be out on a limb within the metropolitan bureaucracy up until the late-199os, when it was disbanded.

For all of the 1954-1975 period, either Christian democratic or conservative liberal members of cabinet held the Caribbean portfolio. This would have little resonance, as ideology only counted at the end of the period under discussion. During the previous period parliamentarian involvement 
had been limited to only a few debates each year. This has changed since the 1960 . If only because transatlantic flights became more commonplace, visits each way by parliamentary delegations and civil servants increased. With these closer contacts Dutch knowledge - although not necessarily understanding - of Suriname and the Antilles was enhanced.

Meanwhile, in The Hague, Suriname and the Antilles each appointed a Plenipotentiary Minister to the Kingdom government. Being composed of the Dutch cabinet plus these two Caribbean members, for all practical purposes this Kingdom government rarely spent more than one hour per month discussing issues pertaining to the Caribbean countries. On relatively few occasions serious differences of opinion arose, allowing the use of the institution of 'internal appeal' as laid down in the Charter, which enables the Kingdom cabinet to be broadened with one or two members of both Caribbean cabinets for the occasion. However, this appeal, a last ditched attempt to find agreement, would never produce a decision other than the one pursued by the Dutch from the start.

The function of Governor, being the local representative of the Crown as well as head of the local government, was upheld throughout this period. Of importance was the transition from a metropolitan to a native Caribbean Governor in the early 196os, an obvious reform perhaps, but one which was nevertheless hotly contested by the departing Dutch officials. In Suriname, the position of Governor was replaced by that of President with the transfer of sovereignty on 25 November 1975. As a token of a much hoped for continuity, the last Governor appointed by The Hague, Johan Ferrier, became the Republic's first President.

\section{Exploring the Charter's Margins}

During the first years following the promulgation of the Charter, intergovernmental meetings were carried out in a conducive atmosphere. The Netherlands, Suriname and the Antilles were wholeheartedly dedicated to making the Charter a workable reality. Almost unanimously the Charter was considered a satisfactory departure from colonial relationships, with the expectation that it would enhance the feeling of solidarity. Contacts between ministers and members of Parliament from the three countries became more frequent, and these meetings were generally friendly and constructive. This convivial atmosphere was reflected in the tone of policy statements, speeches by dignitaries and royal visits to the young Kingdom partners.

Although this solidarity prevailed, at times the Charter forced the Dutch government to consider where the boundaries lay between the competence of the individual countries and the communal responsibilities. In case of any doubt the Ministry of Overseas Territories would assist. Still it was un- 
avoidable that during the first years difficulties arose that put the scope of the Charter to the test. Conflicts in Willemstad between the Governor and the local Council of Ministers caused an important change in the Governor's status and the way in which he was able to exercise his authority. Partly due to Kingdom interventions it became clear that within the new constitutional order, the Governor could no longer carry out his will, but instead was limited to a role comparable to that of a constitutional monarch within a parliamentary democracy. The Governors involved complained bitterly of this erosion of their position. More importantly it had become clear that, if necessary, The Hague would not hesitate to give great weight to the notion of good governance. ${ }^{3}$

Although events in the Antilles in 1955-1957 gave rise to political conflicts about the boundaries between national autonomy, the competence of the Governor and the responsibilities within the Kingdom, it was Suriname that in February 1959 took the initiative to begin a new round of consultations focusing on a fundamental change to the Charter. In hindsight it is remarkable how quickly the round-table conference would come about. In the beginning of 1960, the Governor of Suriname, Jan van Tilburg, still reported that in Suriname 'there is little evidence of clear wishes for an amendment of the Charter or the basic regulations at this time'. Jopie Pengel, chairman of the Staten and leader of the Afro-Surinamese coalition party Nationale Partij Suriname (NPS), had also made clear that 'in Suriname we are content with the manner in which the Charter is functioning. ${ }^{4}$ Even so, as early as the spring of 1961, a conference would take place regarding the Surinamese wish to increase its influence in the field of foreign policy. This wish, although prevalent for some time, had gained impetus in this period due to international developments. Around 1960 many African countries, originally colonies and politically way behind the autonomous Suriname, had gained their independence. At the same time negotiations were taking place regarding the granting of sovereignty to the British Caribbean colonies, possibly under the umbrella of a 'West Indian Federation'. Consequently, the Charter lost some of its progressive shine. Its image was further tarnished due to Dutch abstentions within the United Nations regarding motions condemning South Africa's apartheid regime. The impotence of Suriname and the Antilles to make their own voices heard had become painfully clear.

Domestic political motives, especially from within circles of the AfroSurinamese NPS, strengthened the Surinamese bid for more autonomy. Nationalism was growing, Surinamese graduates who had recently returned from the Netherlands played a crucial role. This group of young people made fierce attacks on the Netherlands and the Charter, which NPs-leader Pengel could not afford to ignore. His ensuing nationalistic rhetoric - demanding to fundamentally discuss the Charter - resulted in the government under Prime Minister S.D. Emanuels shifting and pleading for a revi- 
sion of the Charter, the aim being for Suriname to conduct its own foreign policies.

The Surinamese argument that the conference should deal with the future, found only lukewarm support in the Antilles. The Antillean authorities had reacted sneeringly: 'Already for over a hundred years Suriname is a country of the future. We, however, are a country of the present; it is in our interest to preserve the prosperity we possess. ${ }^{5}$ The Hague also felt little need for a new conference regarding Kingdom regulations. Although the Charter was not introduced as an 'eternal pact', The Hague preferred to gain a little more experience with it first. Nevertheless, when it became clear that Suriname was making serious preparations, in March 1961 Prime Minister Jan de Quay travelled to the Caribbean, together with his Minister for Surinamese and Antillean Affairs Henk Korthals, for preliminary talks. Only two months later the new round-table conference would commence in The Hague - with a somewhat stalling Antillean prime minister.

In fact, at the beginning of the conference, on 29 May 1961, The Hague was still in the dark as to what Suriname was hoping to gain from the talks, largely due to the fact that the Surinamese were divided within their own ranks. During the course of the consultations, the Hindustani vHP (Verenigde Hindostaanse Partij), which initially had sided with the Afro-Surinamese nationalistic stance, would gradually withdraw its support, while in The Hague the Surinamese proposals were regarded as mutually conflicting. ${ }^{6}$ On the one hand Paramaribo wished to be autonomous in the field of foreign affairs - through domestic representations in the region and an independent membership of international organisations - and on the other it wished to maintain ties within the Kingdom, in particular defence as a 'Kingdom Affair'. These conflicting wishes were equated in The Hague to those of 'the grown-up son, who completely goes his own way, but when things become difficult, father has to step in'? The Dutch viewpoint was clear: foreign affairs conducted independently implied a sovereign status or at least something in the direction of a dominion status, after the British Caribbean example. Within the existing construction separate foreign policies were deemed impossible; agreeing to this proposal would imply that Suriname would also have to become responsible for its own defence and thus must become a sovereign state. The Dutch strategy was to react favourably and to not put the slightest obstacle in Suriname's way, should the proposal for sovereignty come up for discussion.

After a week of laborious debate on the question of how to find a solution that would reconcile the mutually excluding wishes, it became clear that these wishes could indeed only be realised with full sovereignty. As this was not Suriname's aim the conference soon fell apart. Not only had the Hindustani party distanced itself completely from the earlier political line, objecting to radical changes in the existing structure, but also the Afro-Surinamese NPs had become divided. Meanwhile the (token) Antil- 
lean delegation remained aloof - Prime Minister Efrain Jonckheer considered a change in the Charter completely inappropriate. The first round of talks was concluded by allowing a select group to explore the possibility of a 'Core Charter', for which the Surinamese had pleaded. Initially, however, the assignment was to study the feasibility of realising Surinamese wishes within the existing structure of the Kingdom. This made it clear that full sovereignty was indeed not something strived for, not even on the Surinamese side. Jonckheer remarked that the conference had ended in an 'impasse'. Real decisions had not been taken. Yet the delegations parted with the expectation that an end to the existing Charter was in sight, at least for Suriname. ${ }^{8}$

Soon after this the tide began to turn. Although Paramaribo had proposed a continuation of talks to begin in February 1962, this appeared unfeasible, not least because of Surinamese discord at home. The Kingdom relations had become a controversial issue within the coalition. The VHP organised demonstrations in support of the Kingdom ties, arguing that Pengel and his young nationalists had made excessive demands during the conference. When at the same time the NPS was criticised by left-wing AfroSurinamese nationalists, who blamed the party for the failure of the conference, a complex situation arose. In the absence of concrete results materialising from the conference, Eddy Bruma c.s. founded the nationalistic Partij Nationalistische Republiek (NPR), which strived for full independence as of 1 July 1963. Possibly as a defensive reaction to this, Pengel published an article in November 1961 in which he demanded sovereignty in the near future. That Pengel indeed longed for independence at some stage seems a reasonable conclusion, yet whether he seriously considered the transfer of sovereignty in the short-term remains a matter of dispute. ${ }^{9}$ This move would in any case further alienate the vHP, so that the determination of one nationwide Surinamese viewpoint became virtually impossible.

Even though Minister Korthals believed that a rapid Surinamese independence was undesirable, under his guidance The Hague initiated the construction of a secret plan, designed to transfer sovereignty to Suriname in phases, possibly also to the Antilles. Via the intermediate stage of a Core Charter, according to which the Caribbean countries would take care of their own foreign affairs within a constitutional relationship with the Netherlands, in a final stage full independence would be reached. The underlying intention was that the initiative would originate in Suriname itself, and that the Netherlands would not be seen as patronising: 'Independence will come as the ultimate goal for Suriname, so that the Netherlands cannot be blamed for excluding this possibility, thus avoiding a great deal of uncertainty. ${ }^{10}$

Yet pressure was off. Again, Suriname pleaded postponement of the round-table conference, this time until after the elections of summer 1963. Further consultations seemed politically inopportune for Pengel, who had 
been scared off by developments in British Guiana, where a 'communist' victory in the elections had led to British military intervention, and where ethnic, Creole-Hindustani tensions cast a long shadow. In this way the 'adjourned' conference would be postponed ad infinitum, resulting in a true anti-climax. The Netherlands left the initiative for further developments concerning the Charter in the hands of Suriname - and the Antilles - and did not insist on follow-up consultations. Apparently, at that moment the transfer of sovereignty to Suriname was not a priority for The Hague. It is very plausible that a completely different history would have been written if The Hague had indeed laid all of its cards on the table.

In the following years Caribbean involvement with foreign policy would remain very limited. Nevertheless, this issue, along with the possibility of an individual Surinamese and Antillean membership of international organisations, would regularly re-appear on the political agenda of the Kingdom. A fundamental debate was not resumed until the early 1970 .

\section{Turning Point: The 1969 Curaçao Revolt}

After the adjournment of the round-table conference, the Kingdom relations experienced a period of tranquility and stability. In the end the tripartite consultations were never resumed, the post-conference study group died a gentle death and the Dutch plans for a Surinamese transfer of sovereignty were quietly recorded in the archives. The Kingdom's agenda of the 1960 s was dominated by a gradual intensification of development aid, whilst The Hague expressly stayed clear of involvement in Caribbean 'internal affairs'. The three countries were not interested in a new revision of Kingdom relations. This situation was considered satisfactory to politicians on both sides of the Atlantic.

Generally, until 1969, the Dutch 'West Indies' attracted little political attention and therefore evoked little discord in The Hague. Almost unanimously government policy was praised as a generous and flexible interpretation of the Kingdom relations. Personal contacts remained lively and pleasant too. The tenth anniversary of the Charter would only procure laudatory words within the Dutch parliament and several parties would extol the Charter as a workable instrument, but certainly not an 'eternal pact'. The Charter's role as a means to guide Suriname and the Antilles towards economic independence was emphasised. Generally, The Hague showed prudence and consensus towards the Dutch Caribbean. Everything seemed calm for the time being.

The revolt of 30 May 1969 would cause a decisive reversal in Dutch Kingdom policies. Shortly before the Curaçaoan uprising, Surinamese strikes and the resulting fall of the Pengel administration had already led to some unrest in the Netherlands. During the parliamentary debates on the causes 
and implications of the Curaçaoan revolt, the Surinamese problems would gain yet more weight. An increasingly radical Surinamese nationalism added an extra dimension. Slowly but surely The Hague moved towards a policy aimed at granting independence to both Caribbean countries.

The immediate cause of the premature fall of the Pengel administration - which had only been in office since 1967 - had been the lengthy strikes by teachers demanding wage increases. ${ }^{11}$ By then, Pengel's position had already weakened due to the break with Jagernath Lachmon's vHP, whilst he had had to deal with the unabated leftist opposition within his own AfroSurinamese circle. Pengel's eventual fall was not something mourned over in The Hague - not only had his style of government and unpredictable behaviour provoked growing resistance, but there had also been concrete reasons for Dutch concern. Two affairs in particular drew heavily on the Kingdom relations. Initially there was the flaring up of the border conflict with Guyana, originating in colonial times, but escalating now due to the placement of Guyanese army posts in disputed territory. Pengel, apparently dissatisfied with the Dutch passive attitude, formed a 'Defence Police', charged with the protection of the Surinamese territory - and therefore of the Kingdom. According to the Charter, defence matters were in actual fact the responsibility of the Kingdom. In 1967 and 1969 light skirmishes took place in the border region. Reports that Venezuela, which was also involved in a border conflict with Guyana, secretly had delivered weapons to Suriname, had only furthered Dutch concerns.

Secondly, Pengel had also tried to involve the Netherlands in the strikes, which according to the Charter were an internal affair. Not only had he asked for financial support, but also, to the shock of the Dutch government, hinted at the possibility of making an appeal to the Kingdom to intercede. In the end it would not come to this; with Pengel's fall and the election of a more prudent cabinet under Prime Minister Jules Sedney, a period of relative calm returned. However, due to this episode, the realisation had dawned that the Netherlands, against its own will, could become involved in the internal and external conflicts of Suriname. Left-wing parties already drew far-reaching conclusions: The Hague would have to take the initiative and amend the Charter, so as to prevent unexpected and undesired surprises arising from the Kingdom structure. The possibility of the Charter's termination should also be considered. This vision was considered as paternalism by the centre-right parties in office, but the social democrats began having serious doubts concerning the Charter as well.

On 30 May 1969 Curaçao's capital, Willemstad, was burning. A labour conflict had ended in a revolt in which suppressed feelings on unequally divided prosperity and racial barriers found their release. Dutch Marines were brought in to restore order. When the smoke cleared, it revealed part of the historical city in ruins. The revolt's consequences in the long term would be far-reaching. ${ }^{12}$ 
Whilst a furious and almost uncontrollable crowd marched on Willemstad, local police failed to seal off the city. The fact that both the Governor and his Deputy, as well as the Antillean Prime Minister Ciro Kroon were absent while the rioting was taking place, only complicated events. Therefore the request for Dutch military assistance from the Dutch was made by lower ranking officials. The revolt was escalating so rapidly that improvisation was the only course. Events unfolded in quick succession. The invocation of military assistance by the Kingdom meant the deployment of the Royal Marines, quartered in Curaçao. By midday of the $30^{\text {th }}$, one hundred Marines were at the disposal of the Antillean government, and actual intervention started soon afterwards. Only after the insurgence of the Marines would the Kingdom Council of Ministers - during an emergency meeting the next day - give formal approval to this granting of military assistance. Immediately, another three hundred Marines left the Netherlands to assist their local colleagues. They would return home one week later. The use of Marines had resulted in a short and decisive end to the revolt. ${ }^{13}$

On 3 June 1969, Dutch parliament held emergency consultations regarding the situation. Few words were wasted on procedures. The conclusion drawn by both coalition and opposition parties, with the exception of the far left, was that there had been no other solution. Much attention was focused on the dilemma of having a constitutional relationship which obliged the Netherlands to offer military assistance, but which denied any scope for remedying the source of possible tensions. However, since it was to be avoided that the Antilles should feel the Netherlands was about to let them down in these difficult circumstances, the coalition parties considered it unsuitable to raise the issue of the Charter itself at that moment.

Within the left-wing parties reactions were considerably more critical. Not only was there criticism concerning the granting of assistance to a regime with little support in The Hague, but also regarding underlying constitutional factors. In every possible way the outdated nature of the Charter was emphasised. There was particularly severe criticism of the paradoxical obligation of the Kingdom to guarantee good governance in the countries concerned, whilst at the same time leaving the responsibility for the quality of government as much as possible to the countries themselves. Following the military intervention, little was done locally to reduce the possibility of renewed unrest - leaving the Netherlands open, once again, to dealing with problems beyond its control. The parties of the left now expressed the need for the ending of transatlantic ties to be put firmly at the top of the political agenda.

Whilst Dutch coalition parties had reacted rather approvingly to the intervention, the response of the press was clear and more consistent with the left-wing stance: the Kingdom relations required a thorough revision. After all, it was not only on Curaçao that things were brewing, but also in Suriname, as Pengel's fall had made clear. At a later stage the views of the 
press also gained ground within government - partly fuelled by concerns regarding the Dutch image. The belief that the Dutch intervention had been misunderstood by the outside world as a neo-colonial action, played an increasingly important role. It was argued that the international press had prominently featured the military intervention. Images of Dutch Marines patrolling the smouldering ruins of Willemstad, machine guns at the ready, had been transmitted worldwide. With little understanding of the Kingdom relations and the nature of the Charter, the world inevitably witnessed colonial intervention. ${ }^{14}$ In hindsight this concern needs to be understood above all as a typical Dutch overestimation of the interest existing abroad for the way the Netherlands acted within its own sphere of influence. Yet this concern would be instrumental in the new Dutch approach to the Kingdom relations.

Chance took care of the rest. In the same period as the military assistance on Curaçao, a debate on the earlier military actions in Indonesia flared up in the Netherlands, due to the exposure of secret information on committed excesses. ${ }^{15}$ The connection was all too easily made. No more excesses and no more 'colonial actions' had to be the resolution. Had once again the military assistance been granted to the wrong party? Would, in hindsight, conclusions be made that the Dutch had misunderstood public feeling in the Antilles? Clearly the answer lay in a concerted effort to find a definitive solution to the post-colonial issue: the dismantling of the transatlantic Kingdom. In the months and years after the Curaçaoan revolt this new view found wide support within Dutch politics. A new debate now began which would end, six years later, in the independence of Suriname.

One year after trinta di mei - May 1970 - the commission appointed to investigate the background and causes of the riots published its report. ${ }^{16}$ The events, so the commission concluded, had been of an 'unexpected character' - all theories that the uprising had been premeditated were brushed aside. The commission pointed at socioeconomic and, closely connected, racial tensions within Curaçaoan society as the underlying factors. Even though in the 196os Curaçao was not a poor island, the Antilleans were disappointed that their high expectations regarding prosperity had not been realised. In addition to this, there was a visible racial disparity in the distribution of incomes, which in turn had its inevitable social implications within society's hierarchy. The commission's observations were made from a local perspective, in other words related to the 'internal affairs' of the Antilles, or rather of one of the Antillean islands. Both the problems and the commission's recommendations for improvement were therefore not concerned with a possible revision of Dutch policy. However, the commission expressed itself - prudently - regarding the functioning of Antillean politics, and a few points were raised which implicitly reflected Dutch policy. These included the relationship between the Antillean state and the individual islands, and the appointment of the white Democratic Party leader, 
the former Antillean Prime Minister Jonckheer as Governor of the Antilles, a few weeks before the riots.

The commission tentatively discussed possible constitutional changes. Once again these were options for Antillean policy, although the considerations were equally relevant to the Netherlands. The commission pointed at the 'paradox of wishes', at least among Antillean nationalists, that was formed by the wish for both constitutional independence and the development towards a prosperous nation. It was suggested that this was an illusion. In view of the experiences and prospects within the Caribbean, political independence would almost certainly equal economic decline; conversely, for an increasing level of prosperity, Dutch support was deemed indispensable.

It is difficult to establish to what extent these findings played a role in policy determination on both sides of the Atlantic. However, it can be concluded that during the following two decades, Willemstad would in no way be guided by this 'paradox of wishes'. The issue of political independence could be erased from the agenda, as far as the pragmatic Antillean government was concerned. The Netherlands, in turn, seems to have ignored or even denied the paradox for a long time, since it could frequently be heard in The Hague that political independence was a precondition for satisfactory economic development of the former colonies.

In reaction to trinta di mei a fundamental change in Dutch policy became apparent; no longer did The Hague categorically refrain from intervention. Dutch reassessment regarding the appointment of a new Governor to the Antilles was symptomatic of this. The Governorship of Democratic Party leader Jonckheer was now regarded as an unfortunate choice, which had become apparent in the heated protests of 30 May - in as far as the revolts had been a political protest, this had mainly been aimed at the Democratic Party's hegemony. Jonckheer's appointment was repealed and in his place came the first black Antillean to hold the office of Governor, the Afro-Curaçaoan Ben Leito. In this way the Netherlands supported a 'progressive' development - emancipation of the Afro-Antillean population - whilst at the same time it took a 'regressive' step - breaking with the custom of accepting the candidate proposed by the Caribbean government. Not without reason the Democratic Party experienced this as a significant attack on autonomy and, with this intervention, The Hague had placed itself between parties, whilst its intention was in fact to distance itself from Antillean politics.

The Hague believed that it was time for political action. In Willemstad in January 1970, on the initiative of the Netherlands, Kingdom consultations recommenced. Minister for Surinamese and Antillean Affairs Joop Bakker held meetings with both overseas Prime Ministers: Jules Sedney for Suriname and Ernesto Petronia for the Antilles. Clearly the two were in no hurry. Before being able to form an opinion on possible constitutional changes, 
Petronia claimed he had to await 'further national and island consultations'. Sedney was more outspoken, stating that 'the acquisition of full constitutional sovereignty will not be the main issue for this governmental period' ${ }^{17}$ Bakker emphasised that the Netherlands would not unilaterally attempt to change the Charter. Later Bakker recalls that during his ministership (1967-1971) Dutch policy was characterised by 'no pressure in the direction of independence from our side. We wanted independence to be a free choice, not exacted by the Netherlands. If they did not want that independence, then all well and good, we would stay together, in the same family. The studies undertaken were based on the assumption that The Hague would need to know what had to be done, just in case it would ever happen. ${ }^{18}$

The left-wing parties sustained their critical standpoint regarding government policy, a social democratic member of parliament declaring on behalf of these parties in May 1970: 'It is really a duty of the Netherlands to give an opinion, and that opinion appears to be the two West Indian territories having to become independent within a reasonable term. ${ }^{19}$

In July 1971, with the coming into office of the centre-right Biesheuvel administration, the emphasis had indeed somewhat shifted, the government stating that the Netherlands 'could also take the initiative to amend the constitutional status of the countries'. Whilst the ongoing Kingdom consultations only made slow progress, in August 1971 a Dutch parliamentary delegation to the Caribbean set the cat among the pigeons. Even before their departure, the social democratic opposition spokesman Theo van Lier had declared, not very tactfully: 'The Netherlands should act as a swimming instructor who at a certain moment has to tell his pupils: "And now into the deep end."' ${ }^{20}$ This message caused fierce reactions overseas, particularly in the Antilles, where former Prime Minister Kroon declared: 'The standpoint now put forward by the Dutch delegation, is for me a bolt from the blue. However, I am of the opinion that if the Netherlands should take this initiative, it needs to be considered as a form of paternalism. ${ }^{21}$ Yet in November 1971, the Dutch House of Commons announced for the first time, and with an overwhelming majority, its support for the transfer of sovereignty to both Caribbean countries.

Consequently, on 5 January 1972, a tripartite advisory 'Kingdom Commission' was established with the task of indicating 'feasible alternatives for the existing constitutional relations'. On 27 March the commission was officially installed by Minister P.J. Lardinois, the then Minister for Surinamese and Antillean Affairs. At the following conference - the first of what would turn out to be four plenary meetings - it became immediately clear that the questions of nationality, development aid and defence would become very thorny problems after a possible transfer of sovereignty. In particular, the maintenance of Dutch nationality and development aid appeared to be a strong Surinamese and Antillean desire, along with the 
option of a permanent right of abode in the Netherlands.

As a result of the first discussions, Minister Lardinois expressed doubts in cabinet about the feasibility of granting independence in the near future. In accordance with decisions taken at the second meeting of the Kingdom Commission, August 1972 in Paramaribo, the Dutch section published a concept for a 'Light Charter'. The explanatory memorandum mentioned a transition to 'sovereignty for each of the countries within the foreseeable future'. Minister Lardinois welcomed this intermediate solution, since a direct transfer of sovereignty appeared unobtainable. Within the new Charter 'bottlenecks' would be removed and a provision made for 'the possibility for each country to end the Charter unilaterally. ${ }^{22}$ However, Dutch expectations regarding this 'Light Charter', followed by a full transfer of sovereignty, turned out to be wishful thinking. In March 1973, during the Kingdom Commission's third plenary meeting in Willemstad, Surinamese and Antillean memoranda rejected Dutch proposals. A stalemate followed; the bid for a termination of the Kingdom relations had very clearly revealed itself to be essentially a Dutch goal. The aversion to a possible recurrence of military intervention had remained large after the days in May 1969, and had led to many in The Hague declaring the Charter to be flawed, and thus only an intermediate stage in the direction of full independence. Shortly afterwards, May 1973, the Biesheuvel government fell. Following this, developments would gain momentum at a surprising rate, in view of the preceding history.

\section{Negotiating the Independence of Suriname}

The centre-left Dutch cabinet under Prime Minister Joop den Uyl (a coalition of the three progressive parties, PvdA, D66 and PPR, along with the christian democratic parties KVP and ARP) would adopt a new, pro-active line towards the Dutch Caribbean. ${ }^{23}$ In its government declaration of 28 May 1973 it announced that, following advice from the Kingdom Commission, the government would start talks with Suriname and the Netherlands Antilles 'in order to reach a final decision regarding the timing of independence for these countries'. The path was now open to realise one of the main objectives in the progressive political programme: 'Suriname and the Netherlands Antilles will become independent during this administration, therefore prior to 1976.' The ARP, one of the confessional coalition parties, had already in 1971 published a report which had strongly argued for sovereignty in the near future for both Caribbean territories.

With the coming into office of the den Uyl administration, for the first time in history Dutch decolonisation policy in the Caribbean would become a policy in which political colour made a crucial difference. That difference was made by a 'left-wing' agenda. Although the cabinet aspired to 
handle decolonisation policy with vigour - den Uyl believing that 'only in independence, possibilities remain for the improvement of the existing social structure of Suriname', and Minister for Development Aid Jan Pronk reasoning that development aid 'is one of only a few important means of leverage open to the Netherlands to bring independence closer ${ }^{24}$ - it had in fact inherited a stalemate. The activities of the Kingdom Commission had come to a standstill. Even though the model for transferring sovereignty in phases had been developed and recommended by the Dutch, neither the Surinamese nor the Antillean government were actually prepared to follow its course. The first Dutch priority thus lay in the fostering of overseas support for the realisation of its own policy intentions. Growing concern about ongoing Surinamese immigration only strengthened the alluring prospect of Caribbean independence. With apparent frustration den Uyl noted in January 1974 that 'in Suriname it is still not believed that the Netherlands is serious about the necessity of the territories becoming independent in the foreseeable future'. ${ }^{25}$ Meanwhile, the Dutch press and public opinion also demonstrated strong desires that the Caribbean territories should quickly become independent. Ironically, this Dutch impatience for a swift transfer of sovereignty, in the end mainly exacerbated the migration problem.

The breakthrough came from Suriname, with the declaration of incoming Prime Minister Henck Arron on 15 February 1974, stating on behalf of the 'National Party Combination' (a joining of Afro-Surinamese parties and the Javanese KTPI, which had come into office in November 1973) that Suriname would accept independence before the end of 1975. With independence suddenly looming on the horizon, great unrest and insecurity developed within Suriname; conversely the declaration was welcomed in The Hague with considerable satisfaction. When den Uyl arrived in Paramaribo only five days later - the trip had been planned before, and some believe that the timing of Arron's declaration was aimed at outpacing the Dutch government - he immediately commented that although 'the estimated time appears short', he was 'personally happy' with the announcement. Suriname, according to the Dutch Prime Minister, could count on a 'special aid relationship' after independence, although this could not come in the form of a 'blank cheque. ${ }^{26}$ Whilst the Surinamese cabinet took the opportunity to pressurise den Uyl not to put the slightest obstacle in the way of Suriname's independence, the - Hindustani dominated - opposition pleaded for postponement. Opposition leader Lachmon, considering independence premature in view of the protection of democracy and human rights, argued for a transitional period of a further ten years. At an earlier stage Lachmon had already stated that he 'could not accept independence as long as the Surinamese have not formed a true nation. Independence in the short-term will only bring chaos.' Den Uyl's reaction was resolute: a transitional period of another ten years was beyond discussion, precisely 
due to the government declaration, which marked a 'point of no return'. ${ }^{27}$

With both Surinamese parties taking opposite and uncompromising standpoints, it comes as no surprise that den Uyl sided with the like-minded government. He showed foresight when he mentioned the probability that 'the prospect of independence in the near future will further stimulate the emigration stream. ${ }^{28}$ However, in Paramaribo this warning was primarily regarded as a Dutch problem, and thus fell on deaf ears. Instead, from the Arron administration came the wish that 'The Hague takes care that Suriname will be supported in such a way that independence can be a celebration'. Back at home den Uyl swore that a delay of Suriname's independence would 'surely lead to problems'. ${ }^{29}$

When shortly afterwards Minister for Surinamese and Antillean Affairs W.F. 'Gaius' de Gaay Fortman visited Suriname, it also became clear to him that the cabinet under Arron 'is indeed serious about obtaining independence in the near future'. De Gaay Fortman had gone to great lengths in his attempt to get the opposition leader in line with Arron, warning Lachmon 'that it is wiser to cooperate with the realisation of sovereignty than to put things off out of fear, since after all his involvement will be unavoidable at a later stage'. To den Uyl's dissatisfaction de Gaay Fortman believed that the intended deadline - 'before the end of 1975' - would be unfeasible, at least 'if one wants to regulate things well'. Apparently he 'had not said this in Suriname'. Referring to the ethnic-political tensions, within the Dutch Council of Ministers de Gaay Fortman did stress the importance of 'Suriname not being left in chaos. The Netherlands is equally responsible for the presence in Suriname of the Afro-Surinamese as of the Hindustani.' Minister Pronk, on the other hand, believed that in Suriname den Uyl had been overly reserved regarding Prime Minister Arron's plans. ${ }^{30}$

In May 1974 the first, tripartite, consultations took place in The Hague, resulting in the revival of the Kingdom Commission and only three and a half months later in the publication of its report on the preparation of Suriname's independence. ${ }^{31}$ Apart from advice on various related subjects, the report contained a meaningful disclaimer: the Antillean section of the commission had stated explicitly that it did not consider the findings, which at present were only affecting Suriname, to be applicable to the Antillean islands, neither in the present nor in the future. On the important matter of citizenship, the Kingdom Commission had rejected the option of dual nationality. Instead it was argued that the country of residence should be the criterion: those who were born in Suriname following independence, and those still living there at the time of the transfer of sovereignty, would automatically get the new Surinamese nationality - those at the moment of independence living in the Netherlands or elsewhere would remain Dutch. On the issue of development aid the commission referred to the Protocol of May 1974, in which the Netherlands 'agrees to maintain, also once independence is established, a special responsibility for the development of Suri- 
name. ${ }^{32}$ It was typical of domestic political discord that the commission needed to add four minority memoranda to its report, all of which had been formulated by the Hindustani opposition. ${ }^{33}$ Objections primarily concerned the proposals for conferring nationality. With allegedly 'at least $75 \%$ of the Surinamese population not being prepared to give up Dutch nationality just like that', and the swift rise of migration to the Netherlands, a referendum on nationality was recommended. All objections gave strong evidence of resistance towards the imminent independence.

Following the publication of the Kingdom Commission's report, the actual bilateral consultations could commence. Between October 1974 and June 1975 five conferences took place, alternately in The Hague and Paramaribo. On the Dutch side the feeling arose that it was preferable to do business in The Hague rather than in Paramaribo, where, as the reasoning went, the Surinamese negotiators were under public supervision and had to consult with their advisors constantly.

On the night of 26 June 1975 Dutch-Surinamese negotiations were concluded with a provisional agreement, yet negotiations would continue until the very day of the transfer of sovereignty - 25 November 1975. Looking back, Pronk remarks: 'I have never experienced negotiations such as these, whereby every day the achievements of the previous day would once again be brought up for discussion. The negotiations were re-opened even during the final night before the transfer of sovereignty, and they virtually continued until we stood in the doorway of the old church. ${ }^{34}$

However, with the initiation of bilateral consultations, at the end of 1974, all of this was still in the distant future. From the start it was clear to the Dutch that many obstacles needed to be overcome. Four main 'policy objectives' guided The Hague's policy. The first matter of importance, the realisation of independence at the end of 1975, was linked to the curbing of the immigration wave, the socioeconomic development of Suriname, and the prevention of a 'bloodbath' after independence. In order to be able to reach the deadline, according to its top civil servants, the Dutch government had to adopt a hard political line. Even a Dutch unilateral secession from the Kingdom was briefly considered.

During the negotiations neither of the two governments would ever deviate from the final objective. The Arron administration remained resolute. In the Netherlands things were much more complicated. In the process The Hague placed itself between the two opposing Surinamese sides, as it believed the Surinamese cabinet failed to secure national consensus. In practice this attitude would weaken the Dutch position in relation to the party with which the eventual target was shared. During the consultations this would become all too clear; continually the Dutch were making more concessions than were originally intended.

At first glance this seems an illogical outcome. After all The Hague was, in the words of one of its advisors, 'on almost all points - with the excep- 
tion of the migration issue - the player with all the cards', whereas Arron and his cabinet 'stand in fact with their backs against the wall, fearful of new elections because their outcome, with independence as the main issue, will be certain [a dramatic loss] from the very start' ${ }^{35}$ Still The Hague did not follow a hard line during the negotiations, with the sole intent of keeping the Surinamese cabinet in office - whilst also attempting to satisfy the opposition - and reaching independence, even if it was at a high cost.

The growing migration from Suriname to the Netherlands served only to complicate matters. For the Dutch, Surinamese immigration became yet another reason to progress rapidly with the transfer of sovereignty. Much to the dismay of the den Uyl administration, the persistent migration wave was seen by Arron and his cabinet as primarily a Dutch problem. The Hague had few illusions regarding the possibility of effecting a spontaneous reversal. From a 'top secret' memorandum from the Prime Minister's cabinet it becomes all too clear that the Dutch government was well aware that the future of the republic was unsure and, to some extent due to this, curbing the Surinamese immigration wave was considered virtually impossible. ${ }^{36}$ The swift completion of the decolonisation process was thus perceived of as a vital means to curb this exodus. Hence the Dutch willingness to make concessions in other fields, particularly regarding the amount of development aid.

From time to time the agitated political atmosphere in Suriname and the feasibility of the time schedule were discussed with great concern within the Dutch Council of Ministers. However, cabinet talks on the manner in which sovereignty should be transferred, again evoke the image of a great Dutch eagerness for the desired final objective, which resulted in matters proceeding with haste rather than care. Thus, after only short deliberations, the conclusion was drawn that to confer sovereignty to Suriname no amendments in the Dutch Constitution were needed - majorities in all parliaments would do.

Despite all protests by the opposition, throughout the whole process the den Uyl administration remained supportive of the Surinamese cabinet inevitably resulting in a growing resentment within oppositional circles. In the summer of 1974 the Hindustani vHP sent a revealing telegram to the Kingdom government: 'Prevent bloody strife, liberate approx. 250,00o democrats and Dutch people from the parasitical plague of the communist NPK-leaders. ${ }^{37}$ In the course of 1975 political and racial tensions became critical, with rioting and arson in the erstwhile quiet capital of Paramaribo a regular occurrence. In the meantime, the Surinamese migration to the Netherlands, this time especially from within the Hindustani community, was reaching vast and unprecedented proportions. To complicate matters, Prime Minister Arron lost his majority in parliament, as members of his coalition had joined the opposition precisely because of the independence issue. 
Half way through the preparatory process, 15 May 1975, the Surinamese opposition in the Staten made a proclamation in which the Arron government, with its 'lowest of majorities', was reproached for treating Suriname's independence 'stubbornly' as a 'one-sided party-affair' ${ }^{38}$ Voices like these were quickly silenced. Even one of the points of principle brought forward by the opposition, namely that the republic would need to possess a constitution at the moment of independence, was a matter only urged for by the den Uyl government, rather than a requirement of the Surinamese government. Thus The Hague remained focused on a continuation of the preparations for independence, whilst attempting to win over the opposition to its cause. The lack of an openly critical Dutch involvement in the far from flawless administrative process during the tumultuous final half year before 25 November 1975 was mainly due to the Dutch not wishing to lend too much of an ear to the objections raised by the Hindustani-Javanese parties.

Understandably, the opposition asked the valid question of whether all of this was in tune with basic requirements of good governance, and whether the Netherlands - with its inherent self-interest - was in fact in a position to guarantee this. In retrospect, this question certainly needs to be addressed in a broader sense. The reality of a particularly strong social and political opposition in Suriname, forces the question as to whether the energetic preparations for independence on the Dutch side, along the very hastily mapped route, were in agreement with the requirements for good governance within the Kingdom. A crucial question, yet there is no evidence that at any moment the den Uyl government did step back for reflection. Instead, The Hague steadily assumed the role of mediator, which implied a willingness to pay a continuously higher price for independence, in the hope that in this way the opposition could, after all, be reconciled with the completion of the final objective.

Both governments may rapidly have come to an agreement regarding a transfer of sovereignty and the timing thereof ('before the end of 1975'), yet a number of controversial issues remained. Four topics in particular would lead to difficult negotiations: the aforementioned need for a Constitution; the question of whether or not the republic would need a regular army; the amount of development aid to be conferred by the Dutch; and the question of nationality, along with provisions for migration between the republic and the Kingdom.

Regarding the first issue, the likelihood that independence would come into effect without a constitutional basis was a thorn in the side of not only the Surinamese opposition, but also of Minister de Gaay Fortman, whose 'greatest concern' was independence resulting in political-ethnic strife and chaos. However, the Netherlands was no longer in a position to make any prior demands in this respect, so Prime Minister den Uyl maintained: 'The Netherlands can only urge, not force. ${ }^{3}$ Although the House of Commons 
would finally be presented with an independence bill which made no reference to a new Constitution simultaneously coming into effect with the republic, Arron would succeed in presenting the Staten - immediately before it was required to vote on the ending of the Charter - with a new Constitution, a vital part of which had been written by civil servants in The Hague. This Dutch support had resulted in a constitutional framework almost identical to that of the Dutch, both in form and content. The traditions established during the colonial and post-colonial periods were upheld. The parliamentary system was maintained with only the President taking the place of the Governor. The option of a truly presidential system had not seriously been considered, which meant that no fundamental changes were required for the Dutch system to be adopted by the new Surinamese nation. Furthermore, the Surinamese borders were described as identical to the ones of the colonial period, neglecting the fact that those borders were disputed by France, Brazil and Guyana.

Another thorny problem in the negotiations arose from the question of whether Suriname would need its own army once independence was attained. At an early stage the den Uyl administration had decided that sovereignty would end the Kingdom's responsibility for Suriname's defence, necessitating the new republic to guarantee its security through treaties with neighbouring countries. The Dutch deemed it sufficient for Suriname to establish only a paramilitary organisation, capable of curbing potential domestic unrest and of undertaking various development tasks. However, under Surinamese pressure this standpoint soon shifted in favour of the creation of a regular army. Suriname expected generous financial support towards this end. The division of financial responsibilities proved to be a matter for dispute, again resulting in at times heated negotiations. In the end, following independence, the Republic of Suriname could indeed pride itself on an independent, domestic army, partly financed with Dutch development aid. This was the outcome of negotiations in which financial differences had held remarkably more weight than considerations of principle. The whole military structure, which for a long period involved Dutch supplementary payments to soldiers transferring from Dutch divisions to the Surinamese army, would later lead to the bizarre situation that those responsible for the military coup in 1980 were receiving part of their salary from the Netherlands. In the end the Dutch government would unilaterally cease this supplementary payment.

The remaining two aforementioned contentious topics in the negotiations will be fully discussed in later chapters: development aid and migration. In a nutshell, the Netherlands started negotiations by considering an amount of around one billion Dutch guilders for the first ten to fifteen years to be sufficient, against a Surinamese list of demands which involved ten times that amount. In the end both parties would agree on an amount of 3.5 billion Dutch guilders - which adjusted for inflation equates to ap- 
proximately $€ 3.5$ million today - composed of grants, guarantees and the acquittal of debts. ${ }^{40}$ Despite some Dutch scepticism regarding the ability of the new nation to allocate this figure constructively within ten years, as Suriname intended, the amount, equalling around 10,00o Dutch guilders per capita (again adjusted for inflation, some 10,0oo euros or dollars today) was not considered excessive, even if in a comparative perspective it was indeed extraordinary. Prime Minister den Uyl would describe this 'golden handshake' as a gesture of good will and decency. A less visible - but not inconsequential - concession on the Surinamese side had been the diminishing real value of the promised sum, due to inflation. Since the spending of the promised aid was eventually shelved for much longer than was initially intended, largely due to political disagreements during parts of the $1980 \mathrm{~s}$ and 1990s, this would result in a dramatic loss for Suriname in the longterm.

Finally, on the subject of migration, standpoints were not in line. The den Uyl administration was of the opinion that the ongoing exodus from Suriname should be ended as soon as possible. However, no internal consensus existed regarding the way in which this would come into effect. In the meantime, the Surinamese government continued to treat the migration wave to the Netherlands as a Dutch problem and refused to take action. The compromise emerging from the negotiations would prove to be a drain on Suriname's human resources. Migration to the 'mother country' would continue unhindered until five years after the gaining of independence. This concession, much to the young Republic's loss, again should be understood primarily as a joint attempt to soften the opposition and to prevent Arron's position from weakening, thus securing the transfer of sovereignty.

To The Hague's irritation, the often cumbersome negotiations had made it unfeasible to discuss the bill on independence in Dutch parliament at the beginning of September 1975 as planned. The Surinamese opposition had made every effort to thwart progress. A decisive turnabout came in October 1975 with the visit to the Netherlands of the almost complete Surinamese opposition under the leadership of Lachmon - including four defectors of the coalition parties. The visit was intended to yet again express objections to the proceedings in the hope that independence would at least be postponed. Things would turn out completely differently. While Lachmon's opinions went unheeded, Dutch ministers and members of Parliament intensively - and successfully - lobbied with individual opposition members. To the bewilderment of Lachmon and his party, one of its prominent members, George Hindori, ceased his resistance to independence on returning to Suriname, thus restoring a narrow majority to the Arron administration. There has been much speculation about Hindori's motives, ranging from brave, conscientious and nationalistic to opportunistic or even 'bribed'. But it is without doubt that he took his crucial decision due to the pressure exerted not only by Arron but also by The Hague. In any case, with 
this 'desertion' the Surinamese Staten reached its required quorum - twenty members - as well as a (narrow) majority for independence - twenty against eighteen.

Procedures could now be concluded swiftly. Reluctantly the opposition parties cooperated with the inevitable. It is quite remarkable that the Dutch parliament voted on the transfer of sovereignty even before the Surinamese Staten did so. From 21 until 23 October 1975, just one month before the intended date of independence - 25 November 1975 - the bill was discussed in the House of Commons..$^{41}$ A delegation of the Surinamese Staten took part in the debate which turned out to be fierce, especially by Dutch standards. In particular the vHP members did not attempt to hide their disdain. With the telling statement 'Greetings, den Uyl, rulers, we who are about to die bid thee farewell!' vHP member Mungra underlined the unambiguous tensions between the two Surinamese parties. In his view the country was about to be abandoned without any moral sense of responsibility and the Charter would be interfered with in an undemocratic manner: 'It is depressing and extremely sad for us, that Premier Arron, with his almost unimaginable awkwardness in politics and statesmanship, has given $\mathrm{Mr}$ den Uyl ample opportunity to triumphantly kick in the door of the democratic sacristy, roaring with laughter. Now we are standing here, with dignity at the threshold, bidding farewell to you, after being abandoned and pushed into the gas chambers of terror and fascist suppression.' Mungra concluded with what in retrospect would turn out to be a wry expectation: 'Despite billions in redemption money, I predict, not being a pessimist, that Suriname is heading for a lengthy period of anarchy and decay and that our children will think back nostalgically to the golden times, when all sections of the population were living peacefully with each other, albeit in poverty, without those billions.'

Other members of the opposition protested against the absence of clearly delineated national borders: 'Where remains the good governance of the Arron government if soon we become independent without borders?' Opposition leader Lachmon expressed his hope that 'The Hague will stand in the front row, alert to the violation of fundamental human rights and freedoms, wherever that may be. In the event that this will also happen in Suriname, I make a serious appeal to you: do not close your eyes, they are your brothers, they are your people with whom you have been connected for three hundred years; attempt - along whichever path - to prevent these things from occurring there. This is the only request I have to you all.' Not surprisingly, the Surinamese coalition members adopted a conciliatory tone. Thus Nooitmeer stated 'it was more out of self-respect and national pride that this Surinamese cabinet has taken destiny in its own hands', and Staten chairman Wijntuin called on all Surinamese to help guide the ship on its course. 'Let us not try to work out who has made mistakes and who has not. Everybody makes mistakes.' Bean stressed that 'the past has taught 
us that the Surinamese people and its leaders, including Mr Lachmon, have taken every care to ensure that the Surinamese people always have been able to fend for themselves.' Finally, Derby wanted to impress upon the House of Commons that the speeches of the members of the opposition should be of no concern. 'You have to understand very well that what is being said here regarding Suriname's independence - call it manipulation, bargaining - is beginning to make me sick to the stomach, because I know that things, put forward here, are not as they truly are. ${ }^{42}$

At the third and final day of the debates, den Uyl made a remarkable summary of the debates, glossing over the strong criticism: 'It has struck me that regarding the desirability and inevitability of independence itself, there has appeared to be no crucial difference of opinion.' This resulted yet again in fierce reactions by the opposition. Still, the House of Commons adopted the bill with 106 votes in favour and only five votes against - the Dutch senate following soon afterwards with a large majority, although the number of opponents was slightly higher, largely due to the conservative liberals (VVD) not supporting the bill as long as no Constitution had been accepted in Suriname.

Confronted with the inevitable, Lachmon thereafter declared his intention to offer his loyal cooperation to further the procedure, as long as two conditions were met: the certainty of the Republic having a Constitution at the moment of sovereignty, and the organisation of national elections in the short-term. Arron agreed with these requirements, but would eventually only honour the first one - to the understandable bitterness of the opposition his promise of elections, 'within eight months', was not fulfilled. By then, however, the transfer of sovereignty had already taken place.

The final debates in the Surinamese Staten took place from 17 until 19 November 1975, again much later than originally had been intended. By then it was clear that the cabinet would reach its objective. During the debates a symbolic reconciliation took place between Arron and Lachmon. On 18 November, precisely one week before the planned date of independence, the Prime Minister invited his opponent 'to show that as the two main political figures in this country, we will undoubtedly oppose each other, in a harsh and sometimes even severe manner, but we are in no way enemies. In the first place we are Surinamers who have the duty to communally build this country. 43 These words were followed by a brasa, an embrace, symbolising reconciliation. Lachmon pronounced his appreciation for Arron's gesture but still could not conceal his scepticism.

The following day the law regarding the secession of Suriname from the Kingdom was accepted, with twenty votes for and eighteen against. However, since the opposition was prepared to give its symbolic unanimous support, a second reading - officially requested as there was no two-thirds majority - was not necessary. On the same day the constitution of the Republic of Suriname was accepted by common consent. On 13 November 
1975 the Antillean Staten had already - unanimously - voted in favour of the Charter's amendment concerning Suriname's independence. In the following days all remaining formalities were settled. By Kingdom law of 22 November 1975 the Charter came to an end for Suriname as of three days later, 25 November. Rather than the word 'Suriname' being removed from the Charter wherever it appeared, a final article was added to the document stating that as of that date the regulations of the Charter would no longer apply to Suriname - another sign of the haste with which the whole process had been conducted.

With that the Republic of Suriname had become reality. One of the final problems in the very night of 24 to 25 November had involved the national borders of the new Republic. Even though Suriname's borders had been in dispute since colonial times, in the end it was only established that they would remain as they had always been considered. The document drawn up in the early morning of 25 November only confirmed, rather vaguely, that both Suriname and the Netherlands declared to consider as territory of the independent state of Suriname, 'the area which up until the date of Suriname's independence was part of the Kingdom'. The issue of the disputed territories was not mentioned, let alone solved. The Dutch pledged future assistance should border conflicts arise, yet the document hints at research and possibly diplomatic support only, not at assistance in potential belligerence. ${ }^{44}$ Clearly there had been no attempt at reaching an agreement with Suriname's neighbouring countries, so that the new Republic inevitably inherited an awkward colonial problem, which raised its head once again with the recent border conflicts with Guyana.

A quarter of a century later, prominent figures still differ vastly in their appreciation of procedures followed during the hectic years of 1974-1975. The then Surinamese Minister of Interior Affairs Coen Ooft believes that 'quietly the Hindustani were only afraid that those who would receive independence (i.e. the Afro-Surinamese) would use this for the enlargement of their own political power'. In the same vein Iding Soemita, at the time a member of the Staten for the Javanese coalition party KTPI, recalls that 'Lachmon wished to remain under the supervision of the Dutch government because this would imply an element of protection'. The former Surinamese Prime Minister Jules Sedney is still in agreement with the fact that at the time no referendum was conducted on the question of whether or not Suriname should become independent: 'Neither do you ask a child whether it wants to become an adult. Arron deserves all the credit.' On the other hand, the then chairman of the Staten Emile Wijntuin now states that 'in hindsight I have to admit that the Arron administration dealt with this national issue in the wrong manner. It would have been wiser and more logical if the opposition had been included in the decision making process from the start.' 45

In hindsight it is particularly revealing that opinions on either side of 
the Atlantic regarding Suriname's independence appear to have changed so little. Jnan Adhin, at the time a prominent vHP member, recalled that 'the Netherlands wanted to get rid of Suriname as soon as possible. The Hague neglected its duties, it sent us into the desert. Maybe it can be seen as selfishness: the Netherlands being caught in the strong political thinking of that time.' Lachmon stated that 'taking such a decision with only a single seat majority in parliament was incorrect. And they should have granted my requests for the conducting of a referendum. I feel let down by Dutch politics and I have said so in parliament.'

Arron in contrast stated that 'what den Uyl was reproached for later on, namely that he just wanted to get shot of Suriname, I find clearly untrue. I think it was so important to den Uyl because of the Dutch fiasco in Indonesia. I am convinced that he believed that it would be better for Suriname if the country became independent.' Ferrier, Governor of Suriname at the time, is of the opinion that 'during the negotiations in 1974-1975, the Dutch government displayed the correct attitude towards Suriname. I believe that our future was dealt with in a careful manner.' Sedney admits that 'on the grounds of good governance the Netherlands could have intervened at the time. But obviously it was not prepared to pay that price for independence.' Wijntuin also believes that 'from the beginning, the Netherlands wanted to reach that independence. The Dutch government was of the opinion that Suriname was ready for that step. Mistakes were made in the preparation, which has been too emotionally driven and in actual fact also too opportunistic. I think that the Netherlands on the international scene could no longer account for its continued colonial bearing. ${ }^{36}$

At the proclamation of the Republic of Suriname on 25 November 1975, many solemn words were spoken. The parting Governor Ferrier, now the first President of the Republic, spoke of 'gratitude towards the countries within the Kingdom, the Netherlands and the Antilles, with appreciation and thankfulness'. Den Uyl, who in his speech took on his shoulders the guilt of centuries of colonialism and present-day disparities in prosperity, was visibly moved on the day. Once again he stated that the Netherlands 'when the Surinamese government declared to want to reach independence no later than at the end of 1975 , neither has been able, nor has wanted to do anything but give its full support. It has not been a painful process, but a creative activity, despite misunderstandings and sometimes harsh negotiations. 47

Looking back, the three key Dutch players - den Uyl, Pronk and de Gaay Fortman - strongly stressed the 'inevitable character' of the independence, which was after all hoped for by Suriname itself, the initial Dutch pressure exerted on the Arron government to proceed with caution, the still harmonious manner in which the transfer of sovereignty took place despite all the rush and tensions, and the 'price' of the negotiations, which was maybe higher than expected, but still acceptable. They indicated the Surinamese 
exodus towards the Netherlands and the differences of opinion concerning a Surinamese army as the largest drawbacks. But satisfaction predominated, especially with Pronk and den Uyl. In the self-congratulatory words of the latter: 'It was the first time in history that a formerly colonising country would help an ex-colony to stand on its own two feet in such a manner. This is the way it should be, but it is unique. ${ }^{48}$ And Pronk still believes 'that Suriname's independence process was historically inevitable. I have always agreed with den Uyl's view that it was rather too late than too early. Independence has never been imposed. 49

With the knowledge that we now possess some three decades later, more critical comments can be made. Was the Dutch 'cooperation' not all too eagerly conferred, with a blind eye towards the many pitfalls and towards the serious resistance within Surinamese society? There is every reason to answer this question in the affirmative. The political opposition was mainly regarded and treated as a party that needed to be convinced, or at least be persuaded by a generous Dutch policy in the field of development aid. Opposition from the rest of Surinamese society was not taken seriously. The Netherlands was not interested in gauging the opinions of the Surinamese through a plebiscite or new elections - clearly few illusions were held as to the 'negative' results of such consultations. The marked resistance of groups standing outside mainstream Surinamese politics were also ignored. Therefore, even today, the Surinamese Maroons fiercely criticise the events of 1975 and the transfer of sovereignty.

The whole procedure, which was far too short, between February 1974 and November 1975 had an exceptionally feverish character. One cannot but understand this as a seizing of the moment with the expectation that the potential of these years would probably not return - and thus conclude to a well-understood self-interest to not let this chance pass by. It is to be noted, however, that the decolonisation has taken place in a non-violent and, in the end, rather harmonious manner. This may indeed be seen as a fortunate outcome, in view of the potentially tense relations within Suriname. For the establishment of a united country, however, it would probably have been better if independence had been more struggled for, instead of having been granted so eagerly by the former coloniser. But the den Uyl administration can hardly be reproached for this.

In its preparation, development, and especially in its results, it really has not been the 'model decolonisation' that the Netherlands had hoped for. Den Uyl's pride in 'the manner in which the cabinet has guided the Surinamese independence process', even described by him as 'the finest hour' of his administration, seems rather dubious..$^{50}$ After all, Dutch policy was in the first place inspired by considerations of perceived self-interest. The Netherlands had disposed of Suriname, maybe with the best intentions, and also with generous concessions in terms of financial means and other privileges - like the migration regulations - but in the end still to make 
sure that a liability was finally removed from within the Kingdom's borders.

The question remains whether The Hague could have adopted a different attitude. Not only would a more cautious approach by the den Uyl administration have fallen on deaf ears among its own left-wing rank and file, but also, as it became clear from opinion polls, among the majority of the Dutch population. But there is more to it. One imagines the situation where The Hague at a certain moment had refused to further cooperate with the realisation of independence, or had wanted to reduce its pace. A delay would probably have led to cancellation; with new elections on the horizon in both countries, the present conducive atmosphere would at the very least have been jeopardised. A downright refusal to cooperate would have placed the Dutch cabinet in an impossible position. As Minister de Gaay Fortman stated two decades later: 'I do not see how we could have stopped the independence of Suriname. Yes, of course you can preach: I am sorry to have to say this, but you still have too little experience for independence. But you could not start on that. ${ }^{51}$ The Arron administration would without doubt, and not without reason, have denounced such a Dutch standpoint internationally and would also have organised protest in the Netherlands. However small the international response may have been, for the progressive country that the Netherlands prided itself to be, this possibility was a true nightmare.

In hindsight, Dutch criticism on the den Uyl administration abounds. Joop Bakker, an earlier Minister for Surinamese and Antillean Affairs remarks: 'I believe that independence has been forced upon Suriname. It was too much Joop den Uyl's thing: he considered the decolonisation of Indonesia a failure and now he had the chance to do things right. The consequences were really disastruous.' According to the top civil servant and advisor to Minister of Development Aid Pronk, Ferdinand van Dam, 'it was primarily an ideological matter to den Uyl and Pronk. Den Uyl found that a Labour Prime Minister could not be premier of a country in possession of colonies. It is a kind of guilt feeling combined with a sense of superiority. This was being compensated for by clasping them to their bosom.' According to Fons van der Stee, former Minister for Antillean Affairs, 'with den Uyl and Pronk it was seen as a crusade. We have kicked Suriname out of the Kingdom.'52

A quarter of a century later the Christian democrats Ruud Lubbers and van der Stee, both having served as Ministers under den Uyl, recalled that the policy for the transfer of sovereignty was indeed primarily designed by the social democratic Prime Minister and his Minister for Development Aid, Pronk, and to a far lesser extent by de Gaay Fortman, the confessional Minister for Surinamese and Antillean Affairs. Even if they perhaps sought to clear themselves of what was afterwards widely considered to be the fiasco of Suriname's independence, the archival records tend to corroborate 
their position. Den Uyl and Pronk had been decisive, had had a clear vision, and had been impatient to realise their plans. De Gaay Fortman, making earnest appeals for caution, had been hesitantly opposed to the forcing of independence upon Suriname. As Lubbers and van der Stee emphasised, he had easily been overpowered, unable to cope with the 'political force' of the two social democrats who eventually proved authoritative in this issue. Small wonder, this judgement is firmly contradicted by Pronk. ${ }^{53}$ Of course it is important to remember that political games are being played here and that in 1975 all Dutch political parties supported the transfer of sovereignty, and thus share a collective responsibility.

\section{The Antillean Refusal}

Five months after the Curaçao revolt of May 1969, Minister for Surinamese and Antillean Affairs, Bakker, in consultations with administrators from the Antilles had fiercely denied the suggestion that the Netherlands was taking economic advantage of the Caribbean. It had to be clear that 'from the Dutch side, millions of guilders are pumped into the Antilles and Suriname on a yearly basis, and that in this light it would be preferably today rather than tomorrow that the Netherlands would get rid of the Antilles and Suriname. ${ }^{54}$

Within Antillean politics there was an acute awareness of this fact. As a result, pragmatism made the option of political independence unpopular. In this respect the Antillean aims were diametrically opposed to the decolonisation policy that the den Uyl administration had made its norm. There was also another issue which divided the Antilles. Whilst the national government and administrators of five of the six islands, along with the Netherlands, wished to keep the Antilles united, Aruba's traditional strive for secession from the Antillean state had received a new impetus as a result of 30 May 1969 and the prospect of a possible future independence. As would become clear after 1975, this impetus proved decisive.

Backed by Governor Ben Leito, the Isa-Beaujon administration (19711973) and the Evertsz administration (1973-1977) repeatedly denounced independence in the near future. The Antilleans were fearful that the Netherlands was only interested in forwarding its own political agenda. Whereas politically den Uyl had found in Arron a kindred spirit, their Antillean counterpart Juancho Evertsz saw things differently. He would, with Governor Leito as an ally, succeed in resisting Dutch pressure. Even though lip service was paid to the principle of independence, Evertsz' stance gave evidence, above all, of the gentle pace with which the Antilles wanted to move, or pretend to do so, in the direction wished for by the Netherlands. This became clear with his list of conditions linked to the "methodical preparation for sovereignty', making independence a very distant goal in reality. The 
Antillean standpoint that 'direction and planning of the moment at which, and the circumstances under which sovereignty will begin, will be exclusively determined on the basis of the interests of the population of these islands ${ }^{355}$, was an implicit refusal to play along with the Dutch game. Instead, the Antillean cabinet under Evertsz limited itself to not obstructing Suriname's way, without following the same path itself.

Impatient Dutch members of parliament advised the den Uyl government to follow a harsher line. The social democrat Huub Franssen wrote to den Uyl, venting his irritation towards Antillean politicians: 'Grumbling about the Netherlands, internal bickering and badgering for more money. I am firmly convinced that all our friendliness of recent years has only spoiled the case. ${ }^{56}$ Den Uyl agreed. A delay in the transfer of sovereignty for a few more years was acceptable, if needed, but no longer. Moreover, the falling apart of the Antillean nation was deemed unacceptable, as den Uyl emphasised during his visit to the islands in August 1974. Willemstad, however, did not allow itself to be urged into sovereignty. At the beginning of 1975 Evertsz sent a letter outlining requirements for a possible independence to his Dutch colleague, which, due to the eventually positive answer, would have far-reaching consequences. Evertsz had stated that independence would be reached following the completion of three stages: first the realisation of internal self-government of all six islands, then a new cooperation between the islands, followed by stage three 'in which the preparation for independence will be finalised, although not before it is certain that the population of the islands at the start of sovereignty will have attained a reasonable level of economic development. ${ }^{37}$

Evertsz interpreted the promised Dutch cooperation to the 'methodical preparation for independence' as a token of the Dutch cabinet's 'patience'. His requirements for independence included socioeconomic, judicial and territorial conditions, along with geopolitical security. Evertsz requested aid to elaborate an 'integral socioeconomic plan', the elaboration of which made very clear that his vision was so ambitious that it surely could not be realised in the foreseeable future. With this, negotiations petered out. The 'Commission of Experts', drawn from various fields for the preparation of an integral socioeconomic policy plan, would not be established until November 1976 and reported no earlier than August 1979.

Today, Antilleans from various backgrounds take a remarkably unanimous positive stand with regard to Evertsz' attitude at the time: pragmatic, aware of the vulnerability of the Antilles, and thus averse to a swift independence, if at all. The later Aruban Prime Minister Henny Eman expressed himself in graphic terms: 'Fortunately, at the time the Netherlands Antilles and Aruba were wiser and have been obstructive. ${ }^{58}$ 


\section{The Perpetuation of the Transatlantic Kingdom since 1975}

Mid-term the den Uyl administration, in retrospect often characterised as 'the most progressive Dutch cabinet ever', succeeded in transferring sovereignty to Suriname. ${ }^{1}$ Closing the book on the Antilles was also a target, but in the later stages of this period Caribbean affairs were no longer a priority in The Hague. After its premature fall in 1977, the den Uyl cabinet left a legacy of political polarisation rarely seen in Dutch history. Despite a clear left-wing victory in the elections, a centre-right coalition won the day and, in fact, up until 1989 the Netherlands was almost continuously run by coalitions of Christian democrats and conservative liberals. Economically, this was a period of wavering growth and even years of recession. The answer in the domain of industrial relations was a substitution of polarisation for moderation and cooperation, thus laying the foundations for the rather spectacular economic growth of the 1990s. The same was true in the social and political arena, which also witnessed a turning away from polarisation during much of the 1980 .

When the social democrats returned to power in 1989, they had cast off most of the ideological legacy of the den Uyl years. During the 199os the social democrats governed in a period of economic buoyancy, being the second in command in a centre-left coalition under Ruud Lubbers' third term, and the largest partner in the following unique 'purple coalition' with conservative liberals under their own leader Wim Kok, who became Prime Minister. In 1994, for the first time ever, the formerly unassailable Christian democratic centre had been ousted. Yet as the economy grew, along with immigration - the Netherlands remaining one of the staunchest supporters of further European integration at the same time - an undercurrent of dissatisfaction grew. All traditional political parties seemed to be too alike. In the midst of economic prosperity, the quality of formerly outstanding services provided by the state in the fields of education, public health and transport increasingly declined. The immigrant population grew at an unprecedented rate, yet politicians were found to be either unwilling or incompetent to address the related social problems and challenges head on. In fact, it seems that Dutch society ánd politics were heading towards a more pragmatic and even cold approach on issues such as immigration, international aid and trade.

In this context, the first elections of the new millennium produced a landslide of even larger dimensions than in the 'revolutionary' mid-197os. The populist party LPF named after its charismatic leader Pim Fortuyn de- 
veloped rapidly in the presence of an uninspiring sitting coalition. Unprecedented in modern history, a political murder ended the life of this leader a week prior to the May 2002 elections. This, if anything, only helped his party to a landmark victory alongside the reborn Christian democrats. Hence, early in the twenty-first century, the Netherlands had voted another 'radical' cabinet into power, this time right-wing in nature, a good quarter of a century after 'the most progressive cabinet ever'. Within three months - another rupture with Dutch political tradition - this right-wing cabinet under the Christian democrat Prime Minister Jan Peter Balkenende collapsed, mainly because of continuous bickering within the decapitated LPF. New elections resulted in the demise of the LPF and a spectacular recovery for the PvdA. Even so, yet another centre-right coalition was formed.

The question is to what extent all of this affected Dutch Caribbean policies. In reality it had little effect. Historically, political leanings of parties either left or right had scank impact on the direction of policy. The leftist program of 'full decolonisation' was taken on board by the centre-right coalitions all through the late 1970 os and 1980s. In reverse, during the $1990 \mathrm{~s}$ all political parties agreed to the perpetuation of the transatlantic Kingdom. Yet, as the decade progressed, frustrations arose regarding perceived Caribbean failures and in particular the Curaçaoan exodus, and the tone towards the Antilles and Aruba became more blunt. Again, political affiliation mattered little in this respect - at least until 2002.

What preceded all of this? The course of history in this third period, covering the final quarter of the twentieth century and the beginning of the twenty-first, provides scope for remarkable conclusions. Considering the prevailing Dutch attitude in the 1970 and 1980s, decolonisation should long since have been a closed chapter. During the 1980 s, or at the very latest the beginning of the 1990s, the Netherlands Antilles should, after all, also have accepted independence. In this scenario Suriname's independence in 1975 would have been no more than the penultimate step; the transfer of sovereignty to the Antilles would have constituted the finale. With this, the Kingdom of the Netherlands would have been contracted once and for all and returned to its original habitat on the shores of the North Sea.

Clearly things have not turned out this way. Not only the North Sea but also the Caribbean sea still laps against the long coastlines of the Kingdom, and there is every indication that this will be the case for the foreseeable future. In this chapter this paradoxical history will be described. Paradoxical in its course, which has largely become 'decolonisation upside-down', with the (former) colony resisting 'complete' decolonisation and the mother country in pursuit of this goal. Paradoxical in its outcome, which lies closer to the wishes of the former colony than to the aims of the post-colonial power. The paradox continues when we see that the Charter, still the legal basis of the transatlantic Kingdom, is once again under severe criticism, this time because of the rigidity of the document. 'Not an eternal pact', as 
the Charter was appraised at the time. In the last quarter of the twentieth century this characterisation became a caricature of itself. The Netherlands finds itself reluctantly bound by this rigid document of its own making.

In the course of the 1980 s political thinking shifted and by 1990 Dutch policy would take a U-turn, as it became generally accepted that the decolonisation process would not be completed in the classical sense of a transfer of sovereignty. The domain in which politicians and administrators on both sides of the ocean came together was redefined once again. Rather than the debate centering on the question of whether or not the Charter would continue to exist, the question now related to its scope particularly the relationship between national and island autonomy on the one hand and the responsibility of the Kingdom government on the other. This would become an increasingly heated issue on the political agenda and continues to be the crucial issue into the twenty-first century.

During the 1970s and 1980s the Netherlands had not only taken the stand of requiring the Antilles to accept independence in the short term, but also that this should be accomplished as a united country of six islands. Only under those circumstances would the new state be viable in the eyes of The Hague. This objective of unity also appeared to be an illusion. In 1983 both the Dutch and the Antillean governments agreed to Aruba opting out of the Antillean state. The Dutch objective then was to ensure that this status aparte, which came into effect in 1986, would be followed by a full transfer of sovereignty to the island ten years later. Again, history would take a different course. In 1996 Aruba obtained a permanent status as a country in its own right within the Kingdom, alongside the Netherlands and the Netherlands Antilles. Within the present construction of the 'Antilles-offive' centrifugal tendencies still have not been curbed. During the 199os, tensions between the national government and the islands, arising from decades of disagreement and dispute, would foster increased Dutch attention, even if these tensions were in the first place an 'internal' Antillean affair.

In the meantime the Netherlands would become increasingly involved in the economic and administrative development of the Antillean state. Apart from the care of good governance, this mainly concerned the 'mutual assistance' as stated in the Charter, for all practical purposes, simply Dutch. The effects of this involvement were dubious. The severe crisis in the Antillean administration, economics and indeed society was at the end of the twentieth century a cause for great concern in The Hague, polarised by a new Caribbean exodus, this time from Curaçao.

This third period has been rather non-eventful when compared with the two former periods (1940-1954 and 1954-1975). The Charter still stood, the most important mechanisms of cooperation and consultation remained unaltered. The transfer of sovereignty to the Antilles, the 'radical' change strived for by the Netherlands, was not realised. The recognition by the 
Dutch that these intentions were no longer realistic, along with the legitimised Aruban secession, were the fundamental new political developments and, in themselves, led to an unprecedented Dutch involvement in the sphere of good governance on the islands.

Institutionally, there have been some significant changes in the Kingdom relations. As of 1975 the transatlantic Kingdom consisted of only two countries, while in 1986 Aruba became a separate nation and thus an individual Kingdom partner. This would seat another plenipotentiary minister in The Hague, as well as a Governor on Aruba. Both the minister of Antillean Affairs and the bureaucratic cabinet in charge (KabNA) added 'and Aruban' to their title. The KabNA office in Curaçao, established in 1970 and upgraded in 1975, was in 1986 complemented with an office in Aruba. Soon after, a third office was established in St. Martin in the early 1990 .

Of the seven ministers responsible for Dutch Caribbean affairs from 1975 up until 1998, only one was a social democrat, and served less than a year. The others were either Christian democrats or conservative liberals. As will become clear, there is little indication that their political affiliation made much of a difference in this sphere. All had their major tasks in other departments, including Justice, Social Affairs and Defence.

Like the minister it served, KabNA itself remained itinerant and therefore vulnerable within the Dutch civil service. Partly as a consequence of the realisation that the transatlantic Kingdom would remain intact for some time to come, a more solid bureaucratic foundation was required. Thus KabNA, an increasingly criticised body, was liquidated in 1998. It is telling that its functions were taken over by the Ministry of the Interior, which was generously renamed 'Ministry of the Interior and Kingdom Relations'. From 1998 to 2002 Caribbean affairs were managed by a state secretary, although ultimate responsibility lay with the minister of the Interior and Kingdom Relations. For the position of state secretary a conservative liberal was appointed once more. The coordinating minister of the Interior and Kingdom Relations however, was a social democrat - again, this political difference was of little significance.

\section{The Aruban Status Aparte}

The striving of Aruba for separashon originated in the 1930s, but would only gain its decisive momentum in the 1970s. During the 1930s, the grand man of Aruban separatism was Henny Eman sr, who would pass the baton to his son, Shon A. Eman, who in turn would be succeeded by his son Henny Eman jr - since the 1970 leader of the Arubaanse Volkspartij (AVP) that endeavoured to achieve a separate status for the island as a country within the Kingdom, rather than full independence. Henny Eman would become Aruba's Prime Minister during the first years after the coming into being of the 
status aparte (1986-1989) and again would lead the country between 1994 and 2001.

However, the party that dominated the political scene during the 1970 s and 1980 s was Betico Croes' Movemiento Electoral di Pueblo(MEP). In 1971 this party broke away from the AVP and succeeded in amassing a large following. Like the AVP, the MEP aimed for Aruba's secession from Curaçao rather than from the Netherlands. Yet unlike the AVP the MEP would, in the process, also consider the possibility of full Aruban independence; at least not excluding this option as the price to be paid for separation from the Antillean state. The thought of continuing as one of the six islands under an independent Antillean government was considered abhorrent. Up until 1986 the MEP was the largest Aruban party, and was therefore the mouthpiece for Aruba in dealings with the Antilleans and the Dutch - as a result Aruban separatism was often associated in The Hague with 'Betico' and his MEP.

Much to the regret of The Hague, its post-1969 policies would only add impetus to the Aruban separatist movement. The revolt on Curaçao served to deepen Aruban suspicions towards the larger island. The political elites of Aruba had always tended to emphasise the Euro-Amerindian roots of their island as opposed to the African character of Curaçao. The revolt of May 1969 now added to the suspicion, as this seemed to be centred around 'black power' issues. When the Dutch reacted by making the transfer of sovereignty their priority, Aruban politicians were quick to respond. If anything, they would rather become a country in their own right than an island within an independent state dominated by Curaçao.

At the end of 1975 the relative peace on the Antillean political front was broken. Without the knowledge of the central government in Willemstad, a delegation of the MEP paid a 'good will visit' to Venezuela in order to gauge feeling regarding the secession or independence of Aruba. Even though on earlier occasions the Antillean Staten had openly and formally agreed that Aruba was allowed to determine its own future status ${ }^{2}$, this unexpected escapade led to a crisis within the Antillean government. For Prime Minister Juancho Evertsz a continuation of the federation of six was clearly the only possibility. Borrowing from Eric Williams' famous dictum on the West Indian Federation ('ten minus one equals nil'), Evertsz constantly warned that one out of six would leave nil, a conviction to which he still adheres. 'The Netherlands has absolutely made a mistake when it separated Aruba from the Antilles. With 80,00o people, Aruba cannot exist as an autonomous country. And the Antilles-of-five is an impossibility. I still cannot understand this incorrect Dutch decision.'3

In the - vain - hope that he could gain international support and recognition for his plans, Betico Croes not only made a tour in the region in the course of 1976 and 1977, but he also visited the United Nations Decolonisation Commission and the U.s. State Department. The Dutch still stood 
firm. Reluctantly, in February 1976 the Dutch government did receive an Aruban delegation, but Minister for Antillean Affairs 'Gaius' de Gaay Fortman would only listen to the wishes expressed and would not be engaged in discussion. In short, he characterised an independent Aruba as 'no profitable affair' and, if the island was to gain sovereignty, the Netherlands would not designate part of the Antillean development aid to Aruba. Croes described this attitude as 'blackmail politics'. After the meeting de Gaay Fortman informed Premier Evertsz: 'My impression is that the reception of the delegation in the Netherlands was regarded as disappointing. The situation remains serious, but I suspect that in the forthcoming time they will surely go no further than making threats and applying pressure.'4

Undoubtedly, this dismissive attitude has played a role in the decision of the MEP dominated Aruban island council to gauge reaction to the idea of independence in an opinion poll. On 25 March 1977 a consultative referendum was held on Aruba, with only two options. The first was an independent federal Antillean state, of which Aruba would be part, and the second an independent Aruba. The referendum did not include the option of a separate status for Aruba within the Kingdom, as this had been consistently rejected by The Hague. Since this third option was excluded the AvP boycotted the referendum, which made the outcome even more controversial. A large majority of the electorate, 82 per cent, was in favour of the second option, which amounted to more than half of the registered voters ( 70 per cent of the electorate had voted). Only 4 per cent had chosen the first option. However, since a rejection of the Antillean state could only manifest itself in a pro-independence vote, it is doubtful whether the Arubans in fact preferred independence for their island. Afterwards the outcome has mostly been interpreted as a choice for 'sovereignty' within the Kingdom, separate from Curaçao. Even though the other parties cast doubts on the outcome, Croes' MEP interpreted it as support for its intentions.

In the summer of 1977 an explosive situation arose in Oranjestad, Aruba's capital. Bottled up tensions found their release in strike actions prompting interest from the international press. A Venezuelan newspaper reported that the Netherlands was carrying out colonial policy. The August riots would prove to be a turning point. The Hague, concerned about 'the image that the world perceives of the problems on the Antilles', became convinced of the seriousness of Aruba's wishes to follow its own path. The political progress of the dominant MEP, under Betico Croes' charismatic leadership, was viewed as deadly serious. Minister de Gaay Fortman was informed that 'the centrifugal tendencies have gained momentum and this development can no longer be stopped'. 5 A cooling down period was established, during which a speedy revision of the mutual island relations could be worked on.

On 4 September 1977 a thirteen-strong Aruban delegation arrived in the Netherlands. Betico Croes immediately declared that if The Hague would 
not lend an ear to their wishes, Aruba would openly bring charges against the Netherlands for 'treading on human rights. If we return home emptyhanded we may unilaterally proclaim independence. ${ }^{6}$ Indeed, for the first time in history an Aruban delegation truly found response in The Hague, which in itself was a breakthrough. The wish to separate from the other islands - preferably no later than 1981 - was discussed in depth over four days. The pressure subsided, even though the delegation could not return home with tangible results. On the contrary, the lengthy discussions had made one thing very clear; according to the Dutch Council of Ministers an independent Aruba was inconceivable, and fragmentation of the Antilles could prove fatal. Yet with the Dutch promise that the cabinet would soon convene a meeting on the subject in the Antilles, an opening had been forced in the stalemate.

Similarly, with the coming into office of the new Minister for Antillean Affairs Fons van der Stee, a wind of change would pervade the Kingdom relations. Even if van der Stee was not at all a believer in micro-states, he did not - like his predecessors - dispose of the Aruban problem as an internal affair of the Antilles. Henceforth the Aruban aspirations were to be discussed at Kingdom level. In this way, slowly but surely Aruba was taken seriously in its bid to be released from the authority of Curaçao. This process, however, did not only revolve around Betico Croes or the MEP. Decades later, van der Stee still recounted the 'exceptional hostility' between Aruba and Curaçao. 'We hoped to channel this. But from a certain moment you cannot stop it. The aversion was so deep. It had not begun with Betico Croes.7

As promised, van der Stee came to the Antilles in April 1978 for a meeting with Antillean and Aruban delegates. According to him, this event confirmed the 'evolution in the political thinking of the Dutch government'. Now 'the time was ripe for an open discussion on a revision of the current relations within the Kingdom'. ${ }^{8}$ A study group would be established to advise on the relations between the Antillean state, the six islands and the Netherlands; included would be the Aruban wish for independence and all possibilities were to be investigated.

With the mutual agreement, laid down in the 'Protocol of Willemstad' of 20 April 1978, van der Stee succeeded in improving the disturbed relations between the Antillean government and Aruba in such a way that the groundwork for further consultations was laid. For the first time in history the Aruban aims had been openly discussed among all parties directly concerned. In December 1978 the 'Kingdom Study Group' for the investigation and development of a possible new political structure for the Antilles was established, with representatives not only from the Antillean and Dutch governments, but also from all six islands. No forced independence, not even a term for the independence of the six islands altogether, and no exclusion of the possibility of a separate Aruban independence, these were 
the corks on which the study group would float. In the House of Commons van der Stee clarified this rather cautious approach: 'The preparation for the independence of the Antilles will demand more time, care and study than we previously believed. This is the lesson we have learned from Suriname. At that time we did our utmost and I have the idea that we delivered a clever piece of work. However, one always learns from one's mistakes. I believe that we do not need to make the same mistakes again if we take a little more space in time.' ${ }^{9}$

In August 1980, after eighteen months of strenuous proceedings - the minutes of the consecutive meetings reveal a dedicated Aruban delegation having to deal with rather uncooperative Curaçaoan representatives - the study group established that 'the conception of the six islands forming the Netherlands Antilles is a legal construction that has every resemblance to fiction. ${ }^{10}$ One of the few aspects on which consensus had been reached was the belief that, regardless of the 'end situation', a rather long transitional period would be needed before it would be possible to establish new relations. Similarly, almost unanimously, the Kingdom study group had reached the conclusion that it would not be necessary to amend the Charter during this transitional period.

Only Avp leader Henny Eman, averse to any option other than a permanent separate status for Aruba within the Kingdom, thought differently. According to him it was essential that during a transitional period of unlimited duration the island would be given a status aparte. Thus, instead of the bonds with the Netherlands becoming looser in this phase, they would only be tightened. Furthermore, according to the AvP, at the end of the transitional phase the Aruban people should be given the opportunity to decide via a referendum on the final status of their island. In the press Eman declared that the work of the Kingdom study group equated to 'playacting', an opinion that he reiterated recently: 'That study group was like a stage-play. It was then that the MEP took independence on board because the Netherlands was saying: "If you want status aparte, then you will have to become independent." Even the MEP, so Eman states, had little desire for independence; the party was forced into it. 'The Hague was using it as a means to keep Aruba within the Antilles. In any case I did not believe in that sanction on the status aparte. ${ }^{11}$ Eman's wishes provoked great concern within the Dutch delegation. Aruba as a separate country within the Kingdom was viewed as a step backwards rather than forwards on the path to an integral Antillean independence. Yet Eman's strategy would eventually triumph.

In February 1981 the round-table conference that followed the study group's report would yield few results. Following a week in which the Caribbean parties only showed disdain for one another, consensus had only been reached on the principle of a gradual and methodical transitional period of decentralisation and political restructuring. Desperation was taking 
hold of the Dutch. 'This is leading to nothing', Minister van der Stee exclaimed, 'a formula should be conceivable with a bit of good will, if one is prepared to reach a conclusion. In my life I have attended many conferences, but never one like this. ${ }^{12}$ Except for the formal recognition of each island's right to self-determination - in itself a crucial breakthrough - the talks would end without any form of political agreement. The Curaçaoan delegation had been unresponsive; Betico Croes had held his ground stating that in 1991 at the latest Aruba should become independent; Eman's AVP had persevered in its rejection of full independence. The Netherlands had only agreed to a 'rather long' transitional period during which Aruba was not allowed to leave the Antillean state - separate links between Aruba and The Hague had remained beyond discussion.

During the following months the controversy between Aruba and the central administration on Curaçao intensified, with Dutch patience running out. The desired option as envisaged both by The Hague and Willemstad remained the continuation of the 'Antilles-of-six'. After all the Antilles were not 'just a legal fiction', as the Antillean Prime Minister Don Martina emphasised: 'For decades we have cooperated with each other and achieved many good things. ${ }^{13}$ According to the Antillean government, Aruba would indeed have to resort to independence if the island refused to follow this first option, and in that case sooner rather than later so as not to hold up the necessary restructuring of relations between the remaining five islands.

However, The Hague was no longer citing the blame for the unworkable situation solely on 'the troublesome' Aruba. A fortnight after the installation of the second cabinet under van Agt, in September 1981, the new Minister for Antillean Affairs, former Prime Minister Joop den Uyl, arrived in the Antilles. The new Aruban position, that it was unacceptable to wait another ten years for independence, would now see the Dutch abandoning their intended policy and relenting to Aruban wishes. Den Uyl moved to a position of confronting Aruba with the 'harsh consequences' of independence: 'It is not possible to once again apply first-aid, the process cannot be left floating', so den Uyl stated. Aruba agreed to opt for an 'orderly and methodical preparation of its independence. ${ }^{14}$ It was decided that a tripartite study group would map what consequences the granting of sovereignty to Aruba could have for the island itself, for the central government of the Antilles, for the other islands and for the relations with the Netherlands - the latter only willing to maintain ties on the condition that Aruba would at least cooperate with the other islands within a solid and durable framework.

On 25 November 1982, ten months after its installation, the 'Combined Commission on the Future of the Antilles' would issue its report. The core proposals revolved around the recommendation of a transitional phase towards Aruban independence of no longer than ten years. During this phase Aruba could enjoy a separate status as a country within the Kingdom with a precondition that the island should form a 'Union' with the remaining five 
islands. Within this Union, communal tasks in the fields of legislation, education, jurisdiction, commerce and monetary affairs would be regulated.

With the new cabinet under Lubbers (1982-1986) accepting these proposals, the prospects for the original Dutch policy of the six islands gaining independence as a unitary state had all but evaporated. Furthermore, the Dutch had given in to Aruba's wish for a status aparte, albeit for only ten years. Yet to curb further separatist tendencies, the Dutch line of 'separate status, then also independence', was firmly held on to. To a great extent the Dutch insistence that as part of the deal Aruba would leave the Kingdom within a fixed-term, was aimed at deterring other islands from following the same path, in particular Curaçao and St. Martin. The Hague nurtured a deep felt apprehension of an outcome where all six islands would enjoy separate relationships with the Netherlands.

It was time to get down to brass tacks. In March 1983 chairman Lubbers opened a new round-table conference of the Kingdom. Prime Minister Don Martina expressed his optimism at the possibility of finding definitive solutions to the long-running differences of opinion between the central government and Aruba. Willemstad would support Aruban aspirations. Betico Croes, leader of the Aruban delegation, called this first meeting a memorable event: 'In the year 1983 we again discuss a holy wish. ${ }^{\text {'15 }}$ From the opening words of the new Minister for Antillean Affairs Jan de Koning it became clear that the exercising of Aruba's right to self-determination irrevocably had to end in independence. He also made sure that no one would doubt that the intended 'solid and sustainable cooperation between Aruba and the Antilles', in the form of a Union, was a price to be paid by Aruba in order to obtain the desired secession. If this condition was not met, then Aruba would have to become independent within four years.

The transfer of sovereignty to the other islands was not on the agenda, although the Dutch delegation made it clear that independence was still the target for the remaining 'Antilles-of-five'. After the conference the Netherlands would therefore open discussions on the preparation of a 'fundamental revision' of existing relations. The Dutch were hoping that this awareness would increase the inclination of the islands to establish a cooperation as solid and durable as possible with Aruba. The five islands, however, merely stated that independence was not their goal.

Again, this conference would be dominated by differences of opinion on the one hand between the Antilles and Aruba on the strength of the cooperation structure, on the other hand between Aruba and the Netherlands on the inevitable consequence of independence coupled to the starting date of the status aparte. With the exception of the AVP, the Aruban delegation did abide by the Dutch requirement of a maximum of ten years before the transfer of sovereignty, but it resisted fixing the precise starting date of independence in the Charter. According to the delegation it would be more suitable to take supplementary decisions regarding Aruba's independence 
at an appropriate juncture. Since the Aruban delegation insisted on including in the Charter a future 'evaluating conference', its scepticism regarding full sovereignty became blatantly obvious. Meanwhile, the question as to the shape of the future relations of an independent Aruba with the Netherlands was left largely unanswered. Albeit with reservation, The Hague expressed its willingness to cooperate in a 'Commonwealth sui generis'.

With emotions running high, the debates made slow progress. As only two days remained, chairman Lubbers decided to speed things up. He made it very clear: 'Somewhere we have to draw the line. If tomorrow you cannot summon the courage to take responsibility and set out the beacons towards a new relationship, then in my opinion we had better forget about the entire adventure.' During the night, Lubbers, together with his advisor and general secretary Joop Merckelbach, would draught a 'definitive document' to which he required a 'go' or a 'no go' the following morning, on the final day of the conference. ${ }^{16}$

However, as difficult points had not been cleared this document was not favourably received either. Not only was Aruba compelled to make use of its right to self-determination under conditions set by the Netherlands - Aruba had to start the status aparte as of 1 January 1986 and therefore 'opt' for independence as of 1 January 1996 - but also the phase of the status aparte needed to be accompanied by a strong Union with the other islands. These Dutch preconditions went down badly, with an angry Betico Croes responding: 'We find that - when the fate of our people is being decided your tactics at the close of this conference are reprehensible. At this moment we believe that you are using the weight of the mother country's position of power within the Kingdom to your advantage. ${ }^{17}$ With the Dutch delegation refusing to give way, the conference threatened to reach deadlock. Grudgingly, Croes eventually relented and on behalf of the delegation agreed to the condition that Aruba would indeed become independent in 1996. With the exception of the oppositional AvP, which made sure to include in the minutes its usual footnote that independence should not come about without at least a preceding referendum, all delegations accepted the document. Thus the conference ended with concrete results.

With this, after many years, Betico Croes had won the struggle and could carry off the separashon; Aruba would become a Kingdom partner with all the ensuing rights and obligations as of 1 January 1986. The Dutch, in turn, had imposed independence as the non-negotiable price. So there seemed to be a reward for The Hague as well. It was still hoped that with Aruba, the Antilles would also leave the Kingdom by 1 January 1996.

In hindsight Nel Oduber, presently MEP leader and Prime Minister of Aruba, confirmed Eman's view that the MEP did not really strive for independence. 'In all honesty: at the time we used the right to self-determination from a strategical point of view rather than truly wanting to become independent of the Netherlands. The conditional sale of status aparte - in- 
dependence was the consequence of both Curaçao and the Netherlands wanting it that way.' This view is supported by Miguel Pourier, former Prime Minister of the Antilles: 'Everybody knew that Betico was not looking for independence. It was purely a strategy to dislodge the island from Curaçao. He played his hand very well. ${ }^{318}$

The core to the status aparte was that, as of 1986, Aruba would be able to manage most of its domestic affairs. However, partly as a result of the difficult economic situation on the island during the mid-1980s, the decisions of the 1983 conference only found slow implementation. The oil sector, long the backbone of the island economy along with the offshore financial industry, was confronted with great difficulties. Tourism and the service industries had also suffered greatly due to the crisis in Venezuela. Furthermore, both the Antilles and Aruba were reluctant to transfer a large part of their internal autonomy to the intended Union, as requested by the Dutch. The islands instead opted for a 'Cooperation Regulation' of a less restrictive character, not even coming close to the 'solid and durable structure' originally envisaged. Despite Dutch pressure, even this low-key AntilleanAruban cooperation would not fully materialise until the mid-1990s, when both countries were able to make a truly new start. 'Although confrontation has always characterised the relations between our countries, the era of cooperation has arrived', so an optimistic Prime Minister Eman stated in 1995 after having reached an agreement with his Antillean colleague Pourier. ${ }^{19}$

The 'solidarity fund', one of the relating arrangements made during the round-table conference, also featured prominently in the discussions after 1983. This was primarily driven by the Dutch desire to smooth the financial consequences of Aruba's secession. The larger islands, including Aruba, would support the smaller ones under this provision. But long-running bickering would ensue, with the islands strongly protesting against the Netherlands only intending that a contribution be made in dribs and drabs, which eventually ended in a preliminary regulation so as not to endanger the feasibility of the status aparte. Even to this day the intended Kingdom law regarding the solidarity fund has not seen the light of day.

The final thorny problem in need of resolve and remaining equally high on the political agenda up until the present day concerns the political consequences of Aruba's separate status for the remaining five islands. Due to this secession a restructuring of the Antilles-of-five became necessary. Yet despite numerous official and political reports, virtually nothing has changed and the relations between country and islands remains problematic. Inevitably, Curaçao became even more dominant within the Antillesof-five than it used to be within the Antilles-of-six. Similarly, the island of St. Martin would first demand more influence within the central administration and at a later stage start its quest to achieve its own status aparte.

During the implementation of decisions made at the conference of 1983 , 
it often appeared likely that the status aparte would not be reached by 1 January 1986. On top of the stagnation in the political decision making, in October 1984 it was announced that the Aruban Lago oil refinery was closing. Aruba was at risk of accepting its status aparte under a very unlucky star. The position of Venezuela was another factor provoking insecurity. Government advisor Merckelbach reported that the possibility of a close Aruban association with Venezuela was not only suggested on the island, but also by ministers in Caracas.

Besides the many mediatory efforts undertaken by The Hague in order to keep the decision making process in the Antilles up tempo, early in 1985 the bill for the amendment of the Charter was finished, and in the summer of that year accepted by the House of Commons and the Senate. With this, Aruba received country status within the Kingdom as of 1 January 1986, explicitly defined as a ten-year-long transition period towards independence. Henceforward the Aruban island council would become the Staten of Aruba. Indeed, on 22 November 1985 for the first time in history the Aruban people chose their own parliament. Remarkably, the MEP, the party that under the leadership of Betico Croes had waged the fierce battle for secession, even at the cost of accepting independence, suffered a defeat. The first Aruban cabinet was headed by Prime Minister Henny Eman; his Avp, that had always believed in a permanent status aparte, occupied four ministerial posts. The MEP was banished to the opposition. The blow was heavy, certainly for 'el libertador' himself. On New Years Eve, a few hours before the commencement of the status aparte, Betico Croes was killed in a car accident, driving into a telegraph pole on a lonely road. Many people saw - and still see - this as a conscious decision, but this remains unknown.

Dutch policy towards Aruba remained targeted at the impending independence, even if Eman and his cabinet did all they could to rid themselves of the agreement reached by arch-enemy the MEP. Eman held on to his conviction that the Netherlands did not have the instruments or the right to force Aruba into independence. The Dutch willingness to enter into a 'special cooperative relationship under international law' did not make a deep impression. When in 1988 Minister for Antillean and Aruban Affairs de Koning requested the Aruban cabinet to speak out regarding the form of relations with the Netherlands after 1996, Eman simply refused to give any statement on the subject 'already in the third year of the ten year long status aparte'. The AVP would persevere in its evasive attitude. Former Plenipotentiary Minister Mito Croes, since the 1970 s one of the party's prominent members, confirms that the Avp never intended to accept independence. ${ }^{20}$

Things were quiet until a new government was formed in 1989, this time under MEP leader Nel Oduber. Soon afterwards he travelled to the Netherlands in order to discuss independence. The talks revealed that his cabinet too nurtured certain desires conflicting with the status of an independent country. It became apparent that the MEP aimed at a future commonwealth 
relationship that in fact deviated only little from the existing framework of the Charter. Reluctantly the Dutch government began to face up to the fact that most of the decisions of the round-table conference of 1983 could only be realised within a permanent constitutional relationship and that Aruba's independence would not become a reality. The final chapter - this realisation - would be written under de Koning's successor, Minister for Antillean and Aruban Affairs Ernst Hirsch Ballin (1989-1994). Six minus one would not equate nil, but two, Aruba and the Antilles.

On the islands de Koning is remembered with laudatory characterisations: amiable, accommodating, a strong, generous minister. Yet one cannot escape the conclusion that the praise was not solely due to de Koning's personality and performance, but also to the relatively few moments of discord within the transatlantic Kingdom during his time in office (19821989). The one potential point of contention, independence, was never seriously pushed for by this Christian democrat who was well aware of the problems of independence in Suriname, from where his wife hailed. He was financially generous in his dealings with the islands. And there was never any question of an interventionist approach. In that sense, de Koning personified the end of an era.

\section{A New Dutch Agenda for the 1990 s}

During the late 1980 it became generally recognised in The Hague that the transfer of sovereignty to the remaining Caribbean territories, anticipated for so long, was a mission impossible. Along with the worrisome developments within the Republic of Suriname - a military coup in 1980 was followed by political murders, internal warfare as well as rampant corruption, burgeoning drug trafficking and economic crisis - the consistent Antillean and Aruban resistance had contributed to this realisation. In an internal memorandum by the Cabinet for Antillean and Aruban Affairs of December 1987 it was clearly stated that even if independence was still the Dutch objective, at best this had now become an objective 'for the (very) long term'. It was noted that the Antillean and Aruban people had no desire for independence, that the Netherlands hoped to avoid a repeat of the Surinamese drama and that, furthermore, on the international stage 'independence is no longer seen as something perfectly self-evident, especially not for microstates.. ${ }^{21}$

During Lubbers' third term in office (1989-1994) this awareness was reflected in a reversal of the professed policy line. The 1990s thus became a decade of revaluation and continuation of transatlantic Kingdom relations. Within this new context it soon became clear that relations would remain problematic. Figuring more prominently on the agenda than ever before were arguments regarding centrifugal tendencies, good governance, 
financial crisis and migration, along with questions pertaining to the deeper meaning and reformulation of relations within the 'newly styled' Kingdom.

In this context, all attempts to transfer sovereignty were gradually shelved. The appointment of Minister of Justice Hirsch Ballin as the government member responsible for Antillean and Aruban Affairs revealed that Lubbers in his third term in fact supported a drastic change in policy. Shortly before his ministership, professor of Constitutional Law Hirsch Ballin had written that, in his opinion, the Netherlands had better respect the Antillean and Aruban choice for a continuation of Kingdom relations; besides this he had not excluded the possibility of dividing the Antilles in two, a Leeward and a Windward country. It soon became evident that the incoming cabinet would indeed follow this new line.

The almost unanimous support in parliament for this change of course, just as former policies had always been able to count on large majorities, is once again illustrative of how little contention exists within Dutch politics on the subject. Yet it was probably no coincidence that after two centreright cabinets, it was Lubbers' centre-left cabinet that was responsible for this alteration of the course. When, during the 1980s, a widely felt scepticism regarding a possible independence for the Antilles arose, particularly the left-wing parties - formerly the avowed advocates of independence had openly retraced their steps. Now that they had once again returned to power, their active support for the policy of Hirsch Ballin was a matter of course.

The alarming developments within the Republic of Suriname and the ensuing strained relationships with the Netherlands also contributed to the revision of policies regarding the Antilles and Aruba. Major doubts as to the procedures and justification of the 1975 transfer of sovereignty to Suriname became widespread, also within cabinet. These doubts gave rise to plans by several members of cabinet to offer Suriname a degree of reintegration, or at least a very strong connection with the Kingdom, within the framework of a 'Commonwealth'. Although these plans were eventually nipped in the bud, from 1991 to 1993 a possible intensification in relations with Suriname was regularly discussed within the Council of Ministers. While the possibility of a renewed constitutional relationship ultimately failed to find sufficient support, with the 'Protocol of Bonaire' (November 1991) and the 'Frame Treaty for Friendship and Closer Cooperation' concluded in June 1992, conditions were created for an intensification of the cooperation that under international law was potentially unique.

Meanwhile, in March 1990, Hirsch Ballin had presented his 'Sketch for a Commonwealth Constitution for the Kingdom of the Netherlands'. Policy goals drafted within this programme corresponded to the ideas he had mooted previously. Under the intended Commonwealth Constitution Aruba was able to back out of the earlier independence agreement, and two 
new Kingdom countries would come about, Curaçao and Bonaire on the one hand, the three Windward islands on the other. In the Antilles, despite relief over the shelving of the independence issue, Hirsch Ballin's plans were received with mixed feelings - the criticism was aimed in particular at the intended split of the Antillean state. It is most likely that Antillean politicians were also alarmed by the professorial and assertive style of the new minister. In January 1991, after a meeting of members of parliament of the three countries, the Antillean delegation stated: 'The Sketch came too early and dictates too much a certain model. ${ }^{\text {,2 }}$

An agreement on Aruba's future was reached in July 1990. The Dutch and Antillean governments agreed that article 62 of the Charter, laid down in 1985 and stating the requirement of Aruba to become independent by 1 January 1996, would be deleted. Between the three Kingdom countries a new legal order would be realised. Discussions on an official and governmental level had yet to result in a workable model.

Besides this, in the government declaration of November 1989, Lubbers had stated the intention of his cabinet 'to investigate as to how far the regulations of the Charter, which were defined in the beginning of the 1950s, should be adapted to the requirements of this time'. Hirsch Ballin affirmed that 'there are good arguments to proceed with an integral rephrasing of the Charter'. A first step to this end was taken with tripartite consultations held in The Hague in May 1991. On this occasion the three countries once again confirmed their wish to continue the constitutional ties of the Kingdom. Incited by the Netherlands, they also decided that a communal study group would make proposals to 'simplify and modernise' the Charter. This would not only concern an editorial amendment, since 'in particular' it had to be investigated 'in which manner democratic and constitutional guarantees can be more emphasised within the new framework'. Accordingly a nine-strong 'Combined Study Group on the Modernisation of the Charter' was established and a report was expected within eight months.

However, things would work out differently. Not until June 1993 did the study group present its 'draught' of a modernised Charter, which until the present day has not come any further than the proverbial desk drawer. This lack of progress was initially blamed on the Antillean and Aruban resistance to any changes with respect to the contents of the Charter, which was further intensified by the gradual entrenching of the Dutch position, and furthermore by the continuous and undecided discussions regarding both the internal political structure of the Antilles-of-five and the mutual relations between the Caribbean islands.

The many policy documents of Minister Hirsch Ballin made continuous reference to 'governmental support', 'strengthening of the guarantees for democracy and the constitutional state', 'cooperation in the upholding of legal principles' and 'professionalisation' of the Caribbean administration. This line of policy reflected the view that the overseas administration was 
suffering from years, if not decades, of neglect, not only domestically but also by the Dutch. This administrative weakness was considered all the more dangerous in view of the perceived new threats from international crime, which at the end of the 1980 os became a heated issue on the political agenda; a threat barely conceived before this time, but now quickly gaining a foothold within the Kingdom.

In March 1990 the International Financial Task Force on Money Laundering pleaded for far-reaching measures in order to combat money laundering, in particular concerning fortunes derived from drug trafficking. These measures would in practice, certainly in the short-term, have negative consequences for the Antillean and Aruban offshore banks. Still, from a meeting of the Council of Ministers of the Kingdom it becomes clear that all three countries were in support of the proposed measures, be it with the insistence by the Antillean and Aruban delegates that international policy regarding the Kingdom, especially when affecting the Caribbean countries so directly, would not solely be dictated by the Netherlands. A brief examination of discussions within politics and the media during the following years confirms the impression that pious hopes such as these were in vain. Where the Netherlands had different priorities to those of the Antillean and Aruban governments, it was generally prepared to act upon them, regardless of the views of its Caribbean partners.

The most dramatic example of this was the mechanism of supervision established by the Kingdom government on the island of St. Martin. For quite some time there had been reports in the Dutch media finding fault with the Dutch part of St. Martin under the leadership of local Democratic Party leader Claude Wathey. Rumours suggesting far-reaching corruption within the island administration were increasingly supported by hard evidence. A report of the Antillean audit (1991) confirmed that St. Martin's administration was inadequate at least. From August 1990 the Antillean Public Prosecutor was even investigating possible ties between island administrators and the Italian maffia. There were clear indications as to the likelihood of this.

Fully in line with new Dutch policy, Hirsch Ballin decided to deal with the situation head on. He did not stand alone in this. When the budget for Antillean and Aruban Affairs was being discussed within Dutch parliament in October 1991, a unanimous desire to intervene in the administration of St. Martin became apparent. The Antillean government under Premier Maria Liberia-Peters - in which St. Martin's Democratic Party had a crucial representation - eventually had to concede and in December 1991 appointed the 'Commission for the Investigation of Decision Making on St. Martin', chaired by Miguel Pourier. Its report, issued in May 1992, clearly concluded that the island administration was failing completely; democratic rules were flouted, the democratic checks and balances were not functioning. The Dutch cabinet deemed rapid action necessary and did not exclude 
the use of unorthodox measures. However, apprehensive of strong Dutch interference with what it saw as primarily an internal Antillean affair, Willemstad displayed reservations. Hence, a full six months of discussions ensued - in which Premier Liberia-Peters and Minister of Justice Suzy Römer played a leading role on the Antillean side - before an Order in Council (algemene maatregel van rijksbestuur) was issued on 2 February 1993 by the Kingdom government 'holding several temporary provisions in the administration of the island of St. Martin'. The reasoning being that the island's administration was 'grossly neglected', and that the available legislation failed to ensure supervision by the Antillean state or the Kingdom; hence the necessity for 'special measures'.

From the start, Dutch politics and the press reacted very positively to this enforced - temporary - curtailment of national and island autonomy, which, on the other hand, received mainly critical reactions in the Antilles. It was not only on the island of St. Martin that political response was negative, but also on Curaçao, where it was well understood that a dangerous precedent had been created: today St. Martin, tomorrow perhaps Curaçao. In January 1994 a Kingdom commission under the Antillean notary E.L. Joubert issued a comprehensive evaluation of the effectiveness of the mechanism of supervision. Taking into account the findings of the commission, the Kingdom government decided to prolong the temporary provisions, originally intended for one year. It was only following the coming into power of Miguel Pourier and the formation of a new Antillean cabinet, in September 1994, that the Dutch handed over the supervision of St. Martin's administration to the national government in Willemstad. However, when one year later - on 5 and 6 September 1995 - hurricane Luís devastated large parts of the island, the extent of the problem of illegal immigrants on St. Martin became apparent, once again feeding doubts and worries. It would not be until 1 March 1996 that the supervision was withdrawn completely and replaced with an administrative agreement between the Dutch and Antillean governments and the island administration of St. Martin.

With this system of higher supervision, for the first time since the Charter had come into effect in 1954, Antillean autonomy had been 'overruled' by the Kingdom government. Dominated by the Netherlands, this Kingdom government had forcefully expressed its lack of confidence in both the island administration and the national control thereof. That this took effect through an 'Order in Council', which by definition is outside democratic control, would form an important element in subsequent discussions on the 'democratic deficit' of the Kingdom.

In the meantime it had become increasingly clear that both the Netherlands and the Antilles were prepared to retain Aruba as a member of the Kingdom. Along with other agreements this willingness needed to be solidified in an amendment of the Charter, which made it necessary to con- 
vene a new Kingdom conference. The Antilles had yet another issue to discuss: Curaçao and St. Martin were resolved to end ties with the Antillean state, which would make a redefinition of relations between the Kingdom, the Netherlands and each Antillean island necessary.

It was unprecedented that this third cabinet under Lubbers was prepared to cooperate with the falling apart of the Antillean state. At the same time, however, the revision of the Charter - as envisaged by the Dutch - was of a completely different order, namely aimed at strengthening the role of the Kingdom. By definition this would be at the cost of Caribbean autonomy, reason enough for Antillean and Aruban politicians to consider the apparent Dutch cooperation with suspicion. In this light it is remarkable that The Hague assumed that during the conference a quick and easy consensus would be reached, so much so that every country and every island was given the same weight, namely one vote.

The 'Future Conference' - the Netherlands had resisted the weightier term 'round-table conference' - was held from 8 until 10 March 1993 on Curaçao. It was a large gathering: 103 participants from the three countries and the five Antillean islands, and 23 observers from the three parliaments. Records of the first round of consultations evoke an image of a coming together of parties with entirely disparate views and priorities. The Netherlands wished to link the now accepted further fragmentation of the Antillean state and the permanence of Aruba's status aparte to the strengthening of guarantees for good governance within the Kingdom - the primary Dutch concern. Prime Minister Lubbers set the tone in his opening speech: 'We are all part of the Kingdom. To say it this way: the Queen is of and for each one of us. Thus one Kingdom, in which we all inhabit one room. Yet this creates obligations. I propose that together we will deal with long overdue maintenance, with respect to good governance, in the first place in one's own backyard and from there on, of course, also communally.'23

However, these 'communal values' were not defined by everyone in the same way and this urging by the Dutch was quickly interpreted by the Caribbean delegates as a lack of respect - a long-established pattern of action and reaction in the Kingdom relations which would continue throughout the 1990s. In hindsight it can be determined that it was almost inevitable that the Future Conference should end in a fiasco. Yet there is no evidence that during the conference itself there was any awareness of this, at least not within the Dutch delegation. Chairman Lubbers would continually approach problematic areas from different angles, hoping to find links between the island objectives and those of the Kingdom, i.e. the Netherlands. With this he was not afraid to step on the toes of his Caribbean counterparts: 'I can only establish from my own observations that in the course of these years things [the quality of government of the islands] have not improved.' Leader of the Curaçaoan delegation, Mendes de Gouveia, repeatedly turned the conversation back to the issue of each island's right to 
self-determination. During this conference Curaçao was expecting to get the green light in its bid to break away from the Antillean state. However, Lubbers would only reiterate his starting point, 'the unbreakable ties between a good political organisation and a strong administration, like Siamese twins'. There were also clashes with the other islands. R.A. Richardson of St. Martin did not beat about the bush: 'What is good for Holland, is not necessarily good for St. Martin, Saba nor St. Eustatius. ${ }^{24}$

These disparate views would continue to give rise to conflict. Even the astonishing Dutch promise that all islands could establish direct ties with the 'mother country' did not bring relief. Lubbers' final attempt at consensus - regarding this option of direct ties with the Netherlands along with control of financial and administrative matters - met with the 'deep disappointment' of the Curaçaoan delegation. Next, to the total surprise of the Dutch delegation and gathered press, the Antillean Minister of Justice Römer dramatically tore up Lubbers' proposals. Despite this rebuff the Dutch delegation would continue working on the same track. On the final day of the conference it presented all parties with an 'improved piece', the conclusion of which Lubbers summarised: 'We offer the green light to Aruba, Curaçao and possibly St. Martin [to become countries within the Kingdom]; the guarantee of stability for the other islands and direct links with the Netherlands, along with the second track of communal regulations, which we have to elaborate upon with trust amongst ourselves. ${ }^{.25}$ Yet later that afternoon Lubbers would for the first time articulate that the conference could not be concluded successfully since an agreeable answer had not been found 'to the reconciliation of the disparity found in the desired choice of increased autonomy and the systematics of dealing with each other within a Kingdom that can guarantee good governance'. ${ }^{26}$ After three hectic days, the Future Conference was closed without a firm conclusion.

Former Plenipotentiary Minister of Aruba, Mito Croes, who attended as a spokesman for the Aruban opposition, characterises this conference in hindsight as 'a sham, an act, a drama'. He attributes this to insufficient preparation by the Netherlands, and the Dutch lacking the insight to assess the political situation correctly. In the Dutch press criticism focused on the approach by Lubbers and Hirsch Ballin, which was described as power play. Shortly after the conference Lubbers stated that he had consciously chosen 'to confront, not to clash', in the hope of breaking through the deadlock, but the press would continue to emphasise that the Antilles and Aruba had seen this as an attack. ${ }^{27}$

At the closing of the Future Conference - 'not failed, but not yet successful $^{128}$ - Lubbers had spoken optimistically of its continuation, which indeed came about at the end of June 1993, again on Curaçao. The Netherlands pitched it high. Once again focus was on the realisation of a 'renewed legal order', to be implemented as of 1 January 1996 . Within this structure each island would be an autonomous part of the Kingdom; the Antilles 
would be discontinued, the national functions managed by the Netherlands unless an island preferred these responsibilities to be taken over by another island. Curaçao would receive and Aruba would keep the status of country; the other islands would become 'Kingdom islands' on the understanding that eventually also St. Martin and even Bonaire could become countries and would be supported on their path to this objective. However, the Caribbean delegates were not prepared to discuss their autonomy in exchange. And they would persevere in resisting the Dutch pressure, which was perceived as insulting.

In the end this second conference was one of bilateral meetings, comprising many head to head meetings between the Dutch and the individual island delegates. Agreements were made with specific islands only: $\mathrm{Cu}-$ raçao could become a country immediately. St. Martin and Bonaire were given this option. The smallest islands would possibly attain direct ties with the Netherlands. A Dutch civil servant noted on the prevailing mood among the representatives of the smallest islands: 'One still has the uncertain joy of the child that has received a gift which it feels to be unaffordable by its parents. ${ }^{.29}$ Meanwhile however, no agreement had been reached on the Dutch desires for good governance, let alone on a rapid revision of the Charter.

Somewhat outside the agenda of the bilateral talks, the Netherlands discussed with Aruba the consequences of the removal of the Statute's article 62, concerning Aruba's independence. These consultations resulted in a Protocol that coupled the consolidation of political ties with certain preconditions, including the intensification of cooperation in the fight against international crime and provisions regarding the lawfulness of Aruba's administration, fiscal relations and an adequate financial policy. Aruba would also cooperate in the legal implementation of a development fund - the 'solidarity fund' - for the weaker islands. All this bore the hallmark of Dutch political thinking, but at the same time it was unmistakable that Aruba would not relinquish any autonomy voluntarily.

With this Protocol the sword of Damocles was lifted, and finally taken away in 1995. Under the first cabinet of Wim Kok (1994-1998) Aruba achieved what it had been desiring for so long: article 62 was deleted from the Charter. Plenipotentiary Minister Croes stated almost triumphantly: 'We managed to convince the Netherlands to amend the Charter on two occasions. Initially with the status aparte, and then with the cancellation of independence. Quite an achievement for a small island, nobody could have imagined this.' Reminiscent of his own party's strong allegiances with Dutch Christian democrats in particular, he adds: 'We have been able to do so only because of cunning public relations. ${ }^{30}$

The new Dutch policy, begun during Lubbers' third term, confirmed the continuation of the transatlantic Kingdom, but failed in its ambitious objective to fundamentally revise relations under the Charter. The eventual 
failure of the Future Conference would seal this. Follow-up talks had been postponed until later in 1993, when the results of a scheduled Curaçaoan referendum on the political future of the Antilles would be known. Curaçaoan politicians expected the electorate to support their desire to break up the Antillean state. Yet the results of this referendum mainly illustrated the large divide between public opinion and political direction: an overwhelming majority $-86 \%$ - voted in favour of continuing the Antilles-of-five. Similar results were recorded in referendums held on the other islands, with the partial exception of St. Martin where the separatist movement was still strong. A political landslide would ensue, with discussions on the internal Antillean structure entering a new phase. Now that the prospect of an imminent breaking up of the Antillean state was dismissed, at least for the time being, Willemstad refused to even consider any changes in the Charter before having reached a decision regarding the future political structure of the five-island-state. For Aruba any urge to revise the Charter had already disappeared when the article on independence had been deleted.

With this, the Dutch lost any leverage they may have had over the islands to push for a fundamental change of the Charter. Hirsch Ballin stated in hindsight: 'Our striving for a revision of the Charter could only have succeeded if on the Antillean side there had remained some interest in an exchange.' Whereas from the start, Dutch wishes to rewrite the Charter had been linked to three themes - finance, administration and law enforcement within both Caribbean countries - Hirsch Ballin had been forced to 'shelve the option of amending the Charter to these ends as remaining an unfeasible objective'. Yet regarding the other dossiers, he considers, 'sufficient results have been reached'. ${ }^{31}$

On the islands Minister Hirsch Ballin was, and still is, spoken of with mixed feelings. He initiated a serious breach with former Dutch policy: removing independence from the table, strengthening the Kingdom relations and, to this end, revising the Charter. A more pushy attitude towards the Antillean and Aruban politicians was part of this policy - and this was disconcerting to some. Former Prime Minister Lubbers recalls: 'In the field of good governance Hirsch Ballin was more stern and strict in his approach. If I said to Jan [de Koning, Hirsch Ballin's predecessor]: "Do not act so amicably with those people”, then I said to Ernst [Hirsch Ballin]: "Act a bit more amicably with them."' Former Antillean Premier Liberia-Peters states: 'With Hirsch Ballin came the air of haste, push push push.' Her successor Suzy Römer judges with more nuance: 'With Hirsch Ballin a new type of Dutch politics began. It is the characteristic of a new era, with Hirsch Ballin coincidentally being in the right place at the right time. ${ }^{32}$

Meanwhile the gap between the islands and the central government in Willemstad remained large. There had been hopes for change, after the political landslide of 1993 and 1994. In view of the intended national restruc- 
turing, based on a redistribution of responsibilities between the nation and the five islands, in July 1995 an Antillean commission issued the report titled Make it Work; Model for a Restructured Antillean State. This programme, presented as a 'complete package', revealed cautious ambitions. The Antilles would become a federal structure, in which the 'equality' of all five islands would be paramount. There was much written and much debate about this possibility. But in actual fact very little changed, the élan disappeared and the much needed restructuring is still in the pipeline while island centrifugalism persists.

\section{Deadlocks and the Margins of Autonomy}

In the first ever 'purple' cabinet (social democrats with conservative liberals), led by Prime Minister Kok (1994-1998), Minister of Defence Joris Voorhoeve succeeded Hirsch Ballin to become the last Minister for Antillean and Aruban Affairs. With the inheritance of a stalemate, Dutch ambitions would not fundamentally change. ${ }^{33}$ The emphasis lay on the assurance of optimal conditions for good governance, within the constitutional framework as it had been determined in 1954. In this respect the government declaration still mentioned the need for a 'revision and modernisation of Kingdom relations'. One year later, however, it was indicated that the desired restructuring of the Antilles would become the primary constitutional goal. Pragmatism dictated Voorhoeve's priority reshuffle, encouraged by the understanding that the Antilles and Aruba did not desire a thorough revision of the Charter and that they could not be forced into it. In October 1995 Voorhoeve argued that 'we should not wait with tackling serious social problems within the Kingdom until we acquire a neatly revised Charter. Within the confines of the current Charter we may already solve a lot of problems. 34

Shortly after his coming into office Voorhoeve presented his colleagues and the chairmen of the four major parliamentary parties with three 'theoretical models' for the future of the Kingdom. The first option involved a distancing of the Caribbean countries by interpreting the Kingdom ties as merely a Commonwealth. The second option came down to continuing the status quo, probably the easiest choice, but according to Voorhoeve within the current international context - with its growing emphasis on good governance - a risky one. This led to the third option: a strengthening of the Kingdom ties. Voorhoeve expected administrators in the Caribbean to be more inclined to make a plea for a 'downward rather than an upward revision of core competences'. Hence his plea for pragmatism, coming down to a gradual but consistently pursued enhancement and strengthening of relations while leaving the Charter unaltered for the time being. Results could only be expected in the medium- to long-term, Voorhoeve added. 
Discussions regarding a fundamental revision of the Charter would 'only receive political clout if the Kingdom partners are prepared to think and talk cooperatively'. ${ }^{35}$

However, the Dutch parliament thought differently, as it expected the minister to approach things more actively, and thus insisted on reviewing the political structure of the Kingdom whilst considering possible alternatives for the Charter. This was in vain. The 'study of models' that Voorhoeve had prepared never saw the light of day. While the study was discussed during the spring of 1998, the ministers of Kok's first cabinet, with elections approaching, did not determine a position. State Secretary Gijs de Vries, responsible for Antillean and Aruban Affairs during the second purple cabinet under Kok, would ultimately convince the House of Commons that publication of the study was inopportune, and there it ended. The House proceeded to retract its earlier more active steps.

As stated previously, on 1 January 1996 Aruba obtained its permanent status aparte. In the same year the island came close to a direct Kingdom intervention, which soured the euphoria of its now fixed status as a country. For some time doubts had been circulating regarding the quality of Aruba's administration. In March 1995 a strictly confidential draught report was issued within Dutch political circles stating that Aruba had 'grown into one of the important centres for the money laundering of hundreds of millions of guilders' ${ }^{36}$ The report would only become more widely known two years later, causing considerable concern.

The Dutch distrust concerning the integrity of Aruba's administration was considered a great injustice on the island. Apparently it was not so much associated with the economic boom which had become visible in the meantime, but rather with Mafia practices. Mito Croes, at the time Plenipotentiary Minister, recalled the atmosphere of those days with disgust. It took heated discussions between Voorhoeve and Aruba's Premier Eman before the air was temporarily cleared, only to escalate once again due to a fierce and seemingly unsolvable conflict between the highest ranking police officers of Aruba and the - Dutch - attorney general on the island. The Hague felt that the Aruban government was jeopardising the independent functioning of the public prosecutor by supporting the police. In an effort to restore trust, in September 1995 a bilateral Protocol for 'Cooperation between Aruba and the Netherlands in the Fight Against Crime' was signed, arranging for cooperation on many levels. In May 1996 this was followed by the establishment of the Commission de Ruiter 'to investigate Kingdom relations with respect to the upholding of criminal law on Aruba'. After a difficult start this commission worked energetically and quickly published its report in October 1996 titled With All Respect.

Harsh conclusions were drawn. The report recommended replacing the police hierarchy. In addition, much to their indignation, the Antilles were brought into the equation by the proposal to unite the Antillean and 
Aruban public prosecutors under one roof. Premier Eman and his cabinet distanced themselves from these recommendations. The already delicate situation further escalated the following month, due to the visit of the leaders of the four main Dutch parliamentary parties to the Antilles and Aruba. Leader of the conservative liberal vvD, Frits Bolkestein, who at an earlier stage had disqualified Aruba with terms such as 'robbers' nest', again voiced harsh words regarding the island's administration. 'The strong suspicions that on Aruba much occurs that cannot tolerate the light of day, are confirmed', so he stated in the press. ${ }^{37}$ The tone seemed set. Yet Kok telephoned Premier Eman, who later openly declared that in a 'heartwarming' and extensive conversation the Dutch prime minister had approached him in a completely different manner from the 'disappointing and undeservedly cold, hurtful, attitude of the delegation of the House of Commons'. ${ }^{38}$

Gradually trust would be re-established. The Eman administration enhanced its own reputation by paying attention to good governance itself. An example of this is the report Calidad (October 1997), in which an Aruban study group expressed ambitious objectives for the improvement of the quality and integrity of Aruba's administration. Clearly the island politicians were growing aware that changes needed to take place within the local administration. At the same time, the complexity of an administrative intervention in a context where both Caribbean countries attribute priority to the preservation of their individual autonomy became apparent once more. Thus The Hague ultimately renounced from its intention to unite the two public prosecutors as had been proposed by de Ruiter.

The renewed Dutch emphasis on good governance and the observance of fundamental human rights and freedoms also led to sharp discussions in a different field, the Antillean prison system. In the beginning of the $1990 \mathrm{~s}$ The Hague severely criticised the situation in the Curaçaoan prison Koraal Specht, where the treatment of prisoners sharply diverged from the norms and standards for human rights to be observed within the Kingdom, again according to the Dutch. After having urged Willemstad several times to deal with the problem, with an impatient Dutch parliament increasing pressure through different channels, in March 1998 a covenant was concluded between The Hague and Willemstad in which the Antillean government committed itself to gradually improving the situation within the prison. Since then the situation has indeed improved with considerable Dutch financial support. ${ }^{39}$ Behind the practicalities, one once again senses differences over the values which are to be implemented. While the Dutch view centres around abstract human rights, the Curaçaoan view is that with such serious social and economic problems at hand, investing millions of euros to enhance the quality of imprisonment to European standards, and hence far above the regional standard, is absolutely ridiculous.

In itself, the covenant may be seen as part of a new Dutch strategy aimed 
at developing instruments for intervention 'by the Kingdom' via an administrative detour, when resort to the heavier instrument of an Order in Council is deemed either unfeasible or undesirable. Hesitation to go any further shows, once again, the difficulty of any unilateral - Dutch - action within the Kingdom. As was to be expected in the meantime Antillean administrators have frequently expressed their dissatisfaction with these and other 'attacks' on their autonomous powers, which is, however much one can understand Dutch humanitarian objectives in this specific case, in itself not totally misplaced.

Its geographic location between the important production centres and markets for drugs, along with the small size of the islands, makes the Caribbean extremely vulnerable to infiltration by international criminal organisations. During the last decade this has had fundamental consequences for the international agenda of the Kingdom, particularly for its external relations, with the fight against international crime and its implications for Dutch society having risen ever higher on the political agenda.

Yet although the Dutch saw the danger, they had long remained reticent in accommodating Caribbean proposals to establish a naval coastguard patrolling the waters around the Antilles and Aruba. Already in 1987 Aruba had requested for the Royal Dutch Navy to assist in the protection against drugs gangs operating at sea. The discussions about this initiative once again illustrate that handling these matters on a Kingdom level thwarts more often than not the Caribbean emphasis on local autonomy. It was not until late-1994 that a model for a coastguard came into being - after consultations between Aruba, the Antilles and the Netherlands - which included a Kingdom law as the basis for the organisation. The Netherlands would be paying two thirds of the costs involved, both Caribbean countries would combine to pay a third. Both the Aruban and Antillean governments were of the opinion that the coastguard should be implemented rapidly, and agreed with the suggested set-up. The Antilles however were soon whistled back by its own Staten, believing the coastguard to be an inadmissible attack on Antillean autonomy. The Antillean government and The Hague were at loggerheads for some time until a compromise was reached which the Staten considered more in line with Antillean autonomy.

Thus, following the advice of the Council of State of the Netherlands, as of 1 February 1996 the coastguard has been functioning on the basis of an Order in Council of the Kingdom. The Antilles, Aruba and the Netherlands (the Royal Navy) have brought in personnel and equipment. The intended operational strength, however, has still not been reached. The coastguard closely cooperates with the American Drugs Enforcement Agency (DEA), which highly values the partnership. There indeed have been tangible results since, in terms of drugs vessels taken and arrests made, but there is little reason to affirm - nor reasonably to expect - that any war on drugs is being won in the waters of the Dutch Caribbean. An evaluation of the trajectory 
of the coastguard therefore leads to mixed conclusions. On the one hand, this is indeed an example of a shared willingness to face international crime in the context of new institutional arrangements within the Kingdom. On the other hand, the long bickering regarding the division of responsibilities and competences demonstrates that autonomy has remained a thorny issue, to say the least. A definitive legal framework for the coastguard is still in the making. ${ }^{40}$

Over this period, with the closure of the military bases in Panama, the United States was looking for new strategic locations in the region. Both Aruba and Curaçao, with the backing of the Dutch government, were keen for the economic opportunity and wanted to play a part on the international stage and so in 1998 welcomed the Americans onto the islands, initially for a period of ten years. ${ }^{41}$ Construction for these bases for Forward Operations Locations (FOL) started in January 2002. By then, of course, "September 11" had put issues of international security and terrorism high on the Kingdom agenda; only two months later the three Kingdom countries agreed on a communal defensive strategy in this respect. In this new context the FOL have acquired heightened significance. As bases for surveillance flights in the Caribbean and over Colombia, they have almost inevitably become part of the growing U.s. intervention in this country, where drug trafficking and guerrilla warfare, now renamed terrorism, are perceived as a threat to vital American interest. That all of this may also have direct implications for security issues in the Kingdom is evident. Even if the Kingdom has explicitly stated that it would not allow the FoL to become instrumental in American military interventions in the region, this message might well be lost to its adversaries. Thus critics have warned that the Fol may expose the islands to terrorist attacks.

Finally, in 1996, due to a renewed conflict of interests, a serious controversy occurred within the Kingdom. Since the beginning of the 1990s ironically, at the initiative of the European Commission itself - the Antilles and Aruba could claim specific trading advantages to the European Union on the grounds of the so-called 'Overseas Countries and Territories Decision', which aims to promote the economic, cultural and social development of the overseas countries and territories. The three Leeward islands were benefiting considerably from this provision by lightly processing rice from Suriname and Guyana, after which the rice could be imported into the Union as an 'Overseas Countries and Territories' product, thus formally 'European' and free from import duties.

However, Brussels considered this profitable 'Antilles route' as an improper use of the regulation. According to the European Commission the processing of rice on the Leeward islands was mainly symbolic. Italy, Spain - rice producers themselves - and eventually France became dogged opponents. In February 1996 the European Commission attempted to end the Antilles route once and for all, a decision supported by all member coun- 
tries, except the Netherlands, who did not want to fail its Caribbean partners. Yet confronted with the other fourteen member states, The Hague would eventually support the European Commission's decision to assign the Antilles and Aruba a very limited quota for rice. The same would soon apply to sugar imports via the Caribbean islands under the LGO regime. ${ }^{42}$ Thus two potentially promising productive sectors were cut off in an early stage.

Even though this position did not bode well with the spirit of the Charter, with its obligation to 'mutual assistance', it is in line with the current direction of the Netherlands establishing its priorities in Europe with conviction - the Netherlands being in the process of transferring much of its own autonomy to Brussels. The Antillean and Aruban governments made use of all possible political and judicial options for the Dutch to reconsider, but to no avail. Much to Caribbean chagrin, Dutch priorities proved to lay firmly within the European Union and outweighed Caribbean interests. Overseas there was naturally a strong feeling of having been let down, all the more painful since, during the 199os, the Netherlands had relentlessly advocated the need for unity within the Kingdom, appealing to the necessity of observing the same administrative norms. The painful realisation that Europe mattered far more to The Hague than the 'Dutch' Caribbean provoked strong reactions, and as a result relations soured for some time.

\section{Into the Twenty-First Century}

Looking back on the closing years of the last century and the beginnings of this, the first and obvious conclusion must be drawn that The Hague's priorities were anywhere but in the Caribbean. While its policies for the Antilles and Aruba were mainly dictated by a longing to alleviate itself from the liabilities arising from such thorny issues as migration and economic dependence, many island politicians failed to consider rising Dutch irritations and instead remained counting on an undisturbed prolongation of the status quo. At the same time, The Hague has shown little inclination to allow the Antilles-of-five to further disintegrate. A brief analysis of Kingdom relations under the second 'purple coalition' may illustrate these points.

Since 1998 the Kingdom Affairs have been housed, rather symbolically, within the Ministry of the Interior. The nomadic Cabinet for Antillean and Aruban Affairs (KabNA) no longer exists. A directorate-general with its own state secretary - although under the ultimate responsibility of the Minister - within the renamed 'Ministry of the Interior and Kingdom Relations' replaced KabnA. ${ }^{43}$ These institutional changes illustrated the permanence of the Kingdom ties, however restrictive they are regularly felt to be. In retrospect KabNA was seen as inefficient and far too lenient. In fact, within a year virtually all of the KabNA staff were reappointed to other ministries or di- 
rectorates. While a fresh start was made, much human capital was removed from the new directorate-general which was now supposed to keep a safe bureaucratic distance to the Caribbean partners. It remains to be seen whether in the long run the new institutional framework will strengthen the basis for tripartite decision making.

Within this new arrangement the outlines of the Dutch policy towards its Caribbean territories did not change significantly. In 1999 Gijs de Vries, the first State Secretary appointed for Kingdom Relations, presented his policy statement Toekomst in samenwerking ('A Future in Cooperation'). Economic recovery and stability, and the attainment of independent growth were top priorities in the document, which leaned heavily on two reports previously published under the auspices of the Antillean and Aruban governments. ${ }^{44}$ In a sense then, much of Toekomst in samenwerking also reflected Caribbean insights. Yet until the present day, Caribbean politicians recount with indignation that the Netherlands had broken with tradition by unilaterally formulating the way ahead, in passing curtailing several sectors of development cooperation.

In essence, priorities remained much the same as they had been for his predecessors, the Ministers Hirsch Ballin and Voorhoeve, all through the 1990s. De Vries called 'the furtherance of the highest possible degree of selfsufficiency of the Kingdom partners' the 'central objective' of the new cooperation policy. This intention was not new, but in comparison to previous cabinet periods an ever stronger emphasis was placed on the responsibility to be borne by the Caribbean partners themselves and on the conditions they had to comply with in order to qualify for Dutch support. Notions such as modernisation, effectiveness and sustainable development were constantly advanced in Toekomst in samenwerking, alongside the necessity of a transition towards programme financing. With regard to all of this the first matter of importance was that the Caribbean partners themselves would have to comply with these conditions before the Netherlands would be willing to implement a 'new cooperation policy'. During de Vries' period in government, these conditions were constantly reduced to the core: a firm financial and economic policy together with good governance. ${ }^{45}$

Toekomst in samenwerking thus gave priority to the strengthening of the economic foundations of the islands and the reconstruction of public finance; the continued advancement of good governance; and the development of a migration policy aimed at curbing - not ending - the emigration wave, as well as a more adequate welfare policy for Antillean immigrants once they arrived in the Netherlands. New in all of this was a severity manifested in the continuous hammering home of conditions that needed to be fulfilled to qualify for future Dutch assistance. For the time being, regular development aid would continue, even if strictly centred on four sectors good governance, the functioning of the judiciary, durable economic development and education - in future channelled through long-term pro- 
grammes managed by Aruban and Antillean development agencies rather than by the respective governments. Regular aid during the second purple coalition, in spite of strong oscillations, in the end remained at roughly the same level as in the previous period. At the same time The Hague committed itself to provide an additional 217 million Dutch guilders (some 100 million dollars) to the Antillean government as budgetary assistance to help accommodate the social costs involved in the restructuring of its finance and bureaucracy. The Hague and Willemstad agreed that the International Monetary Fund (IMF) would play the role of arbiter in this trajectory. ${ }^{46}$

This IMF trajectory started in 1999 and was expected to be completed three years later. In practice the whole process came to a premature halt in 2001, leading to deep frustration on both sides. As of 1999, the Antillean government initiated a series of measures with the objective of liberalising the economy, narrowing the bureaucracy and its role in the economy, and balancing the budget. Tangible advances towards these goals were indeed made, with a 35 per cent shrinking of the civil service, a substantial restructuring of government finances and a reversal of the trend of negative growth rates. At the recommendation of the IMF, The Hague made the promised extra budget conditionally available in 200o. The good news ended soon after, and even today strong disagreement remains among the protagonists as to what exactly happened and who is to blame. The Antillean point of view is that The Hague repeatedly came up with new demands, pressuring the IMF to back up Dutch reticence. From this perspective, The Hague's reticence severely hindered a successful completion of the IMF trajectory. The Dutch version is rather that as the trajectory proceeded, the Antillean government time and again refrained from making the necessary last steps. Either way, the result is that the promised budgetary assistance was not paid out in full, at least not fully as budgetary assistance. Meanwhile the dispute over this issue has soured relations considerably. Ironically, the IMF drew moderately positive conclusions in the Spring of 2003 on the economic policy pursued by the Antillean government, even after the official IMF trajectory had been annulled in $2001 .{ }^{47}$

By the time of the ousting of the second purple cabinet in 2002, much of the economic agenda of the Kingdom relations remained as it had been throughout the 1990 and from this there have been real gains. The transition from a development policy based on project financing to programme financing - which had been sought for decades but never realised - was in its final stages of preparation in Spring 2003. The Antillean government continued with a policy of restructuring its finances and civil service. Yet in the Dutch point of view, all of this and particularly the liberalisation of the economy - at the expense of local economic elites holding profitable monopolies, as it is often emphasised by policy makers in The Hague - has not been completed at all. Clearly this will provide fuel for further conflict in 
the near future. Meanwhile it remains questionable whether these policies will indeed bring within reach the long-term goal of self-reliance and thus the gradually fading out of development aid, as both sides optimistically claim. After all, the viability and potential prosperity of these small island economies are limited, especially when compared to the Netherlands, the frame of reference for most Antilleans. This reservation, it should be pointed out, is hardly ever explicitly voiced by either of the protagonists in the debate. ${ }^{48}$

In terms of economic policies and performance, Aruba had become a shining example constantly referred to as the benchmark for the Antilles. Indeed, economic growth in this smallest country within the Kingdom has been spectacular ever since the mid-1980s. Under the AVP-dominated Henny Eman administration, agreements with The Hague, regarding a switch in the development aid from project to programme financing, were finalised in 2000 along with a gradual phasing out of Dutch aid aimed for completion around 2010. However, one of the first moves of the new MEP dominated coalition, which came to power in 2002, was to denounce many of the economic policies of the previous administration. The new cabinet under Nel Oduber maintained that the figures presented thus far to demonstrate the presumed success of the new economic policy had been heavily exaggerated. The very idea of future financial independence from the Netherlands was seriously questioned again, a sobering stance indeed from this 'shining example'. 49

Throughout the 1990s a good part of the development aid had been invested in good governance. This emphasis was maintained with vigour by the last purple coalition. While there had been relatively drastic interventions under the Ministers Hirsch Ballin (Higher Supervision on St. Martin) and Voorhoeve (Aruba), under de Vries there was a rather constant pressure on island politicians to demonstrate their dedication to good governance. And indeed, while there were no spectacular measures, advances were made in the quality of government. Yet by the end of the purple coalition in 2002, doubts and even mistrust regarding the quality and credibility of Aruban and Antillean politics still prevailed in The Hague, as even the state secretary publicly demonstrated in the Dutch press. Such doubts were only fuelled by the pattern of internal accusations of corruption. A recent example of this was a so-called 'Truth Commission' set up by the incoming Aruban government under MEP-leader Nel Oduber to investigate possible mismanagement under the preceding AVP-dominated coalition. Once the commission reported, the effect in The Hague was such that it only confirmed suspicion of the Aruban governmental system, and not particularly of one political party. ${ }^{50}$

Dutch frustration regarding the Antilles has been fuelled by the Antillean exodus, in itself a product of the deep economic and social crisis, particularly on Curaçao. Of course, at the root of the problem is the failure of 
the Antillean economic model pursued up until the mid-199os, characterised by protectionism and an oversized state bureaucracy. Development aid had been one of the instruments to alleviate the deepening crisis. When the Dutch started to make future aid contingent upon structural adjustment of Antillean economic policies, Antillean reactions were predictable. Even if the Antillean government of Miguel Pourier in this respect saw eye to eye with the Dutch, many a local politician stated time and again, thereby sidestepping national responsibilities, that without continued and even increased aid the crisis would only worsen. This crisis, so the argument went, would translate into more migration to the Netherlands; thus the Netherlands would only harvest what its own rigid policies had sown. This point of view was shared by some Dutch politicians as well. Yet the point of view of the purple coalition, and particularly of the new Ministry of the Interior and Kingdom Relations, remained crystal clear: structural adjustment was to be given absolute priority in aid relations. An upgrading of the local social sectors should be the long-term result, not the immediate goal. Thus only education was mentioned explicitly in Toekomst in samenwerking as a spearhead of the cooperative relationship. Within and around Dutch parliament there were critical reactions to the fact that an elaborate social paragraph was missing. Although due to this criticism the policy was slightly redrafted, the Netherlands would not fundamentally redefine its approach.

As stated above, the Antillean government under Miguel Pourier - and under his successor Etienne Ys - has adhered to much of this policy. The coalition did indeed start a restructuring of its bureaucracy and economic policies, and heated debate mainly centred around the question as to whether these measures were sufficient to warrant the temporary extra Dutch aid to alleviate the social costs of, in particular, substantial layoffs. Meanwhile the exodus would escalate. In the late 1990s, migration figures from Curaçao to the Netherlands reached unprecedented peaks, although this surplus has subsided since. By 2002 the number of Curazoleños in the metropolis was estimated to be 115,00o, while the population on the island itself had dropped from a near 150,000 in the mid-1980s to some 130,000. The Dutch reacted to the influx with the establishment of educational programmes for Antillean immigrants in the Netherlands and, if The Hague would have had its way, also on the islands. Potentially more significant was the growing support for restricting migration by legal measures. While this has not been implemented, and indeed most likely cannot be implemented, the idea has become increasingly popular, particularly as attitudes in Dutch society and politics towards immigration and minority issues hardened considerably in the early 20oos. ${ }^{51}$

The Antillean migration to the Netherlands and its inherent problems in a handful of Dutch cities came to weigh ever more heavily on Kingdom relations. High figures for unemployment and criminality underlined the 
fact that insufficient mastery of the Dutch language of many Antillean immigrants makes integration problematic. Inevitably, as a result, the language issue has also come under scrutiny. Decades of neglect of the Antillean and Aruban education systems, especially as far as the Dutch language is concerned, are at the root of the problem - at least for the Caribbean lower classes. Prime responsibility lies with the Caribbean governments, which for over half a century had both the freedom and the duty to define and implement educational policies. Ironically, the Dutch added to this educational dilemma mainly through their aloofness: over the centuries, colonial government had made little effort in establishing a Dutch language educational system in the Antilles, and after the proclamation of the Charter the Dutch did not give priority to questioning Caribbean autonomy in the field of educational policies, even if there were indications of degradation of the quality of education. As the Netherlands in the 199os started counting the costs of this historical oversight, some thought was also given to ways of upgrading the Dutch language in overseas education, primarily because schools are producing potential migrants to the Netherlands. Yet with reluctance on the Caribbean side to 'go Dutch', concrete achievements have been thin on the ground. ${ }^{2}$ -

As a result, in spite of real advances made in the field of economic restructuring and good governance, Dutch frustrations over the Antillean exodus and the perceived lack of overseas political credibility - not so much of the leadership of the likes of Governor Jaime Saleh and Prime Minister Miguel Pourier, but certainly of the Caribbean political system as such produced a hardening of the debate in the metropolis. A fortnight prior to the May 2002 elections, the outgoing State Secretary de Vries published an article in a leading Dutch newspaper in which a summary of achievements accomplished during his period in government were overshadowed by his apparent frustrations and clear warnings. He concluded that the results of the development aid were 'insufficient', he wrote of a lack of political will for reform in the Antilles, pointing at clientelism and political mismanagement, and spoke out against future Dutch concessions in the fields of aid and constitutional reform if the Antilles would not abide by IMF directions. This parting statement would cause deep and lasting indignation in Antillean circles and particularly with the Antillean Plenipotentiary Minister in the Netherlands - clearly bringing deep divisions regarding mutual reliability to light. ${ }^{53}$

Another impetus for a possible revision of the Charter was provided by the renewed drive of St. Martin to attain country status within the Kingdom, and the new momentum regarding a possible dismantling of the Antillean five-island-state stemming from this. On 23 June 2000, a plebiscite revealed that a clear majority, seventy per cent of the inhabitants of the Dutch side of the island, opted for a separation from the Antilles and a country status within the Kingdom. The immediate Dutch reaction - both 
within government and parliament - to this plebiscite and St. Martin's Island Council's urge for discussions on the issue was predictable: this is an internal Antillean affair, and anyway there are other, far more urgent priorities in the Kingdom relations. In May 2002 however, a new dimension was added as the incoming Antillean government under Etienne Ys squarely stated in its coalition agreement that 'this government will be the last of a constitutional unity of the Netherlands Antilles in its present form', and that 'St. Martin will secede from the Netherlands Antillean constitutional entity and attain the status of country within the Kingdom during this period of government 2002-2006.54

Obviously these and other pertaining formulations suffer from the same incongruence as Dutch statements to the effect that the Antilles and Aruba 'will have to' opt for either independence or a departmental or municipal status: decisions to implement the necessary changes in the Charter can only be made with the consent of all partners. However, now that the Antillean government has made its intentions clear, one would expect The Hague to be prepared to at least discuss the issue. Respect is one argument, the fact that already in 1993 the Lubbers administration wholeheartedly supported the dismantling of the Antilles-of-five is another. As the Antillean coalition agreement was published after the elections in the Netherlands, the outgoing Dutch State Secretary for Kingdom Affairs de Vries could easily choose to keep this file closed. Yet his successors will have to deal with the issue, and could well opt for negotiating towards a compromise in which changes in membership of the Charter will have to be paid for by changes in its content.

Thus the fundamental question which the purple coalitions had deliberately shelved has been brought back into the political arena: can and will the framework of the Charter be perpetuated? Both Minister of the Interior and Kingdom Relations Klaas de Vries and his State Secretary Gijs de Vries, following in the footsteps of their predecessor, the last Minister for Antillean and Aruban Affairs Joris Voorhoeve, stuck to the decision to keep this dossier closed. Pragmatism rather than satisfaction dictated this stance. First priority was with finding solutions to the prevailing economic problems and with strengthening conditions for good governance. Much energy would be wasted, they reasoned, in elaborating alternatives for the present Charter when, for the time being, the interests as defined by the Dutch simply diverge too much from the Antillean and Aruban wishes to remain autonomous under the Charter as stated almost half a century ago. Beyond that, The Hague perceived a paralysing internal discord on this issue in the Antilles. In Gijs de Vries' own words: 'This was a debate that was likely to generate much heat, and probably little light.' ${ }^{5} 5$

In a general sense, one may conclude that during the second purple coalition both State Secretary de Vries and the new directorate-general in the Ministry of the Interior and Kingdom Relations have given priority to 
developing a new economic policy and modernising the aid relation. They have been conspicuously weary of engaging in public debate over the future place of the Antilles and Aruba within the Kingdom, Europe and their Caribbean environment. ${ }^{56}$ If much of the criticism levelled at the first and particularly the second purple coalition under Wim Kok concerning its presumed lack of long-term vision and its over-emphasis on pragmatic solutions, then the record regarding its dealings with the Antilles and Aruba may well be regarded as a case in point. Yet the short-lived first coalition under Balkenende would not strike a different chord. The 2002 policy statement again emphasised good governance and particularly, in view of high criminality, a stepping up of Dutch assistance in the field of law enforcement. Even though the possibility of closer integration with the Kingdom was mentioned, at that stage there was no hint at plans to change the Charter. It remains to be seen whether the second cabinet under Balkenende, which took office in May 2003, will be more daring in this respect. ${ }^{57}$

And so at the dawn of the twenty-first century, the Antilles and Aruba have become more intensively linked with the Netherlands than ever before since the promulgation of the Charter in 1954. At the same time more worrying parameters have emerged in the transatlantic relations than were ever anticipated, and immediate solutions are not in sight. In the remainder of this book we discuss three themes which figure prominently as thorny issues - development aid, migration and culture. Finally, we will expand upon possible future directions for the transatlantic Kingdom of the Netherlands. 


\section{Illusions and Benefits of 'Reciprocal Assistance': Development Aid}

An analysis of trends in per capita GDP for all Caribbean countries in the last four decades of the twentieth century reveals a clear picture with perhaps alarming implications for the debate on the costs of independence in the region (table 1$).{ }^{1}$ At the bottom of the historical table composed by a research group headed by Bulmer-Thomas we find Haiti, whose inhabitants are actually worse off materially today than they were in $1960 .^{2}$ The other early sovereign states, the Dominican Republic and Cuba, continue to rank among the poorer Caribbean nations as well. Together the three make up some two-thirds of the total regional population, a sad reminder that the luxurious Caribbean of the tourist brochures is anything but the life of ordinary people in the archipelago. Even so, Caribbean standards of living in general are far above those in Africa and most of Asia. ${ }^{3}$

What if we focus on the economic trajectory of the Caribbean countries which had not yet attained sovereignty by 1945 ? It may provide clarity to begin with the figures for the late twentieth century. Among the ten countries on the top of the list in terms of per capita GDP we find Barbados as the single sovereign state, whereas the bottom ten feature only sovereign states, among these six Commonwealth nations and Suriname. In the middle bracket we find a mix of both sovereign and non-sovereign islands. A simple conclusion seems to be that sovereignty has entailed a high economic cost. Inhabitants of the non-sovereign Caribbean are clearly better off in material terms, even if one takes into account the higher cost of living in these territories and the overall uneven distribution of income. Some nuance is called for, however. First, the economic starting position of the remaining non-sovereign territories was much better; thus, with the notable exception of Montserrat and to a lesser degree Anguilla, all of the non-sovereign territories of the late twentieth century figured high in the list of per capita incomes in 1960 too - no less than eight in that year's top ten. Second, while new states such as Guyana, Jamaica and notably Suriname actually faced economic decline after independence, others such as Antigua, Barbados and the Bahamas improved their position. Caution is therefore required in establishing any sort of one to one relation between constitutional status and per capita GDP. ${ }^{4}$

Having said this, there are obvious economic advantages to non-sovereignty. One of these is direct metropolitan financial aid and administrative assistance, the subject matter of this chapter. There are also other considerations. Bona fide investors tend to value additional securities guaranteed 
1960

U.s. Virgin Island

Netherlands Antilles

Aruba

9,484

Bahamas

8,171

Cayman Islands

6,944

French Guyane

5,370

Martinique

4,360

Guadeloupe

3,788

Puerto Rico

3,364

Antigua

3,055

British Virgin Islands

3,039

Barbados

2,928

Trinidad \& Tobago

1,892

Dominica

1,556

St. Kitts-Nevis

1,402

Anguilla

Jamaica

1,401

1,292

St. Lucia

St.Vincent

Cuba

Grenada

Belize

Turks \& Caicos Islds

Dominican Republic

Guyana

Suriname

Haiti

Montserrat

1,171

1,136
1970

1980

U.s. Virgin Islands

15,109

Bahamas

11,862

Netherlands Antilles 10,805

Aruba

9,968

Cayman Islands

9,002

Martinique

6,399

Puerto Rico

6,253

French Guyane

5,903

Barbados

5,336

Guadeloupe

5,294

British Virgin Islands

4,593

Antigua

3,617

Trinidad \& Tobago

2,763

Anguilla

2,292

Jamaica

1,803

Dominica

1,760

St. Kitts-Nevis

St. Lucia

1,474

Turks \& Caicos Islds

1,453

Grenada

1,396

Montserrat

1,350

1,226

1,098

1,061

Cuba

Dominican Republic

Suriname

Guyana

Haiti
1,701

U.s. Virgin Islands

12,924

Bahamas

12,727

Cayman Islands

12,560

Netherlands Antilles 10,262

Aruba

9,868

Martinique

8,859

Puerto Rico

8,056

Guadeloupe

7,988

French Guyane

7,090

British Virgin Islands $\quad$ 7,034

Barbados

6,764

Trinidad \& Tobago

4,615

Antigua

4,057

Anguilla

3,858

Turks \& Caicos Islds

2,698

St. Kitts-Nevis

2,569

Montserrat

2,443

St. Lucia

2,076

Belize

2,036

Cuba

1,778

Grenada

1,709

Dominica

1,679

Jamaica

1,458

Dominican Republic

1,325

St. Vincent

1,322

776

Suriname

930

767

Guyana

819

471

Haiti 


\begin{tabular}{|c|c|c|c|}
\hline Cayman Islands & 21,123 & Cayman Islands & 23,966 \\
\hline U.s. Virgin Islands & 15,699 & Aruba & 16,186 \\
\hline Aruba & 15,558 & Virgin Islands & 15,398 \\
\hline Bahamas & 13,919 & Martinique & 14,524 \\
\hline British Virgin Islands & 12,156 & British Virgin Islands & 14,010 \\
\hline Martinique & 11,676 & French Guyane & 13,044 \\
\hline Netherlands Antilles & 10,767 & Bahamas & 12,944 \\
\hline Puerto Rico & 10,365 & Guadeloupe & 12,287 \\
\hline French Guyane & 10,177 & Puerto Rico & 12,285 \\
\hline Guadeloupe & 8,508 & Netherlands Antilles & 11,698 \\
\hline Anguilla & 7,991 & Antigua & 8,559 \\
\hline Barbados & 7,340 & Barbados & 7,894 \\
\hline Antigua & 6,980 & Turks \& Caicos Islds & 7,061 \\
\hline Turks \& Caicos Islds & 5,907 & Anguilla & 6,937 \\
\hline Montserrat & 5,652 & St. Kitts-Nevis & 6,716 \\
\hline St. Kitts-Nevis & 4,479 & Trinidad \& Tobago & 4,618 \\
\hline Trinidad \& Tobago & 4,095 & St. Lucia & 3,907 \\
\hline St. Lucia & 3,542 & Montserrat & 3,846 \\
\hline Dominica & 2,862 & Grenada & 3,347 \\
\hline Grenada & 2,819 & Dominica & 3,310 \\
\hline Belize & 2,543 & Belize & 2,725 \\
\hline St. Vincent & 2,168 & St. Vincent & 2,635 \\
\hline Cuba & 1,988 & Dominican Republic & 1,799 \\
\hline Jamaica & 1,651 & Jamaica & 1,559 \\
\hline Dominican Republic & 1,366 & Cuba & 1,475 \\
\hline Suriname & 787 & Guyana & 825 \\
\hline Guyana & 554 & Suriname & 710 \\
\hline Haiti & 481 & Haiti & 370 \\
\hline
\end{tabular}


under a metropolitan flag, ranging from legal matters through armed protection of their investments. Then there are the perks of subsidies granted by metropolitan governments - plus, for the European dependencies, European Union programmes - all aimed at the stimulation of the economies in their own territories. Furthermore, open migration channels help to lower the cost of the educational system, particularly in higher education, and to siphon off the social and economic cost of unemployment, as many unemployed simply chose to leave.

Here again a proviso should be made. While there is the larger question of how non-sovereignty may have a negative impact on local economic initiative on all levels, there are more tangible effects too. Thus the fact that emigration rates from the non-sovereign Caribbean are extremely high not only reflects the easy access to the metropolis and the acute awareness in these Caribbean communities that although their island might be prosperous in regional terms, standards of living are higher and opportunities perceived as greater in the metropolis. ${ }^{5}$ There is also a strong push factor in terms of extremely high unemployment figures which seem to indicate that relative prosperity has come, at least in most of the non-sovereign Caribbean, at the cost of a continuous decline in competitive power. There are exceptions. Over the past fifteen years Aruba has managed to achieve full and growing employment centred around tourism and an expanding service industry. The overall record of the British overseas territories which actually received relatively little aid - is rather positive in this respect too. Yet unemployment figures elsewhere in the non-sovereign Caribbean are astonishing. Even after the mass exodus of the late 1990s, which included a high proportion without work, unemployment on $\mathrm{Cu}-$ raçao is still estimated to be some $16 \%$. The French départments d'outre-mer are the regions with the highest unemployment figures - around 30\% within the European Union. Puerto Rican unemployment has also been notoriously high ever since the 1970s, again despite mass emigration to the metropolis. The current rate of $12.3 \%$ amounts to almost three times the national average. ${ }^{6}$

In other words, metropolitan tutelage and aid may have helped to create relatively high per capita GDP figures and thus, one assumes, more comfortable standards of living for those living in the non-sovereign territories of the Caribbean, but it has not enhanced the capacity to fend for oneself. In most cases it seems to have resulted in exactly the opposite, a growing dependence on metropolitan support. With this sobering conclusion in mind, we now turn to an analysis of the Dutch development policy for its Caribbean territories, a policy aimed explicitly at precisely the opposite, the enhancement of economic self-reliance. 
The preamble of the 1954 Charter documents the preparedness of the partners in the Kingdom to 'attend to shared interests and provide reciprocal aid on a footing of equality'. In accordance with this principle the third chapter, 'Reciprocal assistance, consultation and cooperation', formulates guidelines for economic, social and cultural assistance between the countries of the Kingdom. Article 36 roundly states that 'The Netherlands, Suriname and the Netherlands Antilles confer one another help and assistance.' It was precisely these clauses that were often singled out as the core of the new framework at the time of the negotiations concerning the Charter. Indeed, during the 1950 s and 1960 s economic - and to a much lesser extent cultural - cooperation figured at the top of the agenda. It soon became clear that the presumed 'reciprocity' of assistance was mainly an expression of mutual respect bound to remain a fiction, particularly in an economic sense. This in itself undermined another linchpin of the Charter, namely the idea of mutual equality. ${ }^{7}$

Suriname had produced a deficit to The Hague since time immemorial. Conversely, from the 1930s until late in the 1950s, the Antilles had actually produced a positive balance to the Dutch treasury - a rarity in the entire colonial period. When the Charter was signed, per capita income in Aruba and Curaçao was far above the metropolitan figure. However, by then the boom of oil refining was already drawing to a close. Of course, the metropolis was to go through an economic miracle itself - initially aided by the American Marshall Plan - with real per capita income doubling between 1955 and 1975. In the subsequent quarter of the century the standard of living would continue to increase by another sixty per cent to some $\$ 25$,0oo by $2000 .{ }^{8}$ In the same post- 1975 period official per capita income stagnated in the major Antillean island of Curaçao to around $\$ 12,000$ in 200o. Only Aruba achieved considerable real growth, with figures provided for 2000 ranging from $\$ 20$, 000 to an amazing $\$ 28$, 000 GDP per capita at the turn of the millennium according to the U.s. Central Intelligence Agency, well above the estimates given in table 1 and also above the metropolitan figure. Per capita income in Suriname in contrast lagged far behind, with estimates ranging from just over $\$ 700 \mathrm{GDP}$ to $\$ 1,700 \mathrm{GNI}$ by the year $2000 .^{9}$ Looking back, it comes as no surprise that due to discrepancies in scale and economic development 'reciprocal assistance' remained an illusion.

The first move towards a programme for development aid was the establishment, in 1947, of a 'Welfare Fund' for Suriname. Initially this fund was directed by the Dutch Governor in close cooperation with the ministry in The Hague, yet as of 1951 the management was conferred to a newly established Suriname Planning Bureau working directly under the local government. Up until 1954 the Fund would invest an annual 8 million Dutch guilders in Suriname, adjusted for inflation some 125 contemporary euros 


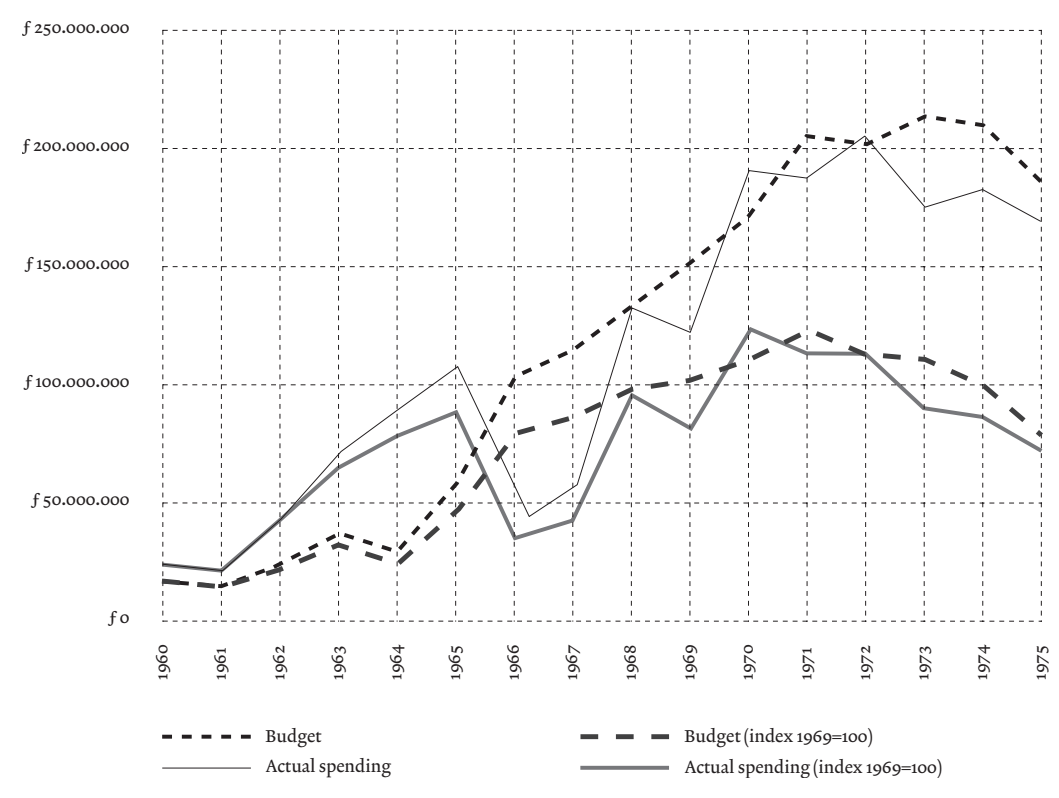

Graph 1. Government budget forecast and actual spending on Surinamese and Antillean Affairs, 1960-1975 (Dutch guilders).

Source: Rijksbegrotingen, 1960-1975. Algemene Rekeningen, 196o-1975 (MinFin).

per capita each year, no inconsequential sum and a start which would set the tone for decades to come. A second constant factor also emerged: constant bickering and Dutch irritation with presumed Surinamese incompetence and ever-rising financial demands versus Surinamese irritation with presumed Dutch arrogance, stinginess and self-interest. Thus as early as 1951, politician M.A. Karamat Ali accused the Dutch of stimulating the reconstruction of Europe rather than the development of Suriname through the Welfare Fund. Minister L. Götzen replied indignantly, squarely refuting any self-interest, emphasising that Suriname should actually be grateful for the aid and the opportunity provided to export part of its produce to the metropolis. ${ }^{10}$ Such arguments never ceased between the partners within - and subsequently outside of - the Kingdom during the half century since this meeting in Paramaribo.

Between 1954 and 1975 the Dutch budget allocated for the Caribbean parts of the Kingdom increased significantly, mainly due to a stepping up of development aid (graph 1). During the fifties aid was reserved for Suriname, but since 1960 the Antilles also received substantial support. Between 1960 and 1975 the total budget for Kingdom relations - 90 to 95 per cent of this was allocated for 'reciprocal assistance' - increased tenfold to 


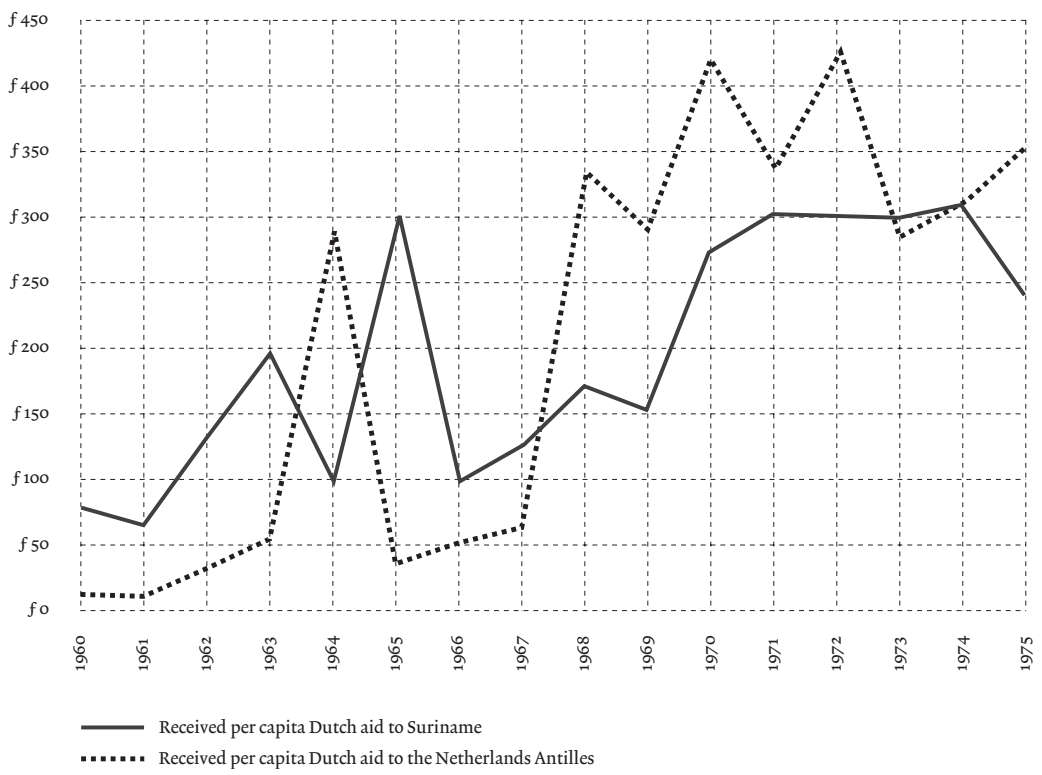

Graph 2. Received per capita Dutch aid to Suriname and the Netherlands Antilles, 1960-1975 (Dutch guilders, unadjusted).

Source: Rijksbegrotingen, 1960-1975. Algemene Rekeningen, 1960-1975 (MinFin).

over 200 million Dutch guilders. ${ }^{11}$ With the exception of the first half of the 1960 s, spending actually lagged behind the allocations made, suggesting a willingness to invest in development frustrated by insufficient outlets. Adjusted for inflation, there was a substantial increase in the period from 1964 to 1971 , followed by a slight decrease, particularly discernable during the period of the Joop den Uyl cabinet. This is remarkable as his administration is routinely associated with overspending and the 'golden handshake' to Suriname.

During the years 1960-1975, just over one billion Dutch guilders were invested by the Dutch state in Suriname as against 900 million guilders in the Antilles. This difference may mainly be attributed to the fact that the islands only started to benefit from aid in the $1960 s$. Per capita aid, both budgeted and actually spent, was higher for Suriname up until 1965. Afterwards the Antilleans became the more privileged (graph 2). This is the more remarkable as per capita income on the islands was more than double the Surinamese figure.

The consistent increase in aid was a result of two developments in Dutch politics. ${ }^{12}$ First, the very idea of development aid became generally accepted in Dutch society and politics. By 1970, the overall budget was targeted at 
the relatively high proportion of one per cent of GDP, and would afterwards be fixed at 0.7 per cent. With the permanent increase of the total national budget, the budget for aid increased accordingly. A specific concern for the Caribbean parts of the Kingdom - 'our own Third World' - implied an ever-rising budget. In the mid-196os, the share of Suriname and the Antilles in the total aid budget was set at 25 per cent, a proportion which was curtailed afterwards as the total aid budget continued growing, but still stood at 17.5 per cent in $1975 .{ }^{13}$

The second factor behind the consistent rise of aid testifies to the growing interrelatedness of the various parts of the Kingdom. This was not only reflected in a more general awareness in the Netherlands of discrepancies in prosperity, but also in the realisation that economic malaise in Suriname and the Antilles could easily backfire on the metropolis. At the time, the primary concern was about new disturbances in the Caribbean. Before long the repercussions of this malaise in the Caribbean would be felt in the Netherlands in the form of mass migration.

All of this would become apparent in the wake of the revolt on Curaçao in May 1969. Politicians in The Hague thought of development aid as a vital instrument to stimulate the economy and thus lower unemployment figures, which were high throughout the Dutch Caribbean and which had been among the major factors behind the Curaçao revolt. Deliberations within Dutch cabinet on the budget for 1970 disclosed a consensus for the use of aid to address the problems of unemployment, along with the necessity to temporarily quell deficits in the Antillean and Surinamese budget. Of course Minister Joop Bakker, responsible for Surinamese and Antillean Affairs, informed parliament that this was 'in principle unjustified and therefore undesirable'. Yet the need for monetary transfers to this end on a temporary basis was evident. ${ }^{14}$

The 1969 revolt and its aftermath reinforced the willingness to make substantial aid available, also as an investment in the preparations for the transfer of sovereignty, which now became a top priority in The Hague's Caribbean policy. Thus, development aid became an instrument on the path towards 'full' decolonisation, at least from a Dutch perspective. Without necessarily subscribing to this view Antillean and Surinamese politicians were happy to be at the receiving end of this rationale. Inevitably, growing Dutch aid also served to stimulate clientelism, already prevalent in the political systems of these small societies.

During the hectic two years of the transfer of sovereignty to Suriname, the den Uyl cabinet certainly had few qualms about using development aid as an instrument in furthering its goals. As minister Jan Pronk told his more cautious colleague 'Gaius' de Gaay Fortman, aid was 'one of the few political levers available to the Netherlands to further independence'. The cabinet indeed decided to promise Suriname higher levels of aid after the transfer of sovereignty. There were continuous pledges of a 'special rela- 
tionship' after independence and the 21 May 1974 bilateral protocol explicitly acknowledged that the Dutch would 'maintain a special responsibility for the development of Suriname' after independence. Internally, the Dutch cabinet was aware that this would imply substantial concessions. As premier Joop den Uyl remarked, there was ample room for blackmail, the more so as the Surinamese government was well aware of the Dutch hurry to get it over and done with. ${ }^{15}$

Initially, the Dutch tried to reach a compromise at some 1 billion guilders, but Surinamese demands went far beyond that. By March 1975 the parties were still widely divergent, even though the Dutch had already doubled their offer. Dutch demands for joint decision making in the spending of the aid were rejected as 'paternalistic'. Meanwhile the Arron cabinet worked to cleverly pressurise the Dutch. While the den Uyl cabinet used the aid as an instrument to help reconcile the Hindustani opposition with the very idea of independence, the Surinamese government repeatedly deliberated with its national rivals on methods to increase the pressure on the Dutch. Long rounds of negotiations were fuelled by accusations of Dutch stinginess and the need to repay for colonialism and slavery. In a sense, then, the final settlement of just over 3.5 billion guilders - roughly 10,0oo guilders per capita, which adjusted to inflation equates to approximately 10 ,ooo contemporary euros per capita ${ }^{16}$ - must have felt somewhat redemptive to the Dutch progressive and guilt-conscious politicians at the other end of the table. 'We were softies', as Pronk later remarked, 'but softies out of genuine political conviction. ${ }^{17}$

Thus a 'golden handshake' was agreed upon in June 1975 with the conclusion of the 'Treaty on Development Cooperation between the Netherlands and Suriname. ${ }^{18}$ The purpose of the treaty was 'to enable Suriname to take development into its own hands in the shortest possible term'. Maximum cooperation was essential to diminish the differences in prosperity between the two countries and to stimulate economic growth, a fair distribution of wealth and the economic resilience of Suriname. Giving in to Dutch pressure on that issue, Suriname agreed to give priority to Dutch goods and services over supplies from elsewhere. The aid was intended to be spent in ten to fifteen years, after which a new treaty would be concluded. Of fundamental importance for contemporary discussions on the future of Dutch-Surinamese relations was the final clause, which stated that 'The Netherlands is prepared to continue granting development aid to Suriname after the completion of [the present] Surinamese development programme'. To this end, eventually preparations would have to be made in bilateral deliberations.

Occasional criticism on the volume and the effects of the development aid had already been voiced prior to negotiations. In 1971, the official advisory council on development cooperation to the Dutch government (Nationale Advies Raad voor Ontwikkelingssamenwerking, NAR) concluded 
that the Dutch aid provided to Suriname and the Antilles was 'exorbitant' and only stimulated long-term dependency. In vain the council had pleaded for a freezing of the aid. Recurrent themes are visible in this criticism voiced by NAR and occasionally by others in the early-1970s. Comparisons with the far lower levels of aid given to the former colony of Indonesia were popular, as was the observation that per capita income was enormously higher in the Caribbean territories than in Indonesia and actually the entire Third World. The aid was said to be far in excess of the absorbing capacity of the receiving economies and to serve as a disincentive for local governments to save, invest and budget prudently. Aid, so the argument ran, had the contrary effect of stimulating state consumption which through the channels of clientelism was spent on an ever-expanding, unproductive and inefficient civil service.

That such criticism had little noticeable effect on policy making may be evident from the above summary of the Dutch-Surinamese independence negotiations. During the debates within Dutch parliament there was no serious objection against the volume of aid agreed upon. Only later, as the bilateral relations deteriorated and - whether or not as a consequence of this - the expected success of the aid treaty proved to be a disillusion, criticism mounted. To be sure, Surinamese spokesmen affirmed that the volume of aid had been too little if compared to the historical guilt and the responsibility that the Dutch had assumed during three centuries of colonial rule. Looking back more than twenty-five years later, Henck Arron, the Surinamese Prime Minister at the time, still spoke of 'a good treaty' and a 'fair share' for Suriname. In fact, he said, the Dutch 'came away with a bargain'. More than anything else, this is a position which lends itself to moralistic rather than to economic debate. One is reminded of den Uyl's frustrated remark during the negotiations, that from the Surinamese perspective any amount of aid was 'a pittance'. ${ }^{19}$

Dutch criticism considered the amount of aid to be exorbitant and detrimental, only contributing to unproductive government consumption and clientelism and making the colony more rather than less dependent on aid, and thus on the Netherlands. The very fact that such concerns were voiced from time to time in Dutch cabinet meetings only underlines that aid had been used as a lever to smooth the transfer of sovereignty. As one top Dutch official remarked cynically in retrospect: 'Everything was fine with den Uyl and Pronk. Their reaction was: "Let it pass, otherwise we ourselves will be badly represented in future history books.",20

In practice, the Arron cabinet began spending the easy money, both to 'start working on our future' and to demonstrate its rank and file that there were indeed perks to independence. As the years went by, the acute awareness that not spending aid equalled letting inflation eat away the real value of the dowry would further stimulate spending. Tragically, at the same time the influx of Dutch development aid in itself added to spiralling infla- 
tion. A major obstacle resulting from the 1975 treaty proved to be that the parties had failed to develop a coherent development programme. All projects were to be approved of by a bilateral committee which thus had enormous power, although being fully dependent on the backing of both governments it soon became highly politicised. In retrospect one cannot escape the conclusion that the whole structure devised for development 'cooperation' echoed the earlier fictitious logic of 'reciprocal assistance'. Apparently both 1975 cabinets had subscribed to the view that Suriname could only embark on a path towards real economic development in an exclusively bilateral relationship. Thus the transfer of sovereignty remained by definition ambivalent and lacking in confidence.

\section{Aid to the Antilles and Aruba since 1975: Structural or Finite?}

With the Caribbean component of the Kingdom scaled down to the Antilles after 1975, The Hague's policy continued to hover between a more or less ambivalent attempt to distance itself while at the same time being guided by the moral conviction that the Netherlands had an historical obligation to fulfil. With aid paradoxically being an instrument towards full decolonisation as well as an ethical imperative, the tendency was towards more commitment and more direct engagement with the challenges of Caribbean development. In this context critical assessments of the amounts and effects of aid were not particularly applauded, let alone translated into more restrictive policies.

All of this was to change in the 1990s: with the acknowledgement that pulling out of the region was no realistic option, the Dutch reformulated their Caribbean policies. In September 2002, as a new right-wing government under Christian democrat Jan Peter Balkenende was embarking on what would be a very short term in office, the website of the Ministry of the Interior and Kingdom Relations still presented the information drawn up by the preceding coalition, and was never updated. The very opening lines under the heading 'Aruba and the Netherlands Antilles' disclosed a telling insight into the priorities and hopes of the Dutch. 'The Kingdom of the Netherlands consists of three separate countries: the Netherlands, Aruba and the Netherlands Antilles. The Netherlands provides financial support to Aruba and the Netherlands Antilles in order to develop their economy and to improve the quality of public administration of the overseas partners in the Kingdom. An agreement has been concluded with Aruba regarding a gradual ending of the development relation. In ten years time Aruba will have to stand on its own two feet financially. The policy towards the Netherlands Antilles is directed mainly at the recovery of the Antillean economy and the modernisation of development aid and constitutional relations. Cooperation with both countries centres around the enforcement 
of the rule of law, the quality of administration (good governance), sustainable economic development (therefore within the limits set by the environment) and education.' By February 2003, after the early fall of the first Balkenende cabinet and a new round of elections, the same information was still on the government website. ${ }^{21}$

What strikes the reader is not only the immediate emphasis on economic relations but equally the determined tone of these opening lines: the Caribbean parts of the Kingdom will have to stand on their own two feet, the sooner the better. After all, aid is never permanent. This policy statement, anything but a new idea, echoed expectations nurtured ever since the beginnings of Dutch development aid to the Caribbean half a century ago. Yet prior to the 1990s, this had never achieved top priority. The explanation for this new hard line can be found in the prolonged economic crisis on Curaçao combined with the perceived lack of good governance and the ever increasing emigration problem. The Dutch are now insisting that these problems should be faced head on if the Antilles and Aruba are to remain within the Kingdom.

What about the figures? With the independence of Suriname, development aid within the Kingdom was only directed at the Antilles and thus reduced significantly. But before long the allocated budget started to increase again, from some 100 million Dutch guilders in 1976 to 250 million in the mid-1980s and oscillating around 300 million guilders - over 135,00o euros - in the 1990s. Up until the present the budget actually realised, presents a rather irregular pattern on the graph of the allocated budget. Since 1998 the realised budget seems to show a remarkable growth which, however, is due to a series of unique and presumably one-time only interventions. ${ }^{22}$ Adjusted for inflation there is a spectacular increase in aid in the second half of the 1970s, followed by irregular oscillations up until the mid-1990s, followed by another, possibly not structural increase (graph 3). Not counting incidental extra expenditures, per capita aid stood at 870 guilders in 1988-2002, three times the amount allocated in 1976. Including these extra expenditures, per capita aid in the same period would be roughly 1200 guilders, thus a four-fold increase when compared to 1976. Yet adjusted for inflation, real increase was limited to the period up until 1980 and the years after 1997. All in all, real Dutch aid around the turn of the century may thus be set at some $€ 500$ per capita.

The so-called golden handshake offered to Suriname on its way to independence has regularly been criticised. Surinamese have often complained that the 3.5 billion guilders should have been indexed to compensate for inflation, a criticism ever more relevant as a considerable proportion of the dowry has still not been allocated; as it is, the real value of this remaining sum now stands at only half the original amount and continues to decrease. In the Netherlands, the 3.5 billion guilders has often been censured as excessive. In this context it is instructive to compare the subsequent aid rela- 


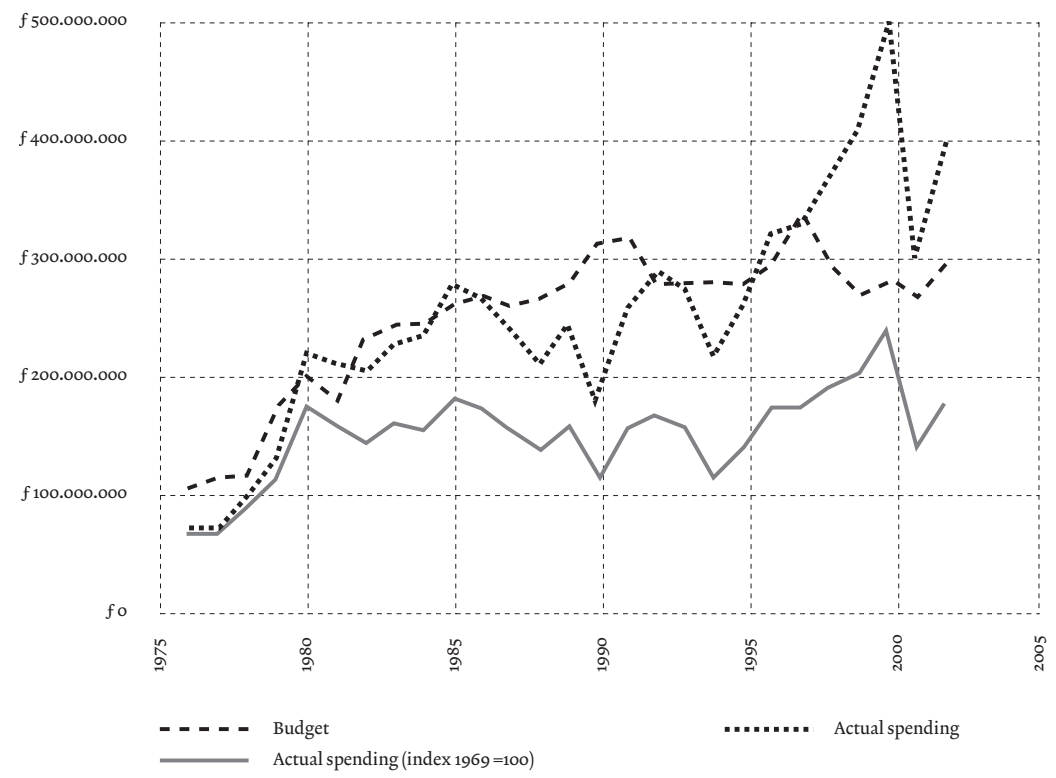

Graph 3. Government budget forecast and actual spending on Antillean (and Aruban) Affairs, 1975-2002 (Dutch guilders*).

Source: Rijksbegrotingen, 1975-2002. Algemene Rekeningen, 1975-2002 (MinFin).

* 1 euro $=2.2$ Dutch guilders

tions within the transatlantic Kingdom with the post-colonial aid relation. Due to both political and economic factors, the Surinamese dowry was not consumed in ten to fifteen years as expected, not even in twenty-five: in 200o, still over one billion guilders remained in the Dutch treasury. Thus in the last quarter of the twentieth century the Dutch allocated less than 2.5 billion guilders to Suriname. In the same period The Hague's aid to the Antilles and Aruba netted some 4.5 billion guilders. Per capita, the Antilleans and Arubans received three times as much aid as the inhabitants of the considerably poorer Republic of Suriname.

In other words, for the Dutch, the costs involved in maintaining the constitutional relations with the Caribbean islands were considerably higher than the amounts earmarked and subsequently allocated to help Suriname towards its independence. A cynic might remark that the 'progressive' den Uyl cabinet mainly favoured the Dutch tax payer by leading Suriname towards its 'destiny' of sovereignty. Conversely, the Antilleans and Arubans clearly benefited from their refusal to follow this lead. That this heightened aid dependency in the Antilles is probably no more than scant consolation in Suriname. ${ }^{23}$

On closer inspection, the financial burden upon the Dutch treasury of 
remaining a transatlantic Kingdom is underestimated in the above figures, as these are all based on the budget of the immediately responsible administrative body only. ${ }^{24}$ Additional costs are concealed in the budgets of other ministries such as Defence (costs of the Dutch military presence on the islands, estimated at 50 to 95 million guilders per year in the late 1990s), Education, Culture and Sciences (scholarships and other costs of Caribbean students studying in the Netherlands) and Foreign Affairs (Dutch embassies also represent the Caribbean parts of the Kingdom). Increasingly there are the costs in terms of social welfare and other expenses related to the Antillean exodus to the Netherlands in the 1990 .

To give a balanced view, one also needs to take into account the economic advantages of the transatlantic link. There are some tangible advantages on a micro-level, ranging from opportunities and employment for Dutch firms and civil servants both in the metropolis and on the islands, to the contribution of the more successful Antillean and Aruban migrants to the metropolitan economy. Yet it remains evident that in economic terms, in spite of idle hopes of 'reciprocity' expressed in the Charter, assistance has remained a one-way affair over the past half century. The Caribbean has never been the window of opportunity sought for by the Dutch - neither in the times of slavery and their aftermath nor in the twentieth century. And this is unlikely to change.

So economic support has remained non-reciprocal. Is that a problem? One would think so on hearing Dutch complaints, yet in fact this spending is not a significant drain on the Dutch treasury. Whereas these funds are of evident importance to the Caribbean countries and their citizens, to the individual Dutch tax payer this expenditure has always been negligible. So this is not the real issue. Far more important is the question of whether the aid really helps. This brings us back to the opening of the chapter and the conclusion drawn that the remaining Dutch Caribbean islands belong to a privileged group of non-sovereign territories with comparatively high standards of living, whilst at the same time being extremely dependent and vulnerable economies with, at least in the case of Curaçao, very high unemployment figures. Clearly the aid brings mixed results.

How has aid really worked in this respect? There are solid grounds for doubt indeed. While Dutch aid helped to improve living standards, it failed to stimulate self-reliance and indeed led to aid dependency. The post-independence economic development of Suriname is a case in point: no country received as much per capita aid as a dowry, yet as soon as the easy money provided by the Dutch was discontinued, the main players in Surinamese economics proved to be heavily reliant on these flows and the multifaceted dependence which went with it.

The same argument is used to explain the prolonged economic and budgetary crisis of Curaçao. For decades, so the argument runs, Dutch aid has kept local policy makers from making the necessary harsh choices such as 
tightening the exorbitant share of government in public spending and investing in more productive sectors. Moreover, an empirically substantiated awareness that in the end the Dutch always offer assistance, albeit on the condition that their procedures will be adopted, has bred a passive mentality. Hence, the argument closes, aid has deepened dependence rather than producing genuine development. The only success story is Aruba, where aid helped the economy through the mid-1980s slump and might even soon become marginal, if not superfluous - as it is optimistically believed both in Oranjestad and in The Hague. ${ }^{25}$

The contemporary orthodoxy as expressed time and again by Dutch policy makers at the closing of the century has been simple. Less government with more good governance. The volume of financial assistance provided is high, thus should certainly not be increased, and will actually need to be lowered and eventually discontinued altogether. Meanwhile, aid should be channelled through long-term programmes rather than all kinds of shorttime projects which have no structural effect and which entail too high an involvement by Dutch administrators. And, of course, aid cannot be provided to compensate for deficits in the regular government budget. ${ }^{26}$ What is surprising is that his policy presented as a new, tougher line had already been preached so many times previously, as a short review of the preceding debates may illustrate.

As early as 1977 Minister for Antillean Affairs de Gaay Fortman declared 'that the dependence of the Antilles on the Netherlands has deepened by the way aid has been provided. I think that in the past there has been too much leniency with the approbation of projects and things the [Antilles] should have taken upon themselves. I underline again that I have moved to another and tougher line, precisely because I do not want this dependency which I regard as harmful to the Antilles.' Two years later his successor Fons van der Stee also criticised the workings of development aid, which in his opinion blurred rather than addressed the real problems. Another course should be steered, he maintained, one of diversification of the Antillean economy with the purpose of eventually rendering Dutch aid superfluous. ${ }^{27}$

In 1978 the NAR had published a new advice, this time focusing on aid to the Antilles. Harsh conclusions were drawn. The results were 'disillusioning', not simply because of the problems inherent in small economies, but equally due to the way aid had been extended, namely in the form of projects often formulated to suit incoherent demands motivated by domestic Antillean politics. The Dutch stance, so the NAR concluded, had been too lenient and devoid of any long-term perspective. One year later, in 1979, the 'Gemengde Commissie van Deskundigen' (Bilateral Commission of Experts) concurred with many of these findings, and actually concluded prolongation of this policy to be too 'damaging' to even consider. Instead the commission pleaded for financial reconstruction, a stepping up of the An- 
tillean contribution to economic development programmes and a gradual transition from project-related aid to long-term programmes. The 'Gemengde Commissie', incidentally, also remarked that Dutch aid projects often reflected Dutch rather than Antillean priorities, and pointed out the paradox that intensifying aid relations in practice created more dependency on the metropolis. ${ }^{28}$

Despite such advice and the stern words spoken by the responsible ministers, not much was heard of actual plans to improve development relations. Van der Stee's successor Jan de Koning continued to lecture his colleagues on the islands that the prime responsibility for development lay not in The Hague but rather with themselves. Yet there was no transition towards programme aid, and economic recession in both the Antilles and Aruba during the 1980 s kept the Dutch from cutting aid, thus sparing their Caribbean counterparts the obligation to tighten their budgets. In fact, de Koning is still remembered fondly by island politicians for his clemency. His highest civil servant in this period, KabNa director Frits Palm, remembered: 'If the islands requested the same thing for three consecutive years, he concluded that they were really in need of this.' In his opinion, de Koning thus helped his Caribbean counterparts on the path to becoming 'heavily spoiled children'. ${ }^{29}$

Upon assuming his tasks as Minister for Antillean and Aruban Affairs, de Koning's successor Ernst Hirsch Ballin not only announced that the Dutch had finally parted with their stated policy of transferring sovereignty to the islands. Likewise, and in a sense as a direct consequence, he declared that development relations should be fundamentally redressed. Hirsch Ballin too concluded that aid had deepened dependence rather than stimulated self-reliance. In parliament he criticised the use of Dutch aid to finance what should have been current expenses of the Caribbean governments. As had been done over the previous fifteen years, he indicated once more that a transition should be made towards programme led aid. Relatively new was the consistent emphasis on investing in good governance as the condition necessary for balanced development. ${ }^{30}$

The policy formulated by Hirsch Ballin would be further elaborated by his successors Joris Voorhoeve and Gijs de Vries. During their successive terms in office new studies were published which, while corroborating earlier analyses, aimed at actually implementing the directives formulated over time. In the mid-199os the economic situation in the Antilles, including the finances of the central government, was dire which along with other problems resulted in mass migration to the Netherlands. Reflecting on his first official visit to the islands, Voorhoeve felt an alarming lack of political commitment and a tendency to "let the Dutch pay the bills, now and in the future'. ${ }^{1}$

One of his first initiatives was to appoint, with the Antilles and Aruba, a trilateral commission to establish the depth of the crisis. This resulted in 
the 1996 report published under the telling title 'Debt or Future'. The commission concluded that the debt of the Antillean government was high - eighty per cent of GDP - and still rising. The Aruban debt was only half that amount, but still too high. In addition, both governments had considerable outstanding financial liabilities connected to guarantees on investments. Budget control was poor, economic policies insufficiently articulated, particularly for the Antilles. The state apparatus was too extensive, costly and inefficient. Unlike the more successful Aruba, the Antilles had unduly stuck to protectionism, thus aggravating the crisis. Particularly cutting was the comment that 'there is a need for the political awareness that norms of good economic policy cannot be ignored without punishment'. Moreover, at the level of the Kingdom an open and frank dialogue on development policy was dearly missed. In its recommendations, the commission hammered home the need for good governance, including budget control, liberalisation and long-term planning. ${ }^{32}$

The Dutch reaction to the report was predictable: a tough line was the only way out. The Antillean government too saw advantages in calling upon the International Monetary Fund (IMF). Both governments thus agreed to develop a trajectory for restructuring the Antillean public finance and its state bureaucracy in close cooperation with the IMF. External monitoring by the IMF became a feature of this field of relations within the Kingdom, even if sometimes Antilleans would complain this was not in accordance with the special character of the relationship as defined in the Charter. To be sure, regular aid relations would continue without the involvement of the IMF.

In the process, new studies were made and reports written, officially at the behest of the Kingdom government but certainly under strong Dutch pressure. During Voorhoeve's term in office, two commissions produced reports ultimately leading to the establishment of development banks in the Antilles and Aruba. ${ }^{33}$ These banks would have to manage Dutch aid on the basis of long-term development programmes, in the process breaking with the much criticised micro-management formerly exercised by Dutch public servants. By then, this approach had become the new orthodoxy and was officially applauded on both sides of the Atlantic. Yet the difficult job of financial restructuring remained, and for the Antilles this is still an ongoing process. In contrast to the booming Aruba, the Antillean economy had experienced consecutive - if now finally decreasing - negative growth rates ever since 1997.

In Toekomst in samenwerking, the policy report published early in his term as State Secretary for Antillean and Aruban Affairs, Gijs de Vries reiterated Dutch confidence in a policy line which entails the shifting of final responsibility for economic development - in particular the management of aid to the Caribbean countries, more specifically to the new development banks, at the same time hammering home the need for good governance, 
structural reform of the Antillean economy and a more cautious financial planning by both Caribbean governments. ${ }^{34}$ Much of this was not new, except for the rather rigid imposition of budgetary discipline through the IMF rather than in direct bilateral negotiations. The as yet inconclusive and thus frustrating ending of the IMF trajectory has been recounted above. ${ }^{35}$

At the end of his term in office in 2002, de Vries publicly affirmed that much progress had been made in the preceding years. Aid was finally structured in long-term programmes covering four fields: sustainable development, education, quality of governance and the enforcement of law. Parts of the economy had been liberalised, new tax systems were being developed, the development banks would soon function, etc. Yet in his agenda for the immediate future, the list of priorities looked much as it had done for many years. There remained, he claimed, need for a restructuring of the still huge Antillean debt and for more rigorous financial planning, for further privatisation and for a cutting down of the civil service - still a 'financial milk cow' and used to 'help political friends to jobs' - for 'modernising aid' and for fighting political mismanagement. Again he insisted that no budgetary assistance to the Antillean government should be warranted without IMF approval..$^{36}$

Thus after de Vries' four year term, along with the eight years of his predecessors who gave financial restructuring an equally high priority, the picture for the Antilles remains worrisome. There have been substantial achievements, particularly in the reduction of the large and often inefficient civil service and hence a considerable narrowing of the government's budget deficit and debt. Still the Antillean government has had great difficulty in meeting all IMF demands, and consequently Dutch assistance to their adjustment programme has remained at a level falling below Antillean expectations. Despite this firm or, as some would see it, rigid stance, the amount of financial assistance actually provided to the Antilles through the regular channels was upheld and even increased beyond the allocated budgets, certainly a level of support no non-sovereign country could dream of. The same applies to Aruba, which achieved far more in economic performance and budget control, and continued to receive aid with fewer strings attached as a result.

In Curaçao, Dutch policy has provoked much criticism and even bitterness. For a start, the Antillean government frequently affirms that while Dutch aid is not only welcome but even crucial in this period, its current contribution to the Antillean economy amounts to only 10 per cent of the total government budget of the islands and only 3.5 per cent of its GDP - far less than is often suggested. Next, there is the criticism that the Dutch tend to blame all short-comings in the aid relation to Antillean mismanagement, when in the Antillean perspective the Dutch Ministry was often patronising and unpredictable. ${ }^{37}$ The Dutch confidence from earlier decades that simply sending aid would solve local problems has all but disappeared 
and so has the willingness to confer aid without strict conditions on local restructuring and liberalisation. It may be clear that the Dutch government has continued to grant large amounts of state money to its Caribbean partners, even as relations soured at the closing of the century. Yet obviously the Dutch refuse to accept the claim that the Charter implies unconditional support.

This is not likely to change. In September 2002 the new right-wing cabinet presented its first national budget. The budget included a continuation of the relatively high financial allocations to Antillean and Aruban affairs, put at a near $€ 138$ million - a huge amount yet only a one-thousand share of the entire Dutch budget. Once more, the accompanying texts speak of the need to remain on the IMF track, of a further restructuring of public finances, and of a tough Dutch stance regarding good governance particularly, as stated in the parliamentary year opening address read by the Queen, 'as long as criminality remains high'. There are no indications whatsoever of an inclination to soften the conditions set for additional aid. Indeed, The Hague's contemporary politicians seem firmly against following in the footsteps of previous generations attuned to extending development aid on terms deemed too soft in retrospect. ${ }^{38}$

It is a sobering conclusion that much of what was considered as clear policy guidelines for aid and development, by the early twenty-first century had already been formulated and rehashed time and again in the preceding quarter of a century. It is disillusioning to find that after a dozen years of rigidly pressing these points, the present situation leaves much to be desired. Yet perhaps more worrying is the question of whether concepts such as 'self-reliance' and a 'satisfactory' standard of living are feasible objectives for these territories to begin with. By definition prosperity is a relative concept. Expectations for the attainment of a stable standard of living on the islands on a par with the Netherlands cannot be held onto with much confidence. The same applies to the more cautious formulation of a 'satisfactory' standard of living. The bottom line is that precisely because of the ever-increasing integration of the various parts of the Kingdom, definitions of 'satisfactory' have become ever more firmly tied to Dutch rather than to regional standards, as The Hague originally hoped. Hence the very idea of self-reliance at a satisfactory level remains a receding horizon. Not completely illusory perhaps, and most certainly pursuable as the contemporary Aruban success story indicates. Yet it remains unwise to nurture rosy expectations of the bridging of the present contrasts in prosperity and the propensity in the Dutch Caribbean islands to switch to another frame of reference than the one provided by the metropolitan core of the Kingdom.

Sobering too is the realisation that the shifting of responsibility to these Caribbean territories is almost by definition at odds with their small scale, which implies a fragile economic basis and an inescapable scarcity of both natural and human resources. Former Antillean Prime Minister Miguel 
Pourier remarked pointedly that 'We haven given part of our autonomy back through the workings of development aid'. ${ }^{39}$ One wonders whether it could have been different, with such high expectations to be fulfilled. Without doubt these questions are not new, although they tend to be forgotten among politicians and bureaucrats, with their hopes of 'self-reliance at satisfactory levels'.

\section{A Comparative Perspective}

There is no doubt that the non-sovereign Caribbean receives far more aid than any other part of the region, and indeed at a level exceeding that of any other developing country in the world. ${ }^{40}$ There are, however, considerable differences within the group of non-sovereign Caribbean countries. Figures are notoriously difficult to find and lend themselves to different interpretations. Yet we will make an attempt to sketch at least the broad outlines. It should be stated in advance that some significant costs of the maintenance of a Caribbean extension to a metropolitan state are left out of the equation here. This applies first and foremost to the, particularly in the case of the United States, considerable costs of the military apparatus. It also applies to the costs involved in migration to the metropolis and to less appreciable costs such as diplomatic representation of the dependent territories. It goes without saying that such costs also have their benefits to the metropolis, ranging from geopolitical interest to the contribution migrants make to metropolitan economies.

Above we have calculated that Dutch aid to the Antilles and Aruba amounts to some $€ 500$ per capita at the turn of the century. Dutch politicians have frequently stated - and often complained - that no population receives financial aid at a higher level than is found on the Antilles and Aruba. In reality, as we will demonstrate below, both France and the United States have consistently been spending more per capita on their respective territories in the Caribbean. This reflects their long-standing strategic wish to maintain a strong presence in the region.

Throughout the post-War period, Paris has made few qualms about its ultimate responsibility for standards of living in the départements d'outremer. There is a price to pay for maintaining a presence all over the world and thus upholding some of the French grandeur. The overseas populations are citoyens, citizens with the same rights as those in the metropolis, and since these decisions were made (shortly after the ending of World War II), a substantial cut in transfers has never seriously been considered. To the contrary, new aid programmes are frequently initiated, often under strong pressure from the overseas departments themselves. To quote one recent example: in 2002 the French government decided to allow students from the overseas territories studying in France - at the same low cost as metro- 
politan students - two free return flights to their homes per year. ${ }^{41}$

In addition, and of growing importance, is the aid provided by the European Union. It is in this field that the départements d'outre-mer, and in fact metropolitan France as well, enjoy a major advantage. European development aid is extended to the former European colonies in Africa, the Caribbean and the Pacific (the ACP countries), as well as to the non-sovereign Overseas Countries and Territories (OCTs). Per capita, these OCTs - including the Antilles and Aruba and the British Overseas Territories - receive far more aid than the ACP countries do. This aid is provided under the European Development Fund destined for non-European developing countries and territories..$^{42}$ The French Dom in turn receive far more aid from Brussels than any of the OCTs, which after all are not fully part of Europe. The départements d'outre-mer obtain European funding mainly through the European Structural Funds destined for lesser developed 'ultra-peripheral' regions within Europe; per capita income in the Doм is less than 75 per cent of the European Union's average, hence they qualify for generous funding by Brussels. In a sense then, every member of the European Union helps to subsidise France's continuing overseas presence: for 2001, the Eu made available to the Caribbean Dom an amount of $€ 265$ million, on average some $€ 270$ per capita. If one adds to this the direct per capita transfers from Paris - ranging from approximately $€_{2,650}$ to $€_{3,550}$ annually - total per capita transfers to the French Caribbean range from just over $€ 2,900$ for Guadeloupe to $€_{3,740}$ for Guyane and just over $€_{3}, 800$ for Martinique, with the European contribution ranging from nearly seven to ten per cent of the total. These transfers, as may be clear, are unrivalled in the Caribbean, and possibly in the world, with the exception of the fourth French Doм, Réunion in the Indian Ocean. ${ }^{43}$

Of course, not all European or French metropolitan money directly benefits the local populations. For example, some of the euros invested in Guyane find their way to the enormous Kourou platform, base of the European Ariane space programme and the infrastructure supporting it. The base offers some local employment, but basically it serves French and European strategic interests. Likewise, the costly French military and police presence in the region not only assures public order in the departments but also serves a metropolitan strategic interest. Yet arguably the level of public services in fields such as medical care, education, public housing and welfare support is higher in the départements d'outre-mer than anywhere else in the Caribbean. French and, through France, European support in upholding metropolitan standards is crucial in this respect. The French government itself proudly compares per capita income in its DoM to the figures for the neighbouring countries - disclosing wide discrepancies in favour of the departments of course. ${ }^{44}$

Strategic interest has been of paramount importance in Washington's policy for its Caribbean dependencies. Though reliable estimates, let alone 
exact figures, are not available, it is clear that American spending on its military presence on and around the islands is high. Partly inspired by strategic interest was the massive development programme initiated in the $1950 \mathrm{OS}$ for Puerto Rico, Operation Bootstrap. Within two decades, the destitute, primarily agrarian island was transformed into a relatively industrialised economy with far higher per capita incomes than ever before. Yet the success of Puerto Rico as a 'showcase for democracy and capitalism in Latin America' waned in the 1970s. Both unemployment and emigration figures have since remained extremely high, and a larger number of citizens are dependent on state support than anywhere in the United States. The per capita GDP of over $\$ 12$, Ooo is high by Caribbean standards, although lower than anywhere in the continental United States. But here again, metropolitan support is indispensable. In the latter part of the 199os, the annual federal transfers to Puerto Rico reached almost $\$ 10$ billion, or $\$ 2,500$ per capita. A report from the U.s. General Accounting Office providing background for the debate on a possible change of constitutional status projected that with full statehood, federal transfers would have to increase to some $\$ 13$ billion - inspiring Nydia Velázquez, one of the Puerto Rican members of Congress, to characterise the report as a 'kiss of death for statehood'. For the Virgin Islands, estimates of per capita GDP range from $\$ 13$,0oo up to $\$ 19,500$. United States' aid is considerable, in the order of $\$ 1$,ooo per capita. Of course, with only 110,00o inhabitants as against the 3.8 million Puerto Ricans, the aid to these islands remains modest and therefore attracts little attention in Washington. ${ }^{45}$

Following the war, in contrast to the French and the Americans, the British soon set in motion plans to relinquish their hold on their Caribbean dependencies. There was no substantial development aid before the transfer of sovereignty, nor a policy of using aid as a 'reward' for opting for independence. In terms of development aid, the former colonies thus neither lost nor won much with independence. When the decolonisation process came to a halt in 1984, with the formal ending of the pressure to accept independence, the remaining Caribbean territories were receiving modest levels of aid and several still continue to do so. According to British government information, of the six OTs in the Caribbean only Anguilla, Montserrat and the Turks and Caicos Islands still receive development aid, aimed at 'meeting [their] reasonable needs'. The three others have, in official terminology, 'graduated from financial aid'. From the per capita aid figures provided, it is evident that the British level of assistance to the Caribbean оTs is far below that of the French, American and even the Dutch. ${ }^{46}$

British aid is primarily spent on reinforcing good governance, including the 'war on drugs', and on occasional emergency help, such as when Montserrat was all but destroyed by volcanic outbursts since $1995 .{ }^{47}$ The limited direct development aid aims at maximising economic growth and self-sufficiency rather than improving standards of living through welfare or sub- 
stantial investments in medical care and education. ${ }^{48}$ Again, in comparative terms the inhabitants of the British OTs are well-off, with per capita income ranging from some $\$ 7,000$ to an astonishing - but, in view of the skewed income distribution, also elusive - $\$ 24,000$ in the Cayman Islands. ${ }^{49}$

How do these findings compare to Dutch policy? First, of course, the conclusion that no matter what Dutch politicians like to claim, Dutch aid is by no means the highest per capita. In terms of contribution of aid to the local budget, it is appropriate to emphasise that the proportion of Dutch aid in the total GDP and even in the government budget of the islands is moderate, certainly lower than is the case for the French departments and Puerto Rico..$^{50}$ Meanwhile there are substantial differences in the allocation of financial transfers. Most of Dutch aid is indeed development aid, even if the part allocated for defence, mainly in the 'war on drugs', has been steadily rising during the last decade. Unlike the French and the Americans, the Dutch have no tradition of spending large amounts to serve their own strategic interests - simply because they never saw the region as having much (strategic) importance. From a Dutch perspective, the necessity to engage in a costly project such as the coast guard is another infelicitous consequence of its inability to part with its colonial history in the Caribbean. Still, genuine development aid remains the core of the Dutch contribution to the islands. All in all, the conclusion appears to be that when compared to The Hague, Paris (plus Brussels) and Washington spend significantly more per capita on aid and welfare, while London spends clearly less to further the standard of living of its Caribbean populations.

A question of equal importance is whether all of this is of much consequence in the Caribbean territories? Here we are reminded of a dubious record. Even if we bear in mind that in the non-sovereign Caribbean prosperity is very unevenly divided, and that expatriate individuals and enterprises own a disproportionate share of local wealth, there is no doubt that standards of living are higher than in the sovereign countries. Yet it is evident that there is no question of self-reliance. One may cynically conclude that the higher the per capita aid, the higher the dependence on the metropolis. It is obvious that all of this is very much at odds with the neo-liberal policies which have been prevalent since the 1990s. Metropolitan presence and aid seem to have brought relatively high standards of living, but equally extreme dependence and vulnerability. High unemployment figures bear witness to this. So do the equally high emigration rates which, as we will discuss in more detail in the next chapter, testify to the paradox that for the populations of the non-sovereign Caribbean, the awareness that standards of living are much lower elsewhere in the region is of less significance than the realisation that they are much higher in the metropolis.

The next question then becomes whether these discrepancies are likely to be mitigated or disappear altogether. It is difficult to answer this ques- 
tion in the affirmative. The trend for the past decades has rather been for metropolitan standards of living to improve tremendously, leaving the non-sovereign Caribbean increasingly lagging behind, while the record in the sovereign Caribbean has been diverse but points to an even wider division for the majority of people. Most of the non-sovereign Caribbean - perhaps with the exception of the British Overseas Territories and Aruba - is caught in a paradox. Metropolitan support has been indispensable in keeping up the present standards of living, yet at the same time these standards tend to make the territories not only islands of relative affluence in the region, but at the same time economies whose competitive power is steadily decreasing due to relatively high productive costs without concomitant high productivity. The end result of this paradox is a deepening dependence on the metropolis, precisely the opposite of the proclaimed objective of the development aid given over the past decades.

On different accounts, the British Overseas Territories and Aruba seem to present an exception to this rule. The British dependencies have to largely fend for themselves, which has stimulated self-reliance. Yet it should not be overlooked that these are extremely small islands with small populations, and that their success is to a large degree dependent on income derived from offshore financial services. This sector, apart from risking to be swept away by recent American and European legislation anyway, can hardly provide a model for populations and economies of a larger scale. Aruba, with a booming economy, a steadily rising income and population, and hardly any unemployment over the past fifteen years is presently considered a show case. Here, so the argument runs in both Oranjestad and The Hague, development aid has been efficiently used as an indispensable but temporary instrument to overcome a grave crisis and put to work in such a way that self-reliance and a gradual phasing out of aid will soon become feasible. A show case this is indeed, certainly in contrast to Curaçao. Yet one cannot escape the feeling that the official enthusiasm tends to underestimate the inescapable vulnerability of a small island economy fully dependent on a limited number of service industries, of which tourism is number one, with narcotrafficking and money laundering probably also entering the equation.

Having said all this, the observation that those living in the non-sovereign Caribbean do benefit materially from the metropolitan liaison still stands. In a sense, it is rather the former colony than the metropolis which today exploits the post-colonial bond. While there are drawbacks in the sense of low self-reliance, the positive economic significance of metropolitan support ranges from financial transfers to helping to provide an institutional framework which enhances international credibility. Of even greater economic significance perhaps, whether for good or for bad, is the migratory link between the metropolis and Caribbean territory. This will be the subject of the next chapter. 


\section{A Caribbean Exodus}

Migration has characterised Caribbean history and is still central to the lives and awareness of its inhabitants today. ${ }^{1}$ European immigration, the African slave trade and the recruitment of Asian indentured labour accounted for the populating of the region after the indigenous Amerindian inhabitants had been all but annihilated in the wake of the conquista. Upon the abolition of slavery in the mid-nineteenth century, labour migration within the Caribbean and to Central America gained momentum, with Barbadians moving to British Guiana since the 186 os, Jamaicans building the Panama canal at the turn of the century, islanders from all over the Caribbean doing seasonal work at the Cuban and Dominican sugar plantations after World War I, and many being drawn to the oil refineries of Aruba and Curaçao as of the late 1920s. This movement of people within the Caribbean has never stopped. Today, labour migrants from the poorer countries such as Haiti, the Dominican Republic and Jamaica can be found virtually all over the region.

Yet emigration from the Caribbean to the United States and Western Europe has attracted far more attention. Again there is a long history preceding the post-war exodus. All through the colonial period, colonial subjects were brought to the metropolitan centres by their masters. Members of the colonial elites, white and increasingly also coloured, sent their children to be educated in Europe. Today's strong Caribbean presence in the United States has its roots in the early twentieth-century migrations of British West Indians and Cubans to the continent. In fact, prior to World War II, only the migration movements within the Caribbean and to Central America and the United States were of major numerical significance. This would only change in the post-war period, with a short but significant bifurcation of the migration flow from the British West Indies to the United Kingdom up until its ban in 1962, and the ongoing migration to France and the Netherlands.

Focusing on the Dutch Caribbean, an initial observation reveals that these colonies were net receivers of migrants up until World War II. The last shipment of Javanese indentured labourers arrived in Paramaribo in 1938. Prior to the establishment of oil refineries on Aruba and Curaçao, Antilleans had been working as seasonal labourers in Cuba and in Suriname. Once the oil industry took off however, Curazoleños and Arubianos did not need to search for labour opportunities elsewhere, and in fact saw their islands invaded by tens of thousands of migrants from the region, including 
Suriname. Meanwhile, Dutch Caribbean migration to the Netherlands remained insignificant in demographic terms.

At the time of the proclamation of the Charter, in December 1954, no more than 5,000 Surinamese and Dutch Antilleans were living in the Netherlands. By the end of 1975 this number had grown to more than 125,000, the vast majority of which were of Surinamese origin. The immigration wave would reach its peak in the run up to Suriname's independence, inducing feverish consultations on a policy to stem the flow. Not only were immigration numbers considerably higher than deemed opportune in Dutch circles, but they also greatly exceeded previous estimations. This would not be the last miscalculation. By 2000 the Caribbean community in the Netherlands numbered some 435,00o (see table 1).

Roughly two thirds of today's Caribbean Dutch are of Surinamese origin, the remainder are mainly Antilleans from Curaçao. For the Surinamese, this rather spectacular increase is due to continued migration in spite of legal obstacles, as well as to demographic growth. In fact, since independence in 1975 the Surinamese population has grown considerably on the European side of the Atlantic, while showing very little gain on the Caribbean side: in 1975 Suriname had some 375,00o inhabitants, in 2000 almost 420,000, among which however a considerable number, perhaps as many as 40,000, are recent immigrants from Brazil. ${ }^{2}$ Aruban emigration would peak briefly during the mid-1980s crisis, but has since been negligible. Antillean migration to the Netherlands in contrast showed constant if uneven growth throughout the last decades, peaking in the second half of the 1990 . Curaçao is the most affected; its population decreased from nearly 150,000 throughout the 1970 and 1980 s to some 130,00o today.

In contrast to the non-European population of the Dutch East Indies, the inhabitants of the Caribbean colonies traditionally enjoyed the right of abode in the metropolis. This was not altered when the colonies became autonomous partners in the Kingdom in 1954. For Suriname this freedom ended as a result of its independence, allowing however an extension to the right of abode for a further five years. The freedom of movement to and from the Netherlands has always been considered an elementary right in the Caribbean territories. In contrast, Dutch nationals never enjoyed the unrestricted right of abode in Suriname, while the Antilles have only recently relaxed their immigration laws for European Dutch, on 15 March 2001. Should Dutch nationals want to work in the Antilles, they still need to apply for a residence permit. However, a work permit is no longer required. Aruba has so far managed to maintain its hardline immigration policy. ${ }^{3}$

The freedom to follow different migration policies within the Kingdom has been laid down in the Charter. Consequently the Netherlands could have decided, and in fact regularly contemplated, implementing its own restrictive immigration policy. This was discussed most openly under the second 'purple' cabinet of Wim Kok (1998-2002), which for the first time 
Table 1. Surinamese and Antillean/Aruban community in the Netherlands, $1955-2000^{*}$

\begin{tabular}{|c|c|c|c|}
\hline & Surinamese & \multicolumn{2}{|l|}{ Antilleans and Arubans } \\
\hline 1955 & approx.5,ooo & \multicolumn{2}{|l|}{ N.A. } \\
\hline 1960 & approx. 8,ooo & \multicolumn{2}{|l|}{ N.A. } \\
\hline 1965 & 11,611 & \multicolumn{2}{|l|}{ approx.2,500 } \\
\hline 1970 & 28,985 & \multicolumn{2}{|l|}{13,630} \\
\hline 1975 & 104,154 & \multicolumn{2}{|l|}{23,900} \\
\hline 1980 & 177,600 & \multicolumn{2}{|l|}{29,812} \\
\hline 1985 & 181,400 & \multicolumn{2}{|l|}{46,200} \\
\hline 1990 & 219,000 & \multicolumn{2}{|l|}{71,200} \\
\hline 1995 & 280,615 & 86,825 & 179 \\
\hline $\begin{array}{l}{ }^{*} \text { Figu } \\
\text { with o } \\
\text { ** Post } \\
\text { Surina } \\
\text { for bo }\end{array}$ & $\begin{array}{l}308,825[317,294]^{* *} \\
\text { irst-generation immig } \\
\text { wo first-generation par } \\
\text { igures for Dutch citizen } \\
\text { n the Netherlands with } \\
\text { gories is given for } 2000 \text {. }\end{array}$ & $\begin{array}{l}\text { nts and second-generation offspring } \\
\text { ts. } \\
\text { of Surinamese background do not include } \\
\text { nly Surinamese citizenship. The grand total }\end{array}$ & 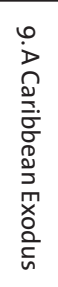 \\
\hline
\end{tabular}

ever seriously considered curbing Caribbean - particularly Curaçaoan - immigration by legal means. The traditional Caribbean argument against the principle of reciprocity was clear. Unrestricted access of the Dutch to their small societies would easily result in an informal metropolitan take-over with serious social repercussions, while the number of Caribbean migrants in the Netherlands would always remain relatively low and therefore of little effect. The Dutch consented with this argument until the signs of a Caribbean exodus became clear. Since, they have repeatedly threatened to mirror the Caribbean restrictions on migration. That this has not yet been put into practice reflects growing Dutch irritation over the imbalance in migration movements, next the realisation that any measures in this field would be extremely difficult to implement, as well as an awareness that such a restriction would imply a major redefinition to the meaning of Kingdom citizenship.

This last factor, of course, is derived straight from the core of the Charter: all inhabitants of the Kingdom, also those of the Antilles and Aruba, enjoy full metropolitan citizenship. With the Charter indicating that mat- 
ters regarding nationality are joint Kingdom affairs, to be dealt with communally, any kind of legal distinction between inhabitants of the Kingdom on either side of the Atlantic would require the cooperation of the Caribbean countries involved. It is unthinkable that Antillean and Aruban concurrence with a restrictive policy will ever be forthcoming. This leaves The Hague little legal room to curb migration. ${ }^{4}$ Added to this, it is very questionable whether any kind of restrictive Dutch immigration policy for its Caribbean territories would be conceivable and enforceable within the present context of European unification. Thus the chapter of Caribbean migration to the Netherlands is anything but closed.

\section{Prelude, 1954-1973}

In 1945, Dutch society was essentially white. The country considered itself overpopulated. Up until 1960, state-sponsored emigration projects would see some 300,ooo Dutch leaving for countries such as Canada, Australia and New Zealand. Paradoxically, an equal number of immigrants landed in the Netherlands. Many of these were in a sense political refugees, fleeing the lost colony of Indonesia. Ethnically, these migrants were partly European, partly Indonesian, and partly of mixed Eurasian origin. Dutch politicians and press, and perhaps also the wider public were concerned about this wave of immigrants possibly unable to adjust to Dutch culture. Yet as it turned out, most of them would soon be successfully integrated and in fact their trajectory in Dutch society would in retrospect be heralded as a model of silent integration. By the early twenty-first century, the number of Dutch with (part) Indonesian backgrounds was over 400,00o yet did not figure anywhere in statistics regarding non-Western immigrant communities in the Netherlands. ${ }^{5}$

Only since 1970 has the Netherlands become a net receiver of migrants. ${ }^{6}$ By 1970, the proportion of non-Western immigrants and their second-generation offspring was estimated at a mere one per cent. Real growth took place since the 1970s, from two per cent in 1975 to some ten per cent today. In the early twenty-first century, over 1.5 of the 16 million people living in the Netherlands are recorded as 'non-Western'. The three largest communities are of Surinamese, Turkish and Moroccan origins; the Antilleans are in a second category. Today the proportion of the 'non-Western' ethnic minorities in the major Dutch cities is around thirty per cent, and among minors just over fifty. A 2003 survey showed that 'non-Western' youth account for over forty per cent of secondary school pupils in the larger cities and even two-thirds in Amsterdam. ${ }^{7}$ Seen from this perspective, it is remarkable that in government, acute concern over the then present 'dangers' posed by post-colonial migrants was voiced as early as the end of the $1940 \mathrm{OS}$.

This concern with Caribbean migration would re-emerge in the $1950 \mathrm{~s}$ 
and in 1958 The Hague began to focus on the expansion of the Surinamese community in the Netherlands, particularly in view of the presumed dangers of marginalisation and criminalisation. It concerned relatively small numbers - at that time an estimated five to six thousand Surinamese were residing in the Netherlands, mainly in the capital. The Prime Minister of the day, the social democrat Willem Drees, would more than once express his unfavourable opinion of these Caribbean immigrants. He would draw attention to the 'peculiar contrast' between the liberal Dutch policies on the one hand and the tight immigration policies of the Kingdom partners on the other, leaving little scope for metropolitans to take up residency overseas. Drees believed that in the event of a revision of the Charter, a restrictive Dutch immigration policy should also be instigated. Yet within cabinet it was generally accepted at the time that it was politically inopportune to introduce legal measures 'to curb the undesirable emigration of Surinamese to the Netherlands'.

Caribbean immigration would also occupy the cabinet under the Christian democratic Prime Minister Louis Beel (1958-1959); the issue was again fuelled by complaints concerning presumed criminal behaviour of Surinamese in the metropolis and by irritation at the restrictive immigration policies overseas. A thorough revision of existing Kingdom regulations was clearly beyond reach. Suriname did concede, however, to limit the number of passports issued in Paramaribo. This measure would never come to fruition and the topic would remain on the political agenda. In the early 1960 s Governor Jan van Tilburg reported that also within the Surinamese Staten and cabinet 'there is a feeling of discomfort regarding the problems apparently caused by some Surinamese in the Netherlands, which could place the Surinamese society in the Netherlands unnecessarily in the wrong. ${ }^{9}$ It is worth remembering that around that time the number of Surinamese in the metropolis was estimated at a mere 8,ooo.

During the 1960 ministerial discussions on the subject - although infrequent - continued to aim at ways to restrict immigration from the Kingdom partners, this time focusing specifically on people coming into the Netherlands without previously securing employment. Once again the cabinet voiced concern about the 'unacceptable situation' that anyone from Suriname and the Antilles was free to take up residency in the Netherlands, whereas in reverse this was impossible. ${ }^{10}$ When in 1962 a study group comprising civil servants of several Dutch Ministries - looked into the problem of the 'antisocial Surinamese in the metropolis', it was concluded that the introduction of a restrictive Dutch immigration policy for overseas Kingdom citizens was the only feasible option for changing this 'undesirable situation'. Yet although the study group considered this a legal possibility - remarkably, the right of abode in the Netherlands for Kingdom citizens has no foundation in the Dutch Constitution - this was seen as politically objectionable. Thus The Hague did not sympathise with the 
1962 British Commonwealth Immigrants Act with its distinction between British citizens and (second class) British passport holders; inhabitants of the Caribbean territories were classified in this second group. In the Netherlands this was generally viewed as 'a painful precedent'. ${ }^{11}$ The subsequent de Quay administration (1959-1963) would incidentally voice concern about the growing number of Surinamese within its national borders, in particular about the supposed dangers of criminal behaviour, but did not implement any policy changes.

As of the mid-196os up until the 1980s, the focus of cabinet would gradually shift from a possible curbing of Caribbean immigration to an acceptance of the situation and to a dealing with the flow in a pragmatic manner - both through improving information available to prospective migrants in Suriname and through welfare work for the benefit of Surinamese (and Antilleans) settling or already residing in the Netherlands. A study group for the Ministry of Culture, Recreation and Social Work was the first to conclude in clear terms that 'as long as there remains a considerable difference in development between Suriname and the Netherlands, the migration of Surinamese to the metropolis, also as a result of relationships historically developed, will have to be accepted. ${ }^{12}$

The possibility of long-term reliance on the Dutch social security system by many Surinamese migrants would continue to worry The Hague. The issue of Caribbean immigration became of increasing political importance. In the conservative media and also in parliament, the question as to whether this could be stopped was frequently put forward. Rather at odds with this, a State Commission on the reform of the Dutch Constitution proposed adopting a constitutional guarantee giving the right of abode to citizens from the Dutch Caribbean. Not surprisingly, the successive cabinets led by de Jong (1967-1971), Biesheuvel (1971-1973) and den Uyl (1973-1977) would receive only lukewarm support from parliament for the proposal. Indeed, the new Dutch Constitution, which finally took effect in 1983, makes no mention of this right, thus leaving open the possibility to introduce a restrictive policy at some later stage.

Not only the Curaçao revolt of 30 May 1969 and the following military intervention functioned as a catalyst for Dutch thinking on the decolonisation process, but also the increase of Caribbean immigration, still mainly from Suriname. In July 1971 the Biesheuvel administration included in its coalition agreement the possibility of introducing a restrictive immigration policy for Kingdom citizens from the Caribbean. One month later a Dutch parliamentary delegation visiting Suriname and the Antilles spoke of the likelihood of realising independence 'in the mid-197os. ${ }^{13}$ Unintentionally this would only further encourage migration towards the Netherlands.

Around the same time the Dutch Ministry of Culture, Recreation and Social Work would develop more active welfare policies for immigrants of 
Caribbean origin. Their unverifiable number, however, did not facilitate an adequate implementation. In large cities such as Rotterdam there were occasional reports of 'alarming tensions' between native Dutch on the one hand and Surinamese and Antilleans on the other. The press would make frequent reference to such problems. Dutch attempts to come up with a joint policy with the Kingdom partners reached no further than the establishment of an advisory commission presided by the high-ranking Dutch civil servant B.H. Adam, in April 1972, to improve the preparation of Surinamese and Antilleans migrating to the Netherlands. This was essentially a solitary effort and only marginally successful since Paramaribo and Willemstad were largely uninterested in what they perceived to be a marginal Dutch problem. Meanwhile, on a Dutch ministerial level, the introduction of a restrictive immigration policy for Surinamese and Antilleans was found to be desirable and a plea was made for research into the legal implications. ${ }^{14}$ Shortly afterwards, in June 1972, the Biesheuvel cabinet indeed established a secret and exclusively Dutch 'Commission Fonteyn/Mok' for the preparation of such an immigration policy.

\section{The Independence of Suriname and the Exodus, 1973-1980}

When Labour Prime Minister Joop den Uyl took office in May 1973, he inherited a migration issue that within Dutch society and politics was considered problematic, as well as a series of commissions that were either directly or indirectly concerned with the matter. Within the Kingdom he had to deal with two Caribbean governments that saw immigration as primarily a Dutch issue.

The stated objective of the progressive den Uyl-cabinet, that of realizing independence for both Caribbean territories as soon as possible, would only serve to complicate matters. Merely stating this short-term goal would fuel the Surinamese exodus. At the same time the cabinet was striving for a harmonious atmosphere in its dealings with the former colonies, leaving behind paternalism and neo-colonialism. In this spirit the left-wing parties dominating the cabinet liked to argue in favour of the underprivileged within society - this included not only its traditional white urban constituents, but equally the majority of recent Caribbean immigrants settling in the same urban environment. Similarly, den Uyl's PvdA traditionally maintained close relations with local administrators of Amsterdam and Rotterdam, the two cities where most Surinamese were taking up residence and which regularly called attention to the inherent problems. It is not surprising that the policy under den Uyl would be mainly reactive and in the end only experience limited success within this rather complicated context.

In 1974 the secret Commission Fonteyn/Mok issued its report as well as a 
corresponding draft law for restricting the immigration of Surinamese and Antilleans into the Netherlands. The Commission concluded that a legal restriction would neither conflict with the Charter or with the Dutch constitution, nor with international treaties. In essence the free movement of Surinamese and Antilleans within the Kingdom would be maintained, with the proviso that immigrants must apply for an authorisation if their stay was to exceed six months, whereby applicants should prove that they had gained employment and a place of residence. Although legally admissible, the cabinet of den Uyl decided not to follow this more rigid line and opted instead for the proposals of the tripartite 'Commission Hendriks', focusing on increased support and assistance for Surinamese and Antilleans within the Netherlands without simultaneously curbing immigration. Within cabinet it was generally believed that the independence of Suriname, coupled with a new nationality regulation, would be the preferred path to halt the emigration flow with its 'particularly ominous' aspects. The objective of curbing immigration thus became explicit in the Dutch push for transferring sovereignty to Suriname..$^{15}$

The declaration made by the Surinamese premier Henck Arron on 15 February 1974, in which he announced that sovereignty would be transferred by the end of 1975, was to become a pivotal point in the migration debate. Many would show their lack of confidence in the future Republic by voting with their feet and searching for an arguably more secure future in the mother country. The exodus would be viewed with mixed feelings. Despite intense discussions, particularly in the Netherlands, on how to reverse this trend, there was a general consensus that a direct, unilateral Dutch intervention was neither feasible nor desirable: 'Now the Netherlands needs to accept the consequences of the unique legal framework of the Charter, of which we have always been so proud. Surinamese and Antilleans are Dutch citizens, granted equal rights', so den Uyl affirmed. ${ }^{16}$

In this sensitive context Dutch policy would be tailored in such a way as to avoid confrontation with the Arron cabinet. In doing so it would not endanger its prime objective - the transfer of sovereignty before the end of 1975 - and would prevent any knee jerk reactions regarding a future halt to immigration, which would only exacerbate the ongoing exodus. Solving the migration problem via a restrictive immigration policy was gradually rejected within Dutch cabinet, as this was clearly unacceptable to Suriname, where hopes even stretched to retaining the right of abode in the Netherlands for an undetermined period after independence. Arron, turning this into a matter of prime importance, lacked both the will and the means of prohibiting Surinamese leaving the country. On a visit in Amsterdam Arron made a dramatic appeal to his kondreman (compatriots) to return to Suriname: 'My philosophy is - and I am going to say this straight - you do not belong here. You belong in Suriname, where we will join hands and communally undertake the building of Suriname, $[$... $]$ you are not happy in 
the Netherlands. ${ }^{17} \mathrm{~A}$ burst of applause was all he received and the panic exodus of tens of thousands of Surinamese continued unabated. Remarkably, even Arron and the mentor of Surinamese nationalism Eddy Bruma, both outspoken advocates of independence, would continue pleading for the continuation of free movement between Suriname and the Netherlands and refrain from an active policy of remigration. They understood not only their incapacity to put an end to migration, but equally that the exodus presented a valuable trump card in Surinamese-Dutch negotiations on the 'dowry'.

In August 1974 documents of the Dutch section of the Kingdom Commission preparing Suriname's independence leaked out regarding a new nationality law after the transfer of sovereignty. They focused on the place of birth as the decisive criterion for conferring nationality: 'All Surinamese (connected with that country through prior residence or birth), thus also those staying in the Netherlands, will receive Surinamese nationality following independence. In the Netherlands they will be treated as Dutch citizens, with the exception of the right to vote and military service.' Furious, the Surinamese delegates rejected this proposal: Surinamese were Dutch and therefore the Surinamese nationality could not be 'imposed'. Since they had international law on their side, The Hague had no option but to comply. Henceforward the criterion would be based on the country of residence at the time of independence, which therefore did not necessarily mean the loss of Dutch nationality. In the next round of negotiations, the Dutch even agreed with a phase of transition, until 1980, during which all Surinamese still had the right to opt for settling in the Netherlands and thus becoming full Dutch citizens. The definitive nationality choice thus could be delayed for another five years. Den Uyl did not conceal his despondency about this outcome: 'The regulations proposed could possibly cause more problems than the amount of development aid.' He feared the continuing link between 'the two communicating vessels, Suriname and the Netherlands. ${ }^{18}$

Clearly, this compromise was diametrically opposed to the outcome The Hague had initially envisaged. High officials warned that this regulation, favouring those residing in the Netherlands at the day of independence, would only serve as an encouragement to settle in time in the metropolis. Yet within Dutch parliament den Uyl defended this line of action on grounds of principle, rejecting an immigration policy 'because somewhere that notion of equality floats to the surface and because we believe in the necessity of people, populations and groups tolerating each other. We will follow this just cause regardless of its popularity. ${ }^{19}$ Any hint of discrimination was to be avoided. The fear that skin colour would become the criterion for enforcement played an important role in all of this. But pragmatic grounds were also advanced; 'nothing but disaster' was expected from an immigration policy since it was now too late; effective control 
thereof would be impossible; a stringent immigration policy would only result in an enormous immigration wave in the short-term; and this would probably cause considerable unrest amongst the Surinamese already residing in the Netherlands. The only other suggestion made within cabinet for curbing immigration was to advance the date of independence; although highly unrealistic, den Uyl believed that this option 'should not be thrown overboard'. ${ }^{20}$ With the Dutch officially rejecting a restrictive immigration policy, Paramaribo would cooperate with the registration of emigrants, which had been strongly pleaded for by the Netherlands. In reality very little would come of this.

On 26 June 1975, five months before the transfer of sovereignty, Suriname and the Netherlands reached full agreement on a migration policy to be adopted following independence. Surinamese residing in the Netherlands on Independence Day, 25 November 1975, would receive Dutch citizenship. Surinamese nationality would be obtained by those born in Suriname as well as living there, or having their main residence there at the date of independence. With Surinamese nationality being obtained, Dutch nationality would be lost. Furthermore, Surinamese wanting to take up residency in the Netherlands after independence would be exempt from visa requirements until November 1980 on the condition that they could prove to have acquired accommodation and means for subsistence. This was a compromise: Suriname had not wanted any visa requirements at all, whereas initially the Netherlands had. In this way the virtually free migation to the Netherlands would continue unimpeded during the first five years following independence.

For Suriname the results of this episode have been dramatic. Between July and November 1975 the emigration flow continued: each month 3 to 4,ooo Surinamese, unconfident about the economic and political future of their country, left for the Netherlands. Dutch policies failed to allay serious doubts of many concerning the future of the Republic. The Dutch cabinet had to admit that once again the flow was larger than expected. Suggested solutions even included reducing the amount of available airline seats on the route Paramaribo-Amsterdam - where the Royal Dutch Airlines KLM was making good money by considerably increasing its number of flights buying these and thus blocking them. In the end, however, The Hague simply allowed things to take their natural course.

Between 25 November 1975 and the same date in 1980 another 30,000 Surinamese would settle in the Netherlands and obtain Dutch nationality. As pointed out above, due to the exodus the total population of the Republic has barely grown, while the size of the Surinamese society within the Netherlands, including second and third generations, is now estimated at over 315,00o. For the just over 400,ooo citizens of the Republic of Suriname this development has had far-reaching and, according to some, catastrophic effects. 
What of Dutch society? During the 1950 and the early 1960 s the immigration wave from Suriname had been of a very modest nature, yet was viewed unfavourably within Dutch politics and the civil service. During the 1960 s and 1970 s the size of the migration flow increased considerably, culminating in an exodus. It was almost unavoidable that this development would give rise to negative reactions within Dutch society, but this has never resulted in an organised xenophobia or a specifically anti-Surinamese movement, nor have there been frequent spontaneous protests. Nevertheless, Dutch politics and the civil service over the years regularly referred to the assumed diluting social support for the reception of 'yet more Surinamese', partly as a result of which they spoke out in favour of curbing immigration.

Several divergent views on immigration battled for supremacy within Dutch politics in these years (and actually today anew with regard to Antillean migration). Almost unanimously the arrival of large numbers of Surinamese was seen as problematic for Dutch society. At the same time there was a general feeling that it would be impossible to close the borders, due to all Surinamese and Antilleans enjoying full metropolitan citizenship and to the fear that such a measure could be interpreted as a sign of xenophobia - a sign not at all fitting the rosy Dutch self-image that the administrative and intellectual elites so cherished.

With the increased flow of immigrants, attention shifted to the implications for Suriname itself, which had to deal with a debilitating drain. On the eve of independence this point of view increasingly gained power. Dutch politics stood before the virtually impossible task of reconciling the interests of the future Republic, damaged by the exodus, and those of individual Surinamese who made use of their rights as Kingdom citizens by exchanging their native country for the wealthier and more secure metropolis. A further complication was that successive Surinamese cabinets found it unacceptable to deny their citizens free access to the Netherlands. For The Hague, reaching the transfer of sovereignty in harmony was of primary concern; as a result the Surinamese exodus would automatically come to an end, or so it was assumed.

Within this complex situation Dutch policy would remain ambivalent to the end. A long series of commissions investigated the possibility of introducing an immigration law for Caribbean 'compatriots'. In most cases the conclusion was that, although legally feasible, this would be politically too sensitive and thus undesired. Instead, solutions were sought in the stimulation of Suriname's economic development, and in doing so reducing the desire to emigrate. Confronted with the failure of this strategy, preference was given to a rigourous coupling of a rapid independence with the ending of free access to the Netherlands, in the hope that in this way Surinamese immigration could be brought to an end, sooner rather than later. At the same time a Dutch safety net was stretched out to speed up Surinamese integration and to avoid confrontation with the native Dutch 
population. It is ironic that measures taken in the spheres of housing and social support would make ministers from the Arron cabinet complain but only behind closed doors - that the Netherlands was making it too attractive for their citizens to embark upon the one-way journey.

Dutch policy may have failed completely in its attempt to stem Surinamese immigration, but integration has been achieved with relative success, at least in the sense that there has been no major civil unrest and that Surinamese have done relatively well in Dutch society. Along with the possibility to make a new start, for the individual Surinamer who made the crossing to the Netherlands and struggled for a place in society this has been a positive outcome. The losing party in this migration history became the young Republic of Suriname, beginning its history in 1975 with a severe loss in human capital that would only continue in the following years. In retrospect a harsher Dutch position would have been more beneficial for the Republic. In this context it is telling that the Dutch Labour Minister for Development Aid, Jan Pronk, at the time representing the radical left of his party, once let slip that a right-wing cabinet would probably have handled the decolonisation of Suriname better. Early in 1974 precisely the rightwing parties (both the conservative liberal VvD and Ds' 70 ) had pleaded for a restrictive immigration policy for the Dutch Caribbean to take effect immediately.

In retrospect Pronk was typically casual in his evaluation. 'I found that the immigration was given too much weight as an issue in the Netherlands. The numbers were exaggerated. The Surinamese have integrated well into Dutch society. The Netherlands has not been harmed. Yes, Suriname has indeed been harmed. Yet I believe that mass emigration was the price to be paid during a certain period in order to offer security to the Hindustani. I have always believed in a long transitional phase, a double passport, not in abrupt measures. If things had turned out well in Suriname, many would probably have returned. It was more the crisis of 1980 [following the military coup led by Desi Bouterse] that has made this migration irreversible. ${ }^{21}$

On the Surinamese side views are mixed. The late Jnan Adhin, then prominent member of the Hindustani vHP, stated in hindsight: 'I found the Treaty of 1975, which gave Surinamese the liberty to choose during another five years, not a good regulation. In fact they should have introduced a visa requirement for the Netherlands right from the start of independence.' Looking back, the leader of the vHP, the late Jagernath Lachmon, was still in doubt: 'At the time I never said to the Netherlands that an immigration policy should be introduced. I do not know whether in hindsight this would in fact have been a good idea.' Chairman of the Surinamese Staten Emile Wijntuin still supports the decision making: 'I think that if an immigration policy had been introduced, the feelings of unrest in Suriname would have been far greater, with all the inherent consequences. The best solution was to let the people go.'22 
The migration issue had thus become of paramount importance within Kingdom relations. After the independence of Suriname, history would repeat itself with the Netherlands Antilles and Aruba, albeit with different accents and within a different political and social context.

In 1975 the number of Antilleans residing in the Netherlands was low, at only 24,000 . In 2000 this number had increased to almost 120,000, the largest proportion coming from Curaçao, which has had to deal with longrunning economic stagnation combined with a social crisis pervading all sectors of society. An estimated one third of the Antillean population in the Netherlands is second generation, born in the metropolis. ${ }^{23}$

The size of the Antillean community in the Netherlands is still modest in relation to the Surinamese, Turkish or Moroccon populations. More dramatically, the number of immigrants from Curaçao is almost on a par with the number still residing on the island. With 130,627 inhabitants, in 2001 the island's population has decreased by over ten per cent since 1992 $(144,097)$ - similarly, between 1992 and 2001 the entire Antillean population has decreased by almost seven per cent, amounting to a total of 175,653 inhabitants in $2001 .^{24}$ Clearly, a new exodus has taken place. Aruba on the other hand has seen prosperous development on the island, resulting in a population increase from 60,00o to over 90,00o in the period between 1985 and $2000 .{ }^{25}$

Although the Dutch never closed their borders to their Caribbean 'compatriots', they did not bar the possibility to do so. During the first years following the transfer of sovereignty to Suriname, Dutch political thinking on legal measures for curbing immigration seemed to have lost its relevance. Questions from members of parliament concerning Antillean immigrants were brushed aside, the small numbers being 'no cause for serious concern', particularly in view of the fact that they were mainly students and recruited workers. In the same vein, a 1977 memorandum by the Ministry for Culture, Recreation and Social Work on Caribbean immigrants in the metropolis primarily focused on the Surinamese. The fact that there was a slightly growing number of Antillean immigrants facing adjustment problems was not yet an issue of political importance.

Gradually this would change, particularly with the draw of an increasingly prosperous metropolis for lower-class Antillean youth. When in 1980 the emigration level on the islands exceeded 3,00o, the Dutch conservative liberal party VvD set alarm bells ringing, urging the cabinet to discuss the restriction of Antillean immigration. Even if the memory of the previous Surinamese exodus gave extra gravity to the situation, no action was taken and Willemstad was reassured to this effect. Behind closed doors however, pleas for a stricter policy would receive growing support, only to be fuelled further in the mid-1980s as it became apparent that the Antilles refused to 
accept 'the gift' of sovereignty and could not be forced to do so - it was only likely that at some point many Antilleans and Arubans would exercise their right of free abode in the metropolis.

In this context some concern appeared justified. A Dutch study carried out in 1985 revealed that even if Antilleans often had a relatively advantageous starting point, their job opportunities were rather low, lower in fact than some other immigrant communities in the Netherlands and certainly lower than the Surinamese. One of the major causes, so the report stated, lay in the poor command of the Dutch language among many of the Papiamentu-speaking Antilleans, combined with an often insufficient preparation for their new lives in the Netherlands. ${ }^{26}$ As will be discussed in the next chapter, in contrast to Suriname Dutch has remained a rather marginal language on the islands, where either Papiamentu dominates (Leeward Islands) or a creole form of English is spoken (Windward Islands). Clearly this is the harvest of a long history of careless colonialism, with the Dutch failing to develop the islands after their own model. The ensuing problems became more prevalent in the 1990s, with the population of Antilleans in the metropolis continuing to grow.

During the 199os Antillean emigration to the Netherlands saw a dramatic increase, reaching an annual level of above 6,000 in the second half of the decade. There was open talk of an exodus. This time among the emigrants there were many unaccompanied adolescents, speaking only Papiamentu, often school drop-outs who, once in the metropolis, tended to find themselves isolated from mainstream society, with for a considerable minority the often predictable outcome of living a life 'in the fast lane' of drugs and criminality.

Before long, opinion both from the public and politicians began to turn against this Antillean presence. In particular within the 'Antilles municipalities' - large cities where many Antilleans reside - there was a growing desire to curb migration and control Antillean migrants, particularly as there were increasingly regular occurrences of serious crime by groups of Antillean teenage drop-outs. In the explanatory memorandum of the 1993 national budget, the Dutch government expressed its concern in plain words: 'Dutch after-care and resettlement organisations for the youth have recently been faced with serious and often aggressive criminality by certain groups of Antillean youth.' In this perspective the significance of the Dutch language on the islands received a new dimension: 'Within the context of durable Kingdom relationships education is no longer only of Antillean concern, but also that of the Kingdom. The Netherlands cannot remain passive with large numbers of young Antilleans repeatedly getting into trouble in the Netherlands. ${ }^{27}$

The Dutch government wanted action, on both sides of the Atlantic. Indeed, since the beginning of the 1990s there has been much transatlantic consultation concerning the problems of lower-class, poorly educated An- 
tillean migrants. As the awareness of joint bilateral benefits grew, in early 1992 the bilateral 'Task Force Antillean Youth' was founded with the goal of finding structural solutions through improving living conditions and prospects on the islands. The Antillean education system became a primary concern. The Task Force spoke of an alarming situation: high percentages of school drop-outs on Curaçao were associated with drug abuse, teenage pregnancies, criminality, youth prostitution and AIDS, and had 'apparently taken forms which we no longer have control over and against which we appear to stand powerless. ${ }^{28}$ In order to combat problems, the Task Force pleaded for fundamental changes across the board, for which irrevocably the aid of the Netherlands and the private sector is needed'. It was reiterated that the primary cause lay on the islands themselves, the core of the problems being the overall malaise, in particular on Curaçao; in fact the problems were already taking place on the islands before emigration, and thus initially needed to be dealt with over there.

During the course of the 1990s migration would became a true political battle ground between Willemstad and The Hague. Within a relatively short time the exodus had caused serious social problems in the metropolis. Dissatisfaction was growing in the large cities, where integration was to a large extent clearly failing. Meanwhile there was Dutch distrust of Willemstad's willingness to cooperate in reversing the situation, which was only fuelled by comments made by Amsterdam's chief of police, Eric Nordholt. Early in 1993 he stated that the Antillean authorities were actively involved in sending young criminals to the Netherlands. A police investigation into the matter did not yield concrete evidence; nevertheless suspicions remained.

In June 1996 the Task Force concluded that the situation of many young Dutch Antilleans had only deteriorated further, with a growing number lacking prospects both on the islands and in the Netherlands, mainly due to the lack of skill related training. This is clearly visible in the disproportionate levels of unemployment - with youth unemployment in 2001 standing at $34 \%$ and Antillean unemployment as a whole at $16 \%{ }^{29}$ Meanwhile the youth assistance programme proved incapable of providing the necessary structure. In the crucial fields of education and the labour market little or nothing had improved throughout the 199os. In the House of Commons disappointment was voiced on all sides and it was generally felt that Joris Voorhoeve, the then minister concerned, was dragging his heels on the issue.

Inevitably in this context, the feasibility of introducing a restrictive immigration law for Kingdom citizens resurfaced on the political agenda. In retrospect Voorhoeve states that he had actually been advocating this right from the start: 'I have always believed in the possibility of a sensible, not unduly discriminatory migration regulation within the Kingdom. ${ }^{30}$ However, when in 1996, at his instigation, the Ministry of Justice issued a mem- 
orandum on the subject, this appeared beyond discussion - even within cabinet Voorhoeve failed to get the undivided support of his fellow conservative liberal (VvD) ministers. During his term in office he would not take any further initiatives in this field.

By the end of the 1990s one third of the Antillean population had fled the deep crisis on the islands and settled in the metropolis, increasing the original number of Antilleans fivefold in three decades - to give some balance, this includes a worrisome brain drain detrimental to the Netherlands Antilles. At the end of the twentieth century for the first time in history The Hague has seriously inventorised possible legal steps to regulate immigration from the Dutch Caribbean. The 1998 joint policy memorandum Nota Migratie Antilliaanse Jongeren ('Young Antillean Migrants') issued by the Minister for Urban Policy and Integration of Ethnic Minorities Roger van Boxtel and State Secretary Gijs de Vries, elaborated and indicated possible legal measures for curbing Antillean migration to the metropolis (this by definition includes Aruba, although migration from this flourishing island to the Netherlands is neither extensive nor problematic). A painful milestone, although as yet this initiative has lead to very little in real terms.

It is indeed contested whether in actual fact the options put forward would be legally feasible. As stated in the beginning of this chapter, not only would a lawful limitation of Caribbean immigration require close cooperation between the three governments (Antilleans and Arubans having Dutch nationality) but in addition, a truly restrictive policy no longer seems attainable within the new context of European unification. The Dutch passport carried by the Dutch, Antilleans and Arubans alike is now valid in all member states of the European Union. Moreover, the Antilles and Aruba themselves are associated (since 1964) with the Union under the 'Overseas Countries and Territories Decision'. Even though technically speaking the islands do not form part of the territory of the Union, the provisions for freedom of movement within the member states are extended to the associated territories and thus apply to all Antillians and Arubans. ${ }^{31}$

Instead of embarking upon a legal route, the second purple cabinet under Wim Kok intensified policies aimed at limiting the number of incoming unaccompanied minors from the Antilles through a number of bilateral agreements (1999, 2000) regarding inburgeringscursussen - introductory courses on elementary Dutch and Dutch culture for this category of immigrants - both on the islands and in the Netherlands. Cabinet plans to make these courses obligatory, with prospective migrants needing to take an exam before actually being allowed to leave, have not materialised due to Antillean opposition. Instead The Hague opted for including Antillean immigrants in the general Dutch minority policy of providing obligatory training in the Netherlands itself. Meanwhile the Dutch government has been allocating increasing sums to the 'Antilles municipalities' for helping to alleviate housing, educational and welfare problems. Ironically, the per 
capita amounts involved in this are in many cases higher than Dutch aid extended to the islands for such problems.

Alarmed by these factors and well aware of the risks of further negative publicity, prominent Antilleans living in the Netherlands would increasingly contribute to debates on Antillean criminality and its solutions with both the Dutch and the Antillean community. ${ }^{32}$ In the view of the Plenipotentiary Minister Carel de Haseth, the increasingly vehement public debates in the later 1990s on migration issues served to sour Dutch-Antillean relations more than anything else. From the Antillean point of view, the level of education among the fellow immigrants was systematically underestimated, the levels of deviant behaviour and in particular criminality unduly overemphasised. Not only was there general resentment among Antilleans to be equated with troublesome immigrants rather than as fellow citizens of the Kingdom, but Antillean politicians also felt unduly accused of refusing to stem a tide they themselves could not control. ${ }^{33}$

To conclude, Dutch attitudes thus became entrenched and in some quarters even hostile, both as a reaction to the exodus and to the perception that so far the Antilles have not been really cooperative in dealing with this problem. At the beginning of the twenty-first century Dutch policy targets have become increasingly harsh, yet instruments remain few. The most recent figures indicate a considerable slowdown in the migration surplus from the Antilles in the past few years. ${ }^{34}$ It remains to be seen whether this is more than a temporary lull, allowing for this issue to lose its priority place on the Kingdom agenda. It seems unwise to think that migration to the more prosperous, and in most dimensions, more challenging metropolis will ever come to a halt, more so now that a genuine transnational Antillean community has developed. A comparative perspective too suggests that it is unlikely that this migration will stop, or that a return migration of major significance will develop, no matter what Dutch politicians say or legislate. Either way, it will be a particular challenge for Dutch society at large to help the increasingly Dutch-born Antillean community to develop the necessary educational background and skills for successful integration.

Meanwhile, in 2001, the Antilles - but not Aruba - have gone some way to comply with the long-standing Dutch demand to extend the reciprocal right of unrestricted access to Dutch citizens. In legal terms it seems this is all there is to it. Within the present context of durable Kingdom relations, solutions for migration issues are a shared concern and will need to be found within the Charter. In this context it should be emphasised that for the Antilles and Aruba there is really a great deal at stake. Not only is free access to the Netherlands a long-standing right, but it is also cited by their own populations as the primary motive for wanting the constitutional link with the metropolis to continue. ${ }^{35}$ 


\section{A Comparative Perspective}

All the former colonisers included in this study have a long-standing history of immigration from the Caribbean, dating back to the time of slavery. However, only in the period from the end of World War II up until the present has migration reached dramatic levels. By 1990, some twelve per cent of all citizens born in the non-sovereign Caribbean were living in the Unites States and Canada; this figure, which does not include the considerable West Indian migration to the United Kingdom, would only increase during the 1990s. In 1990, proportionally there were almost 75 Puerto Ricans living in the United States for every 100 on the island itself, and 55 Surinamese in the Netherlands for every 100 in Suriname; for Jamaica, Martinique and Guadeloupe, for every 100 in the home population some 45 were living abroad. These percentages have only continued to increase in the subsequent decade. ${ }^{36}$ In the post-war period, one quarter of the inhabitants of the English-speaking Caribbean, one third of the residents of the départements d'outre-mer and almost half of the Puertoricans live 'abroad'. These levels show a clear exodus. The impact is considerable, on both sides of the Atlantic. For all former colonisers and colonies the persistent emigration from the Caribbean now represents one of the most challenging issues to be tackled.

The British have dealt with the influx from the Caribbean in a different manner from the other metropoles. Concerned by the high levels of immigration from many of their former colonies in Asia, Africa and the Caribbean during the 1950 , and particularly by the prospect of a dramatic increase in these levels, they introduced restrictive border controls early in the 196os, which remained in place until recently. ${ }^{37}$ Thus the Anglophone Caribbean exodus found a different focus, namely the United States and Canada, where at present the number of 'British' West Indians stands at approximately one and a half million. In the United Kingdom residents of Caribbean origin number 600,000, with most having arrived between 1955 and 1962. The expansion of the community during the following decades has been largely due to demographic growth.

By reserving British nationality for inhabitants of the United Kingdom, the Commonwealth Immigrants Act of 1962 created a distinction between British citizens and 'second class' (mainly non-white) British passport holders with limited access to the United Kingdom. Westminster showed little concern for possible accusations of discrimination. Pragmatically, it argued that the necessity for this action was a response to the increasing number of immigrants from the dependent territories taking up permanent residency in the metropolis. The Immigration Acts of 1968, 1971 and 1977 saw a further tightening of restrictions, imposing controls on entry to the United Kingdom either for settlement or for visits. The 1981 British Nationality Act under the Conservative government of Margaret Thatcher saw the final 
stripping away of citizenship rights in the dependent territories by creating a specific category for those belonging to these territories. These subsequently became 'British dependent territory passport holders', which was rather a form of paper identity turning them into 'citizens of nowhere', since under this provision individuals in the territories were deprived of any clear form of citizenship rights..$^{38}$ The further sharpening of immigration laws during the 198 os can be directly linked to the imminent handover, in 1997, of the Crown Colony of Hong Kong to China. The British government feared that a significant number of the six million inhabitants of Hong Kong would prefer to emigrate to the United Kingdom rather than live under the rule of Bejing.

All along, the people of the dependent territories, some of which have only ever known British sovereignty, harboured a strong sense of injustice at not enjoying British citizenship. Not only have individuals had practical difficulties when wanting to travel to the United Kingdom, the United States or the European Union, but in higher education their status has been that of overseas students, required to pay the respective overseas fees while European Union students pay standard fees. However, with the loss of Hong Kong reducing the total number of inhabitants in the overseas territories to hundreds of thousands rather than millions, along with the landslide Labour victory of May 1997, London relaxed its hard line and, as part of the overall review of relations with the remaining territories, has offered full British citizenship to their populations. Thus, following the March 1999 White Paper Partnership for Progress and Prosperity, inhabitants of the newly renamed 'Overseas Territories' - six of these located in the Caribbean - saw their status greatly elevated, now with the right of abode in the United Kingdom. In accordance with the wishes of the territories, no reciprocity was required in exchange, with a view to avoiding damage to the social and cultural cohesion of the islands.

This restoration of British citizenship, which took effect in May 2002, has greatly pleased British Caribbean governments, who had long pushed for this right. This 'noble gesture' was thus generally felt to be long overdue. It is telling that it took the Labour government three years to convert the offer into legislation. British citizenship has not been granted without a price: in exchange the overseas territories are obliged to demonstrate their commitment to the rule of law and good government and observe international standards in human rights and financial regulation. Local governments are also required to deal head on with drug trafficking and money laundering, problems high on the world political agenda due to their links to the funding of terrorism. In the metropolis there has been some concern voiced at a possible extensive use of the newly acquired right to take up permanent residency in the United Kingdom. Yet this seems an unlikely prospect, considering seventy per cent of the total population of these territories has higher per capita incomes than the British average. 
The 2002 British Overseas Territories Act is thus more likely to facilitate a modest form of circular migration. ${ }^{39}$

Under the European Union provisions for the granting of British citizenship to the overseas territories, community rights of free movement within member states of the European Union were also conferred. These rights already existed in the French territories: the départements d'outre-mer (DOM) form part of the European Union and their residents traditionally enjoy full metropolitan citizenship. The post-war policy of decolonisation through assimilation and integration into the French system granted French status to Guadeloupe, Martinique and Guyane, as integral parts of the métropole. This status of equality has greatly reduced the cultural gap, as well as the perceived geographical distance between continental France and the DoM. Accordingly, migration from the Dom has always been drawn almost exclusively to the metropolis. Today approximately 215,00o French citizens born in the ром (mainly from the islands of Martinique and Guadeloupe) reside in the Republic; the total French Caribbean population in France, concentrated in and around Paris, is well above that figure. The number of inhabitants of the Caribbean Dom amounts to $1,000,000 .{ }^{40}$ The right of abode is reciprocal; in fact France provides important technical assistance to local governments, with large numbers of civil servants around 30,000 in the DOM - helping to balance numerical discrepancies in emigration. The local Dom populations show a permanent emigration surplus. Black intellectuals such as the former Martiniquan grand man Aimé Césaire have spoken vehemently but in vain against the effects of this constant crossing of the Atlantic, fearing this will lead to a form of 'genocide by substitution'.41 This phenomenon is further gaining momentum by the steady influx of metropolitan French.

Decades of economically driven migration, further stimulated by French policies attempting to reduce cyclical labour shortages at home and to reduce structural high unemployment in the overseas departments, have seen the French Caribbean population in the metropolis increase to their present high levels. ${ }^{42}$ After the worldwide crisis of the 1970s, French policies aimed at redressing the flow through subsidised repatriation proved largely unsuccessful. Instead, when it became clear during the course of the 1970s that the settlement of French West Indians on the continent was semi-permanent at least, policies were aimed at improving their employment prospects and at promoting social and cultural integration - political integration already existed under the laws of assimilation, possibly one reason for their rather peaceful integration.

This Caribbean community in the metropolis, also referred to as 'the third island'43, is of major importance to the Dom. Almost all Dom residents have relatives living in France, who they regularly visit and from whom they may receive financial support. By allowing their residents the free choice to emigrate to the métropole, local governments manage to 'ex- 
port' their unemployment, which serves to increase the standard of living of the remaining population. The French government has always presented migration in this manner - albeit to a greater or lesser degree, depending on the party in office - namely as a valuable option for the Doм. Of course there is also a degree of self-interest at play here, due to the large value that France traditionally attaches to maintaining strong ties with its territories and thus upholding a worldwide presence in tune with its status of a world player with grandeur - even if much of that belongs to the past.

At the same time this privileged incorporation makes it very difficult for the Dом to find a true Caribbean identity: to their residents France remains l'état, which, in combination with the language barrier, insulates them - culturally and economically - from their neighbouring territories. These are less favourable conditions for developing a strong national identity and sense of nationhood. Critics of post-war French migration policies accuse the government of 'neo-colonial exploitation' of Dom residents, since its prime motivation for having stimulated this migration was levelled at the Dom's overpopulation, which, if ever sincere, at present seems to have become largely irrelevant. On the contrary, the persistent drain of young people damages the vitality of these territories. Furthermore, emigration is taking place alongside the immigration of métropolitains who often take up professional positions in the Dом and thus reduce job opportunities for locals, which inevitably leads to frustration. The high level of migration to the métropole can be seen as proof of the lack of real development in the overseas economies. Despite extensive emigration and relatively high standards of living, unemployment figures in the Dom remain three times higher than those in Europe. ${ }^{44}$

Meanwhile, in the metropolis, the downside to extensive immigration has become clear, with growing economic problems and racial discrimination. Political debates now focus on issues such as urban decay, integration and race relations. Politicians, not only those from extreme-right leanings, make increasingly harsh statements concerning immigration. However, most of this is directed against the extensive Islamic community, not really against the culturally more assimilated residents of the Doм. There is no mention of a possible curbing of Caribbean immigration to France. If there is any disquiet concerning the Dом status, then this is coming from the side of the Dom rather than from the métropole: as long as both strategy and prestige play a role, the link between the French state and the Dom will remain undisputed - despite ever-increasing costs and continued exposure to the Caribbean exodus. These factors are far outweighed by the advantages that France attaches to making its influence felt in the region.

Similar geopolitical considerations play a role in U.s. migration policies for its two associated Caribbean states, Puerto Rico and the U.s. Virgin Islands, whose inhabitants became American nationals in 1917 and 1927 respectively, which conferred the right of abode in the United States. In view 
of the intensive use of this privilege ever since, particularly by Puerto Ricans, whose number in the United States presently stands at over three million against 3.8 million on the island, this arrangement is considered of great importance in the eyes of the population. ${ }^{45}$ Emigration from the U.s. Virgin islands has been proportionally less than that from Puerto Rico, but is still considerable; at the same time the Virgin Islands have had to deal with a large immigration flow from neighbouring islands.

European metropoles have traditionally received very few Caribbean migrants other than from their own territories, but this is not the case for the United States, where for decades large numbers of immigrants from the entire region have flocked. At present a total of more than seven million Caribbean migrants have taken up permanent residency in the United States. The 'Hispanic' diaspora has by far the largest presence. The majority of this community consists of Puerto Ricans (over three million), followed by Cubans (over one million) and Dominicans (over half a million). Approximately one and a half million Caribbean immigrants emanate from the English-speaking territories, the majority from Jamaica. The number of Haitians in the United States is slowly nearing the one million mark.

Like the intensive migration patterns between the DOM and France, migration between the United States and Puerto Rico is considered 'internal' and has developed in an essentially circular manner, even to a greater extent than experienced in the French system. Motives for leaving the island have been mainly financial: Puerto Rico is poorer than any of the federal states. Migration to the continent has thus acted as a permanent release valve for the densely populated island. Despite the fact that many of those leaving Puerto Rico have been able to take advantage of better social and economic opportunities on the continent, for many the concept of 'home' remains firmly focused on the island.

Post-war Puerto Rican emigration has been partly the result of organised transfers by the Puerto Rican Ministry of Employment: as part of a series of measures by the U.s. federal government to try and reduce the population density on the island, a Migrations Division was established in 1947 which acted as a mediator between American companies and Puerto Rican workers. ${ }^{46}$ This project was to give a considerable impetus to the exodus. The world economic recession of the 1970 and 1980 s would only stimulate this exodus, which by then comprised all social classes. Massive migration has seen many, mainly unemployed Puerto Ricans with a poor command of English arriving in the United States. This has inevitably led to problems. Due to the language barrier these groups tend to become marginalised within American society. Following four centuries of Spanish rule the island has remained Spanish-speaking; American policies to americanise 'Porto Rico' have failed, with at present only around ten per cent of the population having fluency in English. Bearing this in mind, it seems unlikely that this situation will change - here parallels to the Papiamentu-speaking 
Dutch Antilleans in the Netherlands, and the ensuing integration problems, are clearly seen.

Many Puerto Ricans now residing in the United States have experienced some deterioration in their social standing. This is partly due to the perceived 'burden' this former colonial possession has become. Invariably, in Congress concern has been voiced regarding the - according to some - unacceptable strains placed on the federal government. Yet there has never been a serious debate on restricting the movement of Puerto Ricans to and from the continent, not even during those periods when immigration from other parts of the world, including from the rest of the Caribbean, was halted. Despite North America's growing unease with the high birth and emigration rates on the island, it would not dream of breaking ties with its 'show window looking south'. Again, as with the French, it is the strategic value of the island which outweighs negative factors. At present the only question remains whether Washington would be prepared to eventually incorporate Puerto Rico into the federal state, despite the increased financial burden as well as the cultural disparity between the island and the continent.

Clearly, the United States, France and the Netherlands have all founded their migration policies towards their Caribbean territories on the same premise, that of allowing free movement. It should be noted however that of these metropoles, the Netherlands is the only country where recently there have been regular calls for the restriction of immigrants from the Caribbean. These calls have increased in reaction to problems associated with free immigration of large groups of essentially non-Dutch-speaking young, underprivileged Antilleans. This is an ironic contrast with the United Kingdom - traditionally restrictive of Caribbean immigration - restoring full citizenship to residents of its remaining overseas territories, albeit only after the hand-over of Hong Kong.

To conclude, structural unemployment and poverty at home and the search for socio-economic opportunities have ensured, and will continue to ensure, migration from the Caribbean, including from the non-sovereign parts of the region, to the wealthy Western European countries and the United States. This has had and still has its rewards for all parties concerned, yet more has been said - particularly in metropolitan circles - regarding the costs. The early influx into the metropoles of Caribbean professional classes became easily assimilated into society. Subsequent massive immigration of the lower strata of Caribbean societies has indeed, and inevitably, contributed to social problems associated with underprivileged ethnic minorities.

Among the four metropolitan powers still present in the Caribbean, the option of simply closing the borders to citizens of their non-sovereign territories has occasionally been implemented (by the United Kingdom) or seriously discussed (by the Netherlands), yet the norm has remained to allow 
for free access. This fully complies with the ardent wishes of all citizens of these non-sovereign Caribbean territories. It is most likely that free right of abode will remain the norm - perhaps a sobering thought for some of the 'mother countries' only recently coming to terms with their inextricable links to a small number of islands. 


\section{Cultural Exchange, Proximity and Distance}

Textbook introductions and, to a larger extent, tourist brochures tend to divide the Caribbean linguistically; the Spanish, British, French and Dutch Caribbean being the four linguistic divisions. ${ }^{1}$ Of course, the linguistic criterion, with its neo-colonial overtones, is just as helpful in categorising the Caribbean as it is misleading in respect of politics or history. After all, inherent in this is the vague suggestion of continuing subordination, while in fact most of the former colonies have long since seceded from the erstwhile metropolis. One may also argue that choosing the metropolitan language as the defining characteristic understates the vital importance of local cultures and indeed languages as such. In the same vein it would make little sense to categorise Haiti, sovereign for two centuries and with a French based Creole rather than French as the vernacular, as part of the French Caribbean.

Such reasoning also applies to the 'Dutch Caribbean', the smallest collectivity in this region to start with. Here the argument should be taken one step further, as we must conclude that in none of these territories Dutch is the mother tongue for the majority of the population. Although in Suriname Dutch has become more prevalent over the past quarter of a century since gaining sovereignty ${ }^{2}-$ it is the official national language and used as such in education and government, albeit often in a Surinamese variation today it is still competing with a variety of ethnic-specific languages. There is the Hindustani Sarnami, the Afro-Surinamese Sranan Tongo (once thought of as an alternative to Dutch and still the only 'ethnic' tongue spoken by many speakers from all groups), various Maroon languages, Javanese Surinamese and several Amerindian languages. On Aruba and the two Leeward Antillean islands, Curaçao and Bonaire, Papiamentu is the undisputed vernacular, with Dutch being used mainly in education and government. The same goes for the Windward Antilles (St. Eustatius, Saba and the Dutch half of St. Martin), with English being the vernacular there. The Antilles have officially designated three national languages: Papiamentu, English and Dutch. In the streets of Willemstad, Oranjestad or Philipsburgh one actually rarely hears locals speaking Dutch.

These tendencies are not a result of decolonisation over the last fifty years - on the contrary, it is in these most recent decades that the use of Dutch has generally increased. The multilingual and predominantly nonDutch character of these societies is a legacy of the preceding centuries of colonialism, in which non-Dutch speakers both in the upper and lower 
strata developed local Creole languages. Thus the Sranan Tongo of Suriname used to be called neger-Engelsch, 'Negro-English', as this language of the African slaves had emerged during the initial British colonisation years, with English providing most of the vocabulary to an African based syntax. Similarly the Papiamentu of Curaçao developed as an African based syntax grounded in the languages of the enslaved Africans with a predominantly Portuguese vocabulary derived from the mother tongue of the Sephardic Jews on the island. Throughout the colonial period, Dutch remained a minority language only spoken by expatriates and some local elites in the Antilles. In Suriname the Dutch language gained foothold as of the late nineteenth century, with the colonial authorities embarking on a policy aimed at introducing an education system based on Dutch as a means to subdue the extant ethnic divisions aggravated by the introduction of Asian indentured labourers. By the early twentieth century the Creole elite of Suriname took pride in the epitaph that theirs was 'the most Dutch of all of the colonies'. Indeed, in comparison to the Antilles and the Dutch East Indies, there was some truth to this claim. ${ }^{3}$

Still, at the time of the promulgation of the Charter, Dutch remained only a second language, even in Suriname. Neither was there any solid ground to affirm that in reality the 'Dutch' Caribbean and the metropolis had much common cultural ground, apart perhaps from the Caribbean elites with their Dutch education and their awareness of political expediency. The question then becomes if The Hague did attempt in any way to narrow cultural distance within the Kingdom during the next half century. How was this approached and what tangible results have become visible? We propose two preliminary answers. Yes, The Hague did make some attempts to this end, although these were neither consistent nor very determined. And yes, there was indeed a tangible narrowing of cultural distance. Yet, so we propose, this had less to do with cultural and education policies on either side of the Atlantic than with the logics of globalisation and migration.

\section{Dutch Passport, Dutch Language?}

By the early twenty-first century the Surinamese community is ranked as one of the more successful ethnic minorities in the Netherlands, while an appreciable number of the Antillean - particularly Curaçaoan - immigrants are more often associated with an array of deviant behaviour. The Surinamese, so the logical argument runs, have a good command of Dutch, irrespective of which side of the Atlantic they were born on. In contrast, a low standard of education and a poor command of the Dutch language are characteristic of many of the Antilleans who settled in the metropolis during the last decade, and from these deficiencies arise predictable problems. 
This being as it is, one may wonder why the Dutch did not embark on an all-out effort to 'Dutchify' the Antilles and in particular their education system years ago.

The answer lies mainly with The Hague's failure to anticipate the rise of the 'minorities issue' which figures ever more prominently on the Dutch political agenda and in the media. Generally, there was no expectation of the predictable problems associated with the settlement of relatively large contingents of migrants from other cultures and language areas (predictable, not only with the advantage of hindsight). Focusing specifically on Caribbean migrants, there was virtually no awareness of the drawbacks facing migrants with a Dutch passport but with little of the educational and linguistic skills of their metropolitan 'compatriots'. On top of this, the 1954 Charter defined education, including the choice of national language, as the responsibility of each individual Kingdom country. Thus, even if Dutch politicians may have nurtured misgivings regarding overseas educational policies, the Charter would allow no direct intervention.

The situation as it presently stands is easily defined. On the Leeward Islands Dutch is the dominant language in the education system, the jurisdiction and public administration, but in daily life it is of very little importance. The disparity between the mother tongue and the Dutch-centred education contributes dramatically to low levels of achievement, with all the inherent negative social, economic and psychological consequences. Since the nineteenth century there has been a fervent plea to adopt Papiamentu as the language of education, but this has never been effected: neither under colonial rule (which in fact did not impose Dutch as the language used in education until 1936) nor after 1954, by the autonomous Antillean government. On the islands a bitter dispute persists concerning the question of whether primary education should remain Dutch-based or whether Papiamentu should be implemented instead. Alternatively both languages could be used. The local governments have never managed to make a clear-cut decision (an important practical obstacle for introducing Papiamentu as the first or second language in education lies in the lack of standardisation - Aruba and Curaçao have even chosen a mutually divergent orthography). Only in secondary and higher education is the formal status of Dutch relatively undisputed. On the English-speaking Windward Islands - situated in the English-speaking Caribbean - English has in fact dispelled Dutch, even in education, without any practical problems or discord.

Up until the late 196os the language issue seemed of little relevance to The Hague. During the seventies and eighties it was hoped, of course, that this would be a passing problem, with independence of the former colonies being imminent. Only by the 1990s, when it became apparent that this was not the case for the Antilles, were the subjects of education and language included on the agenda of Kingdom deliberations. Antillean autonomy in 
these affairs has remained intact so far, but one may doubt whether this will be sustained indefinitely. Meanwhile it may be instructive to look back in more detail at what policy there may have been for the Dutch language in the Caribbean during the last decades - if only to give an understanding of how the contemporary dilemmas of a multilingual Kingdom persist.

Shortly after World War II, the Christian democratic member of parliament E. de Kort made an earnest appeal to support the Dutch language and culture in the Caribbean. He affirmed that 'for our country, but surely also for the Antilles and Suriname, it is entirely desirable to continue using Dutch as the official language in education and to give the Dutch language a position as strong as possible in relation to domestic languages. ${ }^{4}$ However, such a mission civilisatrice, a deep-rooted and shared feeling that the Dutch language and culture should be spread overseas, was seldom spoken of in The Hague. Having said this, Dutch cultural influence in a narrower sense remained rather strong in the Antilles and Suriname, maintained by expatriates and local elites, and by their education systems, which had much in common with those in the Netherlands.

Over time, with autonomy, Dutch influence would dwindle and with it the use of the Dutch language. With this shift the language issue proved a delicate policy area for all parties involved. During the 1960 s Dutch members of parliament, especially of right-wing leanings, would from time to time advocate a strengthening of the Dutch language in the Caribbean. On the eve of the revolt in Willemstad, 30 May 1969, there was a predominant feeling that in the Caribbean there certainly was a place for Dutch and that this should be nurtured. Minister for Surinamese and Antillean Affairs Joop Bakker reacted against left-wing criticism regarding presumed cultural imperialism: 'I continuously ask myself, why should we now at much cost enforce upon these countries Spanish, Portuguese or English, if they themselves prefer to speak a different language?' To this he added a characteristic sigh: 'Dutch will be the official language for quite some time to come.' 5 This remark may well have surprised any Antillean listeners.

In the meantime, Dutch involvement in an expanding field of cultural cooperation would continue to grow, with increased financial input. This fitted well into the general tendency of an intensive policy of 'reciprocal assistance' under the Charter and was expressly supported in The Hague. However, there were no attempts to get directly involved in the overseas education systems. During the 1970 and 1980 s, in view of the presumed 'imminent' independence, the Netherlands held a rather open view regarding a future transition towards a different language in Suriname and the Antilles. Possible scepticism concerning alternative tongues was only worded with the greatest prudence. Now members of parliament generally liked to keep stressing the undesirability of enforcing Dutch, a perceived 'foreign' language, upon the islands. This implied an emancipation of Papiamentu, 
or allowing Spanish and English to develop - certainly more obvious choices in view of future sovereignty.

In general these views were endorsed by Dutch ministers, who at the same time clearly felt no desire to engage in any sort of language debate with Willemstad. When in 1980 Minister Fons van der Stee stated with 'considerable satisfaction' that 'in the first years of primary school the use of Papiamentu will continue on the Leeward Islands, and English on the Windward Islands', the social democrat Chris van Krimpen - personally well acquainted with the Antilles - was breaking with tradition and openly doubted whether in the short-term Dutch should be written off; a transition to Papiamentu he deemed unrealistic and he opposed 'politically correct' opinions which only served to endanger the education of the Antillean youth. With foresight he stated that a decision had to be made soon, 'otherwise the language problem will become unsolvable. ${ }^{6}$ Van der Stee acknowledged the dilemma, but would not take a stand. In the meantime there were talks between the countries regarding Dutch support of the Antillean and Aruban education systems. Yet throughout the 1980s the language issue would remain of marginal concern in Kingdom relations.

Dutch cultural policy in the Caribbean was therefore rather ambivalent. Apparently the decolonising Dutch showed little enthusiasm for a mission civilisatrice. At the same time the metropolis clearly favoured the Dutch, i.e. Western European culture in a broader sense, even if gradually more interest and understanding of Caribbean culture arose. Yet with the Dutch anxiously leaving initiatives regarding the central fields of education and language with the overseas governments, Dutch influence was mainly found in more direct cultural activities. Input on this level would never receive high priority in The Hague. This would remain the case during the latter quarter of the twentieth century, although the tide was beginning to turn in the light of two factors featuring high on the new Kingdom agenda: not only had the Dutch parted with the illusion of achieving Antillean and Aruban independence, but they were also confronted with a steadily growing migratory wave from the Antilles, especially from Curaçao. Eventually, during the 1990s, The Hague had no option but to open a broad cultural debate, focusing primarily on linguistic and education policies within the Kingdom.

This new approach was embedded with Minister Ernst Hirsch Ballin finally dispelling, in 1989, the notion of achieving independence, and at the same time connecting this not only to responsibilities in the sphere of good governance but also, more broadly, to a sense of being united in one Kingdom. Essentially this was a matter of breathing new life into a relationship where there was little true feeling of solidarity; from there tangible progress could be made. Caribbean administrators, as the conviction grew on the Dutch side, should feel more at home with Dutch culture, particularly in an administrative sense. Future island executives should be 
well-educated; following secondary education in the Netherlands presupposed a good start in the Caribbean. Potential Antillean migrants had to be familiar with the Dutch culture and have a thorough command of the language. In order to reverse the emigration flow, economic recovery on the islands was needed; essential to this end was a turn around in the deteriorating situation in overseas education. The conclusion drawn by Hirsch Ballin, and later also by his successors Joris Voorhoeve and Gijs de Vries, was clear. The Netherlands could and should get involved in Antillean and Aruban linguistic and educational policies; after all, the shortcomings thereof clearly also had direct and negative consequences for the Netherlands itself.

Even though Hirsch Ballin expressed the intention to continue respecting overseas autonomy, in his efforts to improve schooling on the Antilles he made it clear that the language issue could not be left aside and that he was not going to be swayed by island sensitivities, the reality being that ' $\mathrm{Pa}$ piamentu does not give access to the world outside of the three Leeward Islands'. ${ }^{7}$ During the continuation of his term the education issue would not be Hirsch Ballin's greatest charge, but it would still remain an important one. His 1993 policy memorandum Samenwerken op het terrein van Onderwijs ('Cooperation in the Field of Education') pervaded a spirit of deliberate involvement, whereby it was emphasised that the Dutch approach met with Antillean and Aruban wishes, and that it certainly was not the intention to oust native tongues. To the House of Commons Hirsch Ballin clearly described the linguistic implications of not transferring sovereignty. 'Within the perspective of independence, scope for the care of education was determined by that end goal of independence. Eventually the Netherlands would withdraw; 'it is "their" concern. Conversely, as part of continuing Kingdom relations, it is no longer only "their" concern, but also that of the Kingdom.' He stated that this required good education, not only to improve opportunities on the islands, but also to counter the problems that Antilleans had faced in the Dutch educational system. ${ }^{8}$

Minister Voorhoeve would continue to intensify this policy. Shortly after taking office he addressed the failings of the overseas educational policy. The first thing mentioned in this respect was the failure to concur on a political decision regarding the language issue. Although on Curaçao in March 1996 the three ministers of Education signed a Protocol for Cooperation, which outlined the Antillean and Aruban decision to maintain Dutch as the language in secondary education, the question regarding the position of Papiamentu in primary education remained unresolved. In the explanatory memorandum to the budget of 1997 Voorhoeve reiterated the importance of cooperation in the sphere of education, indicating this as 'a common concern'. Fuelling this issue was the problem of poorly educated Antillean immigrants in the Netherlands. 'Improvements in education', as the minister wrote, 'will remain an important focal point in the coopera- 
tion between the three parts of the Kingdom'. On other occasions, however, he was more outspoken, which prompted accusations of violation of the Kingdom Charter and even of neo-colonialism. ${ }^{9}$

Under Voorhoeve's successor, Gijs de Vries, education was defined - only upon parliamentary insistence - as a priority in development cooperation. Again, emphasis was laid on the poor command of Dutch among Antillean students, on the resulting underachievement in the Dutch-language education system on the islands, and on the consequences of this among Antillean migrants in the Netherlands. All this testifies to a growing understanding of the issues at stake. Yet, characteristically, to this day there has been no conclusive political debate on language options; once again politicians have pushed the whole issue aside - along with the debate on the suitability of Dutch in the Caribbean in the long-run. Neither have there been sufficient new investments in the Antillean education system, which thus continues to produce high numbers of drop-outs with little schooling and a poor command of Dutch. Bearing in mind the massive emigration rates among this disadvantaged group, it is remarkable that the discussions have not moved much beyond the still unresolved issue of whether these immigrants could and should be obliged - and at what possible sanction - to take an exam in elementary Dutch before settling in the Netherlands.

In the twenty-first century, accusations of neo-colonialism, it seems clear, no longer make an impression on Dutch administrators. However, the scope available to them to actively implement policies in the Antillean and Aruban educational fields remains restricted in view of the limitations imposed by the Charter, and by the simple fact that an assertive Dutch policy always provokes resistance, in particular where it concerns probably the most defining aspect of the Antillean and Aruban identity, and certainly the one which distinguishes the Caribbean Kingdom citizens most clearly from their metropolitan compatriots: language. That this language is not Dutch is the fruit of centuries of careless colonialism - French, English and Spanish have rooted more succesfully in the Caribbean and are disputed to a smaller degree than Dutch.

\section{Reciprocal Cultural Exchange?}

In its insistence on the three partners' preparedness to 'attend to shared interests and provide reciprocal aid on a footing of equality', the 1954 Charter singled out both economic and cultural exchange. Exchange indeed, with an insistence on a rather fictional reciprocity. There was a telling post-war prelude here. In 1948, at a time when the Dutch were finally beginning to face up to the inevitability of sovereignty for the Republic of Indonesia, the Foundation for Cultural Cooperation between the Netherlands, Indonesia, Suriname and the Netherlands Antilles (commonly known as 'Sticusa') was 
established in Amsterdam. Prime Minister Louis Beel attended this solemn occasion, as did his Minister for Overseas Territories J.A. Jonkman and sixteen Dutch intellectuals. The Sticusa had initiated from a private group of people with a strong interest and personal experience in the Dutch East Indies; none had any affiliations with the Caribbean. Nonetheless, central to Sticusa's statutes was the objective 'to bring about, on the basis of reciprocity, a harmonic development in a democratic sense between the four territories of the former Dutch empire', with 'an appeal to the full cultural involvement of the Netherlands'. Politics, so it was emphasised, had no part to play in Sticusa's activities.

The 'reciprocity' was defined as the aim to avoid 'one-way cultural traffic' and any 'self-interested and aggressive Dutch advertising for its own cause'. Still the self-imposed task of 'spreading the ethics of Dutch culture overseas' was almost inevitably coupled with an unadulterated paternalism. Sticusa chairman J.H.A. Logemann, former Minister of Overseas Territories, showed an unimpaired belief in the significance of the Dutch culture for the overseas territories: 'Language, religion, science, art, social and political views, brought and spread by the Netherlands in a Dutch fashion, a little more here and a little less there, are at present living elements of those [Indonesian, Surinamese and Antillean] societies. That does not disappear with our colonial power. That is the endowment of their new freedom.'10

It is also true for this part of the Dutch decolonisation policy that it was devised with Indonesia in mind and ironically this was precisely where it failed. The activities of Sticusa in Indonesia did not fulfil Dutch expectations. Moreover, the Dutch had hoped that the Indonesians would develop a similar organisation locally, but they did not: even if the nationalists may have felt any need for cultural cooperation, this would surely have evaporated as a result of the violent Dutch 'police actions' preceding independence.

Out of necessity, the Dutch cultural focus gradually shifted to Suriname and the Antilles. There, local Sticusa-based organisations were founded with the intention of promoting 'Western culture, particularly from a Dutch viewpoint'. Auditoriums were established, libraries expanded, films shown, schools of music founded and cultural experts flown in, all financed by the Dutch. There Sticusa developed the activities no longer appreciated in Indonesia. For many this was reason enough to cast doubt on the validity of the foundation, which gained even more weight in the context of a complete reappraisal of foreign policy with respect to culture. In the early $1950 \mathrm{os}$ Sticusa also lost much of its former high standing due to criticism levelled at the presumed extravagant size of its office in Amsterdam and the (over)spending of the budget. In the Dutch press and in parliament, regular complaints were made concerning dissipation of funds, insufficient effective governmental control, alleged left-wing (sic) sympathies or, on the con- 
trary, pandering to the overseas elites. Reproaches from all directions, which Sticusa was unable to sufficiently parry.

Eventually, in 1955, the foundation was disbanded and in 1956 a revised model was set up, this time focusing solely on Suriname and the Antilles, and operating independently of the Dutch civil service. This new foundation for cultural cooperation was again called Sticusa - a meaningful continuation. In the same paternalistic vein the goal was 'assistance in the furthering of culture in Suriname and the Antilles and maintenance of contact between these people and the Dutch and/or Western European culture'. This 'second Sticusa' operated under the ruling of the Charter with its insistence on autonomy and reciprocity. With Suriname and the Antilles attaining autonomy they were free to follow their own cultural policies in the broadest sense of the word; the Dutch role was restricted. For members of the 'Sticusa old guard' the 'West Indies' were no more than a consolation prize. The initiators of the first foundation had been more or less forced to include Suriname and the Antilles in their activities. Now all the work had to be focused on these countries considered less important, and not only that: in this 'new' Sticusa Indonesian experts were calling the shots once again, at least to start with. It is striking that local cultural organisations and the Surinamese and Antillean goverments apparently harboured no decisive objections against the new construction, which after all was a repackaging of the same product. Initially only 'radical minorities' would speak out against Sticusa, but before long criticism would be more widely shared.

During the first years of the new Sticusa, cultural cooperation was seldom the subject of conversation in the Dutch Council of Ministers. In parliament, however, it was discussed annually during the preliminaries to the national budget. At first this was mainly positive, even though regularly critical remarks could be heard on the efficiency and costs of this 'body swallowing millions.' ${ }^{11}$ Not until 1960 was it necessary for the Council of Ministers to look more deeply into cultural cooperation. Despite some initial practical objections it was soon agreed that due to overseas dissatisfaction with the lack of control on Sticusa's activities, the governments concerned should decide on long-term cultural planning themselves, instead of leaving this to the foundation.

Thus, on the initiative of the Antilles, on 2 February 1961 Queen Juliana installed the 'Advisory council for cultural cooperation between the countries of the Kingdom'. The Queen greeted this council 'with gratitude', stating that: 'One of the opportunities offered by the Charter has been seized proof that it is truly living within the three countries. ${ }^{12}$ The council would have the task of advising the three governments on the coordination of cultural exchange within the Kingdom and the long-term plans for joint cultural activities. The council was also to advise on cooperation with different countries and on the Kingdom's representation within international cul- 
tural organisations. Strikingly it would be Sticusa functioning as the secretariat of this advisory council.

This new institution soon fostered mixed reactions: although it had been established on the initiative of the Antilles, in Surinamese nationalistic circles distrust dominated. This is not surprising. The advisory council was attempting to dispel a feeling of general overseas dissatisfaction which had obviously not been achieved. As early as 1960 it was clear that this 'second' Sticusa had not created a comfortable situation for Suriname and the Antilles. Even though the foundation had substantial means, cultural exchange was subordinate to development aid by far; also local cultural activities and cultural centres were highly dependent on financial aid by Sticusa. In this light it became ever more doubtful whether it had been a good choice to imbue a Dutch foundation with the millions of guilders destined for cooperation. The new advisory council did create the possibility of subjecting cultural cooperation within the Kingdom to political control by the three governments. Yet the original Antillean objections (supported by Suriname) that had lead to this initiative, namely 'the feeling that in their countries cultural policy is to a greater extent determined by the Sticusa board in the Netherlands', would remain, also after the installation of the advisory council.

In the meantime, the Dutch did not seem, at least not in the first instance, to have been overly bothered with the question of whether this was - and whether this was allowed to be - a matter of paternalism or cultural imperialism. Talks rather centred on questions such as whether the organisation was efficient and whether the Dutch tax capital was being spent in a responsible manner. During 1970 Sticusa was the subject of overwhelmingly negative reports in the Dutch press that would greatly damage the foundation. Fundamental problems were broached regarding the executive committee, the management and the costs of the foundation. On top of this came rather ambivalent criticism with respect to content. On the one hand the foundation was being reproached for lacking a cultural vision and not daring to follow a policy 'fearful of being labelled colonialist', and on the other hand Sticusa was accused of 'patronising'. The foundation was unable to parry the criticism, feeling 'it could never do anything right'. Clearly its position was not only weakened by the criticism from Suriname and the Antilles, but also from the Dutch politics and press. There were attempts to improve its image, but with the damage already done Sticusa would always be fighting a losing battle.

When in 1975 sovereignty was transferred to Suriname, the nationalist government found that neither Sticusa nor the advisory council had ever shed their neo-colonial character. The advisory council would make a vain attempt at continuing cultural cooperation, but the Republic of Suriname had no desire to continue in this direction. The statement attributed to the Surinamese Minister of Education and Culture of the day - at present the 
President of Suriname - Ronald Venetiaan, clearly defined feelings toward Sticusa in Suriname. He was alleged to have said: 'And now bugger off!' Similarly, Premier Henck Arron would make it very clear that after independence Sticusa was no longer welcome in Suriname, as he announced that the cultural relations would be following new lines, on the same basis as cultural treaties signed between the Netherlands and several other countries. On 5 February 1976 such a Cultural Treaty between the Netherlands and Suriname was indeed signed, whilst Sticusa and the advisory council had to restrict their field of activity to the relations between the Netherlands and the Antilles.

And so Sticusa continued its activities in 1975 with its field of operations further narrowed, and now facing the uneasy task of dispelling its neocolonial image. Thus it affirmed 'that policy will be made over there, not here'. Yet eloquent critics such as literator and former governor Cola Debrot and author Frank Martinus Arion would persist in their plain disapproval. In the words of the latter: 'On this island [Curaçao] we were in fact saddled with a Ministry of Culture in Amsterdam. Cultural life here was regulated by Sticusa, in other words: by the Netherlands and by the Dutch.' In Dutch parliament the social democratic spokeswoman for the Antilles, Wijnie Jabaaij, liked to speak about Sticusa in terms of a 'decrepit elephant'. ${ }^{13}$

It was the 'Gemengde Commissie van Deskundigen' (bilateral commission of experts) that in its 1979 report Aanzet tot een integraal beleidskader regarding the socio-economic development of the Antilles faced the problems head on. The commission felt that the Antilles itself invested 'shamefully little' in (socio-)cultural work and that 'from the viewpoint of a focused cultural policy and a sound development of this work' it was undesirable 'that it was Sticusa that to a great extent was supplying the funds'. The commission therefore pleaded for transferring the larger part of the Sticusa funds to the Antilles, only then could an independent policy be followed. Minister for Antillean Affairs van der Stee was in complete agreement: 'Full responsibility for this policy should lie in the Antilles itself and Dutch involvement in this area should end.' ${ }^{, 14}$

Ironically enough, this time in the Antillean press reports were issued stating that the imminent disbanding of Sticusa was a meddlesome act by the Netherlands, presumably showing nothing but contempt for Antillean parliament. However, the new Minister for Antillean Affairs Jan de Koning was not to be held back by this; shortly after his appointment he tried to transfer part of the Sticusa money directly to the island governments. Eventually a transfer in phases was decided upon. For some time, the future of the contracted Sticusa was in doubt. Within the foundation's management circles and the cultural advisory council it had been thought that they would continue, in one way or another. But de Koning decided otherwise. In the summer of 1987 he announced that as of 1 January 1989 Sticusa would be disbanded. On 15 October 1987 a Cultural Treaty was signed in 
which there was only mention of a tripartite cultural commission; Sticusa was not referred to. In this whole process Sticusa itself had been a rather submissive victim. Management and employees had realised that their backs were against the wall and were resigned to the inevitable. The foundation had been indissolubly connected with a past which had to be parted with.

The subsequent history of cultural exchange within the Kingdom has not been particularly inspiring. The budget for cultural development aid was allocated to two newly established Antillean and Aruban organisations. The Antillean organisation OKSNA received a devastating evaluation in the mid-199os for operating inefficiently, along clientelist lines and without a clear vision. Under Dutch pressure the Antillean government then decided that ОкSNA would be substituted by a new foundation distanced from local politics, a measure which took nearly another half decade to implement. Meanwhile The Hague itself developed few initiatives in the field of cultural cooperation. A new Cultural Treaty in 1997 did not do much to alter this state of affairs. After an abortive attempt in the last days of Kabna to initiate a Dutch council to deepen cultural exchange, the matter was virtually put to rest under the Ministry of the Interior and Kingdom Relations. The new State Secretary Gijs de Vries' policy report Toekomst in Samenwerking (1999) did not dwell on cultural cooperation, and this has not changed since. Presently, the budget allocated to cultural exchange is minimal in comparison to the previous budgets of Sticusa, the one major exception being Dutch support for the National Trust for the restoration and preservation of historical buildings. Of course, here the relative absence of ideological implications dovetails nicely with the tourist potential of the cultural remnants of colonialism.

\section{A Comparative Perspective}

The Caribbean has often been defined as one cultural area, divided by a history of colonisation by different states with each leaving its own cultural legacy, yet drawn together by a shared past of plantations, slavery and indentured labour, and subsequently mass migration. As we indicated at the opening of this chapter, there are substantial differences in the weight of the cultural and particularly linguistic legacy left by the former colonisers.

Post-war French policy for its remaining French territories has been consistent, and reflected a decision for a permanent presence and the willingness to bear the full consequences, even at considerable cost. The ambivalent economic results of this policy are evident in the tension between relatively high standards of living on the one hand and total dependency and high migration rates to the always more prosperous metropolis on the other. Culturally, the départements d'outre-mer have an extremely ambiguous 
identity, the perennial debate both among cultural elites and in everyday life being the articulation between metropolitan and creolised culture. Facing substantial emigration of the local population and, at the same time, immigration from the metropolis, the French Caribbean runs the risk of 'genocide by substitution', as Aimé Césaire already foresaw some three decades ago. Combined with the continuous boom of the tourist industry, the French Caribbean islands are caught in a process one might well characterise as 'Hawai-isation'. ${ }^{15}$ Having said this, there is little doubt that French educational and cultural policies have been rather successful if measured by the command of French in the overseas departments and among the Caribbean migrants in the metropolis, and even in terms of transatlantic cultural affinity. This remains the case even if most citizens from the Caribbean Doм 'do not feel fully French. Nor, of course, do most Frenchmen consider them to be. At best, they are Frenchmen-with-a-difference, in part because of the racial discrimination they confront at every turn [in France]. ${ }^{36}$

While vacating most of the region in the post-war period, the United Kingdom left the former British West Indies its language, democratic institutions and a now fading educational orientation. The United States has long since taken over the British position, both as an informal post-colonial power and as the recipient of the greater part of the Anglophone Caribbean migrants. It is interesting to see that even in the remaining British Overseas Territories educational, cultural and migratory orientations are definitely not limited to the constitutional metropolis. In terms of language choice, of course, there is no serious ambiguity between either an American or a British orientation, but rather between creolised and standard English. Yet no Anglophone Caribbean government, whether sovereign or not, has seriously considered using a local Creole as the language of instruction. In the words of former St. Lucian Prime Minister John Compton, 'Konpyouta pa ka palé Kwéyol', computers do not speak Creole. ${ }^{17}$ This means, among other things, that education remains embedded in an American or British tradition and that migrants from these territories have distinct advantages over other Caribbean migrants in the United States. ${ }^{18}$

Spain, sending by far the largest number of migrants to the region, left a considerable population of peninsular origins, along with its language and much of its culture in the Caribbean. Once the Spanish colonies were lost, they too were quickly incorporated into the American sphere of influencein the case of Puerto Rico as a full-fledged colony. Even so, the Spanishspeaking Caribbean tends to define itself as part of the Spanish Americas as a whole, defined through language and a shared historical legacy. Over the past decades, Spain has somehow managed to capitalise on this goodwill, with the United States overshadowing the earlier Spanish colonisation. In Puerto Rico this cultural competition between two colonial legacies has produced a culture of conflicting orientations, with a total constitutional 
and migratory incorporation into the United States, yet a linguistic and cultural situation in many ways similar to the one prevailing on Aruba and Curaçao - including a long history of serious educational and linguistic problems of the Puerto Rican community in the United States, and deep ambivalence among Puerto Ricans both on the island and on the mainland regarding American culture and politics. ${ }^{19}$

Particularly for Curaçao, the parallels with the Puerto Rican case are too obvious to ignore. As has been discussed in the previous chapter, since the 1990 s the Curaçaoan exodus to the Netherlands has overshadowed all debates on Kingdom relations - in fact this migratory wave has put the Dutch Caribbean on the metropolitan agenda again after a period of relative neglect. The debates now centre on both the reasons for Antilleans leaving and on the problems many of them face in the metropolis. Poor education, poor command of Dutch and little knowledge of and affinity with Dutch culture are widely perceived as problematic. As may have become clear from the preceding pages, Dutch neglect and an unduly high consideration for Caribbean autonomy against better judgement have had their share in bringing about these very problems which now take their toll both on the islands and in the metropolitan cities.

Over the past decades, the once enormous distance between the metropoles and the former colonies has evaporated, geographically, physically, psychologically. Nearly half a million Dutch of (partly) Caribbean origins have brought some of the colonial history home. For those still living in the former Dutch Caribbean, the Netherlands has increasingly become a tangible reality. So yes, there is more of a transatlantic cultural affinity than ever before. But this has not come about through any well-planned Dutch cultural or linguistic policy. Paradox has it that this is rather the unexpected and, from The Hague's point of view, unsolicited consequence of the failure of previous centuries of colonisation and decades of decolonisation. One wonders whether at any point this realisation will stimulate Dutch politicians to start formulating a more engaging cultural policy for their transatlantic Kingdom. And one questions the chances that their Antillean and Aruban counterparts will become more prepared to openly discuss such delicate matters, worrying as much about their undereducated populations at home and their permanent expatriates in Europe as about their own precious cultural autonomy. ${ }^{20}$ 


\section{Epilogue}

At the outbreak of World War II the days of classic colonialism in the Caribbean had long since passed. By then, the classic decolonisation process had also come to an end. Around 1800 the slaves in the French colony of Saint-Domingue had not only successfully gained their liberty from the local planters, but they had also become independent from the distant mother country. A unique history: Haiti was the second nation, after the United States, to break with its metropolis; the first state not governed by white Europeans or their descendants; the first state to abolish slavery. Around 1900 Cuba had liberated itself from Spain after four centuries of colonial regime. In the intervening century Santo Domingo, the neighbouring country of Haiti, had also struggled from Spain's grasp to become the sovereign Dominican Republic. In many respects Haiti had led the way in the modern history of the Americas. The Dominican Republic and Cuba were already lagging behind in this regional pattern - all other Latin American countries had thrown off the colonial yoke at an earlier stage. The first three Caribbean nations shared a classic pattern of colonialism and decolonisation. To their mother countries they had been of eminent importance. Both France and Spain had waged bloody and costly wars in the vain hope of preserving these colonies. This chapter of history had long since ended by 1940.

In the English-speaking Caribbean of the 1930s, political parties gradually evolved from the trade unions and demanded more influence in their local administrations, but powerful independence movements were not formed. In Puerto Rico, which in an astonishing example of modern colonialism had been taken over from Spain by the United States, there was much aversion and silent cultural protest against the yankis, but a well organised, influential independence movement failed to evolve. The same goes for the French Caribbean. The ideology of négritude, partly spread by black intellectuals such as the Martiniquan Aimé Césaire was developed in Paris, not in the colonies, and lacked a political programme. In the Dutch Caribbean only a handful of people demanded independence. One of these was the Surinamese Anton de Kom, who developed his ideas mainly in the metropolis, where he was living. When he returned to Suriname in 1930, the Dutch colonial authorities made sure to expel him as soon as he started to organise anti-colonial protests. Once he had literally been put on a oneway boat to Amsterdam, nothing more was heard about an independence movement in the Dutch Caribbean until after the war. 
World War II was a decisive period in the modern history of colonialism and decolonisation worldwide. As unwelcome as it may have been to The Hague, this also applied to the Kingdom of the Netherlands. Under strong pressure from the Indonesian independence movement and an international opinion led by the United States, the Netherlands had to accept a redistribution of power. For too long the Dutch persisted in the hope that this would take place within the Kingdom - a costly illusion indeed. The Republic of Indonesia, which had unilaterally declared itself independent in 1945, was finally accepted by the Dutch in 1949, after much bloodshed and Dutch foot-dragging, leaving a legacy of mutual distrust which would cast a long shadow in the decades to come.

The other European colonial powers had also resisted the crumbling of their empires by exploiting all means at their disposal, including their military might. It became all too clear in Asia in the 1940s that this was to no avail. This realisation led the way to a new approach to the decolonisation process, resulting in many African countries gaining independence in the 1960 with the full cooperation of their former colonisers. Classic colonialism had clearly come to an end and, along with it, the classic decolonisation process, in which only through armed conflict would a colony gain its independence.

In the post-war Caribbean this process was given a new dimension. ${ }^{1}$ Once cherished as the 'darlings of empire', the colonial possessions had turned into economic millstones. The question now was how to construct a postcolonial policy in this context? Two of the four colonial powers concerned, namely the United States and France, felt a strong need to remain present in the region for strategic reasons. Considering the Caribbean its own 'back yard', Washington attached vital importance to maintaining a presence, particularly in a military sense; this geopolitical wish gained strength after Cuba had become the antithesis of the American dream by Fidel Castro's assumption of power in 1959. Neither did France hesitate to prolong its Caribbean presence. Wherever this was possible Paris wanted to give acte de présence in the vain hope that it could perpetuate the former empire with its grandeur and political and cultural influence on the world stage.

The policies of the other two remaining colonial powers, the United Kingdom and the Netherlands, showed less involvement. From the start, London had given its full cooperation in the transfer of sovereignty to its West Indian colonies. Initially the British had sought to emancipate this heterogeneous conglomerate altogether, in the form of a self-governing federal state. However, since the West Indian Federation failed at an early stage, due to differences and rivalries between the island communities, the United Kingdom wholeheartedly cooperated with the acquisition of individual independence by the (is)lands. In the 196os, the larger Caribbean colonies - Jamaica, Barbados, Trinidad and Tobago and Guiana - pushed for this initiative themselves. In the course of the 1970 and 1980 os the 
British government became increasingly impatient and wanted to grant independence to the remaining islands, in which it no longer had any interest. As far as Westminster was concerned, all of the former British colonies had to go. The fact that at present a handful of Caribbean 'Overseas Territories' still come under the sovereignty of the United Kingdom should not, therefore, be attributed to the ardent wishes of Westminster, but rather to the stubbornness with which these islands have refused to accept independence. 'Decolonisation upside-down' appears to be a suitable characterisation.

As a group the non-sovereign Caribbean differs significantly from the majority of constitutionally independent countries in the region. At the same time, this group shares many characteristics with the worldwide group of contemporary overseas territories scattered around the world. It is no coincidence that most of these so-called 'confetti of empire' are small islands. Yet apparently such similarities have not dictated a uniform style of post-colonial rule. In fact, as Aldrich and Connell remark in their study The Last Colonies, 'the reasons "colonial" powers acquired and retained such outposts, and the ways in which they administer them, adhere to few general processes of history or politics'. ${ }^{2}$ In the same vein, historical contingency rather than any grand design for the most part explains the constitutional heterogeneity of the Caribbean and, to a lesser extent, the permanence of a transatlantic Kingdom for the Netherlands.

\section{Dutch Caribbean Decolonisation in a Nutshell}

The constitutional basis of the present transatlantic Kingdom - the 'Charter for the Kingdom of the Netherlands' - had in actual fact been designed during World War II with the specific purpose of winning over nationalist opposition in the major Dutch colony of Indonesia, thus enabling the formation of a supposedly permanent, 'post-colonial' alliance. The knock-on effect of the many concessions made to Indonesia would ultimately benefit Suriname and the Netherlands Antilles. Gradually it became clear that the offer of these privileges was irrelevant to the Indonesian nationalists, whereas in Paramaribo and Willemstad they were warmly welcomed. All of this culminated in the 1954 Charter, today still the highest legal order within the Kingdom. Confirmed within it is the principle of 'master in one's own house', for which the political elites in the territories had been striving, while the Kingdom remains responsible for prime affairs of shared interest, especially foreign affairs, defence, nationality, and the guarantee of good governance and fundamental human rights.

The Charter was, and is, not without its flaws. There is the fiction of 'equality' and of 'mutual assistance' for the three countries, of which one, the Netherlands, occupies a dominant position. There is the unresolved 
tension between local autonomy and the obligation of the Kingdom to guarantee good governance, but without the clear definition of a structure for its practical implementation. There is the democratic deficit of a Kingdom government which cannot answer to a corresponding parliament on that level. And finally there is the simple truth that the Netherlands is of eminent and even increasing importance to both Caribbean countries whereas, in reverse, this is not at all the case; not economically, not politically, and not culturally.

Nevertheless, between 1954 and the end of the 1960s, the Charter functioned as a satisfactory regulation for a Kingdom consisting of three countries that had rather little to do with each other, and therefore enabled a somewhat inconsequential respect for one another's autonomy. A contented member of Dutch parliament remarked in 1964 that the Charter could count as 'an example' to the world. Five years later this satisfaction turned into discord. The Curaçaoan revolt of May 1969, and the Dutch military assistance requested and granted on the grounds of the Charter, formed the immediate cause. Particularly in view of its image on the international scene, the Netherlands found its ultimate political responsibility for the autonomous Caribbean countries increasingly problematic. Within a few years Dutch politics swung round, and the striving for a full completion of the decolonisation process, understood as the transfer of sovereignty to Suriname and the Antilles, became a policy target supported by a clear majority of Dutch parliament. With two politically like-minded cabinets holding office in the Netherlands and in Suriname in 1974-1975, an agreement was made resulting in the Dutch flag being lowered in Paramaribo and that of the Republic of Suriname being hoisted on 25 November 1975. In hindsight it can be concluded that the haste with which the requisite proceedings had taken place was not in accordance with the elementary criteria of good governance. The announcement of the transfer of sovereignty also marked the beginning of an exodus from Suriname to the Netherlands, which was a major setback for a Republic yet to come into being. Paralysed, The Hague watched events unfold.

The Surinamese exodus would continue, whilst the economic and political developments of the Republic caused increasing concern. During the many years in which the Dutch government remained strongly involved with Suriname, the newly acquired sovereignty often appeared to be an illusion. Since in recent years the Dutch government has started to turn away from its own Caribbean creation, Suriname's independence is under strong pressure from other quarters. The warning of the Surinamese Staten member Biswamitre, expressed in 1960, springs to mind. He considered it unlikely that his country would ever become independent, but predicted that in this event it would either have to accept a new colonial relationship, this time under Brazil, or have to crawl back to the Netherlands.

In the early 1990s, Suriname's return as a 'Kingdom-partner' has ap- 
peared only once on the Dutch political agenda, but was almost immediately - and probably for all time - rejected both in The Hague and Paramaribo. This was followed by mutual ambivalence and an oscillation between political advances and distancing. Brazil, as ever, is watching patiently from the sidelines. Meanwhile, the emerging threat of criminal globalisation has inflicted serious but, as it is hoped, not fatal damage to the young Republic of Suriname. However, the continuing history of the new Republic falls outside the context of this book, which focuses on the relationships within the Kingdom. ${ }^{3}$

In 1975 the Kingdom was reduced to two partners, the Netherlands and the Netherlands Antilles. Developments in this relationship have been remarkable. Until 1990 the Dutch government did everything possible - although as time passed with less vigour - to complete the dismantling of the Kingdom. A responsibility for possible negative consequences of policies made by the autonomous Antilles did not form the only motive for this striving for 'complete decolonisation'. Two other considerations became increasingly prevalent. There was growing dissatisfaction with the apparently failing, yet vastly increased development aid, which did not lead to economic growth and self-sufficiency. In addition, there was the fear of another exodus, this time not from Suriname but from Curaçao; a spectre that to a certain degree would become a reality in the course of the 1990 .

In the Antilles major public support for the acceptance of independence has never materialised. Even if The Hague had wanted this, the Charter does not allow for the imposition of independence on the islands against their own will. Through decade after decade Antillean and Aruban administrators have made clever use of this fact. However much the Dutch insisted, they simply refused to cooperate. The Hague finally accepted its own impotence in this situation, imposing a new set of conditions instead: if the Antillean islands were to remain part of the Kingdom after all, they would have to bring their policies more into line with those of The Hague. Not without reason the islands feared an assault on their autonomy. Since the 1990s, the transatlantic relations have indeed been characterised by constant political bickering, sparked by the Dutch, regarding the boundaries between local autonomy on the one hand and overall responsibility of the Kingdom on the other. Again the Caribbean players used their bargaining position cleverly. In the apt metaphor of the influential Curaçaoan writer and essayist Boeli van Leeuwen: every time the Dutch laid out the game of chess, their Antillean and Aruban opponents hurried to pull out their game of dominoes instead.

By then there were again three Kingdom partners. With the approval of the Dutch and Antillean governments, Aruba obtained the desired separate status as a country in its own right in 1986, apart from the Antilles but within the Kingdom. This approval conflicted with the policies pursued by The Hague and Willemstad since World War II. The sanction imposed on the 
separation of Aruba was that of a complete transfer of sovereignty ten years later. This would not be carried out. Instead, in 1996 Aruba's status aparte within the Kingdom was made permanent. With this the door has been opened towards a further fragmentation of the Antilles.

\section{Caribbean Decolonisation: a Tentative Balance Sheet}

Now at the beginning of the twenty-first century what assessment can be made of Caribbean decolonisation? To begin with, we can compare the independent Caribbean states with the non-self-governing territories in the region. This reveals a sobering picture, making it understandable why the Antilles and Aruba, nor any of the present other non-sovereign territories, have ever demonstrated a significant interest in acquiring political independence. Of the total population of the Caribbean, an estimated 37 million people, almost fifteen per cent live in areas which still maintain constitutional ties with the mother country. Numerically the most important of these is Puerto Rico (3.8 million inhabitants), followed by the French Caribbean départements d'outre-mer (DoM, approximately 1 million inhabitants), the Netherlands Antilles and Aruba (270,0oo), the British Overseas Territories $(155,000)$ and finally the U.s. Virgin Islands $(110,000)$. These territories form a remarkable exception in their region, since after Haiti, the Dominican Republic and Cuba, more than a dozen mini-states - most of the former British colonies and Suriname - also acquired independence in the post-war period.

Despite earlier expectations, there is no indication that the remaining 'not yet' independent Caribbean (is)lands will opt for political independence in the foreseeable future after all. This comes as no surprise, as sovereignty has a high price. These non-self-governing territories may in many respects be less developed compared with their mother countries, but within their own region they make up the leading group of most privileged states. Roughly speaking, their inhabitants, in comparison with the inhabitants of independent Caribbean states, enjoy a higher standard of living. Furthermore, direct political relations with the mother countries provide guarantees in the spheres of fundamental human rights and freedoms and 'good governance'; the inhabitants of these non-self-governing states also enjoy the right of abode in the metropolis, a right intensively made use of. In a material sense, then, it can be argued that the non-sovereign Caribbean has the best of all worlds - yet this is largely at odds with nationalist thinking. Lone fighters for sovereignty argue that the persistence of 'neo-colonial' dependence insults the dignity of their compatriots and prevents them from grasping the challenge of developing their own country. Not surprisingly, nationalist ideology anywhere in the non-sovereign Caribbean is loaded with ambivalence towards, and even resentment of the ever-present 
metropolis. Such ambivalence pervades everyday discourse in 'colonies' such as Martinique, Puerto Rico and Curaçao. ${ }^{4}$

Yet those arguing for a definite break with the colonial past remain isolated. In various Caribbean (is)lands there have been plebiscites and polls to establish the population's opinions concerning political status and development of their countries. It is remarkable that this has hardly ever happened in countries that were preparing for possible independence. Official referendums were only organised in Puerto Rico, the U.s. Virgin Islands, Bermuda, Aruba and the Netherlands Antilles. Besides this, quite regularly there are and have been small-scale opinion polls. Invariably, where the option was available, the outcomes were that people in the non-sovereign Caribbean opt en masse for continuation of the non-self-governing status. ${ }^{5}$ An organised voice for independence is seldom heard. These results give evidence of an awareness, particularly for micro-states, of the futility of sovereignty in a globalising world set against the tangible advantages that 'dependence' offers. Given the often dire situation in those Caribbean countries which did become independent, a strong will to remain associated with the metropolis persists.

In 1998, in the Dutch Caribbean territories a large-scale enquiry was conducted, Ki sorto di Reino?/ What kind of Kingdom?, ascertaining the opinions of the Antillean and Aruban populations. This inquiry reaffirmed the awareness that independence is no longer seen as the only logical outcome of decolonisation. ${ }^{6}$ Overwhelming majorities on all islands indicated no interest in a transfer of sovereignty. Primarily pragmatic motives underscored the Antillean and Aruban wish to remain within the Kingdom: a Dutch passport; free migration to the Netherlands; economic assistance; Dutch protection of the territory, and the functioning of democracy and the judicial system. Cultural affinity, on the other hand, proved of minor relevance.

What about the internal differences within the category of non-self-governing Caribbean states? The metropolitan approaches to these post-colonial relationships differ, and one wonders which construction is the most successful from the point of view of the parties involved. A comparison on the basis of the previously mentioned criteria is relevant to answer this question.

Puerto Rico, the Dutch Antilles and Aruba enjoy a relatively high degree of autonomy. At the same time Washington has maintained more decision making power over Puerto Rico's internal affairs than the rather more liberal Dutch government has vis-à-vis the Antilles and Aruba. Nonetheless, since the beginning of the 1990s, informal Dutch involvement with the Antillean and Aruban governments has increased considerably. Perhaps the French construction of départements d'outre-mer could be labelled as the most 'neo-colonial' of all models under discussion, since the départements definitely have a low degree of self-rule compared with the American, Dutch, and even the British territories in the Caribbean. ${ }^{7}$ On the other hand the dé- 
partements d'outre-mer have some formal influence in metropolitan affairs; through the electoral process the Dом are directly represented in French parliament. The French centralistic style of government which in a Caribbean context may appear 'colonial', equally applies to its French departments at home.

In the domain of civil rights and freedom of migration to the metropolis, it is the French government that has pursued the most liberal and integrative policies. From an early stage, all inhabitants of the vieilles colonies in the Caribbean have enjoyed the same political rights as those within the metropolis; they are French citizens in every respect, which means that they enjoy the right of abode in the metropolis, along with a full vote in French general and presidential elections. The Dutch and American governments also have pursued a policy of free immigration from the Caribbean territories, but only give the right to vote to those who take up residency in the metropolis. In the British model, until recently there was no place for 'equality'. Instead, in the 196os, the West Indians became subject to a system of 'second class citizenship'. Only since the transfer of Hong Kong with its population of six million to China in 1997 has the United Kingdom moved towards full citizenship and free access to the mother country for individuals from the British Overseas Territories. In accordance with the British government's White Paper of March 1999, British citizenship (and so the right of abode) has been offered to those people of the Overseas Territories who did not already enjoy it. In this context it is ironic that at the same time Dutch politics, in reaction to the sharp increase in migration from the Antilles, started considering - although not implementing in the end -stringent immigration rules with respect to fellow citizens from the Caribbean.

Of all the mother countries, the French government is the most willing to give financial assistance to its Caribbean territories; per capita this ranges from $\$ 2,900$ to $\$ 3,800$, including the European contribution. This is followed by the United States, which spends some \$2,500 per capita on Puerto Rico, and $\$ 1,000$ on the U.s. Virgin Islands. In comparison, with \$ 500 per capita, Dutch financial help for the Antilles and Aruba is anything but excessive - a little known fact within the Netherlands. Again, the British government appears to be the most reserved; only three OTs receive aid, more or less at the level of Dutch per capita transfers. ${ }^{8}$ On the other side of the coin, however, the substantial financial contributions by the metropolis, in general leading to a relatively high standard of living in the Caribbean territories, also tend to lead to a strong dependency on these contributions, with the result that economic development is perhaps hindered rather than advanced. In the French overseas départements and in Puerto Rico, this dependence on payments from the metropolis is the strongest, whereas the British Overseas Territories are quite self-sufficient. The Netherlands Antilles take up a middle position in this respect, while 
Aruba has made tangible progress towards diminishing dependence on development aid.

The realisation that metropolitan transfers, while supporting relatively high standards of living, have in most cases also cemented dependency, is very much at odds with the neo-liberal policies which have prevailed in international economics since the 1990s. The British, but increasingly also the Dutch, have applied these policies in their economic relations with their overseas territories. For American, and certainly French policies, this is much less the case. Yet in American discussions on the status of Puerto Rico over the past decades, one observes increasing discontent with a costly and essentially protectionist relationship. One wonders how long Washington will be prepared to uphold this relation, and even more how long Paris will be able to single out the ром from the prevailing European neoliberal policies. ${ }^{9}$

In the cultural sense, France - in some ways with success - has pursued the most 'colonial' policy. Compared with the other three 'models', the cultural gap between the Caribbean territories and the mother country is much smaller in the départements d'outre-mer than anywhere else in the region. Puerto Rico, the Antilles and Aruba use their own languages, which indeed boosts local identity but at the same time also widens the gap with the mother country. In the context of the extensive migration taking place, this results in severe problems for both the individual migrant and the receiving mother country.

Given the diversity of the different constitutional models, a definitive and all-embracing answer is unobtainable; it is also unrealistic to make a value judgement as to which model is the most successful. It is not only the complexity of the argument which makes this impossible, but also the fact that any judgement is inevitably normative, in the sense that one would have to weigh up the four different dimensions and decide which ones are the most important. There is no such thing as an impartial yardstick to measure the relative weight of material gains (as in financial aid, a metropolitan passport and the right of abode) against the value of genuine sovereignty and an 'authentic' cultural identity - or better, to stay away from essentialist claims, at least a national identity, not essentially dependent on a metropolitan model. Nor is it a given fact that guarantees of good governance and the protection of human rights and liberties are really contingent upon some outside constitutional tutelage - after all, against the troublesome historical record of states such as Haiti, the Dominican Republic and Cuba or, more recently, Guyana and Suriname, we have the commendable counterpoint of most of the sovereign Commonwealth Caribbean.

Furthermore, there is the factor of perspectives. Freedom of migration, for example, may be deemed crucial to the individual Caribbean migrant who will therefore be satisfied with a metropolitan passport and the right of abode, whereas in the metropolis this may be experienced by locals as an 
aggravating factor in social issues. In the Caribbean territory involved, freedom of migration to the metropolis, while leading to a thinning out of the social underclass, often also involves the loss of professionals which can only be detrimental to the sending community.

In short, any answer to the question as to whether one model or the other functions more successfully implies some clarification in perspective: for the metropolis, for the Caribbean territories, or for the substantial number of Caribbean citizens who have emigrated - or are planning to emigrate to the metropolis. Again, there are no easy answers, nor can the diverging of perspectives on how to proceed be reduced to simple clashes of interest between metropolitan centres and dependent territories. Thus much of the most recent clichés about a presumed Dutch incompetence to implement a decent decolonisation policy actually boil down to two familiar complaints: 'too much money is being spent on the Antilles and Aruba' and 'they continue coming our way despite all our help' - issues not likely to cause major concern on the islands. Yet the question as to whether decades of financial aid have in the end only aggravated dependence and clientelism should worry anyone concerned with these small-scale Caribbean societies - irrespective of nationality, ethnicity, place of birth or residence.

\section{What Kind of Kingdom?}

All the same, it has to be concluded that, for the most part, these four groups of Caribbean territories, despite their differences, share similarities which differentiate them from the independent nations of the region. What they share are the crucial advantages of a stable post-colonial political relationship as well as a deeply rooted ambivalence about this relationship; a 'mother country' that is considered indispensable, but at the same time often regarded with suspicion and resentment. The non-sovereign Caribbean countries, if only too well aware of their small size and vulnerability, invariably deplore the lack of patience and respect from their indispensable partners.

During the 1990 in the Antilles and Aruba this ambivalence grew as Dutch involvement and - literal - Dutch presence increased on the islands. Inescapable as the constitutional and increasingly also demographic ties with the Netherlands may be, the atmosphere of administrative consultations is invariably tense and characterised by political bickering. The Caribbean argument that 'the Netherlands is impeding our autonomy' was always playing a main role. An outsider could be surprised by this state of affairs. After all, none of the dependent territories in the Caribbean has been granted the same level of autonomy as the Antilles and Aruba. However, ever since the 1990s, the fear of restricted autonomy has become a major concern for Caribbean politicians. It is one thing to secure the best deal, it is another to hold onto it. 
The position of Antillean and Aruban politicians has always been clear: a limitation of autonomy is a subject beyond discussion. Hence the deadlock in the negotiations on the amendment of the Charter. It is less clear whether the island populations are of the same opinion. The previously mentioned poll, Ki sorto di Reino? revealed interesting information on the question of whether the large majority in favour of the continuation of the political alliance with the Netherlands also indicates a desire to continue within the existing framework of the Charter. The results illustrate the ambivalence involved in the continuous strengthening of the Kingdom ties.

It became absolutely clear that the Antilleans and Arubans considered the political relationship between the Netherlands and the islands of the upmost importance (tables 1-4). For a large majority of the populations on all islands, the real choice is whether to continue the present situation of self-governance, or to intensify relations with the metropolis. Antillean and Aruban citizens welcome a strong Dutch involvement. In many respects they believe that a strengthening of the relationship would be positive, and even necessary. Not only does this apply to administrative and financial affairs, but also to subjects within the spheres of education and culture.

These results indicated a certain difference in viewpoint between the citizens and their administrators, with the latter placing a larger emphasis on autonomy. The citizens' viewpoint could be closely linked to the lack of belief in self-sufficiency and viability of their island societies - and possibly with their rather limited confidence in the domestic politicians and administrators. ${ }^{10}$ In this respect, the results of Ki sorto di Reino? could be interpreted as a strong argument for the Dutch policy of intensification of the relations and an increase in control exacted on the Caribbean administrations.

However, ambivalence caught the eye immediately: there are clear reservations about an actual intensification of Dutch involvement. Support for the extreme option, the assimilation of the Caribbean territories into the metropolis as overseas provinces, appeared very limited, although public support would increase if the current construction of the 'Antilles-of-fiveislands' were to fall apart. The physical realisation of an intensified policy evoked equally mixed reactions, judging by the opinions regarding the recent involvement of Dutch executives in various sectors of Antillean society (eg. law enforcement, trade and industry, administration, education). It is characteristic that the objections were strongest in those areas where, during the 1990s, Dutch involvement has been more intensive than usual particularly on the islands of St. Martin and Aruba. Apparently intensive involvement by the mother country does not necessarily lead to the desire for even further engagement.

A key in all of this appeared to be the deep-rooted feeling that the Netherlands demonstrates an insufficient understanding and respect for the local societies and cultures (tables 5-7). This grievance is shared by both 
Views and Expectations of Antilleans and Arubans regarding their Relationship with the Kingdom of the Netherlands, 1998

Source: Oostindie \& Verton 1998a: 51-3, 57-8; 1998b: 29-31, 34-5.

Table 1. Preferences regarding the relationship with the Netherlands (in \%)

\begin{tabular}{lrrrrrr} 
& & & & \multicolumn{3}{c}{ St.Eusta- } \\
Independence & 5.2 & 1.8 & 6.6 & 0.0 & 1.5 & 15.3 \\
Status Quo & 65.2 & 36.6 & 50.4 & 39.7 & 25.8 & 40.9 \\
Closer Ties & 26.8 & 59.9 & 40.9 & 58.2 & 72.2 & 34.5 \\
No Opinion/ & 2.8 & 1.6 & 2.1 & 2.1 & 0.5 & 9.3
\end{tabular}

Table 2. Opinion on province status (in \%)

$\begin{array}{lrrrrrr} & \text { Aruba } & \text { Bonaire } & \text { Curaçao } & \text { Saba } & \text { St.Eusta- } & \text { St.Martin } \\ \text { Positive } & 11.6 & 37.4 & 24.4 & 40.2 & 54.5 & 19.0 \\ \text { Negative } & 78.8 & 59.7 & 68.4 & 49.2 & 40.4 & 68.6 \\ \text { No Opinion/ } & 9.6 & 2.9 & 7.2 & 10.6 & 5.1 & 12.4 \\ \text { No Answer } & & & & & & \end{array}$

Table 3. Is the Netherlands too involved in running our country? (in \%)

\begin{tabular}{lrrrrrr} 
& & & & \multicolumn{3}{c}{ St.Eusta- } \\
Yes & Aruba & Bonaire & Curaçao & Saba & tius & St.Martin \\
No & 40.9 & 38.0 & 37.6 & 12.7 & 18.7 & 40.4 \\
No Opinion/ & 48.7 & 52.4 & 50.7 & 73.5 & 75.8 & 47.9 \\
No Answer & 10.3 & 9.7 & 11.7 & 13.8 & 5.6 & 11.7
\end{tabular}


Table 4. Overall opinion on Dutch involvement (in \%)

\begin{tabular}{|c|c|c|c|c|c|c|}
\hline & Aruba & Bonaire & Curaçao & $S a b a$ & $\begin{array}{r}\text { Eusta- } \\
\text { tius }\end{array}$ & St.Martin \\
\hline Positive & 23.8 & 42.9 & 35.9 & 36.5 & 51.0 & 10.6 \\
\hline Neutral & 67.2 & 48.8 & 55.4 & 50.8 & 44.9 & 75.6 \\
\hline Negative & 5.2 & 5.0 & 3.1 & 2.1 & 2.5 & 7.4 \\
\hline $\begin{array}{l}\text { No Opinion/ } \\
\text { No Answer }\end{array}$ & 3.8 & $3 \cdot 7$ & 5.5 & 10.6 & 1.5 & 6.3 \\
\hline
\end{tabular}

Table 5. Opinion on the level of Dutch respect (in \%)

\begin{tabular}{|c|c|c|c|c|c|c|c|}
\hline & \multirow[b]{2}{*}{ Aruba } & \multirow[b]{2}{*}{ Bonaire } & \multirow[b]{2}{*}{ Curaçao } & \multicolumn{2}{|c|}{ St.Eusta- } & \multirow[b]{2}{*}{ St.Martin } & \multirow{5}{*}{ 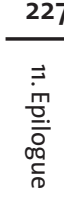 } \\
\hline & & & & Saba & tius & & \\
\hline Sufficient & 41.1 & $45 \cdot 3$ & 42.8 & 63.0 & 50.5 & 21.4 & \\
\hline Insufficient & 49.5 & 43.7 & 44.2 & 23.8 & 39.4 & 62.3 & \\
\hline No Opinion/ & 9.4 & 11.0 & 13.0 & 13.2 & 10.1 & 16.3 & \\
\hline
\end{tabular}

Table 6. Opinion on the level of Dutch acceptance of cultural difference (in \%)

\begin{tabular}{lrrrrrr} 
& & & \multicolumn{3}{c}{ St.Eusta- } \\
& Aruba & Bonaire & Curaçao & Saba & tius & St.Martin \\
Sufficient & 37.5 & 36.9 & 39.7 & 36.0 & 42.9 & 24.4 \\
Insufficient & 49.8 & 47.6 & 43.4 & 48.7 & 45.5 & 63.9 \\
No Opinion/ & 12.7 & 15.4 & 16.9 & 15.3 & 11.6 & 11.7 \\
No Answer & & & & & &
\end{tabular}

Table 7. Opinion on Dutch understanding of local culture (in \%)

\begin{tabular}{lrrrrrr} 
& & & \multicolumn{3}{c}{ St.Eusta- } \\
& Aruba & Bonaire & Curaçao & Saba & tius & St.Martin \\
Sufficient & 26.5 & 25.9 & 29.9 & 18.5 & 15.7 & 6.5 \\
Insufficient & 59.6 & 55.8 & 53.4 & 70.4 & 79.3 & 87.1 \\
No Opinion/ & 13.9 & 18.3 & 16.6 & 11.1 & 5.1 & 6.3 \\
No Answer & & & & & &
\end{tabular}


citizens and politicians and administrators. This unity of opinion is of crucial importance. The notion of 'cultural difference' tends to be used whether it is relevant or not, and sometimes also in order to steer clear of a more fundamental discussion on values and norms within the Kingdom. There is no reason whatsoever to state that the gap between the Dutch and the Caribbean cultures is unbridgeable. 'Cultural difference' is no insurmountable obstacle in transatlantic relations. However, a possibly stronger Dutch involvement combined with a local feeling of being insufficiently understood and respected, bears the seeds of conflict. One remembers the wise words of the famous Dutch orientalist Christiaan Snouck Hurgronje, criticising the Dutch self-congratulatory mood on their own - harsh - colonialism in the Dutch Indies: 'No matter how corrupt a Native Administration may be, it hardly ever occurs that its subjects are therefore prompted to long for our rule. ${ }^{11}$

There is also ambivalence on the Dutch side. The average Dutch citizen plays no role of importance, at least as long as Antillean immigration does not weigh too heavily on relations. In Dutch politics the Caribbean dossier is of little importance, and hardly ever disputed. It is typical that parliament has seldom hampered the ministers in charge, maybe with the exception of the years shortly after the Curaçaoan revolt of 1969. Even though Dutch administrators are faced with the same dilemmas as their Antillean and Aruban counterparts, they weigh considerably less heavily in The Hague. This has always been the case, which also helps to explain why the Charter and its workings seem to have acquired a certain 'eternal quality'. In the end, the 'burden' of the post-colonial relations has never weighed heavily enough to make The Hague opt for really radical - and possibly judicially contestable - policies. This dossier has never caused much commotion or difficulty within Dutch politics. Changes in direction are rarely challenged in the House of Commons, the small number of politicians concerned with this issue have little problem with minor experiments in a dossier which has no appreciable political weight.

Initially, the restriction of the Kingdom ties was felt by only a relatively small group of nationalists, particularly in Suriname. Gradually these ties were also experienced as restrictive in Dutch political circles. In this context Suriname gained its independence. Since that time the political elites on the islands have declared time and again that they are completely satisfied with the Charter. The Netherlands, however, was still seeing the Kingdom ties as restrictive, and was therefore initially striving for a severance and, after this was found to be impossible, for a thorough revision of the relations. This change of direction encountered much resistance from Antillean and Aruban administrators, as a result of which they also began to feel restricted. However, a departure from the Kingdom was never seriously considered.

At present, neither the Netherlands, the Antilles nor Aruba has em- 
barked on a policy to end mutual ties. For each country pragmatism dictates the chosen position. For the Netherlands this is above all the realisation that independence cannot be imposed - that is just the way it is. ${ }^{12} \mathrm{~A}$ more positive feeling of connection with the islands or a belief in the enhanced value that the transatlantic character gives the Kingdom, are at best of secondary importance. For the Antilles and Aruba, cultural ambivalence notwithstanding, the Kingdom forms an indispensable guarantee for the wellbeing of their inhabitants. Politicians and citizens have been of this understanding for decades, increasingly so with migration, aid and politics in this order -serving to cement the transatlantic bonds.

\section{The Future}

What of the future? Discomfort with the structure of the transatlantic Kingdom has grown considerably during the last decade. In the Netherlands Antilles centrifugal tendencies were apparently only shortly subdued in the mid-199os. The Hague, meanwhile, has grown increasingly weary of the present relations within the Kingdom, with their many unresolved problems. Since the last failed attempt in 1993, however, successive Dutch governments have refused to put on the agenda changes in either membership or content of the Charter, deeming the first undesirable, the second unattainable. ${ }^{13}$ Yet it seems unlikely that this policy will be perpetuated.

Centrifugal tendencies continue to be the thread running through the fabric of Antillean history. That in the end Aruba's long running battle for an autonomous status as a country within the Kingdom was rewarded, has created a precedent with other islands striving for the same status. This applies not only to the present 'eternal second one' St. Martin, but also to Curaçao itself. In the beginning of the 1990 os the Netherlands was willing to cooperate in dismantling the Antilles. This has not been pursued - partly as the islands felt that the clauses put forward by The Hague were unacceptable, and partly as a result of the intervention by the Antillean citizens, who at that time-against the wishes of their own leadership - chose en masse for the continuation of the current construction of the Antilles-of-five-islands.

Following this, the theme disappeared from the political agenda as the Antillean government under Miguel Pourier strove to develop initiatives for the necessary restructuring of the country. Little was accomplished though, and soon afterwards centrifugal tendencies were once again escalating. A referendum/plebiscite in 2000 demonstrated that St. Martiners now concurred with their politicians' goal - that of a separation from the Antilles. In 2002, the incoming Antillean government squarely pledged in its coalition agreement to be the last Antillean government ever. Of course it takes two to tango, and in this sense the Netherlands is now in a comfortable position, since according to the Charter a possible dismantling of the 
five-islands-structure will only be possible with Dutch approval. ${ }^{14}$

So the Netherlands is facing the same dilemma as it was at the lead up to Aruba's separate status. The outcome is as yet inconclusive. While until very recently the Dutch flatly refused to discuss a further fragmentation of the Antilles, this position seems to be changing slowly. ${ }^{15} \mathrm{~A}$ collapse of the Antillean structure may well be regrettable and will neither politically, judicially nor administratively easily lead to a favourable conclusion. Yet the past decade of muddling through on the part of island parties that in reality do not want to be cooperative, has weakened the administrative machinery of the islands to an unacceptable level. So it is not only respect for the wishes of its Caribbean partners, but also sheer pragmatics which will force the Netherlands to discuss the dismantling of the five-island nation in the near future.

While the islands have been pressing for a change in membership of the Charter, being weary of discussing changes in the Charter's contents, The Hague's views have been entirely contrary in nature. Although at the time the Charter was introduced as 'geen eeuwig edict' - a pact not intended for all eternity - no changes were implemented during the near half-century of its existence, apart from its membership, with Suriname leaving and Aruba acquiring a status aparte. The reason for the virtually identical character of today's Charter initially lay in the contentment of the parties involved. Next came discontent, the secession of Suriname, the Antillean refusal to follow this path and the Dutch attempt to reformulate the Charter. The failure to achieve this can be attributed exclusively to the rigid nature of this document, which can only be amended with the approval of all parties concerned. This makes the 'Antillean dossier' so inflexible. Since the Caribbean partners tend to expect a curbing of their autonomy as a result of any amendment of the Charter, they have always been reticent to entertain the proposals put forward by a long series of Dutch administrators.

Yet it is a legitimate suggestion that the Charter, with its strong emphasis on domestic autonomy, is long out of date as a basis for the Kingdom. Apparently the document was made dynamic enough to be able to survive the changes that have taken place during almost half a century, both within and outside the Kingdom. This is indeed an achievement by the legislators of the time. However, since 1954 the world has decisively changed. Increasing international 'interweaving' in all fields has become the key word. This interweaving is strikingly clear within the European Union, a voluntary alliance to which the Netherlands is ceding much of its original sovereignty. As a result of this, at present the Netherlands is less autonomous within the European Union (which has already taken over more than one half of all legislation relevant to the Netherlands) than the Antilles and Aruba are within the Kingdom. ${ }^{16}$ Meanwhile globalisation has increased job and capital markets enormously, as well as migration movements and the effects of threatening factors such as international crime. Against this background the tra- 
ditional notions of sovereignty and autonomy are being strongly eroded.

In this context the need of the Antilles and Aruba for a life line with the Netherlands has in no sense been reduced, but over time tensions between the tasks relating to the Kingdom and the local autonomy have increased. Against this background it is implausible that in the long term an unamended Charter will remain the highest legal regulation of the Kingdom. The question of how to make the transatlantic relations function successfully for the wellbeing of all citizens within this Kingdom - whereby the Caribbean populations will increasingly live on both sides of the Atlanticcontinues to be an issue. A disputed one at that. There should be no illusions regarding a total consensus or an end to ambivalence, which after all is a given in this situation of differences in power and culture.

The present rigidity in relations, and specifically within the Charter, can only be broken down satisfactorily once all parties perceive a shared interest. This supposes amongst other things a stronger sense of mutual trust a condition which is still insufficiently met. In spite of relatively cordial relations between the protagonists on both sides, deep differences remain. Thus on the Dutch side the feeling persists that Antillean and Aruban elites are not really prepared to break away from a protectionist system which is detrimental to local development but at the same time cements their own privileged positions. Furthermore, one still senses a deep distrust in The Hague of a Caribbean political system presumably characterised by clientelism, as well as doubts as to whether even its most respected leaders are able to accomplish a breakthrough. On the other side, there is deep frustration over a perceived lack of positive Dutch engagement and a presumed overkill of often inconsistent and sometimes hypocritical metropolitan directives bordering on a patronising and distrustful attitude. ${ }^{17}$

An alternative for a jointly charted change in direction could come about with a further toughening of the Dutch position. However, a collision course would be of no benefit to anyone. Not to the Antilles and Aruba, because an enforced amendment through harsh measures, or a drastic revision of the workings of the Charter, would without doubt make their cherished autonomy a thing of the past. But the Netherlands should also realise that a possible abrupt, imposed re-balance of power would be extremely problematic. In this respect, the very critical local reactions to the intervention of the Dutch in the administrations of St. Martin and Aruba are the writing on the wall.

In the 1980s, Minister for Antillean and Aruban Affairs Jan de Koning pursued a policy officially aimed at a quick realisation of independence for the remaining Caribbean partners. In private however, in a memorable anecdote, he confided to Queen Beatrix that he expected 'that we will enter the next century with the Charter'. This became a reality, and indeed these ties within the Kingdom will continue to exist for many years. It is less likely that the style, workings and understanding of the transatlantic King- 
dom will remain unaltered. One would expect the administrators on both sides of the Atlantic to view this as a sign of the times. In no way does this need to be contrary to a strong and positive mutual involvement. As stated above, particularly The Hague has been unwilling to open the Pandora's box of a debate on a revision of the Charter. Yet the very latest news clippings and the May 2003 policy statement of the second cabinet Balkenende suggest that changes may be afoot. ${ }^{18}$

In a wider Caribbean context, the demise of the classical model of decolonisation has left the region ever more divided. Due to a shared history of Amerindian extinction, European colonisation, African slavery and Asian indentured workers fulfilling the labour requirements of the plantation economy, the Caribbean developed into one cultural area indeed. Yet from the very beginning the four European colonisers left their own legacies, compounded by the late American arrival. Thus we have a region divided by differences in natural and economic resources and scale, population figures and densities, ethnic backgrounds, and colonial legacies as in languages, culture and political traditions. The 37 million Caribbean people live in 28 different political entities of which no less than 22 are states or territories with a population of less than one million. Half of these are sovereign, the other half are not. ${ }^{19}$ Today we witness an apparently growing disparity between the sovereign and the non-sovereign parts of the Caribbean.

Now that King Sugar and the Cold War are firmly in the past, the geopolitical weight of the Caribbean has greatly diminished. The three issues figuring most prominently on the international - particularly American and Western European - agenda for the region are the fight against narcotrafficking with its related criminal activities, migration within and particularly out of the region, and sustainable economic development according to the prevalent new liberal orthodoxy. ${ }^{20}$ There is little ideological divide remaining. With the exception of Cuba, a law unto itself, there are no serious, and certainly no insurmountable political divides separating the Caribbean from the historical metropolitan powers, nor for that matter from the dominating new ones. Serious divergences exist with regard to material wealth and the possibility of realising individual potential - the very rationale behind the huge migratory waves which have come to characterise the contemporary Caribbean and actually in the process have drawn the former colonisers and colonised closer together. These divergences are in turn linked to contrasting constitutional arrangements, basically the divide between sovereign and non-sovereign nations. It is these differences which serve to perpetuate, if not widen, the divides within today's Caribbean.

There is no indication that any of the non-sovereign Caribbean territories will relinquish the tangible rewards of their present post-colonial status for the sake of a redemptive nationalist ideology - not even in Puerto Rico which is often referred to as a colony by its own citizens. ${ }^{21}$ Differences 
in standards of living between these islands and their metropoles seem stable. Yet of more significance within the region, the paths followed by the non-sovereign and the sovereign Caribbean as a whole appear ever divergent. This does not bode well for any project attempting pan-Caribbean integration. Thus the establishment in 1994 of an Association of Caribbean States (ACS), which includes not only the Caribbean archipelago and the Guyana's but also extents to the Central American republics, Mexico, Colombia and Venezuela, reflects a genuine will to explore common interests, and is not in the least bit a reaction to the American dominance in the region. Yet in view of the continuing cultural divergences and variations, particularly in scale and economic interests, one cannot assume that the ACs will spark genuine integration. ${ }^{22}$ One may expect some further development towards subregional integration though. The participation of Suriname and, still more tentatively, Haiti and the Dominican Republic, and at one stage perhaps even of Cuba in the originally exclusively British West Indian CARICOM, is a case in point.

Within the non-sovereign Caribbean, a stronger alliance between the four blocs and their metropolitan powers seems logical when it comes to issues such as the fight against drug trafficking and related activities. Intensive cooperation seems particularly logical between the three 'European' Caribbean subgroups. So far, the European Union has been mainly a continental affair. For better or for worse, the Union will undoubtedly continue to extend its endeavours and bureaucracies to its members' post-colonial remnants in the Caribbean. 'Be prepared' is sound advice for its leaders in places such as Pointe-a-Pitre, St. John's, or Oranjestad. So far, however, few in power seem to heed such advice, and among the electorate even fewer. This negligence may well prove costly once they find themselves at the negotiating tables of Brussels - should they ever get there. Furthermore, they, along with their metropolitan patrons and Brussels, will have to start thinking more seriously about ways of coping with the ever increasing disparity between these privileged non-sovereign remnants of empire and the rest of the Caribbean, which definitely faces harsher challenges. 


\section{Notes}

\section{Acknowledgements}

1 Adhin was a prominent Surinamese scholar and politician; Croes is former Plenipotentiary Minister for Aruba in The Hague (1994-2002); de Haseth held the same position for the Antilles (1994-1998 and again 2000-2003); Hirsch Ballin is former Minister for Antillean and Aruban Affairs (1989-1994) and member of the Council of State of the Netherlands; Hoetink is a prominent scholar and served on many committees regarding Caribbean affairs.

2342 Cramwinckel is senior civil servant at the Ministry of the Interior and Kingdom Relations; Van Dijck is an economist at the Centre for Documentation and Research on Latin America at the University of Amsterdam; Price is an anthropologist dividing his time between Martinique and the College of William and Mary in the United States; de Vries served as State Secretary of the Ministry of the Interior and Kingdom Relations (1994-1998) with Antillean and Aruban affairs as his major assignment.

\section{Introduction}

1 General introductions to Caribbean history such as Parry, Sherlock \& Maingot 1987 or Knight 1990 tend to virtually neglect the Dutch Caribbean, the same is true when it comes to decolonisation. With the recent exception of Ramos \& Rivera (2001b), studies of decolonisation tend to focus either on one of the more populated Caribbean countries or on the British or French West Indies as an entity. Mention of the most important studies on post-war decolonisation is made in Chapters 1-3.

2 Oostindie \& Klinkers 2001. For the present book we have translated all quotations from Dutch oral and written sources ourselves, always attempting as accurate a translation as possible. The few English-language studies on Dutch Caribbean decolonisation, mainly articles, include Gastmann 1964, Dew 1978, Sedoc-Dahlberg 1990, Hoefte \& Oostindie 1991, Oostindie 1992, Ledgister 1998:13578, Oostindie \& Verton 1998a, Giacalone 2001, Hoefte 2001, Lampe 2001, and Meel \& Hoefte 2001. See also Oostindie 2004 (forthcoming).

3 Oostindie \& Verton 1998:37, 197-9. In Suriname, the February 2002 royal wedding ceremony of crown prince Willem-Alexander and his Argentine fiancée Máxima were broadcast integrally and live on television - over a quarter of a century after independence.

4 Centre-left coalitions in 1945-1958, 1965-1966, 1973-1977, 1981-1982, and 19891994; centre-right ones in 1958-1965, 1966-1973, 1977-1981, and 1982-1989. 
5 Two successive 'purple' coalitions under Prime Minister Wim Kok ruled from 1994 to 2002. Since then, once again, the Netherlands has been ruled by the centreright.

6 Ironically, the one exception being den Uyl's own position in the ill-fated 19811982 centre-left cabinet of Dries van Agt.

\section{The Comparative Context: Fragmentation of the British West Indies and the Remnants of Empire}

1 Dates of colonisation: Anguilla 1650; Antigua 1624; Bahamas 1627; Barbados 1627; Barbuda 1667; Belize (ca. 1640); Bermuda 1612; British Virgin Islands 1672; British Guiana 1814 (in 1814, at the end of the Napoleonic wars, the British bought Demerara, Essequibo and Berbice from the Dutch, which in 1831 were united as British Guiana); Cayman Islands 1670; Dominica 1783; Grenada 1814; Jamaica 1655; Montserrat 1632; St. Kitts-Nevis 1783; St. Lucia 1814; St. Vincent 1783; Tobago 1803; Turks and Caicos Islands 1678; Trinidad 1797.

2 In the present political constellation twelve of the sixteen independent countries in the Caribbean are Anglophone. The non-English-speaking states being HaitianCreole-speaking Haiti (1804), the Spanish-speaking Dominican Republic (1844) and Cuba (1901), and polyglot but officially Dutch-speaking Suriname (1975).

3 In an effort to combat this tendency, various attempts were made at uniting as many territories as possible. For example, the Cayman Islands were a dependency of Jamaica between 1670 and 1958; the Turks and Caicos Islands became a dependency of Jamaica in 1874 (the islands were governed as part of the Bahamas colony between 1766 and 1848, and again between 1962 and 1973); the Windward Islands were placed under the administration of one Governor in the 1830s; and St. Kitts, Nevis, Anguilla and the British Virgin Islands were governed as one administrative unit between 1816-1871, until the Leeward Islands Federation was formed.

4 There had always been talk of a Caribbean federation of some sort among British politicians. The history of placing the islands under one administration even goes back to 1705, with the short-lived establishment of the 'Federation of the Leewards'. Members of the Leeward Islands Federation: Anguilla, Antigua, Barbuda, British Virgin Islands, Montserrat, and St. Kitts-Nevis. In 1871-1940 Dominica also formed part of this constellation. Members of the Windward Islands Federation: Grenada, St. Lucia and St. Vincent, Dominica (temporarily) and Trinidad and Tobago. Also after this federal intermezzo the Windward islands (Barbados, Tobago, Grenada, St. Vincent and St. Lucia) remained under the administrative authority of one Governor.

5 In the words of Minister of Colonial Affairs Leopold S. Amery: 'The whole system, with its haphazard complexity and lack of coordination on any structural basis, would be fancy, not to be tolerated for a moment by our more logical neighbours across the Channel. For all that, I believe that our system, or lack of system, has certain advantages.' Quoted in Von Albertini 1982:88.

6 Von Albertini 1982:102.

7 The British Commonwealth of Nations became offical in 1921: a body politic of dominions voluntarily bound together, all enjoying equal rights and full autonomy. 
The colonies also formed part of this Commonwealth, albeit in a situation of full dependence on the United Kingdom.

8 In 1940 the Colonial Development and Welfare fund was established, which on a yearly basis allowed for five million pounds to be spent on the colonies during the next ten years. 'The increase of the sum was considerable, if one recalls the resistance in 1929, even though it still seems minimal with respect to actual needs and by comparison with the means provided after 1945.' Von Albertini 1982:113.

In 1945 the economic reorientation begun during the interbellum period was given new input through the Colonial Development and Welfare Act of the same year, making available 120 million pounds to all colonies during a ten year period. It would take until 1951 before democratisation in the British Caribbean received an important impulse, with universal suffrage now being extended to almost all islands (in the following order): Jamaica (1944); Trinidad and Tobago (1946); Barbados (1950); Anguilla, Antigua, Barbuda, British Virgin Islands, Dominica, Grenada, Montserrat, St. Kitts-Nevis, St. Lucia and St. Vincent (1951); British Guiana (1952); British Honduras (1954); the Bahamas (1961); and finally Bermuda (1963). The Turks and Caicos Islands and the Cayman Islands, all asssociated with Jamaica, also received universal suffrage in 1944 .

9 In 1942 the Minister of Colonial Affairs Oliver Stanley stated: 'We are pledged to guide the colonial peoples along the road to self-government within the framework of the British Empire.' Austin 1980:12. Likewise, the words of the Labour Minister of Colonial Affairs Arthur Creech Jones (1948), 'to guide the colonial territories to responsible self-government within the Commonwealth in conditions that ensure to the people both a fair standard of living and freedom from oppression from any quarter'. Quoted in Ansprenger 1989:162.

10 At the end of World War II the British Empire still stretched worldwide. After the independence of British India (India and Pakistan, 1947) followed the gradual liquidation of the remainder of the British imperium. In 1946 Transjordania (present-day Jordan) became independent, Palestina in 1948. In Asia, Burma achieved independence outside of the Commonwealth in 1948; in 1957 the federation of Malaya achieved independence, and in 1959 Singapore also became independent (in 1963 Malaysia was born: Malaya, Sarawak and North Borneo). The largest part of British Africa was decolonised in the period between the independence of Goldcoast in 1957 and of Nyasaland (Malawi) and North Rhodesia (Zambia) in 1964. The most important British 'decolonisation trauma' had, however, already taken place in the late eighteenth century, with the successful war for independence by the United States (1776).

11 Knight 1990:302.

12 See Sutton (1991:61): 'The Commonwealth Caribbean, as a scattering of separate states, was born out of the failure of the West Indies Federation in 1962.'

13 Drower 1992:24.

14 In Guyana a dominating party came to the fore during the 1950s, led by the marxist Dr Cheddi Jagan. The government that was formed in 1953 under the leadership of this party was thrown over by the British government (the United Kingdom suspended the local Constitution). These political developments paved the way for the severe racial conflicts of the 1960 .

15 In 1966 the Colonial Office was linked to the Commonwealth Relations Office, which coordinated relations with the dominions. This merger was renamed the Commonwealth Office and was housed in Whitehall, London. 
16 A possible striving for full independence by these territories was in fact discouraged by the condition that the respective state would need to conduct a referendum, which would need to yield more than two thirds of the votes in favour of independence. Yet the Colonial Office could unilaterally terminate all ties, provided it had given six months notice. Only in case of union or federation with another Commonwealth country in the Caribbean no referendum was required.

17 Drower 1992:135. Associated Statehood had many parallels to the status of Suriname and the Netherlands Antilles under the 1954 Charter. Not only formally, but also in a material sense, since both models harbour the possibility of effectuating sovereignty. Nonetheless, the associated status provided the United Kingdom with more possibilities for intervention, while these states lacked any influence in British politics. Under the Charter the Caribbean countries of the Kingdom of the Netherlands can, through their Plenipotentiary Ministers or any special delegates, make their voices heard. To compare: the French départements d'outre-mer have their own representatives in the French Assemblée. Also see Crassweller (1972:240): 'In terms of legislative freedom this arrangement [Associated Statehood] gives the island states more authority than Puerto Rico has, but the financial advantages are less substantial.'

18 In September 1968 George Thomson, the then Minister of the Foreign and Commonwealth Office, reiterated the fundamental principle of self-determination as the basis for British policies relating to the Dependent Territories: 'There still remain a number of British Dependent Territories around the globe. We do not know what their ultimate constitutional future will be... A few of those territories may wish to proceed to independence. Others may not. It is always difficult to forecast. But, whatever the future holds, we in Britain will always adhere closely to the cardinal principle to which we have adhered in the past - that the wishes of the people concerned must be the main guide to action - it is not and never has been our desire or intention either to delay independence for those dependencies who want it or to force it upon those who do not.' Quoted in Drower 1992:xiv.

At the end of the 196os Britain's six Caribbean Dependent Territories were: the Bahamas, Bermuda, British Virgin Islands, Cayman Islands, Montserrat, Turks and Caicos Islands.

19 Former official of the Foreign and Commonwealth Office, quoted in Drower 1992: $27-8$.

20 The parallels with the reaction within Dutch politics after the military intervention in the Curaçaoan revolt of May 1969 are evident. Even though the backgrounds were markedly different, around the same period of time both the United Kingdom and the Netherlands found themselves vulnerably exposed in the eyes of the world as colonial powers. Reality had shown that they were obliged to intervene in long running local conflicts over which they had not been able to exercise any real influence. In both countries the subsequent reaction was to rid themselves as quickly as possible of their colonial remnants.

21 In the summer of 1970 an official study started into future constitutional possibilities for the dependent territories. It was investigated whether there were any 'final obstructions' for the remaining territories to become independent, or that these were maybe of a temporary nature. The study would not be finished. 'From thereon the only choice available to most of Britain's territories was between continuing dependence or outright independence'(Drower 1992:27).

In January 1973 another study was undertaken (Programme Analysis Review) 
which amounted to a cost-benefit analysis, in an attempt to rationalise the decision making process. Emphasis was increasingly put on political decolonisation: 'It was increasingly becoming evident that small territories could survive as independent entities. As a consequence of that, the government was unwilling to contemplate offering all but the very smallest of territories any constitutional option other than independence' (Drower 1992:28-9). An official of the Foreign and Commonwealth Office characterised the atmosphere within the Ministry around 1975 as follows: 'One or two of my colleagues did have a rather simple view that all these places beyond the seas were rather a nuisance, and the sooner you could get shot of them the better. I think this was very true of Ted Rowlands [Foreign and Commonwealth Minister]. That was his attitude. He thought that was what he was there to do and the quicker we could get rid of these places the better' (quoted in Drower 1992:29).

22 In 1967 Anguilla and St. Kitts-Nevis together formed an Associated State. After the passing of the Anguilla Act in 1971 the island was administered by a British Commissioner. After its secession from St. Kitts-Nevis in 1980, Anguilla took a constitutional step backwards, to become a British Dependent Territory. 'In Anguilla, a quarter of a century after its separation from St Kitts-Nevis in order to remain a British colony, there is a widespread perception that this decision finalised Anguillian political status.' Economic motives were at the basis of this anti-independence feeling in Anguilla. See Connell 1994:91-2.

23 Thus far, only in Bermuda has a referendum been held on the political status of the island. The referendum of 1995 showed a considerable percentage of voters opting for independence $(25,6 \%)$, but a clear majority still chose to retain the status of Dependent Territory (73,6\%); attendance was low (59\%). See Connell 2001:125-9. 24 'Aspiring West Indian politicians, for the most part, both acquiesced in and helped fashion the parameters, with the consequence that when independence eventually came it was orderly, calculated and decidedly constitutionalist. At independence every Commonwealth Caribbean state therefore chose to express its personality through the Westminster-Whitehall system, suitably modified as might be expected to local context, but not changed in essence by that fact' (Sutton 1991:52). Only in later years would the rule of the Crown be replaced by a Republican form of government in some territories. Guyana and Grenada have been the only former British Caribbean colonies where parliamentary democracy was disrupted for a considerable period of time.

25 The United Kingdom had also had trouble with the status of Associated Statehood in the United Nations, which had denounced the lack of democratic choice at its inception.

26 Payne 1991:19.

27 The 1984 Memorandum of the Foreign and Commonwealth Office on the problems of small states affirmed: 'The last 20 years have witnessed the emergence of a large number of small independent states which are incapable of providing for their own economic or political security'(Drower 1992:xii). See Thorndike 1991:277 for the U-turn in British policies after 1983. 'Pressures from a variety of sources - not least the one million plus people of Caribbean ancestry in Britain - ensured that thereafter the English-speaking Caribbean in particular would occupy an important place in Britain's agenda of international politics.'

It is interesting to note that this British policy review preceded the one implemented by the Netherlands: not until March 1990 did Minister Ernst Hirsch Ballin 
put an end to the striving by the Dutch to make the Antilles independent, with his 'Sketch for a Commonwealth Constitution for the Kingdom of the Netherlands'. Attached to this were clear conditions with respect to the quality of law and order and good governance.

28 Quoted in Aldrich \& Connell 1998:30.

29 Conference report. The economic development of the Caribbean overseas countries and territories: the role of their European partners, The Hague, 20-21 June 2001. John Zevenbergen, p. 24 ('Korte situatieschets: Groot-Brittannië').

30 In May 1949 the British government had rejected the term 'overseas territories' as being 'cumbrous and colourless' (Drower 1992:xvii). Instead it had continued to use the word 'colony' until 1956, when it decided to tactfully rename the surviving colonies 'Dependent Territories'.

The British Overseas Territories (отs) are scattered throughout the world, with today's greatest concentration in the Caribbean. Other dependencies are in the Pacific, the Indian Ocean and the Atlantic Ocean: British Antarctic Territory, British Indian Ocean Territory, Gibraltar, Pitcairn Islands, St. Helena, Ascension, Tristan da Cunha, Falkland Islands, South Georgia \& South Sandwich Islands, as well as two British Crown Dependencies: Channel Islands and the Isle of Man. Among the former British West Indies, the Caribbean oтs are the smallest islands with few inhabitants. Whereas the population of Jamaica numbers more than two million inhabitants and Trinidad and Tobago 1.2 million, the Caribbean OTs have a total population figure of around 155,000.

31 Partnership for Progress 1999:13.

32 May 2002 saw legislation coming into effect, enabling the inhabitants of the отs to enter the United Kingdom through the same channels as British citizens and other Eu nationals (who at present include the inhabitants of the Dutch and French territories). Large-scale immigration from the Caribbean to the United Kingdom is not expected: with the territories' strong orientation towards the United States they are more likely to go there. See Chapter 9 for an analysis of migration policies of the four metropoles.

33 Historically, politically and socio-economically the islands have a tendency to diverge. Against this background the United Kingdom has traditionally conferred different levels of autonomy to the territories. This varied approach by the British is distinctly different from the one pursued by the Dutch, which was always based on thinking in terms of uniformity: despite differences in culture, political aspiration and economic development, the Dutch tried in Suriname and the Antilles to create parallel structures and provisions. Nonetheless the United Kingdom has been unable to avoid the 'separate status' issue of Anguilla, a problem also common to the Dutch in their dealings with Aruba.

34 As part of the Treaty of Rome, Britain's Dependent Territories are associated with the European Union, which offers them favourable market access and aid allocations. See Chapter 8 for a comparative analysis regarding the aid policies of the four metropoles. The oTs receive considerably less funding from their metropolis than do the Dutch, French and American territories.

35 In the new millennium seventeen territories - mainly in the Caribbean and Pacific region - still figure on the United Nations list of 'Non-Self-Governing Territories'. Two million people live in these territories. The current administering powers are France (New Caledonia); New Zealand (Tokelau); the United Kingdom (Anguilla, Bermuda, British Virgin Islands, Cayman Islands, Falkland Islands, 
Montserrat, St. Helena, Turks and Caicos Islands, Gibraltar, Pitcairn Islands); and the United States (U.s. Virgin Islands, American Samoa, Guam). These powers must promote political and social development in the territories, and report annually to the United Nations.

36 For further figures and discussion, see Chapter 8.

37 Connell 2001.

\section{The Comparative Context: \\ The French départements d'outre-mer, Grandeur and Civilisation at a Price}

1 French diplomat Pierre de Margerie, 1918, quoted in Ansprenger 1989:31. The French have often justified their approach by denouncing the British system as undemocratic. Indeed, within the Commonwealth Caribbean referenda have never been conducted preceding independence; this the French considered a fundamental breach of democracy. (The 1961 referendum in Jamaica resulted in the island's independence, but the subject matter had regarded Jamaica's membership of the West Indian Federation.)

2 Compare Hirsch Ballin 2001:25. 'Strictly speaking, they [the DOM] don't have relations with France, because they are part of France.'

3 See Aldrich \& Connell (1998:25): 'Départementalisation represented the full entry of the Dом into French life-a concession no other colonial power in the 1940s was willing to consider.' The French state comprises 100 departments, 96 of which are situated on the mainland, 4 overseas (the DOM).

4 Representation for the Caribbean Dом in the metropolis is currently effected through four députés and two sénateurs for Martinique, alongside four députés and two sénateurs for Guadeloupe, and for the lesser populated Guyane two députés and one sénateur.

5 In the seventeenth century the heart of the French colonial empire lay in the Northern Americas and in the Caribbean. During the course of the eighteenth century France lost its American possessions to Britain, but extended its empire to large parts of Africa and Asia. At the end of the nineteenth century the whole of Indochina (Cochin-China, Annam, Tonkin, Laos and Cambodia) was under French control, as well as large parts of Africa, Antarctica and several islands in the Indian and Pacific Ocean. In addition, France controlled many trade routes. At the time only the British empire stretched further.

6 Marie Galante, Les Saintes, Saint-Barthélemy and the French part of St. Martin are administered as dependencies of Guadeloupe.

7 France was the first European nation to accept, in 1795, coloured colonial representatives into its national parliament. This system brought these delegates closer to the centre of power than was possible with Crown Colony government. However, internally the British West Indians had a larger say than their French counterparts, and France's vieilles colonies lacked basic constitutional laws found elsewhere in the Caribbean.

8 Von Albertini (1982:273): 'In spite of high-sounding phrases and a great deal of propaganda, internal political considerations, the lack in understanding of colonial affairs and the increasing needs of the metropolis won the day.' 
9 See Ansprenger (1989:104-5): 'In general there emerges an impression of halfheartedness in colonial matters which was scarcely if at all affected by changes in political majorities in Paris. The colonies were a subject of equal indifference to all sections of public opinion and for all French political parties and their leaders. [...] At all events the shock of 1940, the destruction of the real Maginot line, was needed to jolt France out of its colonial lethargy.'

10 In the category of états associés were the separate states with internal autonomy (among which old protectorates like Vietnam, Cambodia, Laos, Tunesia and Morocco), while the territories that were being administered by the French on behalf of the United Nations (like Togo and Cameroon) were counted among the territoires associés. The départements d'outre-mer (DOM) were formed, as stated before, by the vieilles colonies in the Caribbean and the island of Réunion in the Indian Ocean. Those territories that had maintained their former status (particularly the French colonies in Africa) became territoires d'outre-mer (том).

Both the ром and the том were newly created constitutional categories and appeared for the first time in the Constitution of the Fourth Republic (October 1946). The том - at present Nouvelle-Calédonie, Polynésie Française, Wallis-etFutuna and Terres Australes et Antarctiques Françaises - have more administrative autonomy than the Dom; although they are not classified as departments, they are still integral parts of the Republic. However, French legislation only applies in the том if this is explicitly stated.

Finally, France's two collectivités territoriales are Mayotte and St. Pierre-etMiquelon. These territories form a combination of Dом- and том-traits. They are integral parts of the Republic.

11 The Dutch would also successfully avoid any reference to the principle of selfdetermination in the 1954 Charter for the Kingdom of the Netherlands. Apart from its membership, the Charter remains virtually unaltered and is still the effective political framework for Dutch relations within the transatlantic Kingdom.

12 Two Constitutional Assemblies, including (indigenous) representatives from the colonies for the first time in history, had preceded the Union, as well as two plebiscites. Aimé Césaire, the later mayor of Fort-de-France (Martinique), had played a primary role in the proposal for departmentalisation. Césaire, who on behalf of Martinique and the Communist Party had been representative to the French Assembly for some years, was the leader of an exclusively left-wing Caribbean delegation. The socialists and communists had emerged strongly from the war, and were the advocates of this assimilation concept (supported in this by the democratic Left and progressive Centre); they were united in this cause with their metropolitan partisans.

13 Article 72, which concerns France's collectivités territoriales, makes no particular mention of the Dом: 'The territories of the Republic are the councils, the departments and the overseas territories.' The Dом are thus not in a category of their own.

14 Aldrich \& Connell (1998:76): 'This fine legal point recognised that départements located thousands of kilometres from France and exhibiting a different economic, demographic and cultural structure could not be treated in exactly the same way as metropolitan départements.'

15 Quotes from Debrot 1953:161 and Burton 1995:2, respectively. Like Burton, Hintjens (1992) presents the ties between the islands and the French state as resembling family relations. This analogy suggests why political grievances tend to be 
voiced within the context of the French State rather than taking the shape of a direct attack on the French presence in the Caribbean. The 'family concept' also sheds some light on the isolation of the French Antilles vis-à-vis the rest of the region.

16 There was an amount of political contingency at play here. Directly following the war, right-wing parties had become discredited due to their political bonds with Vichy. The first post-war Constitutional Assembly was dominated by leftwing political factions, among which a strong Communist Party. It was essentially on the left of the political spectrum that the concept of assimilation had been advocated. Only a year later the communists were ousted from government. At that stage, it would have been considerably more difficult, if not impossible, to introduce the legislation for départementalisation.

17 Aldrich \& Connell 1992:73-4. A vital difference with British attempts at federalisation was thus that the initiative for departmentalisation came from the inhabitants of the French Caribbean themselves: apparently, through their long-standing bond with France, the vieilles colonies were already that French.

18 Burton (1995:3): 'Departmentalization was opposed in 1946 only by the béké [planter class] minority and by a handful of prescient spirits who feared for the survival of the traditional economies and who regretted the loss of the limited, but nevertheless real, influence that local people could bring to bear on colonial governors and officials under the old régime.' See also Blérald (1988:79-80.

19 In Vietnam Ho Chi Minh had proclaimed independence in 1945. See Von Albertini (1982:497): 'Only after France, on 6 March 1946, had accepted Ho Chi Minh's republic as part of the federation of Indochina did the Dutch accept the Indonesian Republic.' As with the Dutch in Indonesia, French intentions with Indochina failed. France's attitude towards the Caribbean, however, was not influenced by events in Asia as were Dutch decolonisation policies in the Antilles and Suriname.

20 In Africa most territories gained sovereignty during the 1950 and early 1960 s (Tunesia and Morocco in 1956, the Sub-Sahara region and Madagascar in 1960, and Algeria in 1962).

21 Only Djibouti, the Comoros and Vanuatu, alongside the ром-том, remained. See Von Albertini (1982:524): 'France [...] started from the concept of Greater France and thought it could satisfy demands for emancipation with cultural assimilation, administrative coordination and the grant of citizenship and representation in the Paris parliament. The integration of the vieilles colonies served as the model. French hopes of creating an institutionalized whole that would cause the colonial peoples to renounce their claims to national emancipation remained alive until the final phase of decolonization.'

22 Compare Aldrich \& Connell (1992:77): 'But the idea that legislation passed by parliament and promulgated by the president was applicable immediately and in its totality to the ром unless otherwise indicated, was retained. Once again, the extent of this adaptation remained undefined.'

23 See Aldrich \& Connell (1992:78): 'But exactly what this indivisibility means has also provoked debate among legal scholars.' Naipaul (1982:193): 'The myth of nonseparation is carried to the extent that routes nationales, which presumably lead to Paris, wind through Martiniquan countryside.' And p. 196: 'That Martinique is France, and more than in appearance, that France has here succeeded, as she has perhaps nowhere else, in her “mission civilisatrice”, there can be no doubt.' See, however, the sophisticated analyses of Price 1998. See also Chapter 10. 
24 See Chapter 8 for figures on aid to the Dom. Compare Daniel 2001:62: 'the most elementary statistics reveal that departmentalisation has been, from its inception to the present day, a means for political elites tot attain economic resources from the mainland in order to reach the level of development of the former'. See also Constant 2001:91: 'the issue of political status has been the main political resource at the disposal of the periphery in bargaining with the centre'. De Volkskrant, 3-71999. Since the 1982 law on departmentalisation only a few small import substitution industries have been established in the French Caribbean. Guyane is a case apart: its space travel industry provides more than fifty per cent of the gross national product (Kourou is the base of the European Ariane space programme). 25 www.insee.fr/fr/insee-regions/guadeloupe (consulted 4-4-2003). Aldrich \& Connell 1998:23. Compare Réno (2001:10): 'The most undeniable success of the Assimilation Act is the social equality with metropolitan France. A comparison with the English-speaking Caribbean is remarkable in this respect.' And Hintjens (2001:36): 'In the 1990s, efforts to re-establish a shared identity and sense of allegiance among the population to the French State resulted in agreeing to demands for complete equality in social policies.'

26 Réno 2001:11. L'Express, 29-11-2001. Le Monde Diplomatique, January 2003, p. 6. Project de loi de finances pour 2003, adopté par l'Assemblée nationale-Tome vII : Département d'outre-mer (www.senat.fr/rap, consulted 4-4-2003).

27 Unck 2001:18. With the coming into office of the Jospin administration, the Ministère d'Outre-Mer, established in 1962, was transformed into a Secrétariat d'État à l'Outre-Mer within the Ministry of Interior Affairs (June 1997). The Secrétariat d'État houses 174 civil servants in Paris (who also work for the том). Divided over several other ministries in Paris, another 100 civil servants work for the ром-том. Over 87,000 civil servants work within the Dом-том.

28 Aldrich 1996:281.

29 See Hintjens 1995:26-8.

30 Even though the communist elites did not strive for a secession from France, they were seen as separatists, especially in the eyes of the metropolis. In 1956 Césaire broke with the Communist Party to form his own Progressive Party of Martinique with the goal of 'the furtherance of the Martiniquan identity through the transformation of Martinique into a region within the context of a federal French Union' (translated from quotation in Blérald 1988:127).

31 See Hintjens, Loughlin \& Olivesi 1995:115. Compare Hintjens (2001:28): 'Once equal rights were obtained, and social parity was more or less achieved, challenges to assimilationism started to arise.'

32 See Aldrich \& Connell 1992:78. Some commentators found that départementalisation adaptée had as its primary objective the enhancement of the powers of the overseas Prefects, and not so much decentralisation of administrative powers. Hintjens 1995:30.

33 See Knight 1993:29-30.

34 See Aldrich \& Connell 1998:122-3; Hintjens, Loughlin \& Olivesi 1995:116. Compare Réno (2001:10): 'the demand for decolonisation is grounded less on a desire to achieve sovereignty than on the rational concern to maximise the advantages of dependency.'

35 Aldrich \& Connell (1992:79-80): 'Supporters of the Mitterand government judged this a satisfactory move towards a degree of autonomy, and many opponents of décentralisation were ultimately won over.' 
36 The Dom have two assemblies with local administrative power: the departmental assembly is generally responsible for the day-to-day administration, the allocation of finances and the control of public services, while the regional assembly has wider policy and planning competences. In practice, however, a satisfactory division of duties between both assemblies would prove a thorny problem. Originally, President Mitterand had proposed unification of the two assemblies into a single assemblée, but the Conseil Constitutionnel had rejected this proposal as being unconstitutional. For the institutional organisation of the DoM, the Conseil Constitutionnel gave a restrictive interpretation of Article 73 of the Constitution, allowing little room to adapt to local circumstances. Aldrich \& Connell 1998:25; 1992:79. In 1999 the Lise-Tamaya report (see below) once again placed a single assembly for each DOM on the political agenda. Hintjens 2001:37.

37 See Hintjens 2001:36.

38 'Les départements d'outre-mer aujourd'hui: La voie de la responsabilité', June 1999. Lise and Tamaya also proposed the establishment of a new institution, a Congrès where the departmental and regional assemblies would converge to discuss issues common to both. In the bid to renew the pact with the Republic, the LiseTamaya report had stated that the Dom 'will be allowed the opportunity to endow themselves with an institutional instrument of their own' (quoted in Réno 2001:14). See Hintjens (2001:37): 'Under this new law, each department could move towards a distinctive constitutional status by arrangement. [...] each [DOM] could in theory go their own way. The model is reminiscent of that for Corsica.' The 'Basse-Terre Declaration' presented in December 1999 is also a clear indication of change in the French territories. The desire is now to become a self-governing department with the possibility of regional overtures. See Réno 2001:14-5; Unck 2001:20-1.

39 Quoted in Réno 2001:14.

40 In 2003 the proposal was still under discussion. Project de loi de finances pour 2003, adopté par l'Assemblée nationale - Tome vII : Département d'outre-mer (www.senat.fr/rap, consulted 4-4-2003).

41 See Réno 2001:12-4 and figures provided below.

42 Hintjens 1995:21.

43 See also the comparative paragraphs in Chapters 8 and 9. Under the Treaty of Amsterdam the status of the Dom has become that of région ultrapériphérique (just like the Spanish Canary Islands, and the Portugese Azores and Madeira). Senator for the fourth Dом, Réunion, Jean-Paul Virapoullé recently maintained in no uncertain terms that without Europe, everything would collapse - 'Si l'Europe se retire, il n'y a plus rien!'(L'Express, 7-2-2002).

44 The importation of oil from Trinidad forms the largest part of this regional trade. France has maintained a much tighter grip on the trading activities of its Dom than have the United Kingdom and the Netherlands with respect to their territories. See Burac(1995:102): 'There is a very strong European feeling on the part of local [French West Indian] politicians, and a lack of interest, even some kind of contempt, towards the other Caribbean countries and their people.'

45 Constant 2001:87.

46 For further figures and discussion, see Chapter 8.

47 Miles 2001:57, 59. The last census was taken in 1999: Guadeloupe has 422,496 inhabitants, Martinique 381,427 and Guyane 157,213. Of course, this does not include the Caribbean population in metropolitan France. 
48 'la misère culturelle d'un peuple privé de project' (Le Monde Diplomatique, January 2003, p. 6). Miles 2001:56; Price 1998 :xi-xiii.

49 Quoted in Miles 2001:56.

\section{The Comparative Context: Puerto Rico and the U.s. Virgin Islands, Deadlocks in American Geopolitics}

1 As early as 1902 Puerto Rico declared English an official language (along with Spanish), but the local population is still almost exclusively Spanish-speaking. At present only around ten per cent of the population speaks fluent English, much to American concern; compare Ortega 2001. The contrast with the French model is evident; compare Hintjens 1992:65.

2 In Roosevelt's words: 'so to speak, our show window looking south' (Lewis 1963:122).

3 Only Cuba would soon find independence, in 1901, albeit with the concession that the United States would construct several naval bases and possess the right to intervene, should it see fit. This right to intervene in Cuba was only relinquished in 1934. The Philippines would attain sovereignty in 1946.

4 See Von Albertini 1982:473-4.

5 See Boxill 1993:3-4.

6 Compare García-Passalacqua (1993:177) for the different stages of American policy with regard to the Caribbean. Between 1898 and 1930 American power in the region grew with a succession of military interventions: in Cuba in 1898-1902 and 1906-9, 1912, 1917-1922, in the Dominican Republic in 1905 and 1916-24, and in Haiti from 1915 until 1934. After the construction of the Panama canal, the influence of the European powers diminished as the region's strategic importance to America grew. For an overview of (military) interventions by the United States between 1803-1935, see Maingot 1994:14-45.

7 The Dutch government was exiled from the occupied Netherlands in London at the time; see Chapter 5 .

8 The Commission was set up in March 1942. In October 1946 the Netherlands and France would join its successor the 'Caribbean Commission' until mid-1965, when it was discontinued.

9 See Rodríguez-Beruff 1996:157-8. The bill had been presented against the backdrop of the heavy political crisis of the 1930s. It had also been rejected on the island itself.

Post-World War II the United States would exercise administrative jurisdiction over the 'Trust Territory of the Pacific Islands', a trusteeship created by the United Nations comprising the Northern Mariana Islands, the Marshall Islands and the Caroline Islands. As of the 1970 and 1980 os these islands would either become a U.s. Commonwealth (Northern Mariana Islands) or freely associated states (the Marshall Islands, the Federated States of Micronesia and the Republic of Palau). 10 The current insular governments for which the U.s. Office of Insular Affairs has varying responsibilities include, next to Puerto Rico and the U.s. Virgins Islands, American Samoa, Guam, the Commonwealth of the Northern Mariana Islands (all of which are U.s. territories); as well as the Republic of the Marshall Islands, the 
Republic of Palau, and the Federated States of Micronesia, which are formally sovereign nations linked with the United States through Compacts of Free Association. Recently is has been proposed by the American Secretary of the Interior to dismantle the U.s. Office of Insular Affairs (Ramos \& Rivera 2001a:5).

11 See Carrión 1963:145. At the time all Puerto Rican political parties accepted statehood, but with the adoption of the Foraker Act (1900) they became disappointed with their standing. Compare Knight (1990:267): 'Puerto Rico after 1900 assumed a status similar to that of the District of Columbia in the government of the United States. It could be heard, but it had no vote, even on matters pertaining to its own interests.' The Foraker Act fell short of the freedoms granted to Puerto Rico in 1897 under Spanish rule, but offered better economic stipulations.

12 Proudfoot 1954:351.

13 Thus far the traditional constitutional pattern of the Union had recognised only two basic status types, that of the provisional territory and the fully-fledged state.

14 'The imperialism of neglect had merely been exchanged for the imperialism of liberal paternalism.' Lewis 1963:140.

15 In the Campbell Bill, which had been drafted by the Puerto Rican lawyer Miguel Guerra Mondragón, it was proposed 'to provide an autonomous government for the said island, creating the Associated Free State of Porto Rico' (Carrión 1963: 151).

16 Lewis (1963:3): 'Even when such concessions have been made, they have been not so much the willing grants of imperial imagination (like the retreat of the British Raj from India in 1947) as reluctant acts of a Congressional conservatism.' The reforms were implemented during a phase when America felt obliged to demonstrate its liberal-democratic stance as a contrast to that of imperialist Germany. Still this was a true broadening of self-government, and indeed a big step for Puerto Rico, especially in comparison to the then existent Naval administrations of Guam, Samoa and the Panama canal zone.

It was beyond dispute that Puerto Rico's leading political figure, Luís Muñoz Marín, would become the first elected Governor. In 1940 he had led his party, the Partido Popular Democrático (PPD), to victory and in 1946 had begun searching for a formula which could sidestep the old political dichotomy between independence and statehood. 'In his writings, lectures, and speeches he referred to the British experience with Canada and Australia and set it up as an example that the United States could follow, if statehood was not feasible'(Carrión 1963:157).

171947 was also the year of the doctrine of President Truman: in a message to Congress the president offered all free peoples military and economic help for the upkeep of their independence. See also Maingot 1994:72-3.

18 Carrión 1963:163. The responsible U.s. Senate Committee emphasised that the Act would not alter the subordinate position of the island vis-à-vis the federal government. Beyond that, the Puerto Rican Constitution needed to fulfil two American requirements: it should maintain a Republican form of government and comprise a human rights declaration.

19 See Cabán (1993:21): 'Approximately 20 per cent of the voters rejected that constitution, while independence forces boycotted the referendum.'

20 Quoted in Carrión 1963:167. The architect of the Commonwealth status, Muñoz Marín, defined the significance of the island's new status as follows (1954): 'The most significant aspect of the new status lies in the recognition that the arrange- 
ment is indeed founded on the principle of consent, expressed by a compact in the form of an Act of Congress subject to the approval of the people of Puerto Rico at the polls. Another basic characteristic is the concept of association as distinguished from the historical idea of union, so far as states are concerned, and of possession, so far as unincorporated territories are concerned. It embodies association with the United States, not union among the states. These are the characteristics that clear the status of the former colonial character of "territory" or "possession"' (quoted in Carrión 1963:165-6).

21 Compare Domínguez (1993:16): 'For the United States, the shift toward a commonwealth in Puerto Rico was bolstered by the belief that Puerto Ricans wanted it.' The preamble of the new Constitution stated: 'Whereas, the single word "commonwealth", as currently used, clearly defines the status of the body politic created under the terms of the compact existing between the people of Puerto Rico and the United States, i.e., that of a state which is free of superior authority in the management of its own local affairs but which is linked to the United States of America and hence is a part of its political system in a manner compatible with its federal structure' (quoted in Debrot 1953:165).

Those who had drafted the Constitution had chosen the term 'Commonwealth' in a bid to avoid confusion within the American political system: the new status should not be indicated as a form of state. Since in Spanish there was no equivalent for the word Commonwealth, the phrase Estado Libre Asociado was accepted instead. 22 Cabán 1993:21. The legal association with the United States was for the most part laid down in the Puerto Rican Federal Relations Act (PRFA), whose prime provision stated: 'the statutory laws of the United States not locally inapplicable [...] shall have the same force and effect in Puerto Rico as in the United States, except the internal revenue laws.' American Congress would continue to issue legislation for Puerto Rico in cases of 'general concern' (Wells 1955:81). The Puerto Rican people are thus ruled by two governments, although they lack a Congressional delegation in Washington to look after their interests (the Puerto Ricans, like the U.s. Virgin Islanders, are excluded from participating and voting in presidential and congressional elections unless they move to the continent).

${ }_{23}$ 'The PPD [the pro-Commonwealth party, which participated in the debate] joined u.s. policy-makers in a campaign to mystify the country's colonial status' (Cabán 1993:23).

24 General Assembly Resolution 748 (VIII) of 27 November 1953, quoted in Carrión 1963:166. In January 1953 the United States had already unilaterally crossed Puerto Rico off the U.N. list of Non-Self-Governing-Territories. Compare Aldrich \& Connell (1998:157): 'In the case of Puerto Rico, the United States argued that the United Nations had no authority to review the situation; it submitted the fact of the establishment of the commonwealth of Puerto Rico for information only and stated that the territory was now self-governing [...]. By a very narrow vote, the United Nations agreed to the us position.' Puerto Rico would nevertheless continue to figure yearly on the U.N. agenda, particularly because of America's military presence on the island. A referendum held in 1967, under U.N. pressure, prevented the U.N. relisting Puerto Rico as a non-self-governing-territory: a large majority (60.4\%) had voted for a continuation of the Commonwealth status (albeit with greater autonomy). Since 1952 the U.N. has passed 17 resolutions, each reconfirming the right of the Puerto Rican people to opt for independence.

25 The American representative declared: 'I am authorized to say on behalf of the 
President that if at any time the legislative assembly of Puerto Rico adopts a resolution in favor of more complete or even absolute independence, he will immediately thereafter recommend to Congress that such independence be granted' (quoted in Proudfoot 1954:355).

26 Quotations taken from Ortega 2001:38.

27 Since 1999 there were once again vehement protests in Puerto Rico against the use of Vieques, an island that belongs to Puerto Rico, for training manoeuvres by the U.s. army. Washington conceded on this particular point in 2003. Compare García Muñiz (1991:42): 'U.s. military installations in Puerto Rico have been established without consulting the people of Puerto Rico. "Common defense" with the United States has meant in reality that Puerto Ricans share the consequences of a unilaterally imposed U.s. defense policy.' Trías Monge (1997:161-3) is therefore of the opinion that Puerto Rico remains an American colony. And Lewis (1985:232): 'Both the U.s. Virgin Islands and Puerto Rico are still in colonial status; as a visiting U.s. Senator once remarked in a congressional hearing held in St. Thomas, we are still the chairman of the board. It is estimated that the local Commonwealth government in San Juan lacks jurisdiction in at least thirty-eight areas of public life, including civil aviation, federal labor relations, defense, maritime transportation, and foreign relations [...].'

28 Ramos \& Rivera 2001a:13. The admission of Hawaii (along with Alaska) into the 'family' of American states (1959) had also given a new impulse to the advocates of statehood. For the 1990 os plebiscites, see below.

29 Compare Lewis 1968:401-2, 408. 'Yet the most glaring singularity of the Puerto Rican model and its West Indian imitators is that it proposes to cure the ills of economic colonialism by re-establishing the conditions originally producing them.'

30 During the Cold War Puerto Rico was seen as a prototype of 'modernization of colonialism' (American Congress in 1989, quoted in García-Passalacqua 1993:178). Operation Bootstrap has widely been characterised as a show case to counteract the Cuban revolutionary model.

31 It is estimated that around 300,000 Puertoricans are working in companies which operate under Section 936. In 1993 President Bill Clinton announced that the general exemption from taxes for American companies in Puerto Rico would be replaced by a more restrictive regulation stipulating that companies should pay tax according to the wages paid out. This sharpening of Section 936 was announced within the framework of general federal cutbacks in expenditures. 'Half a Puerto Rican Policy', Washington Post, 24-3-1993; 'Puerto Rico Fighting to keep its Tax Breaks for Businesses', New York Times, 10-5-1993.

32 Ramos \& Rivera 2001a:2-12. Figures taken from the Puerto Rican Planning Board by Ramos \& Rivera 2001a:7. Transfer Payments to Individuals include payments to veterans, Medicare, retirement, social security benefits, scholarships and loans, and various other categories. The other portion of the transfers is directed to Puerto Rican government agencies. The total figure of payments increased from $\$ 4,510$ million (1985) via $\$ 6,058$ million (1990) and \$ 7,698 million (1995) to the \$9,488 million figure projected for 1998 .

33 See, however, García-Passalacqua (1993:174): 'the role of Puerto Rico in the region (and what is most important, its neighbors' perception of that role) would be completely different if the island were a state of the union. It is one thing to be a state of the United States in the Caribbean; it is another thing to be a Caribbean state.' Compare Heine \& García-Passalacqua (1993:210): 'Puerto Rico is not so much 
a tool of U.s. policy as a user of U.s. policy to obtain its own ends.'

34 A major stumbling block in current relations is that the Commonwealth status did not remove Puerto Rico from the territoriality clause of the U.s. Constitution. Puerto Rico is thus still an American territory, and Congress has the final say over the island's affairs.

Puerto Rican party politics essentially revolves around three parties, each being linked to a different constitutional option. The Partido Popular Democrático (PPD) is the party of the founder of the Commonwealth status, Muñoz Marín; the Partido Nuevo Progresista (PNP) advocates statehood; the Partido Independentista Puertorriqueño (PIP) supports full sovereignty for the Puerto Rican people. The PNP was founded in 1967, and in the following year the party forwarded its first Governor. Ever since, the PPD and PNP have alternated in forming the government. The PIP has always remained a small opposition party. Ramos \& Rivera (2001a:12) present a biting comment on the three parties' performance over the past decades: 'In truth, from 1952 to 1999 , the ability of political parties to promote change in the existing political structure has been negligible. Although political parties are identified with status options, they have performed less as mechanisms of political attainment than as mobilising agents for political change.'

35 During the 1980 communism was still seen as the largest threat to the free world and the American government was driven by the necessity to take a firm hold of the Caribbean in order to secure the containment of the Russian influence. President Ronald Reagan was convinced that something needed to be done about the 'benign neglect' of his predecessor President Jimmy Carter in the region. Against this background he developed, in 1982, a sort of Marshall Plan for the Caribbean: the Caribbean Basin Initiative (сві). The Caribbean and Latin America should become capitalistic communities, along the same lines as America and capable of competing in the international export market. Washington at the time considered both regions as an unstable group of dominos ready for a communistic takeover. See Lewis 1985:228-9; García-Passalacqua 1993:182-3; Payne \& Sutton 1993:20-1; Bernal 1995:213-4; Ramos \& Rivera 2001a.

36 Quoted in Díaz 1995:205.

37 Rodríguez-Beruff 1996:160; Gautier-Mayoral 1994:168. The United States had different reasons for wanting to organise a referendum in Puerto Rico, see GautierMayoral 1994:170-3: 'Another reason for the U.s. urgency to hold a plebiscite in Puerto Rico in 1989 could have been the panic of the far right that the U.s. would "lose" Panama and Guantánamo in the year 2000, and its desire to make Puerto Rico a state so that the real estate where the bases are located would always remain part of the United States.'

38 Gautier-Mayoral (1994:174, 168): 'A tie vote of ten to ten in early March 1991 ended two years of congressional hearings at the Senate Energy and Natural Resources Committee [...] on a second (1991) bill for a status referendum. It became apparent that as the dependent Puerto Ricans seemed nearer to asking for statehood, the U.s. Senate had serious misgivings about that possibility.'

39 Resolution 279. Velez 2000:133; Ramos \& Rivera 2001a:12-3. Since Congress is vested with ultimate authority in determining Puerto Rico's legal status, the results of any referendum are necessarily nonbinding. See Morris 1995:62. Compare García-Passalacqua (1993:185): 'The statehood issue is not one of self-determination but one of "mutual determination", since it is the sovereign that must decide whether to admit the island or not.' 
40 See Velez 2000:133, 135; Kerkhof 2000:10-1; Ramos \& Rivera 2001a:12-9. Congress has always rejected the enhanced model of Commonwealth as unconstitutional.

41 See Ortega 2001:30-4.

42 See Ramos \& Rivera 2001a:18-9 for arguments in favour of an enhanced form of free association.

43 Only those changes in the Constitution which are in keeping with the Federal Relations Act, the Federal Constitution and Public Law 600 can be passed without Congressional approval.

44 Some 3.8 million Puerto Ricans are living on the island and over 3 million (Alegría Ortega 2001:37) in the continental United States. See also 'A Comparative Perspective' in Chapter 9.

45 Lewis 1963:411.

46 See Phillips 1991:2. As all other U.s. insular areas, since 1995 the U.s. Virgin Islands come under the jurisdiction of the Interior's Office of Insular Affairs.

47 Phillips 1991:3; Proudfoot 1954:355-6. In 1946 the American President appointed the first coloured Governor (an American) for the U.s. Virgin Islands; in 1950 the first native Virgin Islander was appointed Governor.

48 See Domingo (1991:180): 'In contrast to the growing international emphasis on self-determination, the 1954 Revised Organic Act actually reduced the relative power of the elected legislature on the Virgin Islands and increased that of the presidentially appointed governor, and, therefore, of the president and Congress.' Phillips (1991:3): 'It is felt that this status was bestowed on the Virgin Islands to satisfy Congresspersons who did not wish the Organic Act to be interpreted as a step toward eventual statehood.'

Some fiscal measures to stimulate the economy were also introduced; since 1954 Congress has encouraged the establishment of light industries on the Virgin Islands with generous tax advantages. Federal tax collections on the Virgin Islands are advanced to the general funds of the local government.

49 Text resolution: 'The people of the Virgin Islands desire to have the Virgin Islands remain an unincorporated territory under the constitutional system of the United States with the fullest measure of internal self-government and in the closest association with the United States of America, and the Virgin Islands shall hereafter be designated an "autonomous territory"' (quoted in Phillips 1991:4).

50 Previously this request for direct representation on the continent had been turned down by Congress on the grounds that 'the Virgin Islands are too small and even their existing governmental structure too complicated and expensive to operate'. Proudfoot 1954:356. Congress feared to unchain new requests by other smaller dependencies in the Pacific, which then could no longer be ignored.

51 'Congress has been deliberate and haltering in acting upon other reforms' (Phillips 1991:5).

52 See Domingo 1991:182-3.

53 Quoted in Phillips 1991:6.

54 Quoted in Phillips 1991:6. In actual practice the military role of the U.s. Virgin Islands has been minimal (Domingo 1991:172). In the beginning of 1967 the United States had transferred the possession of the former naval basis in St. Thomas to the local government, but retained the right to take over the basis as and when American security interests would be at stake.

55 See Philips 1991:7. 
56 Figures for U.s. aid to the U.s. Virgin Islands from the Department of Interior Affairs, www.doi.gov/oia/chapter1 (consulted 10-2-2003), 'A Report on the State of the Islands 1997', section 5.4, and 'FY 2000 Performance Report', 'FY 2001 Operating Plan' and 'FY 2002 Annual Performance Plan'.

57 One of the world largest petroleum refineries is at St. Croix.

58 Report on the State of the Islands, Office of Insular Affairs, 1995 (www.doi. gov/oia/chapter1), 10-2-2003. Compare Aldrich \& Connell (1998:18): 'The low turnout [referendum 1993] suggested that only one-quarter of Virgin Islanders were troubled by status issues, and only one-fifth of these wanted any major change. Moves for either statehood or independence, or indeed any dramatic revision in the constitutional status, consequently appear unlikely in the near future.'

59 Kerkhof (2000:11): 'A 1996 report by the General Accounting Office (GAO) estimated that admitting Puerto Rico as a state would cost the us $\$ 13$ billion a year.' It is estimated that the extension of federal taxes to Puerto Rico would result in a yearly contribution to Washington of only $\$ 49$ million.

\section{Dutch Rule in the Caribbean up until 1940: Careless Colonialism}

1 Oostindie 1997:176; Ramsoedh 1990:7.

2 Quoted in Ramsoedh 1990:5.

3 Between 1865 and 1901 the Governor appointed four out of the thirteen Council members.

4 Bossenbroek 1996.

\section{The Dismantling of the Dutch Empire, 1940-1954}

1 Minutes, council of ministers, 26-8-1940 (NA, notulen MR, inv. nr. 246). Memorandum (secret) by Minister C.J.I.M. Welter on the position of the Kingdom after the ending of the war, 10-8-1940 (NA, MinKol Londen, inv. nr. 488).

2 Minutes, council of ministers, 6-5-1941, 8-5-1941 (NA, notulen MR, inv. nr. 246).

3 Quoted in van den Doel 2000:58.

4 Minutes, council of ministers, 2-9-1942 (NA, notulen MR, inv. nr. 246).

5 DBPN 1987:416.

6 Minutes, council of ministers, 2-9-1942, 13-10-1942, 15-10-1942, 22-10-1942 (NA, notulen MR, inv. nr. 246).

7 Netherlands News 5(3)1942:108.

8 Radio speech by Minister H.J. van Mook, 31-12-1942 (NA, Gs, Kab geheim, inv. nr. 258).

9 The subsequent overview of Dutch decolonisation policies in the Netherlands East Indies is mainly based on the recent study by van den Doel (2000).

10 In the spring of 1946, by the end of his term as Minister of Colonial Affairs, Logemann openly acknowledged that most Indonesian intellectuals indeed sided with the Republic, and that a military solution was impossible. Logemann quoted 
in van den Doel 2000:96, 158-9.

11 Quoted in van den Doel 200o:229; see also pp.171, 203.

12 Minister of Colonial Affairs J.A. Jonkman, quoted in van den Doel 200o:166.

13 Quoted in van den Doel 2000:289 and 214, respectively.

14 Quoted in van den Doel 2000:341.

15 Radio speech by Minister J.H.A. Logemann, 10-2-1946 (BZ, code 3, 1945-1954, inv.nr. 4840).

16 Successive Surinamese cabinets after 1954 would use the principle of self-determination as a successful bargaining tool to attain fuller autonomy and next independence.

17 Quoted in Oostindie \& Klinkers 2001, I:64.

18 For more detail regarding the relations with Brazil and particularly Venezuela in the immediate post-war period, see Oostindie \& Klinkers 2001, I, particularly 148-9.

19 Petition by Surinamese Staten, 25-6-1948 (included in appendix documents House of Commons, 1947-1948, part 1, p. 19).

20 Kasteel 1956:134, 137. Letter Governor J.C. Brons to Minister J.A. Jonkman, 3-81946 (NA, Gs, Kab geheim, inv. nr. 177).

21 Mitrasing 1959:69.

22 Coded telegram Friedericy to Minister J.A. Jonkman, 11-7-1947 (NA, MinKol, codetelegr., inv. nr. 11, vol. 23). Telegrams Governor J.C. Brons to Minister J.A. Jonkman, 28-8-1947, 9-10-1947 (NA, MinKol, codetelegr., inv. nr. 11, vol. 22).

23 Minutes, council of ministers, 23-2-1948 (NA, notulen MR, inv. nr.1).

24 Minutes, council of ministers, 23-8-1948 (NA, notulen MR, inv. nr. 1).

25 Minutes, council of ministers, 22-11-1948 (NA, notulen MR, inv. nr. 1).

26 Advice from Surinamese Staten on the draft interim regulation, 6-5-1949 (NA, KMP, 1942-1969, inv. nr. 1996). Advice from the Antillean Staten on the draft interim regulation, 13-10-1949 (Van Helsdingen 1957:81-2).

27 Letter W.C.L. van der Grinten to Minister J.R.H. van Schaik, 1-9-1949 (NA, Van Schaik coll., box II).

28 Paula 1988:60. Interim report commission of reporters, House of Commons, 236-1950 (appendix documents House of Commons, 1949-1950, p. 139).

29 Explanatory memorandum of the Sketch for a Charter regulating the status of the Netherlands, Suriname and the Netherlands Antilles within the Kingdom (NA, KMP, 1942-1969, inv. nr. 1996).

30 Confidential report by Minister J.R.H. van Schaik, undated, on the negotiations which took place with Dutch representatives in the Antilles and Suriname from 12$11 \mathrm{t} / \mathrm{m}$ 3-12-1951 (BZ, code 3, 1945-1954, inv. nr. 4842).

31 Memorandum by J.A.E. Buiskool, 31-12-1951 (BZ, code 3, 1945-1954, inv. nr. 4842). Coded telegram Governor A.A.M. Struycken to Minister L.A.H. Peters, 21-11952 (NA, MinKol, codetelegr., inv. nr.36, vol.17).

32 Minutes, council of ministers, 21-1-1952 (NA, notulen MR, inv. nr. 2).

33 Van Helsdingen 1957:114-8.

34 Letter J.A.E. Buiskool to Governor J. Klaasesz, 14-5-1952 (NA, KG s, inv. nr. 228). 35 Memorandum by A. Jonkers, August 1952 (NA, MinKol, dir. snA, inv. nr. 23). 36 Minutes, council of ministers, 3-6-1952 (NA, notulen MR, inv. nr. 2). Memorandum (secret) Minister W.J.A. Kernkamp to council of ministers, 20-1-1953; memorandum (presumably) by W.H. van Helsdingen (or A. Jonkers), undated (NA, KMP, Fock coll., inv. nr. 8697). 
37 Memorandum of New York, 11-11-1952 (BZ, code 3, 1945-1954, inv. nr. 4853).

38 Memorandum by W.H. van Helsdingen, 29-12-1952 (NA, MinKol, dir. sNA, inv. nr. 23).

39 Resume of the consultations within the Dutch delegation, 12-6-1953 (NA, MinKol, dir. SNA, inv. nr. 23).

40 Letter by the Cabinet of the Governor of the Netherlands Antilles to J.A.J. van Gorkom, 23-1-1954 (NA, KGS, inv. nr. 229).

41 Van Helsdingen 1957:138-40.

42 Van Helsdingen 1957:141-3.

43 Letter Westrik to Governor J.C. Brons, 14-8-1947 (NA, Gs, Kab geheim, inv. nr. 873).

\section{The Failed Attempt at Model Decolonisation, 1954-1975}

1 For a broader understanding of Dutch policies for Suriname and the NetherSuriname), see Oostindie \& Klinkers 2001, II:23-179.

2 See, however, Oostindie \& Klinkers 2001, II:251-300.

3 For a more detailed analysis of the conflicts in Willemstad following the promulgation of the Charter and the ensuing Kingdom interventions, see Oostindie \& Klinkers 2001, II:39-49.

4 Report (confidential) Governor J. van Tilburg to Minister for Surinamese and Antillean Affairs H.A. Korthals, 20-2-196o (NA, KabsNA, inv. nr. 91).

5 Letter Minister of Foreign Affairs J.M.A.H. Luns to Voûte, 19-5-1961 (NA, KabsnA, inv.nr. 91).

6 For a more in-depth analysis of the discussions during the round-table conference, see Meel 1998 and 1999, as well as Oostindie \& Klinkers 2001, II:49-57.

7 Memorandum (secret) K.H. de Boer to Minister H.A. Korthals, 8-4-1961 (NA, KabsnA, inv. nr. 91).

8 Letter Prime Minister E. Jonckheer to Minister H.A. Korthals, 13-6-1961 (NA, KabsnA, inv.nr. 91).

9 Cf. Breeveld 200o. His biographer Hans Breeveld underlines that Pengel aimed for future independence. Some sort of constitutional relation to the Dutch Crown, possibly as in the British Commonwealth, could be preserved, as he declared in 1966. Pengel added, however, that his 'NPs has decided not to force the independence of Suriname, as long as she remains unconvinced that the majority is behind her in this respect' (quoted in Breeveld 2000:232).

10 Memorandum A.J.M. van Nispen to Prime Minister J.E. de Quay, 3-5-1962 (NA, KMP, 1942-1969, inv. nr. 6063).

11 On Pengel's fall, see Sedney 1997:72-9.

12 For the revolt and the Dutch military intervention, see in particular Oostindie 1999a, 1999b and 1999c.

13 For a detailed analysis of the decision making process, see Croese 1998, 1999 and Wessels 1999a.

14 Compare Hoefte 1999.

15 Cf. Excessennota 1995:7-17. 
16 Commissie 1970. For a detailed analysis of the report see Wessels 1999b: 177-84. For further related comments see Hoetink 1999 and Oostindie 1999c.

17 Protocol of consultations held in Willemstad on 29/30-1-1970 (NA, KMP, 19701979, inv. nr. 592).

18 Interview J.A. Bakker, 3-11-1998 (KITLV, Collectie Oostindie \& Klinkers).

19 R.A.J. van Lier, Deventer Dagblad, 25-3-1972 (NA, KG S, inv. nr. 257).

20 R.A.J. van Lier, Deventer Dagblad, 25-3-1972 (NA, K Gs, inv. nr. 257).

21 HтK 1971-1972, nr. 11569 (Report Netherlands Antilles, 31-8 and 3-9-1971).

22 Letter Minister P.J. Lardinois to Prime Minister B.W. Biesheuvel, 13-2-1973 (NA, KMP, 1970-1979, inv. nr. 613).

23 For a more in-depth insight into the den Uyl administration and the independence of Suriname, see Oostindie \& Klinkers 2001, II:114-79; Dew 1978; Fernandes Mendes 1989; Jansen van Galen 1995:123-206; Ooft \& Hendriks 1976.

24 Minutes, council of ministers, 3-9-1973 (NA, notulen MR, inv. nr. 56).

25 Minutes, ministerial social welfare council, 28-1-1974 (NA, notulen Welzijnsraad, inv. nr. 1584).

26 First meeting Prime Minister J.M. den Uyl with the Surinamese council of ministers (top secret), 21-2-1974 (NA, KabsnA, inv. nr. 97).

27 Report Dutch Ambassador in Jamaica to Minister of Foreign Affairs M. van der Stoel, 31-10-1973 (BZ, GS, 1975-1984, inv. nr. 1530). Visit Prime Minister J.M. den Uyl to Suriname, first meeting with representatives of the Surinamese opposition (top secret), 22-2-1974 (NA, Kabsna, inv. nr. 97).

28 First meeting Prime Minister J.M. den Uyl with representatives of the Surinamese coalition parties (top secret), 22-2-1974 (NA, KabsNA, inv. nr. 97).

29 Minutes, council of ministers, 1-3-1974 (NA, notulen Mr, inv. nr. 1400).

30 Meeting Minister W.F. de Gaay Fortman with the Surinamese council of ministers, 11-3-1974 (NA, KabsNA, inv. nr. 68). Minutes, council of ministers, 15-3-1974 (NA, notulen MR, inv. nr. 1400).

31 Koninkrijkscommissie 1974.

32 Koninkrijkscommissie 1974:41.

33 Koninkrijkscommissie 1974:46-51.

34 Jansen van Galen \& Vuijsje 1985:237-8. Pronk was referring to the old DutchReformed Church, where in a special session of the Surinamese Staten the independence procedures would be concluded in the night of 24 to 25 November 1975 . The issue of Suriname's national borders was the final point of contention.

35 Memorandum H.P.J. M. Merckelbach to Prime Minister J.M. den Uyl, 3-12-1974 (NA, KMP, 1970-1979, inv. nr.1210).

36 Memorandum, 26-9-1974 (NA, KMP, 1970-1979, inv. nr. 1210).

37 Fernandes Mendes 1989:99.

38 Azimullah 1986:259-65.

39 Minutes, ministerial commission for the independence of Suriname (MICOs), 19-12-1974 (NA, notulen Micos, inv. nr. 1585).

40 In 2002 the euro replaced the Dutch guilder with a conversion rate of 2.2 guilders per euro. Inflation in the 1975-2002 period happens to be of more or less the inverse magnitude, hence the 19753.5 billion guilders equals 3.5 billion euros today. The euro has roughly achieved parity with the dollar in 2003.

41 HTK, 21, 22 and 23-10-1975.

42 Oostindie \& Klinkers 2001, II:140 (Nooitmeer), 143 (Wijntuin), 145 (Bean), 146-7 (Derby). 
43 Sedney 1997:102-3.

44 Memorandum Prime Minister J.M. den Uyl to Prime Minister H.A.E. Arron, 25-11-1975 concerning the national borders of the Republic (KITLV, Collectie Oostindie \& Klinkers).

45 Interviews C.D. Ooft, 19-4-1998; I. Soemita, 17-4-1998; J. Sedney, 17-4-1998; E.L.A. Wijntuin, 17-4-1998 (KITLV, Collectie Oostindie \& Klinkers).

46 Interviews J.H. Adhin, 9-4-1998; H.A.E. Arron, 20-4-1998; J.H.E. Ferrier, 3-111998; J. Lachmon, 15-4-1998; J. Sedney, 17-4-1998; E. L.A. Wijntuin, 17-4-1998 (кITLV, Collectie Oostindie \& Klinkers).

47 Van Agt in Bootsma \& Breedveld 1999:59.

48 Den Uyl quoted in Gortzak 1978:13.

49 Interview J.P. Pronk, 8-9-1999 (KITLv, Collectie Oostindie \& Klinkers).

5o Den Uyl quoted in Gortzak 1978:12.

51 Van Dam 1999:59. Breedveld \& Jansen van Galen 1996:239.

52 Interviews J.A. Bakker, 3-11-1998; F. van Dam, 22-3-1999; A.P.J.M.M. van der Stee, 15-3-1999 (KITLV, Collectie Oostindie \& Klinkers).

53 Interviews R.F.M. Lubbers, 26-3-1999; J.P. Pronk, 8-9-1999; A.P.J.M.M. van der Stee, 15-3-1999 (KIтLv, Collectie Oostindie \& Klinkers).

54 Report of consultations between Bakker and the Antillean government, as well as the island administrations, 17-10 tot 7-11-1969 (NA, KabsnA, inv. nr. 68).

55 Antillean government declaration, 31-1-1974 (NA, KMP, Merckelbach coll., inv. nr. 4016).

56 Letter H.M. Franssen to J.M. den Uyl, 9-8-1974 (NA, KMP, Merckelbach coll., inv. nr. 4016).

57 Letter J.M.G. Evertsz to J.M. den Uyl, 10-1-1975 (NA, KMP, Merckelbach coll., inv. nr. 4076).

58 Interview J.H.A. Eman, 17-10-1997 (KITLV, Collectie Oostindie \& Klinkers).

\section{The Perpetuation of the Transatlantic Kingdom since 1975}

1 For further reading on Dutch Kingdom policies between 1975-2000, see Oostindie \& Klinkers 2001, III:27-289.

2 In the Staten motions of 19 December 1973 and 12 September 1975 the people of Aruba were promised support in the realisation of 'Separate Status'. The island meetings of August 1974 where representatives of all islands recognised Aruba's right to self-determination were another milestone.

3 Interview J.M.G. Evertsz, 7-1-1998 (KITLv, Collectie Oostindie \& Klinkers).

4 Reports of the discussions, 4-2-1976 and 5-2-1976 (NA, KMP, Merckelbach coll., inv. nr. 4076). Coded telegram W.F. de Gaay Fortman to Governor B.M. Leito and Premier J.M.G. Evertsz, 6-2-1976 (KabnA, box 482).

5 Coded telegram J.P. Elzerman (from Oranjestad), 23-8-1977 (NA, KMP, Merckelbach coll., inv. nr. 4075).

6 ANP-report, 4-9-1977 (NA, KMP, Merckelbach coll., inv. nr. 4075).

7 Interview A.P.J.M.M. van der Stee, 15-3-1999 (KITLv, Collectie Oostindie \& Klinkers).

8 Minutes of the discussions on 19 and 20 April 1978 in Willemstad (KMP, Merckelbach coll., not inventorised; KWG collection). 
9 A.P.J.M.M. van der Stee (HTK, 17-5-1978, pp. 2417, 2421).

10 Koninkrijkswerkgroep 1980:44.

11 Memorandum B.H. Adam to A.P.J.M.M. van der Stee, 23-11-1979 (KMP, Merckelbach coll., not inventorised). Koninkrijkswerkgroep 1980:36, 151-2. Interview J.H.A.Eman, 17-10-1997 (KITLv, Collectie Oostindie \& Klinkers). 12 RTC 1981:119.

13 Don Martina, pp. 9, 11-4. Report of consultations between delegations of the Antillean government and the Kingdom government, 26-10-1981 (КМР, 1980-1984, inv. nr. 1546).

14 J.M. den Uyl (нтк, 27-1-1982, p. 1556). Report of consultations between delegations of the Antillean government and the Kingdom government, 26-10-1981 (KMP, 1980-1984, inv. nr. 1546).

15 Betico Croes (RTC 1983:8).

16 R.F.M. Lubbers (RTC 1983:86-7).

17 Betico Croes (RTC 1983:89).

18 Interviews N.O. Oduber, 16-10-1997 and M. Pourier, 20-10-1997 (KITLV, Collectie Oostindie \& Klinkers).

19 Het Parool, 15-2-1995.

20 Memorandum in reply to the Senate, 17-3-1988 (20 200 IV, nr. 147a). Interview A.G. Croes, 22-8-2000 (KITLV, Collectie Oostindie \& Klinkers).

21 'Discussion memorandum regarding Dutch policy for the Antilles in the longterm', Cabinet for Antillean and Aruban Affairs, 2-12-1987 (вZк, current archive). Quotations from pp. 8 and 32.

22 NRCHandelsblad, 28-3-1991.

23 'Conferentie', p.1(Kitlv, Collectie Oostindie \& Klinkers).

24 'Conferentie', pp. 40-1 (KITLv, Collectie Oostindie \& Klinkers).

25 'Conferentie', pp. 101-5 (KITlv, Collectie Oostindie \& Klinkers).

26 'Conferentie', p. 106 (KITLV, Collectie Oostindie \& Klinkers).

27 Interview A.G. Croes, 22-8-2000 (KITLV, Collectie Oostindie \& Klinkers). NRC Handelsblad, 11-3-1993, 12-3-1993; de Volkskrant, 12-3-1993; Nederlands Dagblad, 12-31993; Trouw, 16-3-1993.

28 R.F.M. Lubbers, NRC Handelsblad, 11-3-1993.

29 Interview D. de Gooijer, 30-1-1998 (KITLV, Collectie Oostindie \& Klinkers).

30 Interview A. G. Croes, 22-8-2000 (KITLV, Collectie Oostindie \& Klinkers).

31 Interview E.M.H. Hirsch Ballin, 8-2-200o (KITLv, Collectie Oostindie \& Klinkers).

32 Interviews R.F.M. Lubbers, 26-3-1999; M.Ph. Liberia-Peters. 12-1-1998; S. Römer, 24-10-1997 (KITLv, Collectie Oostindie \& Klinkers).

33 In the 1990s the pivotal position of the major Christian democratic parties, organised in the CDA, was broken by two successive 'purple' cabinets of the social democrats (PvdA), conservative liberals (vvD), and the intermediate left-liberal party D66. In 2002 the CDA regained it central position.

34 J.J.C. Voorhoeve (HTK, 24-10-1995, pp. 1081-2).

35 J.J.C. Voorhoeve (HEK, 16-4-1996, p. 1466).

36 Draft report Koerten, March 1995 (KITLv, Collectie Oostindie \& Klinkers).

37 De Volkskrant, 18-11-1996.

38 NRCHandelsblad, 30-11-1996.

39 In 1999 the Dutch aid budget was enlarged with $€ 35$ million to this end.

40 Meanwhile a confidential Dutch report drew mixed conclusions on the internal 
efficiency of the guard in its first five years of existence. Antilliaanse Nieuwsbrief 42(6), 2001; Amigoe di Curaçao, 6-7-2002.

41 Interestingly, the Antilliaanse Nieuwsbrief 43(1), 2002 published by the Cabinet of the Antillean Plenipotentiary Minister in The Hague, emphasises precisely this economic significance.

42 In contrast to rice, sugar is a product in which the Netherlands itself has a vested interest, being a producer of beet sugar.

43 At the start of the cabinet this minister was Bram Peper. After his premature resignation he was succeded by Klaas de Vries, thus leaving two namesakes in charge. According to his civil servants, Klaas de Vries' involvement in defining the broader policy lines was more profound than publicly visible.

44 The report on the Antilles, Ontwikkeling in vertrouwen (1997), was written by a commission chaired by the Antillean member of the Council of State of the Netherlands, Gilbert Wawoe. The report on Aruba, Op eigen benen (1997), was written by a commission chaired by the former Dutch Prime Minister and Minister Barend Biesheuvel.

45 In domestic Dutch policies too, over the last decade ever more emphasis has been placed on demands such as efficiency, accountability et cetera as criteria for the performance of the civil service. Thus also government agencies concerned with development aid in general, or indeed Antillean and Aruban affairs, have to account for their own performance under this tightened frame of reference.

46 A fuller discussion of the figures for Dutch aid is provided in Chapter 8.

47 Email correspondence and personal conversation with Carel de Haseth and Gijs de Vries, March-April 2003. The views of these two protagonists remain diametrically opposed on this subject. In the Antillenmonitor, 12-2-2003, the Dutch economist Louis Emmerij, former president of the $\mathrm{OECD}$, presented a very critical assessment of the Dutch position. Most of the promised 214 million Dutch guilders was indeed paid out as budgetary assistance. The part not made available as such after the IMF trajectory had been suspended was eventually used in 2001 for other purposes, namely to make up for losses incurred after the September 11, 2001 terrorist attack and the ensuing slack in tourism. The negative growth of the Antillean GDP was six per cent in 1999 and 2000; the performance improved to zero growth in 2002.

48 Based on email correspondence and conversations with Carel de Haseth and Gijs de Vries, March-April 2003.

49 For more on this issue, see Chapter 8.

50 Gijs de Vries in NRC Handelsblad, 3-5-2002. Rapport Waarheidscommissie/Comision di Berdad, 'Een kwestie van mentaliteit. Bestuur en integriteit op Aruba', June 2002 (KITLV, Collectie Oostindie \& Klinkers). Questions by P. Rosenmöller (GroenLinks) answered by Minister Johan Remkes (HTK 2001-2002, Aanhangsel, no. 1555, pp. 3299-3300). Distrust was vehemently voiced by Pim Fortuyn, who early in 2002 openly characterised the Antillean political elites as corrupt and advised that they should be jailed. Fortuyn in radio programme 'Business class', 5-2-2002, printed in Algemeen Dagblad, Caribische editie, 8-2-2002; caustic reaction by De Haseth to Algemeen Dagblad, email 8-2-2002 (KITLv, Collectie Oostindie \& Klinkers).

51 For more on this issue, see Chapter 9. Perhaps Dutch rhetoric on 'drastic measures to be taken to curb migration' was in itself a factor contributing to the Antillean exodus, with Antilleans fearing to lose the opportunity to settle in the metropolis without having to meet prior conditions. There is an apparent parallel 
to the pre-independence Suriname exodus here.

52 For more on this issue, see Chapter 10.

53 NRC Handelsblad, 3-5-2002. Email correspondence and personal conversation with Carel de Haseth, March-April 2003. De Vries wrote more favourably about bilateral accomplishments in a liber amicorum for the outgoing Governor of the Netherlands Antilles, Jaime Saleh, and one for Prime Minister Miguel Pourier (de Vries $2002 a$ and $b$ ).

54 Regeerakkoord 2002-2006; Akuerdo di Ansinghstraat [May 2002] (KITLV, Collectie Oostindie \& Klinkers). Cf. The Daily Herald (St. Martin), 29-5-2002. Incidentally, the restructuring process of Antillean national finance initiated in the late 1990 gave renewed impetus to St. Martin's drive for a separate status, as many St. Martiners attributed the 'ownership' of the problem of an overgrown state bureaucracy and an unbalanced budget to Curaçao rather than to all Antillean islands.

55 Email correspondence, 30-4-2003.

56 The Ministry of Foreign Affairs did provide the Caribbean countries of the Kingdom some new opportunities to present their own interests in the region, e.g. by placing a prominent Antillean representative in the Caracas embassy. Such measures were in accordance with the intentions laid down in the 1998 policy document of the Ministry (Caraibisch Gebied 1998).

57 Regeringsverklaring 2002. Regeerakkoord 2003. All government declarations are in the library of the Dutch Government Information Service (RVD) in The Hague. See also 'Werken aan vertrouwen, een kwestie van aanpakken. Strategisch akkoord voor kabinet CDA, LPF, vVD (3 juli 2002)' (KITLV, Collectie Oostindie \& Klinkers).

\section{Illusions and Benefits of 'Reciprocal Assistance': Development Aid}

1 For a more in-depth approach to Dutch development aid for Suriname, the Netherlands Antilles and Aruba between 1940-2000, see Oostindie \& Klinkers 2001, I:155-62 (1940-1954); II:181-210 (1954-1975); III:291-318 (1975-2000).

2 Figures derived from Bulmer-Thomas 2001.

3 Figures provided by the World Bank for GNI per capita in 2001 (GNI is the gross national income, converted to U.s. dollars using the World Bank Atlas method, divided by the midyear population). Much of the sovereign Caribbean would fit into the World Bank category of Middle Income Countries ( $\$ 1,85$ o per capita GNI), with countries such as Barbados $(\$ 9,250)$ and Trinidad and Tobago $(\$ 5,540)$ easily falling into the Upper Middle category $(\$ 4,460)$; Haiti $(\$ 480)$ and Guyana $(\$ 840)$, however, fall into the Low $(\$ 430)$ and Lower Middle $(\$ 1,240)$ category, respectively. According to the World Bank, Suriname $(\$ 1,690)$ fits somewhere in between the Lower Middle and Middle Income categories. By comparison: the 2001 per capita GNI figure for Latin America and the Caribbean as a whole is $\$ 3,560$; for South Asia \$450, for sub-Saharan Africa \$470, for East Asia and the Pacific \$ 90o. The world average is $\$ 5,140$. Figures taken from the World Development Indicators database, www.worldbank.org, consulted 20-2-2003.

4 Contrary perhaps to common expectation, small-scale does not necessarily imply poor economic performance (Armstrong et al. 1998). Yet econometric analy- 
sis strongly suggests that a non-sovereign constitutional status is a crucial positive factor in the economic performance of micro-states (Armstrong \& Read 200o). The results of the research project led by Bulmer-Thomas do not allow for the isolation of one single factor determining the economic performance of individual Caribbean states. Bulmer-Thomas (2001) nor Nicholls (2001) singles out constitutional status as an independent variable in their modelling. It should perhaps be underlined that scale alone is no decisive factor, and in fact in the Caribbean context precisely the three largest, or at least most populated countries - Cuba, the Dominican Republic and Haiti - are among the worst performers.

5 See Chapter 9 for a more extensive analysis.

6 In 2001 the unemployment rate on Curaçao was $16.4 \%$ (against $14.7 \%$ in 2000 and $15.2 \%$ in 1999). www.zakelijkcuracao.nl (consulted 2-3-2003). Свs figures for Curaçao are slightly lower (14.2\% in 2001, 15.6\% in 2002; Amigoe, 9-4-2003). A survey by the European Commission (see table in NRC Handelsblad, 5-8-2002) puts the EU average at $7.6 \%$. As far as the Doм are concerned, Réunion tops the list with $33.3 \%$, followed by Guadeloupe and Martinique with $29.0 \%$ and $26.3 \%$, respectively. Additional information provided by the French Ministère de l'outre-mer (email 17-32003) adds French Guyane to the list with 30\%, a figure also given in most press publications for Guadeloupe and Martinique. Puerto Rican unemployment figures are derived from www.bls.gov.lau (consulted 4-3-2003).

Unemployment figures are notoriously difficult to establish and compare between states. It may be argued that because of less advanced bureaucracies, sovereign Caribbean nations may understate their unemployment figures.

7 The usage of the concept of reciprocity as a leading principle may surprise specialists in development relations. The fact that the Antilles in the mid-195os had a higher per capita income than the Netherlands probably did stimulate the incorporation of this in hindsight illusory concept, apart from its rethorical significance. Technically, the Netherlands have at times requested support - implicitly refering to the reciprocity clause - from the Antilles and Aruba, particularly in the field of migration policies and the combat of narcotrafficking.

8 In the Netherlands, per capita GDP in 1995 prices increased from $€ 2,817$ (1945) via $€ 7,567$ (1955) and $€ 14,138$ (1975) to $€ 22,771$ (2000); figures of the Dutch Centraal Bureau voor de Statistiek (св), ввP tijdreeks, provided 27-2-2003. Per capita GNI in the Netherlands is set around \$24,0oo by the World Bank.

9 Figures for the Netherlands Antilles ranging from $\$ 11,400$ (www.cia.gov, consulted 4-3-2003) to \$13,240 (www.zakelijkcuracao.nl, consulted 4-3-2003). CIA figures put the per capita GDP in Aruba at \$28,0oo, yet as the population figure is set at 70,000 rather than the more reasonable 90,000 plus, this figure should probably be lowered to some \$20,000 (www.cia.gov, consulted 4-3-2003). Figures for Suriname from Bulmer-Thomas (2001) (see our Table 1) and www.worldbank.org, consulted 4-3-2003. Historical figures for the Antilles and Aruba taken from Haan 1998:21, 83-4, 234. Figures for 2000 - GNI rather than GDP - taken from the Worldbank (www.worldbank.org), consulted 20-2-2003. According to these figures, annual per capita economic growth in the Netherlands was $1.8 \%$ in the 1980 and $2.2 \%$ in the 1990 as against $2.8 \%$ and $3 \%$ for Suriname. For the Antilles in the 1980 os a figure of $2 \%$ is provided, none for the 1990 or or for Aruba.

10 M.A. Karamat Ali versus L. Götzen, secret minutes of a meeting in Paramaribo, 29-4-1951 (NA, Gs, Kab geheim, inv.nr. 193).

11 If the budget for cultural assistance is deducted from the total, the proportion drops to some $85 \%$. 
12 On the links from the Dutch late-nineteenth and early-twentieth-century colonial 'ethical policy' in Indonesia to the post-World War II move towards development 'aid' and next 'cooperation', see Dierikx et al. 2002.

13 With the independence of Suriname the norm was obviously lowered. The proportion was fixed at five per cent of the total Dutch budget for development aid in the 1980 os and afterwards altogether skipped, simply because the amounts to be allocated under such norms were considered to exceed the absorbing capacity of the local economies.

14 NA, minutes MR, 21-11-1969, 29-8-1969, inv.nr. 10. Explanatory memorandum 1970, nr. 7, p. 5 .

15 NA, minutes Mr, 3-9-1973, inv.nr. 56. HTK, 18-11-1971, pp. 1206-7. NA, minutes MICOS, 19-12-1974, inv.nr. 1585 .

16 In 2002 the euro replaced the Dutch guilder with a conversion rate of 2.2 guilders per euro. Inflation in the 1975-2002 period happens to be of more or less the inverse magnitude, hence the 19753.5 billion guilders equals $€ 3.5$ billion today. The euro has roughly achieved parity with the dollar in 2003.

17 NA, minutes MR, 10-5-1974, inv.nr. 1403; 17-6-1974, inv.nr. 1404. Jansen van Galen \& Vuijsje 1985:236.

18 See for the full text Ooft \& Hendriks 1976:105-7.

19 Interview H. Arron, 20-4-1998 (KITLV, Collectie Oostindie \& Klinkers). NA, minutes MICOS, 17-6-1975, inv.nr. 1883.

20 Interview F. van Dam, 22-3-1999 (KıтLv, Collectie Oostindie \& Klinkers).

21 www.minbzk.nl, under 'Aruba en de Nederlandse Antillen' (consulted 20-22003). The text was maintained until at least our latest consultation, 12-8-2003.

22 In 1998 an extra 70 million guilders was allocated for various purposes including hurican relief. In 1999 an extra 80 million guilders was allocated for the Koraal Specht prison in Curaçao and 50 million for hurican relief. In 2000214 million was reserved for budgetary assistance to the Antillean government in the IMF trajectory (a modest part of this was not made available in the end). In 2001 a near 12 million guilders was allocated to make up for losses incurred after the September 11, 2001 terrorist attack and the ensuing slack in tourism. In 2002 an additional 11 million guilders was booked for additional social spending. Figures provided by the Ministry of the Interior and Kingdom Relations, April 2003.

23 It is of course not evident whether the Dutch, should Suriname have remained within the Kingdom, would have been prepared to allocate per capita aid to Suriname - and indeed to the islands - to the same extent as has been the case for the Antilles and Aruba after 1975 .

24 First the West Indian offices of the Ministry of Overseas Territories, next Overseas Parts of the Kingdom and Overseas Affairs; then the Cabinet of the Deputy Prime Minister followed by the Cabinet of Surinamese and Antillean Affairs, next 'Antillean Affairs' and finally renamed 'Antillean and Aruban Affairs'. Since 1998 the Antillean and Aruban Affairs are under the responsibility of the directorate for Kingdom Relations of the Ministry of the Interior and Kingdom Relations.

25 Cf. Haan 1998.

26 E.g. Toekomst in samenwerking 1999.

27 HTK, 18-1-1977, pp. 2520, 2526. Explanatory memorandum Dutch national budget for 1979 .

28 NAR 1978. Gemengde Commissie 1979.

29 See Oostindie \& Klinkers 2001, III: 386-9 for further details on de Koning. 
30 Explanatory memorandum to the Senate, 9-5-1990 (1989-1999, 21300 IV, nr. 200a). Explanatory memorandums national budget, 1991, 1992, 1993.

31 Interview J.J.C. Voorhoeve, 14-8-2000 (KITLV, Collectie Oostindie \& Klinkers). 32 Schuld of toekomst 1996:29-30. The commission was chaired by Dutch top diplomat Emile van Lennep.

33 One commission was chaired by the Antillean member of the 'Raad van State' (the Netherlands' government's Council of State) Gilbert Wawoe, the other by former Dutch Prime Minister Barend Biesheuvel.

34 Toekomst in samenwerking 1999. The report drew heavily on the work of the above listed commissions, as well as on a doctoral thesis by Haan (1998) with devastating conclusions on protectionist Antillean economic policies and much praise for the Aruban trajectory.

35 See Chapter 7.

36 NRC Handelsblad, 3-5-2002.

37 Email correspondence and personal conversation with Carel de Haseth, MarchApril 2003.

Early in 2002, the leading Curaçaoan banker Lio Capriles broke with tradition and wrote an open letter to the Dutch cabinet, stating that by continuing to 'withhold' aid from the Antilles lest first the strict IMF regulations would be met, the Dutch were intentionally ignoring their duties as formulated in the Charter to guarantee good governance. He elaborated on the sorry state of education, on growing poverty and on the lack of social adjustment programmes. Facing deep economic crisis and with no means of its own, he argued, the Antillean government had insufficient capacity to honour its outstanding debts, much less could it secure good governance. Thus Willemstad could not but request additional Dutch aid. Capriles felt the Dutch refusal to lend a helping hand to be a slap in the face, a failure to comply with the words and spirit of reciprocity and mutual trust expressed in the Charter. The letter had no impact in the Netherlands, except perhaps the muttering in The Hague that this banker should reassess his own protectionist policies rather than demand Dutch help. Open letter Lio Capriles to the Dutch government, Curaçao 22-1-2002 (KITLV, Collectie Oostindie \& Klinkers).

38 Troonrede 2003. TK 2002-2003, 28600 IV, Begroting voor het jaar 2003, Koninkrijksrelaties.

39 Interview M. Pourier, 20-10-1997 (KITLV, Collectie Oostindie \& Klinkers). 40 Dependency relations outside of the Caribbean fall outside the scope of this study. However, in a European context, there are interesting parallels between the Dutch-Antillean relations and those between Denmark and Greenland and the Far Oer Islands.

41 Le Monde, 20-9-2002. Behind this decision towards a 'passport mobilité' are two equally characteristic motivations. There is the ideological one, 'ce sont des Français comme les autres', they are French like everyone else and thus entitled to services such as these. And there is the economic motivation, which tells much about French protectionist leanings: the measure also responded to considerable decrease witnessed in the previous years of flights booked - of course with Air France- between the departments and the metropolis.

42 The Dutch and British territories are associated with the Union, while the French departments are fully incorporated and thus entitled to more aid, e.g. from the budget for poorer regions 'within' Europe.

43 Per capita transfers in 2001 in euros are (French contribution, European 
contribution, total, resp.) for Guadeloupe $2,643+281=2,924$, for Guyane $3,358+382=3,740$, for Martinique $3,556+263=3,819$. For Réunion this is $4,551+223=4,674$ euros. The European contribution to the latter island is less than $5 \%$ of the total transfers. Figures for European transfers mainly calculated from table 'Financement au titre des Docup pour 2000-2006' www.senat.fr/rap (consulted 11-4-2003). Figures for French transfers calculated from information provided by the French Ministère de l'Outre-Mer, 18-4-2003, calculations confirmed, 6-5-2003, 23-5-2003, 25-9-2003. No allowance made for taxes collected in the DOM. 44 Per capita GDP figures for 2001 provided by the French government (not concordant with the figures in Table 1 and taken from World Bank and other international sources). In this listing, Guadeloupe $(\$ 12,480)$ and Martinique $(\$ 14,352)$ rank far above Dominica $(\$ 5,425)$, Barbados $(\$ 8,600)$, St. Lucia $(\$ 4,389)$, Puerto Rico (\$ 9,472), Cuba (\$ 737), Haiti (\$ 460) and Jamaica (\$2430). Likewise, French Guyane (\$13,465) above Guyana $(\$ 760)$ and Suriname $(\$ 1,540)$; and Réunion $(\$ 11,421)$ above Mauritius $(\$ 3,540)$, the Seychelles $(\$ 6,500)$, the Comoros $(\$ 350)$, Madagascar (\$250) and South Africa (\$3,170). Source: www.senat.fr/rap (consulted 11-4-2003).

45 Figures for U.s. aid to Puerto Rico taken from Ramos \& Rivera 2001a:7, for the U.s. Virgin Islands from the Department of Interior Affairs, www.doi.gov/oia/chapter1 (consulted 10-2-2003), 'A Report on the State of the Islands 1997', section 5.4, and 'FY 2000 Performance Report', 'FY 2001 Operating Plan' and 'FY 2002 Annual Performance Plan'. Puerto Rican GNI per capita, 2001 taken from www.worldbank.org (consulted 20-2-2003). For a higher estimate, see Table 1. On the report of the General Accounting Office (GAO) and Velazquez' reaction, see Kerkhof 2000:11 and the San Juan Star, 6-9-1996. Personal federal income taxes would amount to a mere $\$ 49$ million. U.s. Virgin Islands' GDP p.c. in 2000 at \$13,139 (www.pacificweb.org, consulted 4-3-2003), respectively at \$19,464 (www.usvi.org, consulted 3-3-2003).

46 The Government's Expenditure Plans 2002-2003 to 2003-2004 (www.dfid.gov. uk, p. 78, consulted 6-2-2003. Foreign and Commonwealth Office 1999:30. The British budget for 2003 allocates some $£ 40$ million for development aid to all British отs, thus including Gibraltar and the Falkland Islands. By way of comparison: this would amount to $€ 335$ per capita if the aid would have been evenly allocated to all отs, quod non. The website of the Department for International Development (DFID) provides figures for bilateral aid for the respective territories (www.dfid.gov.uk, consulted 6-5-2003). In 2000 the Turks and Caicos Islands received some $€ 500$ per capita, Anguilla $€ 600$. Figures for the British Virgin Islands confirm the British claim that these islands were graduating from aid. For Montserrat we calculated an astonishing $€ 14.500$ per capita. This figure is, however, highly inflated due to the cost incurred in the wake of the devastating volcano crisis (1995-1998) and the fact that the new population figure is based on the exodus caused by this disaster. For a general analysis of the post-war economic development of the former British West Indies, see Payne \& Sutton 2001.

47 The volcanic eruptions began in 1995. Since then Montserrat received nearly $£ 60$ million in the first three years of the crisis and has been allocated a further $£ 75$ million for the following three years (www.fco.gov.uk, 11-11-2002).

48 The UK spends around 11 million pounds on education throughout both the sovereign and non-sovereign Anglophone Caribbean per year (www.fco.gov.uk, 1111-2002). 
49 Cf. Table 1. Montserrat with its much lower income is the one exception to the rule.

5o According to Antillean figures, Dutch aid amounts to less than ten per cent of the Antillean government budget. Email Plenipotentiary Minister Carel de Haseth, 7-2-2003 (KITLV, Collectie Oostindie \& Klinkers).

\section{A Caribbean Exodus}

1 For further information regarding the Dutch approach to Caribbean immigration, see Oostindie \& Klinkers 2001, II:225-50 (1954-1975); III:333-56 (1975-2000). 2 www.worldbank.org/data/countrydata/countrydata, 12-2-2003 (419.000 inhabitants in 2001).

3 For the Antilles, see www.werktraject.werk.nl/werk.nlnew/buitenland/wereld/ na-wl.asp (consulted 2-3-2003). For Aruba, see the website of the Cabinet of the Plenipotentiary Minister, www.arubahuis.nl/jz-woonwerk (consulted 2-3-2003). Dutch citizens born outside of Aruba are treated as foreigners, and thus will need to apply for temporary work and residence permits, although Antilleans as well as European Dutch are entitled to a tourist stay in Aruba of up to six months without a visa.

4 'The inhabitants of Curaçao and Aruba are European citizens within the meaning of Article 17 of the Ec Treaty. Theoretically, the nationality of the Kingdom of the Netherlands could be split into three subnationalities, but I cannot conceive of any federal legislation (or "Kingdom Act”) that would achieve this purpose.' Hirsch Ballin 2001:25.

5 The 'Indonesian' community in the Netherlands, numbering just over 400,000, is actually counted among the 'Western' migrants. Bevolkingsatlas 2003:149-50. For the early history of colonial and post-colonial immigration into the Netherlands, see Oostindie 1988 and Willems 2003.

6 See graph in Bevolkingsatlas 2003:111.

7 www.cbs.nl, consulted 26-2-2003; Bevolkingsatlas 2003:148-61; also NRC Handelsblad, 30-7-2002. Figures from Amsterdam's Bureau of Statistics quoted in NRC Handelsblad, 7-2-2003.

8 Report Minister of Justice I. Samkalden, 1-7-1958 (KabNA, inv.nr. 1024).

9 Memorandum (confidential) Governor J. van Tilburg to Minister H.A. Korthals, 20-2-1960 (NA, KabsNA, inv.nr. 91).

10 Minutes, council of ministers, 31-8-1962 (NA, notulen MR, inv.nr. 6). During the 1990 The Hague would once again seriously protest against Antillean and Aruban immigration laws for fellow Kingdom citizens and demand 'reciprocity' in terms of immigration policies, which in the Dutch view should result in the unconditional right of abode for metropolitan citizens on the islands.

11 Memorandum mr. W. Duk to secretary general Ministry of Justice, 2-1-1963 (NA, MinKol, afd. wJZ, inv.nr. 24). Only forty years later would full British citizenship be restored (and so the right of abode in the United Kingdom) for residents in the remaining British territories.

12 See advice A. Jonkers to Minister for Surinamese and Antillean affairs B.W. Biesheuvel, 21-3-1966 (NA, KabsnA, inv.nr. 1027). 
13 HTK 1971-1972, nr. 11551 (Report Suriname, 28-8-1971) and nr. 11569 (Report Dutch Antilles, 31-8-1971 and 3-9-1971).

14 Minutes, ministerial social welfare council, 24-5-1972 (NA, notulen Welzijnsraad, inv.nr.1584).

15 Minutes, ministerial social welfare council, 28-1-1974 (NA, notulen Welzijnsraad, inv.nr. 1584).

16 Minutes, council of ministers, 10-5-1974 (NA, notulen MR, inv.nr. 1403).

17 Ooft 1976:73.

18 Minutes (top secret) bilateral consultations, 24/26-3-1975 (NA, KabsnA, inv.nr.

97).

19 HтK, algemene politieke en financiële beschouwingen, 1974, p. 406.

20 Minutes, council of ministers, 2/3-9-1974 (NA, notulen MR, inv.nr. 1407). It is to be noted that the Dutch cabinet was not unanimous: both the Minister of Justice Dries van Agt and the Minister for Housing Hans Gruijters were always outspoken advocates of a restrictive immigration policy.

21 Interview J.P. Pronk, 8-9-1999 (KITLv, Collectie Oostindie \& Klinkers). With 'the crisis of 1980 ' Pronk was referring to the military coup in that year, which was followed by political murders, internal warfare and other worrisome developments. 22 Interviews J.H. Adhin, 9-4-1998; J. Lachmon, 15-4-1998; E.L.A. Wijntuin, 17-41998 (кITLv, Collectie Oostindie \& Klinkers).

23 Figures from 'Voorlopig rapport inzake de voogdijregeling' (2003) provided by the Cabinet of the Plenipotentiary Minister of the Netherlands Antilles.

24 Central Bureau for Statistics of the Dutch Antilles, Antilliaanse Nieuwsbrief 43 (4) 2002.

25 Figures from Justitiële Verkenningen 28 (1) 2002, p. 5.

26 Report Ministry for Social Affairs and Employment, 1-10-1985 (KMP, 1985-1989, inv.nr.3420).

27 Explanatory memorandum to the national budget for 1993.

28 Consultations, 21-2-1996 on the evaluation of the policy plan 1993-1997 of the Task Force (TK, 1995-1996, 24 400 IV, nr. 14).

29 Central Bureau for Statistics of the Dutch Antilles, Antilliaanse Nieuwsbrief 43 (4) 2002.

30 Interview J.J.C. Voorhoeve, 14-8-2000 (KITLV, Collectie Oostindie \& Klinkers). 31 For the time being, the right of abode is not reciprocated. Whereas Antilleans and Arubans now are free to settle in any European Union country, the reverse is not the case.

32 Cf. Adviescommissie 2001.

33 Email correspondence and personal conversation with Carel de Haseth, MarchApril 2003.

34 Antilliaanse Nieuwsbrief 43(2) 2002. www.cbs.nl, consulted 26-2-2003.

35 See the Epilogue and Oostindie \& Verton 1998.

36 Conway 200o:8o-1; Grosfuegel 1997:64-5.

37 Estimations of the total of British West Indian migration to the metropolis in the period 1951-1961 vary between 230,000 and 280,00o. Richardson 1989:216.

38 Helen Hintjens \& Dot Hodge, paper presented at the Conference on 'Comparing “Colonialisms” in the Caribbean in the $21^{\text {st }}$ century', Institute of Commonwealth Studies, 6-4-200o, p. 5 .

39 White Paper Partnership for Progress and Prosperity, Foreign and Commonwealth Office 1999:18. 
40 Le Nouvel Observateur, 5-12-2002: in 1999 212,000 citizens born in the Dом were living in la France Métropolitaine. Population figures for Guadeloupe (431,000; 2001 est.) and Martinique (414,0oo; July 2000 est.) derived from www.worldatlas.com (consulted 2-3-2003). Statistics suggest that emigration from Guadeloupe and Martinique is on a par with immigration, with net migration rates of $-0.15 / 1,000$ pop.(2001 est.) and 0.09/1,000 pop.(2000 est.), respectively. From the lesser densely populated French Guyane on the other hand (172,605; July 2000 est.), relatively few people migrate to the metropolis. Rather than with emigration, the territory has to deal with a considerable number of (illegal) immigrants, mainly from Brazil, Haiti and Suriname.

41 Hintjens 1991:44.

42 In 1963 the recruitment of workers from the Dom was organised through the institution, under the Ministry of Economic Affairs and Finances, of the 'Bureau pour le Développement des Migrations des Départements d'Outre-Mer' (BUмIDOM). Between 1961 and 1981 under вUмIDом a yearly quotum of 5,00o migrants would arrive in the metropolis. In 1982 the organisation was disbanded.

43 See Anselin 1995:117.

44 The current unemployment rate in Guadeloupe is somewhere between $26 \%$

and $31 \%$, the rate on Martinique is $26.3 \%$. Le Nouvel Obervateur, 5-12-2002; Le Monde Diplomatique, 6-1-2003. The unemployment rate in French Guyane is slightly lower, at $21.4 \%$ (1998 est.) www.worldatlas.com (consulted 2-3-2003). In contrast, France's unemployment rate is $9.5 \%$ (200o), see www.hdr.undp.org/reports/global/2002/ (consulted 2-3-2003).

45 Ortega 2001:37.

46 Note the parallel with France's вuміDом for the promotion of migration to France from the DOM. The establishment of this organisation had been inspired by the Puerto Rican example of a Migrations Division within the Ministry of Employment.

\section{Cultural Exchange, Proximity and Distance}

1 For further reference to Dutch cultural policies with regard to Suriname, the Netherlands Antilles and Aruba, see Oostindie \& Klinkers 2001, I:161-5 (1940-1954); II:210-23 (1954-1975); III:318-31(1975-2000).

2 De Bruijne \& Schalkwijk 1994:232-3.

3 For a detailed analysis of colonial and post-colonial language policies in Curaçao, see Smeulders 1987 and van Putte 1999. For Suriname, Gobardhan 2001. For language, national identity and migration in both the Antilles and Suriname, see Oostindie 1996 and 2004. For a comparative perspective on Dutch colonial language policies, see Groeneboer 1997.

4 E. de Kort (KVP) HTK, 20-12-1946, p. 1065.

5 HEK, 11-2-1969, p. 1581.

6 Van Krimpen (PvdA; HEK, 18-6-1980, pp. 1006-7). Remarkably, one year previously van Krimpen had also warned about the danger of the Antilles growing addicted to development aid, which was making independence less and less realistic.

7 Hirsch Ballin(HTK, 30-10-1991, p. 899). 
8 Explanatory memorandum, National budget for 1993; TK, 1992-1993, $22800 \mathrm{IV}$, nr. 2, p. 14, also pp. 15-7. Memorandum 'Samenwerken op het terrein van Onderwijs - Nederlandse Antillen, Aruba en Nederland', presented to the Dutch parliament on 22-4-1993.

9 ANP-bericht, 17-9-1997 (KnipselkrantKabNA, nr. 3225, p.6).

10 Sticusa Jaarboek 1950, p. ix.

11 National budget for 1956 , Chapter XIII, interim report, p.3.

12 Installation speech Queen Juliana, The Hague, 2-2-1961 (Adviesraad 1986:7).

13 Cola Debrot, Amigoe di Curaçao, 30-8-1977. Frank Martinus Arion, Vrij Nederland, 5-11-1988. Wijnie Jabaaij (нтк, 19-1-1983, p.1651).

14 Letter Minister A.P.J.M.M. van der Stee to the chairman of the House of Commons, 18-12-1979.

15 These observations are mainly based on a discussion with Richard and Sally Price, anthropologists living in Martinique (Leiden, 1-4-2003).

16 Quotation taken from Price 1998:182 (Price refers specifically to the Martiniquans; we presume this observation to apply to all Caribbean Dom citizens). On French Caribbean culture and its manifold paradoxes, see Burton 1994, Price 1998, Daniel 2001, Hintjens 2001, Miles 2001, and Réno 2001; see also Chapter 2 of this book.

17 Quoted in Oostindie 1996:225.

18 Alongside its tributes to local Creoles and dialects, the 1993 report of the West India Commission, Time for Action, equally emphasised the imperative of continuing and even expanding the use of English in the curriculum of Commonwealth Caribbean education (West India Commission 1993:269-306).

19 See Duany 1996, Kerkhof 2001 and Ortega 2001, including the literature cited therein.

20 The language situation in Aruba is quite comparable to the one prevailing in Curaçao, with Papiamentu being the vernacular of all classes. Command of the Dutch language is probably only slightly better on Aruba. Yet Aruban politicians have been eager - whether from conviction, political expediency, or both - to emphasise their full support for Dutch as the first language of education. Compare Henny Eman's words, expressed while still serving as prime minister: 'We have chosen very consciously in favour of a bond with the Netherlands and of the maintenance of the Dutch as vernacular. Our instructors should speak Dutch properly. The best possible education in Dutch.' Interview J.H.A. Eman, 17-10-1997 (KITLV, Collectie Oostindie \& Klinkers).

\section{Epilogue}

1 This has been outlined in the first three chapters of this book.

2 Aldrich \& Connell 1998:238-9.

3 From 1980 to 1987 and again briefly in 1990, Suriname was ruled by a military regime under Desi Bouterse. For some general observations on the economic and demographic development of the Republic, see Chapters 8 and 9. English-language studies of the post-independence development of Suriname include Chin \& Buddingh' 1987, Dew 1994, and Hoefte \& Meel 2001.

4 Technically, of course, 'colonies' is not a fitting categorisation of the non-sover- 
eign Caribbean if one takes into account that the 'colonised' populations have been given the opportunity to gain full independence, yet have not taken this opportunity. On the other hand, the usage of the term 'colony' may be justified by the fact that the metropolis in the end is the decisive factor in the governance of these territories. Thus, not only politicians critical of this status, but equally political scientists make use of the concept, e.g. Aldrich \& Connell (1998) and Ramos \& Rivera (2001).

5 Cf. Chapters 1-3 and Oostindie \& Verton 1998a:44-6.

6 Oostindie \& Verton 1998b; for an English-language summing-up, see Oostindie \& Verton 1998a. Representative survey, $\mathrm{n}=\mathbf{2 5 1 8}$.

7 Presently relations are being reconsidered. The proposed revisions will, however, not fundamentally change the character of the relationship. See Chapter 2.

8 For a more elaborate discussion of transfers, see Chapter 8, particularly the section 'A Comparative Perspective'. The European contribution amounts to $15-20 \%$ of the total transfers to the Dom.

9 Compare Ramos \& Rivera 2001a:6-8 and 2001b. Incidentally, while the European Union is insisting on complete liberalisation of economic relations within the Union, its own agrarian policies are still characterised by protectionist traditions, much to the detriment of outside producers.

10 Oostindie \& Verton 1998a:58.

11 He made this statement in 1904; quoted in Kuitenbrouwer 2001:77. With the choice for this quotation it is of course not suggested that the Antillean and Aruban administrations should be described as 'corrupt'.

12 Over the past years, various (mainly right-wing) Dutch politicians as well as some Dutch scholars (e.g., van den Doel \& Emmer 2000, Verton 2002) have affirmed that the real choice for the Antilles and Aruba is between a departmental status or sovereignty. Most specialists have at the same time argued that according to the word and certainly the spirit of the Charter, this can only be accomplished by a tripartite consensus. Recently, however, the case has been made that if such consensus cannot be accomplished, the Netherlands itself should, and lawfully can, secede from the Charter (not the Kingdom). Jessurun d'Oliveira (2003) maintains that there is a juridical basis for such a move, which incidentally was also propagated in the early 1970 s by Dutch politicians frustrated at Caribbean opposition against independence. The idea that full independence of the Antilles and Aruba is after all the only acceptable outcome of the decolonisation process also seems to be making a comeback, inspired no doubt by frustration over the absence of constructive debate over changes in the present Kingdom relations; e.g. Boersema 1999.

13 This position of the two 'purple' coalitions as well as the following centre-right one reflected the failure of the 'Toekomstconferentie' of 1993 which did aim to renew the Charter (see Chapter 7).

14 In the event of the need for a revision of the Charter, this would also imply Aruban approval, thus a dance of three.

15 The first Balkenende coalition squarely refused to even consider a further fragmentation of the Antilles. See the responsible Minister Remkes in parliament in December 2002 (NRC Handelsblad, 12-12-2002). Yet a few months later he was more open to discussion of this issue (www.amigoe.com, 1-3-2003), a position by now apparently acceptable to more Dutch policy makers.

16 In fact, a recent estimate puts this figure at over 60 per cent (Paul Schnabel, NRC Handelsblad, 23-2-2003). 
17 These observations are based on our many discussions with protagonists on all sides during the past years (see list of interviews in Oostindie \& Klinkers 2001, III:611-2). More recently they also reflect the exchanges we had with the last Dutch State Secretary responsible for Antillean and Aruban affairs Gijs de Vries and the Plenipotentiary Minister for the Netherlands Antilles Carel de Haseth. While the commitment of both protagonists to these matters is indisputable and while their appreciation for one another is evident, their points of view on many issues remain remarkably at odds. Two examples of Caribbean complaints about presumed Dutch hypocrisy apply to the drugs trade and European economic policies. Caribbean spokesmen often point out that The Hague, and certainly the Dutch media, complain time and again about the Antillean and Aruban role in international narcotrafficking, while the metropolis itself has a rather liberal policy towards drugs use and in fact is a major consumer of drugs channelled through the islands from Latin America. As for economic policies, the Dutch request of complete liberalisation of the Caribbean economies is often contrasted with persistent remnants of protectionism within the European Union.

18 Compare the news report in the Antillean newspaper Amigoe of the early-2003 talks between Antillean Prime Minister Etienne Ys and Dutch Minster of the Interior and Kingdom Affairs Johan Remkes. They concluded that because the Charter will achieve its $50^{\text {th }}$ jubilee in 2004, 'a study will ascertain as to whether it is necessary to evaluate the Charter and how such an evaluation should be organised' (www.amigoe.com, 1-3-2004). Preparations are now being made to install a trilateral commission which will study relations within the Kingdom and between (individual countries of) the Kingdom and Europe. Previously The Hague refused to engage in such deliberations. This change of attitude apparently reflects a growing conviction that a change of the Charter is both desirable and feasible. In the necessary negotiating process, The Hague will no doubt request an enhancement of Kingdom instruments in the fields of good governance and social and economic development. The claims of the individual islands of the Antilles might well boil down to a complete disintegration of the five-island state, and a definition of new bilateral relations of some sort with the Netherlands. Aruba, already in many ways having the best of possible worlds, will probably be reticent to go along with any change that might affect its own status.

The 'Regeerakkoord' of the second Balkenende administration (May 2003) includes a cautious statement on the need to 'reconsider' the Kingdom relations, immediately adding that the Charter will remain the foundation of these relations. The new government aims at the designation of the Netherlands Antilles and Aruba as ultraperipheral regions of the European Union. All government declarations are in the library of the Dutch Government Information Service (RVD) in The Hague.

19 Girvan 2001:9.

20 E.g. Duany 2000, Griffith 2000a and 200ob, Ramos \& Rivera 2001b, Serbin 1998, Tulchin \& Espach 2000.

21 Fernández 2000:267, 'Puerto Rico's situation is a colonial one. Whether it is by consent, agreement, accord, imposition, or whatever reason may be put forth each and every Puerto Rican should be aware that he (she) lives in a colony.'

22 Of the 210 million citizens in the Acs countries, seventeen per cent live in the Caribbean, 68 per cent live in the 'Group of 3' (Mexico, Colombia, Venezuela) and a further fifteen per cent live in Central America. The proportion of land area is 77 per cent for the G3, nine per cent for Central America and fourteen per cent for the 
Caribbean. Per capita incomes differ considerably. In 1991, on the eve of the establishment of the ACs, the average income in all ACs countries was $\$ 2,516$. Income in the non-sovereign Caribbean $(\$ 9,212)$ was far above the average. The figures for the other groups are: \$2,917 in the Group of 3 and \$2,777 in the CARICOM countries. The non-CARICOM Caribbean (\$956) and Central America (\$ 938) in contrast were well below the average (Serbin 1998:72, see also 6o-2, 75; Girvan 2001:8-9). This picture has not significantly changed since.

Remarkably, the reputed Jamaican scholar Norman Girvan, at the time of this writing Secretary-General of the Association of Caribbean States, wrote extremely cautiously of the prospect of further Caribbean integration and also remarked that 'It is by no means clear to this writer that all or most of these societies will survive as viable entities' (Girvan 2001:21). 


\section{Bibliography}

Koninklijk Instituut voor Taal-, Land-en Volkenkunde, Leiden (KITLV) Collectie Oostindie \& Klinkers

NationaalArchief, The Hague (NA)

Gs, Kab geheim

KGS

KMP, 1942-1969

$270 \quad$ MinKol, dir. SNA

MinKol Londen

MinKol, codetelegr.

Minutes council of ministers, 1940-1975

Van Schaik coll.

Ministry of Foreign Affairs, The Hague(BZ)

BZ, code 3, 1945-1954

Adviescommissie

2001 Nét loke falta; Ontbrekende schakels; Missing Links; Advies inzake de aanpak van de criminaliteitsproblematiek onder Antillianen in Nederland.

Adviescommissie Antilliaans Medeburgerschap in Nederland. Den Haag, s.n.

Adviesraad

198625 jaar Adviesraad voor Culturele Samenwerking tussen de landen van het Koninkrijk 1961-1986. Amsterdam: Adviesraad [compiled by M.D. Thijs] Albertini, Rudolf von

1982 Decolonization; The Administration and Future of the Colonies 1919-1960. New York/London: Africana Publishing Company [1966]

Aldrich, Robert

1996 Greater France; A History of French Overseas Expansion. London: Macmillan

Aldrich, Robert \& John Connell

1992 France's Overseas Frontier; Départements et Territoires d'Outre-Mer. Cambridge: Cambridge University Press

1998 The Last Colonies. Cambridge: Cambridge University Press 
Anselin, Alain

1995 'West Indians in France', in: Richard D.E. Burton \& Fred Réno (eds.), French and West Indian; Martinique, Guadeloupe and French Guiana Today, pp.112-8. London: Macmillan

Ansprenger, Franz

1989 The Dissolution of the Colonial Empires. London/New York: Routledge

Armstrong, H.W., R.J. de Kervenoael, X. Li \& R. Read

1998 'A Comparison of the Economic Performance of Different Microstates, and Between Micro-states and Larger Countries', in: World Development 26:639-56

Armstrong, H.W. \& R. Read

2000 'Comparing the Economic Performance of Dependent Territories and Sovereign Microstates', Economic Development and Cultural Change, pp. 285-306

Austin, Dennis G.

1980 'The Transfer of Power; Why and How', in: W.H. Morris-Jones \& G.

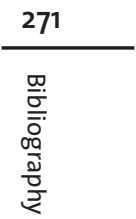

1986 Jagernath Lachmon; Een politieke biografie. Paramaribo: s.n.

Bernal, Richard L.

1995 'Influencing U.s. Policy Toward the Caribbean; A Post-Cold War Strategy', in: Anthony T. Bryan (ed.), The Caribbean; New Dynamics in Trade and Political Economy, pp. 209-30. New Brunswick/London: Transaction Publishers

Bevolkingsatlas

2003 Bevolkingsatlas van Nederland; Demografische ontwikkelingen van 1850 tot heden. Nederlands Interdisciplinair Demografisch Instituut. Rijswijk: Elmar

Blérald, Alain Philippe

1988 La question nationale en Guadeloupe et Martinique; Essai sur l'histoire politique. Paris: Éditions L'Harmattan

Boersema, Douwe A.A.

1999 'Het Statuut van 1954: ongezonde lectuur; Enkele opmerkingen over het schizofrene karakter van de staatkundige verhoudingen tussen Nederland en de Nederlandse Antillen en Aruba over de toekomst van het Statuut', in: Aruba Iuridica 5, pp. 7-36. Groningen: Universiteitsdrukkerij

Bootsma, Peter \& Willem Breedveld

1999 De verbeelding aan de macht; Het kabinet-Den Uyl 1973-1977. 's-Gravenhage: Sdu Uitgevers

Bossenbroek, Martin

1996 Holland op zijn breedst; Indië en Zuid-Afrika in de Nederlandse cultuur omstreeks 190o. Amsterdam: Bert Bakker 
Boxill, Ian

1993 Ideology and Caribbean Integration. Kingston: University of the WestIndies, Consortium Graduate School of Social Sciences

Breedveld, W. \& John Jansen van Galen

1996 Gaius - De onverstoorbare gang van W.F. de Gaay Fortman. Utrecht: Uitgeverij Scheffers

Breeveld, Hans

2000 Jopie Pengel 1916-1970; Leven en werk van een Surinaamse politicus. Schoorl: Conserve

Bruijne, G.A. de \& A. Schalkwijk

1994 'Kondreman en P'tata; Nederland als referentiekader voor Surinamers?', in: A.J. Brahin et al. (eds.), Suriname in het jaar 200o, pp. 225-41. Baarn: Bosch en Keuning

Bulmer-Thomas, Victor

2001 'The Wider Caribbean in the 2oth Century; A Long-Run Development Perspective', Integration \& Trade 15(5):5-56

Burac, Maurice

1995 'The French Antilles and the Wider Caribbean', in: Richard D.E. Burton \& Fred Réno (eds.), French and West Indian; Martinique, Guadeloupe and French Guiana Today, pp. 98-111. London: Macmillan

Burton, Richard D.E.

1995 'The French West Indies à l'heure de l'Europe; An Overview', in: Richard D.E. Burton \& Fred Réno (eds.), French and West Indian; Martinique, Guadeloupe and French Guiana Today, pp.1-19. London: Macmillan

Burton, Richard D.E. \& Fred Réno (eds.)

1995 French and West Indian; Martinique, Guadeloupe and French Guiana Today. London: Macmillan

Cabán, Pedro

1993 'Redefining Puerto Rico’s Political Status', in: Edwin Meléndez \& Edgardo Meléndez (eds.), Colonial Dilemma; Critical Perspectives on Contemporary Puerto Rico, pp.19-39. Boston: South End Press

Caraibisch Gebied

1998 Caraïbisch Gebied; Landenbeleidsdocument. 's-Gravenhage: Ministerie van Buitenlandse Zaken

Carrión, Arturo Morales

1963 'The Historical Roots and Political Significance of Puerto Rico', in: Curtis A. Wilgus (ed.), The Caribbean; British, Dutch, French, United States, pp. 139-69. Gainesville: University of Florida Press [1958]

Chin, Henk E. \& Hans Buddingh'

1987 Suriname; Politics, Economics and Society. London/New York: Frances Pinter

Commissie

1970 De meidagen van Curaçao; Het volledige en ongewijzigde Rapport dat de 
Commissie tot onderzoek van de achtergronden en oorzaken van de onlusten welke op 30 mei 1969 op Curaçao hebben plaatsgehad, in mei 1970, bij de Antilliaanse regering indiende. Willemstad: Ruku

Connell, John

1994 'Britain's Caribbean Colonies; The End of the Era of Decolonisation?', Journal of Commonwealth and Comparative Politics 32(1):87-106

2001 'Eternal Empire: Britain's Caribbean Colonies in the Global Arena', in: Aarón Gamaliel Ramos \& Angel Israel Rivera (eds.), Island at the Crossroads; Politics in the Non-Independent Caribbean, pp. 115-35. Kingston: Ian Randle/Boulder: Lynne Rienner

Constant, Fred

2001 'The French Antilles in the 1990s: Between European Unification and Political Territorialisation', in: Aarón Gamaliel Ramos \& Angel Israel Rivera (eds.), Island at the Crossroads; Politics in the Non-Independent Caribbean, pp. 80-94. Kingston: Ian Randle/Boulder: Lynne Rienner

Conway, Dennis

2000 'The Importance of Migration for Caribbean Development', Global Development Studies 2:73-105

Crassweller, Robert D.

1972 The Caribbean Community; Changing Societies and us Policy. Westport: Praeger

Croese, Koen

1998 Interventie op afspraak; Nederlandse mariniers op Curaçao. Zutphen: Walburg Pers

1999 'De militaire bijstand', in: Gert Oostindie (ed.), Dromen en littekens; Dertig jaar na de Curaçaose revolte, 30 mei 1969, pp. 83-96. Amsterdam: Amsterdam University Press

Dam, Ferdinand van

1999 Omzien naar de Derde Wereld; Artikelen en discussies over het ontwikkelingsvraagstuk 1978-1998. 's-Gravenhage: Sdu Uitgevers

Daniel, Justin

2001 'The Construction of Dependency; Economy and Politics in the French Antilles', in: Aarón Gamaliel Ramos \& Angel Israel Rivera (eds.), Island at the Crossroads; Politics in the Non-Independent Caribbean, pp. 61-79. Kingston: Ian Randle/Boulder: Lynne Rienner

$D B P N$

1996- Documenten betreffende de buitenlandse politiek van Nederland 1919-1945,

A.F. Manning \& A.E. Kersten (eds.). 's-Gravenhage: Martinus Nijhoff

Debrot, N.

1953 'Politieke aspecten in het Caraïbische gebied', Nieuwe West-Indische Gids 34:160-72 
Dew, Edward

1978 The Difficult Flowering of Surinam; Ethnicity and Politics in a Plural Society. 's-Gravenhage: Martinus Nijhoff

1994 The Trouble in Suriname, 1975-1993. Westport: Praeger

Díaz, José O.

1995 'Puerto Rico, the United States, and the 1993 Referendum on Political Status', Latin American Research Review 30(1):203-11

Dierikx, M.L.J. et al.

2002 Nederlandse ontwikkelingssamenwerking; Bronnenuitgave; Deel 1, 19451963. Den Haag: Sdu Uitgevers

Doel, H.W. van den

2000 Afscheid van Indië; De val van het Nederlandse imperium in Azië. Amsterdam: Prometheus

Doel, H.W. van den \& P.C. Emmer

2000 'De dekolonisatie van Nederland', Internationale Spectator 54(7/8): 339-46

Domingo, Janette $O$.

1991 'Security and Self-Determination in the U.s. Virgin Islands', in: L. Griffith (ed.), Strategy and Security in the Caribbean, pp. 169-97. New York: Praeger

Domínguez, Jorge I.

1993 'The Caribbean Question; Why has Liberal Democracy (Surprisingly) Flourished?’, in: Jorge I. Domínguez, Robert A. Pastor \& R. Delisle Worrell (eds.), Democracy in the Caribbean; Political, Economic, and Social Perspectives, pp. 1-25. Baltimore: Johns Hopkins University Press

Drower, George

1992 Britain's Dependent Territories; A Fistful of Islands. Dartmouth: Aldershot Duany, Jorge

1996 'Imagining the Puerto Rican Nation: Recent Works on Cultural Identity', Latin American Research Review 31:248-67

2000 'The Fear of Illegal Aliens; Caribbean Migration as a National and Regional Security Threat', in: Joseph S. Tulchin \& Ralph H. Espach (eds.), Security in the Caribbean; The Challenge of Regional Cooperation, pp. 97-117. Boulder, co: Lynne Rienner

Excessennota

1995 Nota betreffende het archiefonderzoek naar de gegevens omtrent excessen in Indonesië begaan door Nederlandse militairen in de periode 1940-1950. Ingeleid doorJan Bank. Den Haag: Sdu Uitgeverij

Fernandes Mendes, H.K.

1989 Onafhankelijkheid en parlementair stelsel in Suriname; Hoofdlijnen van een nieuw en democratisch staatsbestel. Zwolle: Tjeenk Willink

Fernández, Juan R.

[2000] 'Puerto Rico; The Evanescence of the Political Status Issue and the 
Need for a Major Social Project', Homines 20-22:263-80

Foreign and Commonwealth Office

1999 Partnership for Progress and Prosperity-Britain and the Overseas Territories. Presented to Parliament by the Secretary of State for Foreign and Commonwealth Affairs by Command of Her Majesty, March 1999

García Muñiz, Humberto

1991 'Decolonization, Demilitarization, and Denuclearization in the Caribbean', in: Ivelaw L. Griffith (ed.), Strategy and Security in the Caribbean, pp. 27-54. New York: Praeger

García-Passalacqua, Juan Manuel

1993 'The Role of the Puerto Rican People in the Caribbean', in: Jorge I. Domínguez, Robert A. Pastor \& R. Delisle Worrell (eds.), Democracy in the Caribbean; Political, Economic, and Social Perspectives, pp. 173-86. Baltimore: Johns Hopkins University Press

Gastmann, A.L.

1964 The Place of Surinam and the Netherlands Antilles in the Political and Constitutional Structure of the Kingdom of the Netherlands. Columbia: Columbia University, University Microfilms International

Gautier-Mayoral, Carmen

1994 'Puerto Rico; Problems of Democracy and Decolonization in the late Twentieth Century', in: Carlene J. Edie (ed.), Democracy in the Caribbean; Myths and Realities, pp.163-79. Westport: Praeger

Gemengde Commissie

1979 Aanzet tot een integraal beleidskader voor de Nederlandse Antillen in de jaren tachtig. Rapport uitgebracht aan de regeringen van de Nederlandse Antillen en Nederland over de economische, financiële, sociale en culturele ontwikkelingen in de Nederlandse Antillen op lange termijn door de Gemengde Commissie van Deskundigen, ingesteld bij Koninklijk Besluit d.d. 26 november 1976, 's-Gravenhage/Willemstad, juli 1979.'s-Gravenhage: Staatsuitgeverij

Giacalone, Rita

2001 'The Political Status of Curaçao at the End of the Twentieth Century', in: Aarón Gamaliel Ramos \& Angel Israel Rivera (eds.), Island at the Crossroads; Politics in the Non-Independent Caribbean, pp. 95-105. Kingston: Ian Randle/Boulder: Lynne Rienner

Girvan, Norman

2001 'Reinterpreting the Caribbean', in: Brian Meeks \& Folke Lindahl (eds.), New Caribbean Thought; A Reader, pp. 3-23. Kingston, Jamaica: The University of the West Indies Press

Gobardhan-Rambocus, Lila

2001 Onderwijs als sleutel tot maatschappelijke vooruitgang; Een taal-en onderwijsgeschiedenis van Suriname, 1651-1975. Zutphen: Walburg Pers

Gortzak, W.(ed.)

1978 De kleine stappen van het kabinet-Den Uyl; Gesprekken met PvdA-bewindslieden. Deventer: Kluwer 
Griffith, Ivelaw L.

2000a 'Drugs and the Emerging Security Agenda in the Caribbean', in: Joseph S. Tulchin \& Ralph H. Espach (eds.), Security in the Caribbean; The Challenge of Regional Cooperation, pp. 137-50. Boulder, co: Lynne Rienner

Griffith, Ivelaw L.(ed.)

2ooob The Political Economy of Drugs in the Caribbean. London: Macmillan/ New York: St. Martin's Press

Groeneboer, Kees

1997 Koloniale taalpolitiek in Oost en West; Nederlands-Indië, Suriname, Nederlandse Antillen en Aruba. Amsterdam: Amsterdam University Press

Grosfuegel, Ramón

1997 'Colonial Caribbean Migrations to France, The Netherlands, Great Britain and the United States', in: Lowell Fiet \& Janette Becerra (eds.), Caribe 2000; Definiciones, identidades y culturales regionales $y / 0$ nacionales, pp. 58-80. San Juan PR: Universidad de Puerto Rico

Haan, Edo

1998 Antilliaanse instituties; De economische ontwikkeling van de Nederlandse Antillen en Aruba, 1969-1995. PhD-thesis, Rijksuniversiteit Groningen

Heine, Jorge \& Juan M. García-Passalacqua

1993 'Political Economy and Foreign Policy in Puerto Rico', in: Anthony Payne \& Paul Sutton (eds.), Modern Caribbean Politics, pp. 198-211. Baltimore/London: Johns Hopkins University Press

Helsdingen, W.H. van

1957 Het Statuut voor het Koninkrijk der Nederlanden; Wordingsgeschiedenis, commentaar en praktijk.'s-Gravenhage: Staatsdrukkerij- en Uitgeversbedrijf

Hintjens, Helen M.

1991 'France in the Caribbean', in: Paul Sutton (ed.), Europe and the Caribbean, pp.37-69. London: Macmillan

1992 'France's Love Children?; The French Overseas Departments', in: Helen M. Hintjens \& Malyn D.D. Newitt (eds.), The Political Economy of Small Tropical Islands; The Importance of Being Small, pp. 64-75. Exeter: University of Exeter Press

1995 'Constitutional and Political Change in the French Caribbean', in: Richard D.E. Burton \& Fred Réno (eds.), French and West Indian; Martinique, Guadeloupe and French Guiana Today, pp. 20-33. London: Macmillan

2001 'What is Freedom? Competing Notions of Rights \& Responsibilities in the French Caribbean', Itinerario; European Journal of Overseas History 25(2):23-41

Hintjens, Helen M., John Loughlin \& Claude Olivesi

1995 'The Status of Maritime and Insular France; The ром-том and Corsica', in: John Loughlin \& Sonia Mazey (eds.), The End of the French 
Unitary State?; Ten Years of Regionalization in France (1982-1992), pp. 11031. London: Frank Cass \& Co

Hirsch Ballin, Ernst M.H.

2001 'The constitutional relationship between the Caribbean Overseas

Countries and Territories and their mother countries', in: Conference Report. The economic development of the Caribbean overseas countries and territories: the role of their European partners. The Hague, 20-21 June 2001, Ministerie van Binnenlandse Zaken en Koninkrijksrelaties

Hoefte, Rosemarijn

1999 'Internationale reacties op de revolte en het Nederlandse ingrijpen', in: Gert Oostindie (ed.), Dromen en littekens; Dertig jaar na de Curaçaose revolte, 30 mei 1969, pp. 147-62. Amsterdam: Amsterdam University Press

2001 'The Difficulty of Getting it Right: Dutch Policy in the Caribbean', Itinerario; European Journal of Overseas History 25(2):59-72

Hoefte, Rosemarijn \& Peter Meel (eds.)

2001 2oth Century Suriname; Continuities and Discontinuities in a New World Society. Kingston: Ian Randle/Leiden: KITLV Press

Hoefte, Rosemarijn \& Gert Oostindie

1991 'The Netherlands and the Dutch Caribbean; Dilemmas of Decolonisation', in Paul Sutton (ed.), Europe and the Caribbean, pp. 71-98. London: Macmillan

Hoetink, Harry

1999 'Flarden van een geschiedenis', in: Gert Oostindie(ed.), Dromen en littekens; Dertig jaar na de Curaçaose revolte, 30 mei 1969, pp.325-37. Amsterdam: Amsterdam University Press

Jansen van Galen, John

1995 Kapotte plantage; Suriname, een Hollandse erfenis. Amsterdam: Uitgeverij Balans

Jansen van Galen, John \& Bert Vuijsje

1985 Joop den Uyl:politiek als hartstocht; Een portret in twintig interviews. Weesp: Van Holkema en Warendorf

Jessurun d'Oliveira, H.U.

2003 'Nederlandse secessie uit het Koninkrijk. Oftewel: Fifty Ways to Leave your Lover(s)', in: J.L. de Reede \& J.H. Reestman (eds.), Op het snijvlak van recht en politiek; Opstellen aangeboden aan prof.mr. L. Prakke, pp.111-30. Deventer: Kluwer

Kasteel, Annemarie C.T.

1956 De staatkundige ontwikkeling der Nederlandse Antillen. 's-Gravenhage/ Bandung: Van Hoeve

Kerkhof, Erna

2000 Contested Belonging; Circular Migration and Puerto Rican Identity. S.l.: s.n. [Maastricht: Shaker] PhD-thesis, Universiteit Utrecht 
Klinkers, Inge A.J.

1999 Deweg naar het Statuut; Het Nederlandse dekolonisatiebeleid in de Caraïben (1940-1954) in vergelijkend perspectief. PhD-thesis, Universiteit Utrecht Knight, Franklin W.

1990 Caribbean; The Genesis of a Fragmented Nationalism. [2nd Edition.] New York [etc.]: Oxford University Press

1993 'The Societies of the Caribbean since Independence', in: Jorge I. Domínguez, Robert A. Pastor \& R. Delisle Worrell (eds.), Democracy in the Caribbean; Political, Economic, and Social Perspectives, pp. 29-41. Baltimore: Johns Hopkins University Press

Koninkrijkscommissie

1974 Rapport ter voorbereiding van de onafhankelijkheid van Suriname. Koninkrijkscommissie ter voorbereiding van de alternatieven voor de huidige staatkundige verhouding tussen Nederland, Suriname en de Nederlandse Antillen.’s-Gravenhage: Staatsuitgeverij

1980 Rapport van de Koninkrijkswerkgroep; Naar nieuwe vormen van samenwerking.'s-Gravenhage: Staatsuitgeverij

Kuitenbrouwer, Maarten

2001 Tussen oriëntalisme en wetenschap; Het Koninklijk Instituut voor Taal-, Land-en Volkenkunde in historisch verband, 1851-2001. Leiden: KITLV Uitgeverij

Lampe, Armando

2001 'The Recolonisation of Aruba', in: Aarón Gamaliel Ramos \& Angel Israel Rivera (eds.), Island at the Crossroads; Politics in the Non-Independent Caribbean, pp. 106-14. Kingston: Ian Randle/Boulder: Lynne Rienner

Ledgister, F.S.J.

1998 Class Alliances and the Liberal Authoritarian State; The Roots of Post-Colonial Democracy in Jamaica, Trinidad and Tobago, and Surinam. Trenton, N.J. Africa World Press

Lewis, Gordon K.

1963 Puerto Rico; Freedom and Power in the Caribbean. New York: M.R. Press

1985 'The Contemporary Caribbean; A General Overview', in: Sidney W. Mintz \& Sally Price (eds.), Caribbean Contours, pp. 219-5o. Baltimore/ London: Johns Hopkins University Press

Maingot, Anthony P.

1994 The United States and the Caribbean. London: Macmillan

Meel, Peter

1998 'De Ronde Tafel Conferentie van 1961; Nederland en Suriname in het spanningsveld van vrijheid, gelijkwaardigheid en gebondenheid', Tijdschrift voor Geschiedenis 111(3):411-32

1999 Tussen autonomie en onafhankelijkheid; Nederlands-Surinaamse betrekkingen 1954-1961. Leiden: KITLV Uitgeverij 
Miles, William

2001 'Fifty Years of Assimilation; Assessing France's Experience of Caribbean Decolonisation Through Adminstrative Reform', in: Aarón Gamaliel Ramos \& Angel Israel Rivera (eds.), Island at the Crossroads; Politics in the Non-Independent Caribbean, pp. 45-6o. Kingston: Ian Randle/Boulder: Lynne Rienner

Mitrasing, F.E.M.

1959 Tien jaar Suriname; Van afhankelijkheid tot gelijkgerechtigheid; Bïdrage tot de kennis van de staatkundige ontwikkeling van Suriname 1945-1955. Leiden: Luctor et Emergo

Morris, Nancy

1995 Puerto Rico; Culture, Politics and Identity. London: Praeger

Naipaul, V.S.

1982 The Middle Passage; Impressions of Five Societies - British, French and Dutch - in the West Indies and South America. Harmondsworth: Penguin [1962]

NAR

1978 Nationale Advies Raad voor Ontwikkelingssamenwerking; Advies Nederlandse Antillen, nr. 59.'s-Gravenhage: NAR

Netherlands News

1942 Netherlands News. London: [Voorlichtingsdienst Regering in Ballingschap]

Nicholls, Shelton

2001 'Panel Data Modelling of Long-Run per Capita Growth Rates in the Caribbean; An Empirical Note', Integration \& Trade 15(5):57-82

Ontwikkeling in vertrouwen

1997 Ontwikkeling in vertrouwen; Naar een Antilliaanse Ontwikkelingsfinancieringsmaatschappij. Eindrapport van de Commissie Financieringsmodaliteiten.'s-Gravenhage: s.n.

Ooft, Benny Ch. \& H. Hendriks

1976 Het laatste hoofdstuk (een analyties verslag van het overleg en de ontwikkelingen rond de onafhankelijkheid van Suriname in 1974 en 1975). Utrecht: Stichting Landelijke Federatie van Welzijnsstichtingen voor Surinamers

Oostindie, Gert J.

1988 'Caribbean Migration to the Netherlands; A Journey to Disappointment?’, in: Malcolm Cross \& Han Entzinger (eds.), Lost Illusions; Caribbean Minorities in Britain and the Netherlands, pp. 54-72. London: Routledge

1992 'The Dutch Caribbean in the 1990s: Decolonization, Recolonization?', Caribbean Affairs 5(1):103-19

1996 'Ethnicity, Nationalism, and the Exodus: The Dutch Caribbean Predicament', in: Gert Oostindie (ed.), Ethnicity in the Caribbean, pp. 206-31. London: Macmillan

1997 Het paradijs overzee; De 'Nederlandse' Caraïben en Nederland. Amsterdam: Bert Bakker 
2004 Paradise Overseas; The Dutch Caribbean: Colonialism and its Transatlantic Legacies. London: Macmillan

Oostindie, Gert J.(ed.)

1999a Curaçao 30 mei 1969; Verhalen over de revolte. Amsterdam: Amsterdam University Press

1999b Dromen en littekens; Dertig jaar na de Curaçaose revolte, 30 mei 1969. Amsterdam: Amsterdam University Press

1999c 'Woedend vuur; “Trinta di mei”, dertig jaar later', in: Gert Oostindie (ed.), Dromen en littekens; Dertig jaar na de Curaçaose revolte, 30 mei 1969, pp. 9-39. Amsterdam: Amsterdam University Press

Oostindie, Gert J. \& Inge A.J. Klinkers

2001 Knellende Koninkrijksbanden; Het Nederlandse dekolonisatiebeleid in de Caraïben, 1940-2000. 3 volumes. Amsterdam: Amsterdam University Press

Oostindie, Gert J. \& Peter C. Verton

1998a 'Ki sorto di Reino?/What Kind of Kingdom? Antillean and Aruban Views and Expectations of the Kingdom of the Netherlands', New West Indian Guide 72:43-75

1998b Ki sorto di Reino?/What Kind of Kingdom? Visies en verwachtingen van Antillianen en Arubanen omtrent het Koninkrijk. 's-Gravenhage: Sdu Uitgevers

Opeigen benen

1997 Op eigen benen; Eindrapport van de Adviescommissie Samenwerking ArubaNederland. Oranjestad,'s-Gravenhage: s.n.

Alegría Ortega, Idsa E.

2001 'Culture and Politics and Self-Determination in Puerto Rico', in: Aarón Gamaliel Ramos \& Angel Israel Rivera (eds.), Island at the Crossroads; Politics in the Non-Independent Caribbean, pp. 28-44. Kingston: Ian Randle/Boulder: Lynne Rienner

Parry, J.H., P.M. Sherlock \& A.P. Maingot

1987 A Short History of the West Indies. New York: St. Martin’s Press

Paula, A.F.

1988 'Hoofdmomenten uit de staatkundige ontwikkeling van de Nederlandse Antillen, 1865-1986', in: C.M. Gruning, J.L. Martina \& R. Winkel (eds.), 50 Jaar Staten van de Nederlandse Antillen; 1938 - 5 april 1988, pp.19-107. Willemstad: Staten van de Nederlandse Antillen

Payne, Anthony

1991 'Britain and the Caribbean', in: Paul Sutton (ed.), Europe and the Caribbean, pp.13-36. London: Macmillan

Payne, Anthony \& Paul Sutton

1993 'Introduction; The Contours of Modern Caribbean Politics', in: Anthony Payne \& Paul Sutton (eds.), Modern Caribbean Politics, pp. 1-27. Baltimore/London: Johns Hopkins University Press

2001 Charting Caribbean Development.London: Macmillan 
Phillips, Dion E.

1991 'The U.s. "Special Relationship” with the Virgin Islands; Definition and Prospects for Independence', in: Joseph Lisowski (ed.), The Social Structure of a Region, pp. 1-17. New Brunswick etc.: Transactions Publishers

Price, Richard

1998 The Convict and the Colonel. Boston: Beacon Press

Proudfoot, $\mathrm{M}$.

1954 Britain and the United States of America in the Caribbean. London: Faber \& Faber

Putte, Florimon van

1999 Dede pikiña ku su bisiña; Papiamentu - Nederlands en de onverwerkt verleden tijd.Zutphen: Walburg Pers

Ramos, Aarón Gamaliel \& Angel Israel Rivera

2001a 'Puerto Rico: Regional Transformations and Political Change', in: Aarón Gamaliel Ramos \& Angel Israel Rivera(eds.), Island at the Crossroads; Politics in the Non-Independent Caribbean, pp. 1-27. Kingston: Ian Randle/Boulder: Lynne Rienner

Ramos, Aarón Gamaliel \& Angel Israel Rivera (eds.)

$2001 \mathrm{~b}$ Island at the Crossroads; Politics in the Non-Independent Caribbean. Kingston: Ian Randle/Boulder: Lynne Rienner

Ramsoedh, Hans

1990 Suriname 1933-1944; Koloniale politiek en beleid onder Gouverneur Kielstra. PhD-thesis, Rijksuniversiteit Utrecht

Réno, Fred

2001 'Re-Sourcing Dependency; Decolonisation and Post-colonialism in French Overseas Departments', Itinerario; European Journal of Overseas History 25(2):9-22

Richardson, Bonham C.

1989 'Caribbean Migrations, 1838-1985', in: Franklin W. Knight \& Colin A. Palmer (eds.), The Modern Caribbean, pp. 203-28. Chapel Hill: University of North Carolina Press

Rodríguez-Beruff, Jorge

1996 'Strategic Military Interests and Puerto Rican Self-determination', in: Jorge Rodríguez-Beruff \& Humberto García Muñiz (eds.), Security Problems and Policies in the Post-Cold War Caribbean, pp. 155-77. London/New York: MacMillan Press/St. Martin’s Press RTC 1981

Stenografisch verslag van de eerste zitting, gehouden van 16 tot en met $25 \mathrm{fe}$ bruari 1981 te's-Gravenhage.'s-Gravenhage: Staatsuitgeverij RTC 1983

Stenografisch verslag van de conferentie, gehouden van maandag 7 tot en met zaterdag 12 maart 1983 in de Rolzaal te 's-Gravenhage. 's-Gravenhage: Staatsuitgeverij 
Schuld of toekomst

1996 Schuld of toekomst; Rapport van de tripartiete commissie Schuldenproblematiek Nederlandse Antillen en Aruba. s.l.: s.n.

Schuster, John

1999 Poortwachters over immigranten; Een vergelijking van Engelse en Nederlandse immigratievertogen 1945-1980. Amsterdam: Het Spinhuis

Sedney, Jules

1997 De toekomst van ons verleden; Democratie, etniciteit en politieke machtsvorming in Suriname. Paramaribo: Vaco

Sedoc-Dahlberg, Betty (ed.)

1990 The Dutch Caribbean; Prospects for Democracy. New York: Gordon and Breach

Serbin, Andrés

1998 Sunset over the Islands; The Caribbean in an Age of Global and Regional Challenges. London: Macmillan

Smeulders, Toos Filomeen

1987 Papiamentu in het onderwijs; Veranderingen in beeld en betekenis van de volkstaal op Curaçao. PhD-thesis, Rijksuniversiteit Utrecht

Sticusa Jaarboeken

1950-'54 Sticusa Jaarboeken.Amsterdam: Sticusa

Sutton, Paul

1991 'Politics in the Commonwealth Caribbean; The Post-Colonial Experience', European Review of Latin American and Caribbean Studies 51(12): 51-66

1996 'Britain and the Commonwealth', in: Jorge Rodríguez Beruff \& Humberto García Muñiz (eds.), Security Problems and Policies in the Post-Cold War Caribbean, pp. 62-80. London: Macmillan/New York: St. Martin's Press

Thorndike, Tony

1991 'The British Caribbean Dependencies; Prospects and Possibilities', in: Michel L. Martin \& Alain Yacou (eds.), Études Caraibéennes: Société et Politique, pp. 275-99. Toulouse: Presses de l'Institut d'Études Politiques

Toekomst in samenwerking

1999 Toekomst in samenwerking; Nederland, Nederlandse Antillen en Aruba. 's-Gravenhage: Directoraat-generaal Constitutionele Zaken en Koninkrijksrelaties, Directie Koninkrijksrelaties, Ministerie van Binnenlandse Zaken en Koninkrijksrelaties

Trías Monge, José

1997 Puerto Rico; The Trials of the Oldest Colony in the World. New Haven: Yale University Press

Tulchin, Joseph S. \& Ralph H. Espach(eds.)

2000 Security in the Caribbean; The Challenge of Regional Cooperation. Boulder, co: Lynne Rienner 
Unck, Maurice

2001 'De Franse situatie; De Franse relatie met haar overzeese gebiedsdelen', in: Conferentiebundel. De Economische ontwikkeling van de Caribische landen en gebieden overzee (lgo): de rol van de moederlanden. Den Haag, 2021 June 2001, Ministerie van Binnenlandse Zaken en Koninkrijksrelaties

Vries, Gijs de

2002a 'De aardigste politicus van het Koninkrijk', in: Jaime M. Saleh et al., Het premierschap van Miguel Pourier, pp. 9-15. Nederland/Curaçao: Uitgeverij ICS

2002b 'Respect binnen het Koninkrijk', in: Nancy S. van de Wal \& Valdemar F. Marcha (eds.), Jaime Saleh: excellerende excellentie; Liber Amicorum, pp. 163-6. Amsterdam: swP

Velez, Diana

2000 'Redefining Puerto Rico's Commonwealth Status', sEcolas Annals 32:132-42

Verton, Peter

2002 'One man one vote; Vijftig jaar politiek en bestuur te Curaçao', Tijdschrift voorAntilliaans Recht-Justitiae (1):34-57

Wells, Henry

1955 'Constitutional Development in Puerto Rico', in: Developments Towards Self-Government in the Caribbean. A Symposium held under the auspices of the Netherlands Universities Foundation for International Cooperation at The Hague, September 1954, pp. 73-82

Wessels, Marius

1999a 'Logboek van een revolte van vuur; De gebeurtenissen tussen 1 mei en 5 juni 1969', in: Gert Oostindie (ed.), Dromen en littekens; Dertigjaar na de Curaçaose revolte, 30 mei 1969, pp. 41-81. Amsterdam: Amsterdam University Press

1999b 'Het rapport van de Commissie 30 mei 1969 en latere studies', in: Gert Oostindie (ed.), Dromen en littekens; Dertig jaar na de Curaçaose revolte, 30 mei 1969, pp. 177-210. Amsterdam: Amsterdam University Press

West India Commission

1993 Time for Action. Report of the West India Commission. Kingston: The Press - University of the West Indies

Willems, Wim

2003 'No Sheltering Sky: Migrant Identities of Dutch Nationals from Indonesia', in Andrea L. Smith (ed.), Europe's Invisible Migrants, pp. 336o. Amsterdam: Amsterdam University Press 


\section{Index of Names}

Adam, B.H. 183

Adhin, J.H. 113, 188, 234

Aerssen van Sommelsdijck, C. van 58

Agt, A.A.M. van 126, 235, 264

Amery, S. 235

Arron, H.A.E. 102, 104-7, 109-13, 115-6, 161-2, 184-5, 188, 211

Bakker, J.A. 100-1, 115-6, 160, 204

Balkenende, J.P. 119, 152, 163-4, 232, 267

Bean, M.T.J. 110

Beatrix, Queen 13,72, 171, 231

Beaujon,J.R.L. 116

Beel, L.J.M. 181, 208

Biesheuvel, B.W. 101-2, 182-3, 257, 261

Biswamitre, C.R. 218

Blair, T.C.L. 25

Bolkestein, F. 142

Bouterse, D.D. 188, 266

Boxtel, R.H.L.M. van 192

Brons, J.C. 76

Bruma, E.J. 95, 185

Buiskool, J.A.E. 81

Bulmer-Thomas, V. 259

Burton, R.D.E. 241

Bush, G.H.W. 50

Capriles, L. 261

Carter, J. 249

Castro, F. 48, 216

Césaire, A. 37, 196, 213, 215, 241, 243

Churchill, W.S. 32, 44, 66

Colijn, H. 60

Compton, J. 213

Constant, F. 40

Cook, R. 25

Cramwinckel, M.N. 234

Creech Jones, A. 236

Croes, A.G.(Mito) 130, 137-8, 141, 234

Croes, G.F. (Betico) 122-4, 126-30

Currie, A. 84
Dam, F. van 115

Debrot, N. (Cola) 88, 211

Derby, F. 111

Dijck, P. van 234

Doel, H.W. van den 267

Drees, W. 71, 77, 80-2, 84, 181

Eman, C.A. 'Shon A' 121

Eman, J.H.A.jr 117, 121, 125-6, 128-30, 141-2, 148, 266

Eman, J.H.A.sr 121

Emanuels, S.D. 93

Emmer, P.C. 267

Emmerij, L.J. 257

Evertsz,J.M.G. 116-7,122-3

Ferrier,J.H.E. 92, 113

Fonteyn, A.J. 183

Ford, G. 50

Fortuyn, P. 118, 257

Franssen, H.M. 117

Gaay Fortman, W.F. de 104, 107, 113, $115-6,123,160,167$

Gaulle, Ch. de 32, 35

Gerbrandy, P.S. 65-6

Girvan, N. 269

Götzen, L. 158

Gomez, M.F. da Costa 81

Gruijters, H. 264

Guerra Mondragón, M. 246

Haan, E. 261

Haseth, C.P. de 150, 193, 234, 257, 268

Hendriks, G. 184

Hernández Colon, R. 50

Hindori, G.D. 109

Hintjens, H.M. 241

Hirsch Ballin, E.M.H. 131-4, 137, 139-40, $146,148,168,205-6,234,238$

Ho Chi Minh 242 
Hoetink, H. 234

Isa, R.J. 116

Jabaaij, W. 211

Jagan, C. 236

Jessurun d'Oliveira, H.U. 267

Jonckheer, E. 84, 94-5, 100

Jong, P.J.S. de 182

Jonkman, J.A. 70, 73, 77, 208

Jospin, L. 39, 243

Joubert, E. L. 135

Juliana, Queen 13, 84, 88, 209

Karamat Ali, M.A. 158

Kernkamp, W.J.A. 82-3

Klaasesz, J. 79

Klinkers, I. 11

Knight, F.W. 234

Kok, W. 118, 138, 140-2, 152, 178, 192, 235

Kom, A. de 215

Koning, J. de 127, 130-1, 139, 168, 211, 231

Kort, E. de 204

Korthals, H.A. 94-5

Krimpen, Ch. van 205, 265

Kroon, C.D. 98, 101

Lachmon, J. 97,102,104, 109-13, 188

Lardinois, P.J. 101-2

Leeuwen, W.C.J. van 219

Leito, B.M. 100, 116

Lennep, E. van 261

Lewis, G.K. 52

Liberia-Peters, M.P. 134-5, 139

Lier, Th. van 101

Lise, C. 38-9, 41, 244

Logemann, J.H.A. 70-1, 73-5, 208, 251

Lubbers, R.F.M. 115-6, 118, 127-8, 131-3, 136-9, 151

MacLeod, I. 21

Maingot, A.P. 234

Major, J. 24

Martí, J. 16

Martina, D.F. 126-7

Martinus Arion, F. 211

Máxima, Princess 234

Mendes de Gouveia, E.J.M. 136

Merckelbach, H.P.J.M. 128, 130
Miles, W. 40

Mitterand, F. 38, 243-4

Mok, M.R. 183

Mook, H.J. van 67, 70-1, 73

Moyne, Lord 19

Mungra, L. 110

Muñoz Marín, L. 48, 246, 249

Nicholls, S. 259

Nooitmeer, R. B.R. 110

Nordholt, E. 191

Oduber, N.O. 128, 130, 148

Ooft, C.D. 112

Palm, F.A. 168

Parry, J.H. 234

Pengel, J.A. 93, 95-8, 253

285

Peper, A. 257

Pétain, H.P. 32

Peters, L.A.H. 80-1

Petronia, E. O. 100-1

Pourier, M.A. 129, 134-5, 149-50, 172, 229

Price, R. 40, 234

Pronk, J.P. 103-5, 113-6, 16o-2, 188, 254, 264

Quay, J.E.de 94,182

Ramos, A.G. 234

Reagan, R. 50, 249

Remkes, J.W. 267-8

Richardson, R.A. 137

Rivera, A.I. 234

Römer, S. 135, 137, 139

Roosevelt, F.D. 32, 44, 46, 66-7, 74, 245

Rosselló, P. 50

Rowlands, T. 238

Ruiter, J. de 141-2

Saleh, J.M. 150

Schaik,J.R.H. van 79

Sedney, J. 97, 100-1, 112-3

Sherlock, P.M. 234

Snouck Hurgronje, Chr. 228

Soemita, I. 112

Spoor, S.H. 71

Stanley, O. 20, 236 
Stee, A.P.J.M.M. van der 115-6, 124-6, 167-8, 205, 211

Struycken, A.A.M. 79-80

Suharto 72

Sukarno 65, 70-2

Tamaya, M. 38-9, 244

Thatcher, M. 24, 194

Thomson, G. 237

Tilburg,J. van 93, 181

Truman, H.S. 246

Uyl, J.M. den 13-4, 102-4, 106-11,113-8, $126,159-62,165,182-6,235$

Velázquez, N. 174

Venetiaan, R.R. 211

286

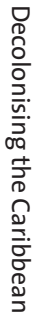

Voorhoeve, J.J.C. 140-1, 146, 148, 151, 168-9, 191-2, 206-7

Vries, G.M.de 141, 146, 148, 150-1, 168-70, 192, 206-7, 212, 234, 258, 268

Vries, K.G. de 151, 257

Wathey, A.C. 134

Wawoe, G.R. 257, 261

Welter, Ch.J.I.M. 66

Wijntuin, E.L.A. 110, 112-3, 188

Wilhelmina, Queen 13, 65-8, 73, 75-6, 84,86

Willem I, King 58

Willem-Alexander, Crown Prince 234

Williams, E.E. 122

Wilson, H. 29

Wilson, W. 44

Young, Baroness 24

Ys, E. 149, 151, 268 


\section{Index of Geographical Names}

Africa 18-9, 27, 29, 31-2, 34, 43, 57-9, 93, $153,173,177,194,216,232,236,240-2$, 258

Alaska 43, 248

Algeria 31-2, 35, 242

American Samoa 240, 245-6

Anguilla 21, 23, 26, 153-5, 174, 235-6, 238-9, 262

Antarctica 240

Antigua 21, 153-5, 235-6

Aruba 9-10, 13-5, 57-8, 6o, 63, 68, 77-8, $83,87,116-7,119-48,150-2,154-7$, 163-73, 176-80, 189-90, 192-3, 201, 203, 205-7, 212, 214, 219-25, 228-31, 239, 255, 259-61, 263-4, 266-8

Ascension 239

Asia 18-9, 27, 29, 34, 43, 45, 57, 59, 61, 76, 153, 173, 177, 194, 216, 232, 240, 242, 258

Australia 64, 180, 246

Azores 244

Bahamas 17, 23, 153-5, 235-7

Barbados 12, 17, 21-2, 153-5, 216, 235-6, 258, 262

Barbuda 21, 235-6

Belize 20,154-5, 235-6

Berbice 57, 235

Bermuda 17, 26, 221, 235-9

Bonaire 57-8, 132-3, 138, 201

Brazil 57, 74, 108, 178, 218-9, 252, 265

British Antarctic Territory 239

British Associated States 23-4, 237-8

British Dependent Territories 22-7, 195, 215, $237-9$

British Guiana, see Guyana

British Honduras, see Belize

British India 59, 70, 236, 246

British Indian Ocean Territory 23

British Overseas Territories 9, 11, 24-8, 156,173-6, 195-6, 213, 217, 220-2, 239,
261-3

British Virgin Islands 26, 154-5, 235-7, 239, 262

British West Indies 11, 17-20, 23, 26, 177, 194, 216, 234-6, 239-40, 264

Burma 236

Cambodia 241

Cameroon 241

Canada 64, 180, 194, 246

Canary Islands 244

Caribbean passim

Caroline Islands 245

Cayman Islands 26, 154-5, 175, 235-7, 239

Central America 43, 177, 233, 268-9

Channel Islands 239

China 25, 195, 222

collectivités territoriales 33, 241

Colombia 74, 144, 233, 268

Commonwealth 18-20, 23, 26-7, 29, 235-7, 253, 266

Comoros 242, 262

Congo 32

Cook Islands 23

Corsica 244

Cuba 9, 24, 43, 45, 48-9, 74, 153-5, 177, 198, 215-6, 220, 223, 232-3, 235, 245, 248, 259, 262

Curaçao 23, 57-8, 6o-2, 78, 83, 90, 96-9, 116, 119-27, 129, 133, 135-9, 142, 144, 148-9, 156-7, 16o, 164, 166, 170, 176-9, 182, 189, 191, 201-3, 205-6, 214, 218-9, 221, 228-9, 258-6o, 266

Cyprus 22

Demerara 57, 235

Denmark 45, 53, 59, 69, 261

départements d'outre-mer 9, 29-41,156, 172-3, 194, 196-8, 212-3, 215, 220-3, 234, 237, 239-44, 261, 265-7

Djibouti 242 
Dominica 17, 21, 154-5, 177, 198, 235-6, 262

Dominican Republic 9, 44, 153-5, 177 , 215, 220, 223, 233, 235, 245, 259

dominions 18, 26-7, 29, 235-6

Dutch East Indies, see Indonesia

Dutch West Indies 58-9, 61-2, 73-4, 76, 78, 86, 96, 101, 209

Eastern Samoa Islands 43

England, see United Kingdom

Essequibo 57, 235

etats associés 33, 241

Europe 9, 29, 35, 42-5, 57-8, 67, 89, 145, 152, 158, 176-7, 197-9, 209, 216, 232, 245

Falklands/Malvinas 24, 239, 262

Far Oer Islands 261

Federated States of Micronesia 245-6

France 9, 11, 17, 29-42, 45, 56, 58-9, 70, $86,108,144,172-5,177,196-9,212-3$, 215-6, 221-3, 239-45, 261-2

French Guiana 29-31, 34, 36, 80, 154-5, 173, 196, 233, 240, 243-4, 259, 262, 265

Germany 32, 44, 53, 65, 246

Gibraltar 239-40, 262

Great Britain, see United Kingdom

Greenland 261

Grenada 17, 21, 24, 154-5, 235-6, 238

Grenadines 21

Guadeloupe 29-31, 34, 36-40, 80, 154-5, 173, 194, 196, 240, 244, 259, 262, 265

Guam 43, 240, 245-6

Guyana 17, 20-2, 96-7, 108, 112, 144, 153-5, $177,216,223,233,235-6,238,258,262$

Guyane, see French Guiana

Haiti 9, 29, 41, 44, 153-5, 177, 198, 201, $215,220,223,233,235,245,258-9$, 262, 265

Hawaii 43, 213, 248

Hong Kong 25, 195, 199, 222

Iceland 22

Indochina 31, 34, 240, 242

Indonesia 10, 57-78, 84-6, 89, 91, 99, 113, $115,162,177-8,180,202,207-9,216-7$,
$228,242,251,260,263$

Isle of Man 239

Italy $44,134,144$

Jamaica 9, 17, 19-22, 153-5, 177, 194, 198, 216, 235-6, 239-40, 262

Japan 44, 64-5

Jordan 236

Laos 241

Latin America 9, 43, 51, 60, 74, 89, 174, 215, 249, 258, 268

Lebanon 34

Les Saintes 240

Madagascar 242, 262

Madeira 244

Malawi 236

Malaya 236

Malaysia 236

Marie Galante 240

Marshall Islands 245

Martinique 29-31, 34, 36-7, 39-41, 80, 154-5, 173, 194, 196, 221, 240-2, 244, 259, 262, 265-6

Mauritius 262

Mayotte 241

Mexico 43, 233, 268

Middle East 31

Montserrat 21, 25-6, 153-5, 174, 235-7, 240, 262-3

Morocco 18o, 189, 241-2

Netherlands Antilles 9-10, 12-5, 56-8, 61-9, 74-6, 71-104, 112-3, 116-52, 154-5, 157-6o, 162-73, 177-84, 187, 189-93, 199, 201-12, 214, 217-25, 228-31, 237 , 239, 242, 257-61, 264-5, 267-8

Netherlands, Kingdom of the passim New Caledonia 239 New Guinea, see Indonesia New-Netherlands 57 New Zealand 23, 64, 180, 239 Northern Mariana Islands 245 Nouvelle-Calédonie 241

Palestina 236

Panama 43, 144, 177, 245-6, 249 Philippines 43, 45, 70, 245 
Pitcairn Islands 239-40

Polynésie Française 241

Portugal 57

Puerto Rico 9, 11, 19, 42-56, 154-6, 174-5, 194, 197-9, 213-5, 220-3, 232, 237, 239, 245-51, 259, 262, 265

Republic of Palau 245-6

Réunion 29, 32, 39, 41, 173, 241, 244, 259, 262

Russia, see Soviet Union

Saba $57-8,137,201$

Saint-Barthélemy 240

Saint-Domingue, see Haiti

Sandwich Islands 43

Seychelles 262

Singapore 236

South Africa 57, 93, 236, 262

South Georgia \& South Sandwich Islands 239

Soviet Union 24, 43, 249

Spain 43-5, 48, 52, 144, 213, 215, 246

St. Croix 53, 251

St. Eustatius 57-8, 137, 201

St. Helena $239-40$

St.John 53

St. Kitts-Nevis 17, 21, 23, 235-6, 238

St. Lucia 17, 21, 213, 235-6, 262

St. Martin 29-30, 57-8, 121, 127, 129, 134-9, 148, 150-1, 201, 225, 229, 231, 240, 258

St. Pierre-et-Miquelon 241

St. Thomas 53, 248, 250

St. Vincent 17, 21, 235-6

Suriname 9-10, 12-5, 56-69, 71-119, 125, 131-2, 144, 153-5, 157-66, 177-8, 180-9o, 194, 201-2, 204, 207-11, 215, 217-20, 223, 228, 230, 233, 235, 237, 239, 242, $258,260,262,265-6$

Syria 34
Terres Australes et Antarctiques

Françaises 241

territoires associés 33, 241

territoires d'outre-mer 33, 35, 241-3

Tobago, see Trinidad and Tobago

Togo 241

Tokelau 239

Trinidad, see Trinidad and Tobago

Trinidad and Tobago 17, 22, 154-5, 216, 235-6, 239, 244, 258

Tristan da Cunha 239

Tunesia 241-2

Turkey 180, 189

Turks and Caicos Islands 21, 24, 26, $154-5,174,235-7,240,262$

United Kingdom 9-11, 17-29, 31-2, 42-4, 57, 59, 64-5, 68, 70, 96, 174-5, 177, 182, 289

194-5, 199, 213, 216-7, 222-3, 236-40, 244, 262-3

United States 9, 11, 19, 24, 27, 32, 42-56, 59-60, 64, 66-8, 70-2, 85, 89, 122, 143-4, 172-7, 194-5, 197-9, 213-6, 221-3, 232-3, 239-40, 245-51, 262

U.s. Virgin Islands 9, 11, 42-3, 45, 53-6, 59, 154-5, 174, 197-8, 220-2, 239-40, $245,247-8,250-1,262$

Vanuatu 242

Venezuela 6o, 74, 97, 122-3, 129-30, 233, $252,258,268$

Vietnam 89, 241-2

Wake 43

Wallis-et-Futuna 241

Windwards Islands (Dutch) 62,133,190, 201, 203, 205

Zambia 236 


\section{Index of Organisations and Political Parties}

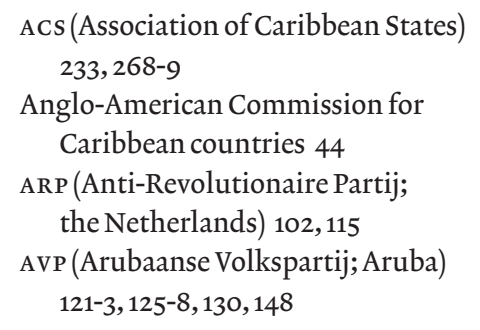

\footnotetext{
Caribbean Commission 245

CARICOM(Caribbean Community) 233, 269

CBI(Caribbean Basin Initiative) 50, 249

$\operatorname{CDA}$ (Christen Democratisch Appèl; the Netherlands) 89, 115, 118-9, 121, 131, 138, 163, 181, 204, 256

CIA (the United States) 259

CPN (Communistische partij; the Netherlands) 64,71
}

D66 (Democraten '66; the Netherlands) 13, 102, 256

Democratic Party (the Netherlands Antilles) 99-100

Democratic Party (St. Martin) 134

Democratic Party (the United States) 45

Ds'7o(Democratisch Socialisten'70; the Netherlands) 188

Eastern Caribbean Federation 21-2

European Union 26, 30, 36, 40-1, 144-5, $156,173,180,192,195-6,222,230,233$, 239, 244, 261-2, 264, 267-8

IMF $147,150,169-71,175,257,260-1$

ктP (Kaum Tani Persatuan Indonesia; Suriname) 102, 112

KVP (Katholieke Volkspartij; the Netherlands) 102
Labour Party (British) 195

Leeward Islands Federation (British)

18, 21, 235

LPF (Lijst Pim Fortuyn; the Netherlands)

118-9

MEP (Movemiento Electoral di Pueblo;

Aruba) 122-5, 128, 130, 148

NAR (Nationale Advies Raad voor

Ontwikkelingssamenwerking;

the Netherlands) 161-2, 167

NPK (Nationale Partij Kombinatie;

Suriname) 103,106

NPR (Partij Nationalistische Republiek;

Suriname) 95

NPS (Nationale Partij Suriname;

Suriname) 93-5, 253

Pan-American conference 74

PCF (Parti Communiste Française) 37,

241-3

PIP (Partido Independentista Puertor-

riqueño; Puerto Rico) 47-8, 52, 249

PNP (Partido Nuevo Progresista; Puerto

Rico) 48, 50-1, 249

PPD (Partido Popular Democrático;

Puerto Rico) 51, 246-7, 249

PPR (Politieke Partij Radicalen; the Netherlands) 102

Progressive Party of Martinique 243

PvdA(Partij van de Arbeid;

the Netherlands) $13-4,73,77,89,97$,

101-2, 115-9, 121, 140, 181, 183, 188,

205, 211, 256

Republican Party (the United States)

$45,50,52$

United Nations 26, 34, 47-8, 54-5, 72, $74,80,84-5,90-1,93,122,238-41,247$ 
VHP (Verenigde Hindostaanse Partij; Suriname) 94-5, 97, 106-7, 109-10, 112-3, 161, 188

vvD (Volkspartij voor Vrijheid en

Democratie; the Netherlands) 13, 89, 111, 118, 121, 140, 142, 188-9, 192, 256
West India Commission 266

West India Royal Commission 19

West India Company 58

West Indian Federation (British) 11, 18-22, 93, 122, 216, 236, 240

Windward Islands Federation (British) 18,235

World Bank 258-9, 262 